Ana Paula de Almeida Muniz

Técnicas de si versus técnicas de poder em Michel Foucault Um diagnóstico do presente

Tese apresentada como requisito parcial para a obtenção do grau de Doutor pelo Programa de PósGraduação em Filosofia do Departamento de Filosofia da PUC-Rio.

Orientadora: Profa. Irley Fernandes Franco 


\title{
Técnicas de si versus técnicas de poder em Michel Foucault Um diagnóstico do presente
}

Tese apresentada como requisito parcial para a obtenção do grau de Doutor pelo Programa de PósGraduação em Filosofia do Departamento de Filosofia do Centro de Teologia e Ciências Humanas da PUC-Rio. Aprovada pela Comissão Examinadora abaixo assinada.

\author{
Profa. Irley Fernandes Franco \\ Orientadora \\ Departamento de Filosofia - PUC-Rio
}

Prof. Paulo Cesar Duque Estrada

Departamento de Filosofia - PUC-Rio

Prof. Henrique Antoun

Universidade Federal do Rio de Janeiro (UFRJ)

Prof. James Bastos Arêas

Universidade do Estado do Rio de Janeiro (UERJ)

Profa. Denise Berruezo Portinari Coordenadora Setorial do Centro de Teologia e Ciências Humanas - PUC-Rio

Rio de Janeiro, 29 de maio de 2015 
Todos os direitos reservados. É proibida a reprodução total ou parcial do trabalho sem autorização da universidade, da autora e da orientadora.

\section{Ana Paula de Almeida Muniz}

Graduou-se em psicologia pela PUC-Rio em 2001. Ingressou neste Programa de Pós-Graduação em 2010. É psicanalista. Trabalhou no Instituto Municipal Philippe Pinel entre 2004 e 2008. Atualmente exerce a clínica e participa de atividades de formação e transmissão da psicanálise.

Ficha Catalográfica

Muniz, Ana Paula de Almeida

"Técnicas de si versus técnicas de poder em Michel Foucault: um diagnóstico do presente" / Ana Paula de Almeida Muniz ; orientadora: Irley Fernandes Franco. 2015.

206 f. ; $30 \mathrm{~cm}$

Tese (doutorado)-Pontifícia Universidade Católica do Rio de Janeiro, Departamento de Filosofia, 2015.

Inclui referências bibliográficas

1. Filosofia - Teses. 2. Subjetivação. 3. Técnicas de si. 4. Estética da existência. I. Franco, Irley Fernandes. II. Pontifícia Universidade Católica do Rio de Janeiro. Departamento de Filosofia. III. Título. 


\section{Agradecimentos}

À Capes e à PUC-Rio, pelos auxílios concedidos, sem os quais este trabalho não poderia ter sido realizado.

A Mary Vanise e a Suzana Neves, pela presença nesse processo e em tantos outros da minha vida. Agradeço infinitamente pela arte da escuta, por sua coragem e seu amor à verdade.

A Camila do Valle, pelo aprendizado, pelas trocas valiosas, pelo exemplo de luta, força e ética pela vida. Agradeço a energia afetiva e efetiva que faz tantas coisas bonitas existirem.

A Henrique Antoun, que torna possível traçar diagnósticos do presente fazendo cintilar saberes sempre a favor de uma ética pela vida. Obrigada pelas terças-feiras que abrilhantam minha trajetória intelectual. Obrigada, principalmente, pela parceria no decorrer deste trabalho, pela amizade e escuta das angústias inevitáveis que irrompem no caminho de quem busca o conhecimento.

A Irley Franco, pelo apoio e amizade de tantos anos, pelas trocas filosóficas e artísticas, pela amizade e estética. Obrigada pelo apoio e pela aposta nas questões desenvolvidas neste trabalho.

Ao professor Paulo César Duque Estrada, pelas aulas, pela ética, pelo legado. 
A meus pais e minhas irmãs, pelo amor, pela aposta em mim, por estarem ao meu lado em todos os momentos.

Aos amigos Andrea Barbosa, Bruno Wagner Santana e Daniele Miranda, pela presença ao longo de todo o processo de escrita desta tese. Agradeço as trocas fundamentais e os momentos felizes e encorajadores. Com vocês, a aventura foi muito mais divertida.

A Thaiana Rodrigues, Cassio Essir, Livia Arnaud e Vanessa Rosa, pelos encontros afetivos, artísticos, culinários e poéticos.

A Bianca Vilhena, pela amizade inspiradora. Obrigada por compartilhar a filosofia, $\mathrm{o}$ afeto e a resistência política.

A Cíntia Chain e Silvia da Silva Costa, pela parceria filosófica-ético-políticaafetiva. Obrigada por todos os encontros.

A Jaqueline Humel Antoun, por todo apoio e amizade, tão importantes nesse processo.

A todos aqueles que fizeram e fazem análise comigo. Obrigada por aguçar minha vontade de estudar, de querer estar junto para transformar as coisas, enfim, pelo amor de transferência.

A Fátima Oliveira Setúbal, pela amizade e pelo exemplo de luta.

A Clarissa Penna e Guto Bellucco, pelas trocas ricas e afetivas nos tantos encontros ético-estéticos.

A Maria Cláudia Canto Cabral, pela amizade e transmissão do cuidado de si em sua prática cotidiana, em nossa prática cotidiana...

A Constança Toledo, Denise Assumpção, Leila Leme e Luiz Eduardo Bonifácio, pela parceria e amizade tão especial. 
A Janete Oliveira e toda a família da Parnaioca, por cada renascimento.

Agradeço toda a atenção prestada pela Edna e pela Dinah e, ainda, a todos os funcionários da PUC-Rio. Vocês são parte de minha trajetória intelectual. Obrigada pelo apoio desde o início. Grata, sempre.

Aos meus felinos Dudu e Cleo, pela companhia carinhosa de tantos anos, todo o meu amor e gratidão. 


\section{Resumo}

Muniz, Ana Paula de Almeida; Franco, Fernandes Irley. Técnicas de si versus técnicas de poder em Michel Foucault: um diagnóstico do presente. Rio de Janeiro, 2015. 206p. Tese de doutorado - Departamento de Filosofia do Centro de Teologia e Ciências Humanas, Pontifícia Universidade Católica do Rio de Janeiro.

Esta tese propõe um “diagnóstico do presente" à luz da noção foucaultiana de sujeito, reposicionando o problema do sujeito diante da constatação da urgência de retomar o tema da ética em nossa época. A pesquisa de Foucault sobre o tema do sujeito resgata a noção grega de epiméleia heautoû - que perdeu importância no campo da filosofia para a de gnôthi seautón -, pela qual elaboramos uma crítica do sujeito, ao mesmo tempo que propomos a abertura do campo da subjetivação, assim como a consideração das técnicas de si, relacionadas à noção de epiméleia heautoû, como estratégia de resistência ao poder capitalista, que, no nosso tempo, opera como um "imperador da ditadura do consumo". Propomos, enfim, uma ética como estética da existência.

\section{Palavras-chave}

Subjetivação; técnicas de si; estética da existência. 


\section{Résumé}

Muniz, Ana Paula de Almeida; Franco, Fernandes Irley (directrice). Techniques de soi versus thecniques de pouvoir en Michel Foucault: un diagnostique du présent. Rio de Janeiro, 2015. 206p. Thèse de doctorat Departamento de Filosofia do Centro de Teologia e Ciências Humanas, Pontifícia Universidade Católica do Rio de Janeiro.

Cette thèse se propose d'un "diagnostic du présent" d'après la notion de sujet élaborée par Michel Foucault, en posant le probléme du sujet devant la constatation de l'urgence d'une revue du thème de l'éthique. La recherche de Foucault sur le thème du sujet remet à l'ordre du jour la notion grecque d'epiméleia heautoû, qui a été remplacé dans le champ philosophique par la notion de gnôthi seautón. On fait, donc, la critique du sujet, au même temps qu'une ouverture du champ de la subjectivité, à la lumière des techniques de soi qui concèrnent à la notion de epiméleia heautoû, dont l'objectif est dessiner une stratégie de résistance au pouvoir capitaliste, qui opère aujourd'hui comme un "empereur de la dictature de la consommation"; c'est-à-dire que cette thèse suggère une éthique comme esthétique d'existence.

\section{Mots-clés}

Subjectivité; techniques de soi; esthétique de l'existence. 


\section{Sumário}

Introdução

1 A questão do conhecimento do sujeito por ele mesmo: ................................18

a retomada da noção de epiméleia heautoû.........................................................18

1.1 A tarefa da filosofia: o diagnóstico da atualidade ........................................22

1.2 A hermenêutica moderna e o sujeito da consciência .................................. 29

1.3 A interpretação na Modernidade: abertura para a produção ................... 40

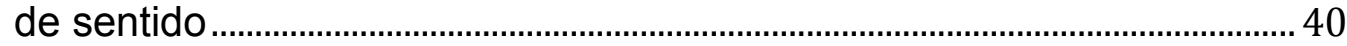

1.4 O homem como homo natura - uma invenção ............................................ 43

1.5 A eliminação do cuidado de si como objeto da preocupação filosófica

1.6 A relação entre o sujeito e a verdade: o niilismo como a interpretação do sujeito moderno ……………………………………………………………….... 51

1.7 A subjetivação antiga no rastro da hermenêutica..........................................54

1.80 sujeito da revolução: uma nova linha de subjetivação na

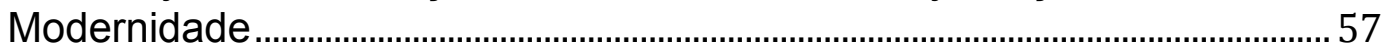

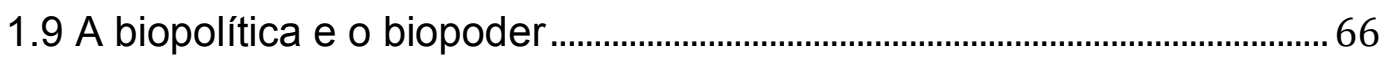

2 A Aufklärung kantiana e o acesso à verdade ................................................... 69

2.1 o sujeito na nossa cultura: um espectador passivo em face dos

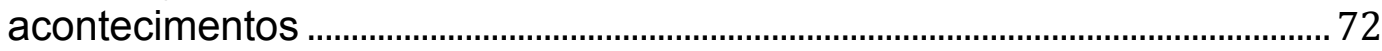

2.2 A abordagem da Antiguidade pelo ponto de vista....................................... 77

do genealogista: para além da questão do método, uma saída............... 77

30 sujeito na Antiguidade era capaz de formular sua verdade: a

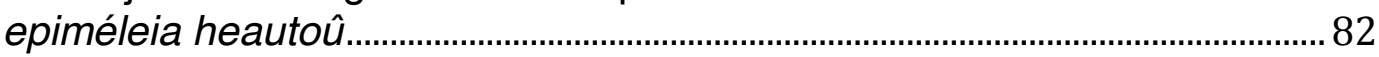

3.10 âmbito da educação como campo de aplicação ...................................... 84

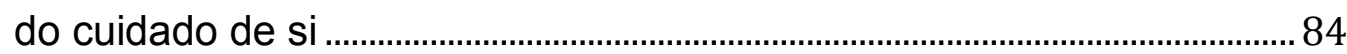

3.1.1 A referência ao diálogo do Alcibíades..................................................... 84

3.2 A prática de si do período clássico à época imperial: algumas transformações............................................................................................................... 89

3.3 A paraskheué: o suporte emocional para a vida ....................................... 95

3.4 A prática de si como uma prática social de conjunto .................................101

3.5 A parrhesía ...........................................................................................................109

3.6 A paramentação estoica ...............................................................................111

3.7 O cuidado de si e o domínio dos prazeres (enkráteia).............................113 
3.8 Uma estética da existência no presente ....................................................114

3.9 O sujeito como salvação de si..........................................................................115

4 A objetivação do sujeito na nossa época: o biopoder versus uma estética de si.

4.1 O cuidado com a formação: a escola .............................................................122

4.2 O cuidado com a saúde: a medicina..............................................................124

$4.3 \mathrm{O}$ cristianismo e a atribuição do sentido de suspeita

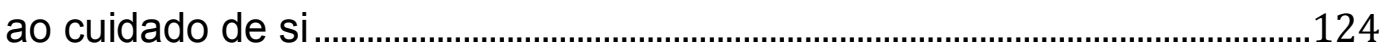

4.4 A salvação de si antiga refletida na Modernidade....................................133

4.5 A epistrophé platônica e metanóia cristã .....................................................135

4.6 Aspectos particulares da prática de si helenística e romana ................140

4.7 Um traço da temática da Modernidade entre os antigos:

o sujeito e a lei

$4.8 \mathrm{O}$ aspecto da utilidade da amizade .............................................................147

4.9 O sujeito e a verdade: o olhar voltado para si ................................................154

4.10 Do cuidado de si à conversão a si................................................................160

4.11 O abuso do poder e o papel do filósofo no Ocidente .............................164

4.12 A influência da pastoral cristã na formação

do indivíduo moderno ..........................................................................................168

4.13 A subjetivação como resistência cultural .................................................172

$4.14 \mathrm{O}$ papel do intelectual na atualidade: o intelectual específico ...........174

$4.15 \mathrm{O}$ corpo científico tem base em uma fisiologia moral da carne.........177

4.16 O sujeito da psicanálise como inventor de si mesmo ............................185

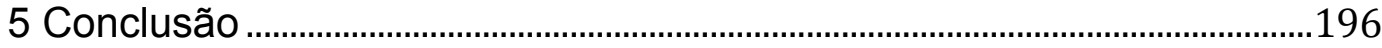

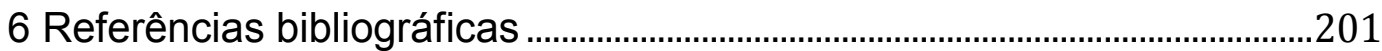


Com Platão se inicia um grande mito ocidental: o de que há antinomia entre saber e poder. Se há o saber, é preciso que ele renuncie ao poder. Onde se encontra saber e ciência em sua verdade pura não pode mais haver poder político. Esse grande mito precisa ser liquidado. Foi esse mito que Nietzsche começou a demolir ao mostrar, em numerosos textos já citados, que, por trás de todo saber, de todo conhecimento, o que está em jogo é uma luta pelo poder. O poder político não está ausente do saber, ele é tramado com o saber.

Foucault 


\section{Introdução}

É preciso não confundir história da filosofia e arqueologia do pensamento. Michel Foucault, Ditos e escritos II

Esta tese se fia naquilo que Foucault denominava "arqueologia do pensamento", pois pretende engendrar uma análise crítica do sujeito, da questão do conhecimento do sujeito por ele mesmo, convencionada pela tradição filosófica, desde os primórdios, a partir da formulação délfica do gnôthi seautón ("conhece-te a ti mesmo"). No curso A hermenêutica do sujeito, deparamos com uma "nova" rota de acesso a essa questão, pela via de outro preceito, o de epiméleia heautô̂ ("cuidado de si"), com o qual Foucault afirma a necessidade de arriscar o levantamento de uma problematização, diante da constatação de que o sujeito de nossa época, formulado pelos critérios do conhecimento com base na fórmula do gnôthi seautón, está fadado à submissão ao poder. Nossa ideia é que uma análise do sujeito por essa perspectiva nos possibilite abrir um campo de pesquisa afinado com aquilo que o Foucault do plano da ética denominou por "estética da existência". Ou seja, nossa proposta visa desenhar um campo de subjetivação que tem como principal preocupação traçar um plano ético de reflexão sobre a existência como uma experiência, individual e de conjunto, capaz de elaborar traços que apontem para uma estética da própria vida.

Até os anos 1980, a noção de sujeito aparece na pesquisa de Foucault como um objeto submetido a um poder absoluto e sem saída. Assim, a problematização da noção de sujeito na nossa época foi articulada à questão do poder entendido dessa forma. Tal análise se encontra nos cursos Em defesa da sociedade, Segurança, território e população, $O$ nascimento da biopolítica e nos livros Vigiar e punir e História da sexualidade I: a vontade de saber. Nessa primeira etapa de sua pesquisa Foucault trata a questão do sujeito de modo bem original: aparecendo objetivado de várias formas, formulado em diversos domínios - os quais ele designou por "focos de experiência" -, o sujeito aparece objetivado pelas experiências da loucura, da doença, da criminalidade e da sexualidade, tão significativas na nossa cultura.

A análise de Foucault sempre priorizou as práticas discursivas e a história das formas de veridicção: 
De fato, parece-me que a análise da formação dos saberes, uma vez que procuramos desenhá-la nessa perspectiva, deve ser feita não tanto como a história do desenvolvimento dos conhecimentos, mas a partir e do ponto de vista da análise das práticas discursivas e da história das formas de veridicção (FOUCAULT, 2010a, p. 41).

É conhecida a importância que ele dá ao que designou em sua trajetória por “jogos de verdade”. No campo da subjetivação, a ideia de jogos de verdade ganha um aspecto original ao tratar a relação do sujeito com a verdade de uma perspectiva dinâmica, quando pressupõe um sujeito ativo capaz de construir virtudes, tal como podemos ver na elaboração do sujeito nos séculos I e II entre os estoicos, cínicos e epicuristas. As virtudes, para eles, eram elaboradas a partir das dificuldades singulares de cada um, no que se refere às paixões de cada indivíduo. Assim, cada indivíduo constituía em torno de si um campo de forças onde traçava para si mesmo uma batalha contra aquilo que poderia se voltar contra si mesmo. Esse grupo de filósofos entendia que a escravidão de si por meio de paixões e vícios era um dos maiores desafios pessoais. Desse modo, a constituição de virtudes se dava em um campo em torno de si, de um desafio pessoal incessante, a partir da ideia de que, ao se olhar de frente para aquilo que mais amedronta, é possível ganhar coragem para seguir a vida. Essa linha de pensamento considera que, se o mundo exterior se apresenta muitas vezes perigoso, as fantasias criadas a partir do medo que, naturalmente, se sente diante desse mundo ameaçador se tornam um material de trabalho no campo da subjetivação que não deve ser dispensado, pois o medo produz influências sobre os comportamentos, muitas vezes se potencializando, a tal ponto que leva o sujeito a uma espécie de fuga da própria vida.

Sendo assim, é de uma perspectiva dinâmica, formulando as ferramentas que lhe pareciam necessárias, de acordo com aquilo que está investigando, que Foucault encontra uma saída para analisar a questão do sujeito, abrindo o campo da subjetivação como um lugar que faz fronteira com o campo do poder. É no retorno aos antigos que é delineada essa outra abordagem, possibilitando o desenho de um outro plano de pesquisa. A veridicção possibilita articular a questão do sujeito de maneira a encontrar eco na nossa época, como pretendemos mostrar no presente trabalho. 
Por essa via, lançando mão da noção foucaultiana de diagnóstico do presente, partimos de uma problematização em torno da questão do sujeito, procurando refletir outros elementos que permeiam as fronteiras da categoria tradicional de sujeito do conhecimento - modelo estabelecido pelo pensamento ocidental. Apoiaremo-nos principalmente em Nietzsche, Freud e Marx, pensadores que, no século XIX, relançam de um modo muito específico linhas interpretativas que abalam a categoria moderna de sujeito do conhecimento. Além do que, por tal categoria encontrar-se ancorada em uma história moral, de saber-poder, como mostra Foucault, reiteramos a necessidade de formular uma crítica, pois, se saber é poder, o sujeito do conhecimento, grosso modo, não tem liberdade de conhecer o que escapa ao campo do poder, onde se encontra instalado, por ser objeto desse campo.

No primeiro capítulo, pretendemos mostrar que a análise da subjetivação de Foucault, a partir do resgate da noção de epiméleia heautoû e de gnôthi seautón, nos remete à questão da interpretação na nossa época, na qual imperam os saberes da ciência em contraposição aos saberes peculiares ao campo da subjetividade. $\mathrm{O}$ sujeito da nossa época, concebido pelo recorte positivista da ciência, vai se formular, vai falar de si, sobretudo, por esses critérios. Hoje, a subjetividade fica reduzida a uma demarcação forjada por um recorte positivista, ou seja, por um ponto de vista exterior ao sujeito.

A pesquisa de Foucault, em cima da questão da subjetivação antiga, nos permite abrir um espaço de crítica ao modelo do sujeito do conhecimento que caracteriza a nossa época. Resgatando elementos no campo da filosofia helenística e romana, Foucault propõe a análise de um modelo de constituição de sujeito que, a partir de determinadas técnicas de si, visava formular um componente ético/estético da existência. Trata-se de uma etho-onto-poiética, dirá Foucault, no sentido de que deparamos com a instituição de sujeitos a partir de um lugar ativo de técnicas de si, uma vez que se partia da ideia de que o sujeito não era dado. $\mathrm{Na}$ nossa época, esse tipo de formulação se apresenta como uma novidade, dado que as questões éticas identificadas ao campo do sujeito são formuladas segundo a aceitação de um modelo de formulações prontas, de toda uma codificação moral supostamente válida para o conjunto social como um todo, com base em uma ideia de um sujeito universal. A nosso ver, esse arranjo deve ser problematizado urgentemente, dada a inquestionável falência desse modelo social. 
Pretendemos mostrar não só o quão atual pode ser uma pesquisa em torno das antigas práticas de si transpostas para a nossa época, mas, mais ainda, que esse gesto de direcionamento do olhar do sujeito para si mesmo, característico do "cuidado de si” na Antiguidade, não chegou a ser totalmente eliminado da história do Ocidente, como pode às vezes parecer, devido ao predomínio do "conhece-te a ti mesmo". Alguns elementos da epiméleia heautoû, do "cuidado de si”, serão reconhecidos no nosso mundo, no cerne de determinados saberes, como no marxismo e na psicanálise.

No segundo capítulo, vamos nos ater a duas noções filosóficas importantes a de Aufklärung, que problematiza a ideia de minoridade, traçada por Kant, e a do ideal ascético, que problematiza a questão do sentido para a vida, desenhada por Nietzsche. Esses autores influenciam a ideia foucaultiana de "diagnóstico do presente", posto que Nietzsche, ao romper com a concepção de tempo como objeto fixo e eterno pautada na tradição filosófica, circunscreve um campo filosófico onde o tempo é apreendido a partir da categoria de "intempestivo". A ideia de Foucault de "atualidade" vai ao encontro dessa categoria nietzschiana, o que nos permite embasar a nossa suspeita de que, para problematizar o nosso tempo, não nos basta empregarmos os nossos olhos modernos. Digamos que eles estão "formatados" para enxergar basicamente aquilo que os dispositivos de poder querem que enxerguemos...

Já o Kant que Foucault resgata agrega o trabalho de um diagnóstico do presente, posto que ele formula uma reflexão sobre o presente como saída (Ausgang) do que ele designa como "estado de minoridade", ou seja, o Kant que engendra o momento atual por meio da diferença, propondo, no lugar de uma época, um éthos. ${ }^{1}$ Essas linhas de pensamento se aproximam das elaborações de Foucault ao nos fornecer instrumentos para tecer uma crítica do sujeito atual a partir de elementos de um campo de subjetivação antigo, como pretendemos mostrar no presente trabalho.

\footnotetext{
${ }^{1} \mathrm{O}$ éthos, para os gregos, é um modo de ser do sujeito que se traduz em seus costumes, seu aspecto, sua maneira de caminhar, a calma com que enfrenta os acontecimentos da vida. Em lugar de tomar a Modernidade como um período e assim distinguir entre "moderno", "pré-moderno" e "pósmoderno", Foucault entende a Modernidade como uma atitude, um éthos, no sentido grego do termo; ou seja, como uma escolha voluntária de uma maneira de pensar e de sentir, de agir e de se conduzir, como marca de pertencimento e como tarefa (CASTRO, 2009, p. 154).
} 
No decorrer da elaboração de nosso texto, deparamos com a necessidade da leitura do célebre livro A sociedade do espetáculo: comentários sobre a sociedade do espetáculo, de Guy Debord. Esse livro, precursor de toda análise crítica da moderna sociedade de consumo, ${ }^{2}$ aparece como chave fundamental para pensarmos as relações do sujeito hoje dentro da concepção do que ele vai chamar de transição do "ser" para o "ter" (DEBORD, 1997, p. 18), ${ }^{3}$ apontando para uma forte adesão dos indivíduos, no que concerne a seu campo de necessidades, aos bens de consumo forjados pelo sistema capitalista. Por essa via, esse livro nos tocou profundamente, especialmente por tratar da ideia do nosso campo social como um conjunto de forças que demanda uma subjetivação voltada para "fora", para o mundo do consumo, onde os sujeitos se formulam como imagens para o outro, para serem estimadas, contempladas, referenciadas pelo outro. Vivemos em um mundo de celebridades, onde a enorme falta de sentido que outrora deu lugar ao ideal ascético recebe hoje o invólucro do "gosto" pela espetacularização da existência.

O terceiro capítulo vai tratar do recorte da subjetivação delineada a partir das práticas de si mesmo helenísticas e romanas, na direção de uma análise da pragmática do sujeito nos primeiros séculos da nossa era, como recorte para refletirmos o tema do sujeito sem nos preocuparmos em criar uma teoria do sujeito. Nesse aspecto, pretendemos mostrar que o si mesmo como objeto de preocupação antiga vai dizer da questão da existência por um ponto de vista estético que, como veremos, aponta necessariamente para uma preocupação com uma ética da vida na qual se pense na subjetivação como um campo de formulação de si e do outro. Essa ética seria no sentido de uma arte de viver relacionada às questões singulares dos sujeitos, que, transposta para o nosso tempo, pode operar como um antídoto contra a anestesia oriunda de um poder que explora infinitamente as forças subjetivas desde que se desenharam os corpos dóceis. Claro que os momentos históricos de que trataremos são distintos, mas pretendemos mostrar que a reflexão desse modo

\footnotetext{
2 "Quanto mais o tempo passa, mais atual se torna esse texto, pois, como disse Jean-Jacques Pauvert, “ele não antecipou maio de 1968, antecipou o século XXI"' (DEBORD, 1997).

3 “A primeira fase da dominação da economia sobre a vida social acarretou, no modo de definir toda realização humana, uma evidente degradação do ser para o ter. A fase atual, em que a vida social está totalmente tomada pelos resultados acumulados da economia, leva a um deslizamento generalizado do ter para o parecer, do qual todo 'ter' efetivo deve extrair seu prestígio imediato e sua função última. Ao mesmo tempo, toda realidade individual tornou-se social, diretamente dependente da força social, moldada por ela. Só lhe é permitido aparecer naquilo que ela não ê" (DEBORD, 1997, p. 18; grifos do autor).
} 
de subjetivação antigo pode nos proporcionar recursos para problematizar as formas de subjetivação hoje.

O quarto capítulo vai tratar de uma relação entre biopoder e ética, tal como pensada pelo viés das práticas de si, ou seja, uma ética voltada para a vida de cada um e de todos, se propondo como uma ética de si mesmo e de conjunto; no caso, uma aposta crítica ao biopoder. Um exemplo atual de uma linha de subjetivação que produz uma crítica ao modelo do biopoder é o modelo da subjetivação da psicanálise, que apresentaremos em breves linhas nessa última parte.

As razões do nosso interesse por essa pesquisa ancoram-se na ideia de que a formulação desse problema, no formato de diagnóstico do presente, como diria Foucault, é pela via do que ele designou de exercício do pensamento, o esboço de uma crítica inadiável, visto o problema do niilismo que atravessa as nossas subjetividades. Esse exercício segue uma orientação ética - em vez de nos contentarmos com essa espécie de fenômeno de anestesia subjetiva presente no nosso mundo, que nos dá em troca um olhar indigente para o nosso si mesmo e para os outros, optamos por nos mexer. 


\section{A questão do conhecimento do sujeito por ele mesmo: a retomada da noção de epiméleia heautoû}

A história da filosofia situa os primórdios da questão do sujeito em sua relação com a verdade na célebre fórmula fundamentada no preceito délfico gnôthi seautón ("conhece-te a ti mesmo"). Foucault busca trabalhar o tema a partir de outro ponto de vista, uma vez que sua trajetória de pensamento apontou para os equívocos que tanto os universais antropológicos quanto a categoria de humanismo produzem quando se instaura uma ideia de natureza humana que sustenta, por sua vez, uma série de privilégios e direitos para alguns, em detrimento de outros.

$\mathrm{O}$ curso A hermenêutica do sujeito, que serve de horizonte à nossa pesquisa de problematização do sujeito, parte do estudo de alguns arqueólogos e historiadores que trata do destaque dado pela história ao gnôthi seautón e da consequente destituição de importância de outro preceito - a epiméleia heautô̂ ("cuidado de si”) -, de um ponto de vista crítico. Tal análise atenta para o fato de que, durante um tempo, o "conhece-te a ti mesmo" esteve subordinado ao "cuidado de si" como uma das formas desse cuidado, que contemplava todo um conjunto de práticas, dentre as quais aparece a formulação do preceito gnôthi seautón. Quando esse preceito entra para o campo da filosofia, toma novos rumos, até chegar à Modernidade, quando passa a obter o aspecto atual, mas isso em um segundo momento.

Foucault atenta para um problema na história do pensamento e formula, portanto, uma análise crítica: o fato de que as ciências humanas aparecem, a partir do século XIX, submetidas a uma dupla obrigação, que configura um enfrentamento: a da hermenêutica, ou exegese - a necessidade de se compreender o sentido escondido por trás dos discursos -, e a da formalização - a imposição de formalização, a exigência de encontrar o sistema, o invariante estrutural, a rede de simultaneidades dos discursos. Foucault observa nessa bifurcação nitidamente paradoxal a linha interpretativa que Marx, Nietzsche e Freud vão traçar. Esses pensadores do século XIX instauraram técnicas interpretativas que têm elementos próprios ao campo da epiméleia heautoû. O primeiro livro de $O$ capital, os textos que compõem $O$ nascimento da tragédia e a Genealogia da moral e a Traumdeutung são atravessados por técnicas interpretativas que abalam o 
pensamento ocidental por restabelecer "hieróglifos", como Marx designou, diante dos nossos olhos modernos. Essas linhas interpretativas vêm nos implicar como sujeitos intérpretes. Como acabamos de nos referir a Marx, vamos recorrer por um instante a um trecho de $O$ capital, em que ele afirmar que:

$\mathrm{Na}$ testa do valor não está escrito o que ele é. O valor converte, antes, todo produto do trabalho num hieróglifo social. Mais tarde, os homens tentam decifrar o sentido desse hieróglifo, desvelar o segredo do seu próprio produto social, pois a determinação dos objetos de uso como valores é seu produto social tanto quanto a linguagem $(2013$, p. 149$){ }^{4}$

Marx tece um pensamento que vai ao encontro do tema do "cuidado de si", no breve recorte que pretendemos fazer aqui, ao mostrar que o aspecto de equivalente universal do dinheiro, ao repercutir nas relações cotidianas da sociedade burguesa em uma direção de desejo de adquiri-lo, acaba encobrindo a ambição pelo poder que emana dele - poder de compra, que, por sua vez, é o poder de transformar qualquer coisa em mercadoria. E, para Marx, como esse processo é um "produto social dos homens", devemos ficar atentos ao destino que a sociedade demanda das forças humanas.

Foucault não mantém sua atenção voltada a uma suposta "sistematicidade formal de uma estrutura nem à pletora interpretativa do significado" (CASTRO, 2009, p. 251). Em vez disso, abre espaço para traçar uma análise histórica da linguagem, a arqueologia, que procura descrever a linguagem no nível dos "enunciados" e das "formações discursivas", considerando-a em sua dispersão, em sua materialidade, priorizando de que modo opera na história. A partir da

\footnotetext{
${ }^{4} \mathrm{~A}$ análise de Foucault, desde As palavras e as coisas, problematiza de modo original a concepção de homem. A célebre frase que marca esse livro, "é um reconforto e um profundo alívio pensar que o Homem não passa de uma invenção recente, uma figura que não tem dois séculos, uma simples dobra do nosso saber, e que desaparecerá, assim que se encontre uma nova forma", coloca a noção de homem como uma invenção do campo do saber. No presente trabalho utilizamos trechos da obra de Marx, Nietzsche, Freud, mesmo que suas análises lancem mão da ideia de homem não deslocada da história das ideias, tal como faz Foucault, a partir de um "pedido de licença", pois o que nos interessa delinear aqui são as correntes interpretativas que esses autores inauguram no século XIX. Por isso, embasando-nos no texto Nietzsche, Freud e Marx, de Foucault, tomamos a liberdade de pinçar alguns trechos de suas obras; sem perder de vista, no entanto, a problematização que Foucault traz da noção de homem, que, para ele, se reduz apenas a uma dobra no campo do saber. O mesmo vale para os capítulos dedicados aos textos sobre a Aufklarüng, de Kant, e A sociedade do espetáculo, de Debord. Também lançamos mão, como citações, de alguns trechos em que aparece o termo, para articular o pensamento desses autores com as reflexões suscitadas pela nossa pesquisa da subjetivação em A hermenêutica do sujeito, articuladas às questões referentes à subjetividade na nossa época.
} 
perspectiva pela qual Foucault desenha dispositivos, sempre atento às práticas, as práticas discursivas são instaladas no campo das práticas discursivas em geral, onde estão situadas as práticas não discursivas. A atenção se volta para o uso da linguagem, que Foucault designa como "discurso", "práticas discursivas", pois sua preocupação extrapola a hipótese de um ser da linguagem e se concentra no aspecto ético. Interessam-lhe as práticas pelas quais o poder opera, daí a ideia de "práticas éticas". Segundo Castro:

A relação entre o discursivo e o não discursivo haverá de se converter, desse modo, em uma via de acesso à análise histórica dos usos da linguagem. Para expressá-lo de algum modo, a temática do "ser da linguagem" é substituída pela temática de "o que fazemos com a linguagem". A problemática da linguagem, em Foucault, vai, assim, do "ser da linguagem" ao "uso da linguagem", às "práticas discursivas". Nesse percurso, Foucault passará da consideração da incompatibilidade entre o "ser da linguagem" e o "ser do homem" à reflexão sobre o uso das práticas discursivas como formadoras de subjetividade (2009, p. 251).

Por essa via, Foucault concebe as linhas interpretativas traçadas por Nietzsche, Freud e Marx, no que tange à ideia de interpretação na Modernidade, sem se ater à questão da estrutura ou do significado. As linhas interpretativas lançadas por esses pensadores interessam-lhe pela abertura que produzem no campo do poder, pois se apresentam como vetores voltados para uma inflexão na direção tanto do indivíduo quanto da sociedade, no sentido de uma preocupação com questões da existência - elementos de preocupação do campo da epiméleia heautoû. O estudo do "cuidado de si", que pretendemos fazer a partir de um mergulho no curso de 1982, trabalha a partir do resgate de um modelo de formação de subjetividade que privilegiava um cultivo de si em meio ao conjunto de demandas sociais que (guardadas as devidas proporções, pois se trata de um modelo antigo) demonstra que a subjetivação pode ser entendida como a formação de um campo de forças em meio a um campo de forças mais amplo - o campo social. Uma atividade que Foucault chama de subjetivação pode servir como tática fundamental para potencializar a vida, tanto no sentido individual quanto coletivo, a partir da criação de virtudes em uma direção de resistência ao poder instituído - na nossa época, o poder capitalista. Recortamos mais uma citação de Marx, desta vez dos Manuscritos econômico-filosóficos, para ilustrar o curso do pensamento que procuramos traçar aqui: 
Pressupondo o homem enquanto homem e seu comportamento com o mundo enquanto [comportamento] humano, tu só podes trocar amor por amor, confiança por confiança etc. Se tu quiseres fruir da arte, tens de ser uma pessoa artisticamente cultivada; se queres exercer influência sobre outros seres humanos, tu tens de ser um ser humano que atue efetivamente sobre os outros de modo estimulante e encorajador. Cada uma de tuas relações com os homens e com a natureza tem de ser uma externação (Äusserung) determinada de tua vida individual efetiva correspondente ao objeto de tua vontade. Se tu amas sem despertar amor recíproco, se mediante tua externação de vida (Lebensäusserung) como homem amante não te tornas homem amado, então teu amor é impotente, é uma infelicidade (MARX, 2004, p. 161; grifos do autor).

Reconhecemos na citação acima alguns traços do que encontramos delineado pelos antigos como a ideia de cultivo de si. Se pensarmos que há várias formas de apreensão do mundo - pelos sentidos, pelo desejo, pelas paixões, pelo querer, pela arte, por diversas formas -, há, portanto, várias maneiras de captura do mundo, inclusive os modos pelos quais podemos formular o saber como um dos elementos da vida, instrumento decisivo, principalmente porque, como mostra Marx, ele surge no mundo do trabalho (MARX, 2013, p. 32). Todos esses elementos ganham lugar em uma pesquisa sobre o tema do sujeito que considere as maneiras pelas quais os sujeitos se constituíram em diferentes momentos históricos. Por essa via pretendemos propor uma exploração do campo de possibilidades do pensamento sobre a questão do sujeito que não se atenha a elementos restritos ao campo de saber, que delineou o plano do sujeito tal como concebemos hoje, ou seja, a partir da categoria de sujeito do conhecimento.

O prevalecimento do "conhece-te a ti mesmo" em relação ao "cuidado de si" é analisado neste trabalho como um problema ao qual se deve voltar a atenção, principalmente diante do advento da objetivação do sujeito. A questão da objetivação do sujeito tem relação com o que Foucault denominou "biopoder", que caracteriza o domínio do poder que, em nome do cuidado pela vida dos indivíduos, os manipula a partir de instâncias legitimadas e responsáveis pela vida das pessoas, como o Estado, por exemplo.

Nesse sentido, até os anos 1980 Foucault problematiza a subjetivação pelos modos de objetivação, ou seja, como objeto que se forma em uma relação de podersaber, o que mostra que a subjetivação e a objetivação podem se encontrar diretamente relacionadas. Essa ideia vai ao encontro da perspectiva dinâmica pela 
qual Foucault fabrica os conceitos com os quais trabalha. Na sua esteira, nossa visão sobre o sujeito não vai se orientar por qualquer formalismo ou empirismo, mas sim pela ótica das batalhas, lutas e disputas, nas quais os saberes em jogo se afiguram objetos, como, por exemplo, determinados modos de subjetivação. Assim, pretendemos tomar a noção de sujeito deslocada de seus termos tradicionais, apostando na ideia de que, na história, formam-se sujeitos, em meio a outras formações, a partir dos acontecimentos; para problematizar o tema do sujeito hoje a partir da noção antiga de epiméleia heautoû, à qual a tradição do pensamento filosófico não conferiu o peso devido.

\title{
1.1 A tarefa da filosofia: o diagnóstico da atualidade
}

A atividade filosófica de Foucault se serve da categoria de "acontecimento" para diagnosticar a atualidade - categoria chave no seu pensamento, tendo sido reformulada em vários pontos de sua trajetória, dadas as significativas transformações que sofreu desde As palavras e as coisas até a História da sexualidade. No Vocabulário de Foucault encontramos uma descrição que indica a abertura, na obra do filósofo, para algumas transformações às quais pretendemos aludir nesta tese:

\begin{abstract}
A tarefa da filosofia consiste em diagnosticar o que acontece, a atualidade. Como ele [Foucault] mesmo observa, em L'Ordre du discours, trata-se de uma categoria paradoxal, que coloca problemas "temíveis" e que foi "raramente levada em consideração pelos filósofos". Em um primeiro momento, podem-se distinguir dois sentidos do termo: o acontecimento como novidade ou diferença e o acontecimento como prática histórica. No primeiro sentido, Foucault fala de "acontecimento arqueológico"; no segundo, por exemplo, de "acontecimento discursivo". O primeiro quer dar conta da novidade histórica; o segundo, da regularidade histórica das práticas (objeto da descrição arqueológica). Existe claramente uma relação entre esses dois sentidos: as novidades instauram novas formas de regularidade (Castro, 2009, p. 24).
\end{abstract}

A noção de acontecimento é complexa, o que nos leva a ficar atentos para não dispor os acontecimentos em um mesmo nível, lembrando sempre que são múltiplos, existem em várias camadas, o que faz com que alcancem lugares diferentes uns dos outros. Além disso, é importante perceber que cada acontecimento vai se dar no seu tempo, associando-se uns aos outros, produzindo os mais diversos efeitos. Nas palavras de Foucault: 
O problema é, ao mesmo tempo, distinguir os acontecimentos, diferenciar as redes e os níveis aos quais eles pertencem e reconstituir os fios que os religam e os fazem gerar-se uns a partir dos outros. Daí a recusa das análises que se referem ao campo simbólico ou ao domínio das estruturas significantes; e o recurso às análises que se fazem em termos de genealogia de relações de forças, de desenvolvimentos estratégicos, de táticas. Penso que aquilo a que se deva referir não é ao grande modelo da língua e dos signos, mas da guerra e da batalha. A historicidade que nos arrebata e nos determina é belicosa; ela não é de linguagem. Relação de poder, não de sentido. A história não tem sentido, o que não quer dizer que ela seja absurda ou incoerente. Ela é, ao contrário, inteligível e deve poder ser analisada até o seu menor detalhe: mas segundo a inteligibilidade das lutas, das estratégias e das táticas (FOUCAULT, 2014b, p. 18).

Para Foucault, tanto a dialética, como lógica de contradição, quanto a semiótica, como estrutura da comunicação, não são capazes de dar conta do que seria a inteligibilidade própria aos confrontos. $\mathrm{Na}$ sua perspectiva, a dialética seria uma espécie lógica de esquiva, na qual o caráter de contingência e abertura intrínseco dos confrontos acaba sendo diminuído "sob o esqueleto hegeliano", e a semiologia acaba sendo um modo pelo qual se pretende esquivar do caráter "violento, sangreto, mortal, rebaixando-a sobre a forma apaziguada e platônica da linguagem e do diálogo" (FOUCAULT, 2014b, p. 18).

$\mathrm{Na}$ esteira de Nietzsche, Foucault propõe uma espécie de reparo na ideia de que a tarefa fundamental da filosofia seria ir ao encalço de uma verdade intemporal. Para ele, a filosofia diz de uma atitude filosófica: a formação de diagnósticos voltados para os acontecimentos, nesse movimento incessante de instauração de regularidades, toda vez que se funda uma novidade. Essa linha de pensamento, na qual se propõe como tarefa filosófica a formação de diagnósticos referentes à atualidade, segue uma perspectiva dinâmica que se imprime na concepção dos "jogos de verdade", noção que aparece na introdução do segundo volume da História da sexualidade II: o uso dos prazeres. Esse livro foi escrito depois de um intervalo de oito anos entre o primeiro e o segundo volume dessa série, e Foucault se dedicará inicialmente a descrever uma espécie de justificativa a respeito do retorno para a Antiguidade. Sendo assim, ele discorre sobre as modificações teóricas efetuadas nessa etapa de seu trabalho, com vistas a tratar o tema do sujeito, e, nesse contexto, acabamos sendo gratificados com um sobrevoo teórico preciso acerca da sua obra como um todo. 
As análises da subjetivação, na visão de Foucault, apontam para o campo do poder como lugar capaz de legitimar, ao mesmo tempo, sujeitos do conhecimento e sujeitos na forma de objetos do conhecimento. Essa perspectiva leva em conta as maneiras pelas quais o ser humano vai se inscrever por essa via da objetivação/subjetivação na nossa cultura, e é nessa direção de trabalho que Foucault vai traça o objetivo principal de sua obra. Em suas palavras:

Meu trabalho lidou com três modos de objetivação que transformam os seres humanos em sujeitos. O primeiro são os modos da investigação, que tenta atingir o estatuto de ciência, como, por exemplo, a objetivação do sujeito do discurso na grammaire générale, na filosofia e na linguística. Ou, ainda, a objetivação do sujeito produtivo, do sujeito que trabalha, na análise das riquezas e na economia. $\mathrm{Ou}$, um terceiro exemplo, a objetivação do simples fato de estar vivo na história natural ou na biologia. Na segunda parte do meu trabalho, estudei a objetivação do sujeito naquilo que chamarei de "práticas divisoras". O sujeito é dividido no seu interior e em relação aos outros. Esse processo o objetiva. Exemplos: o louco e o são, o doente e o sadio, os criminosos e os "bons meninos" (FOUCAULT apud DREYFUS e RABINOW, 1995, p. 273).

Diante desse quadro, podemos entender que os discursos legitimados como as verdades próprias a cada época serão produzidos em um campo de saber-poder que constitui os objetos e os sujeitos uns em relação aos outros.

É conhecido o debate sobre a questão de se, no momento em que Foucault escreve a Arqueologia do saber, ele tinha intenção de fixar um método. Nessa ocasião, ele afirma que o livro de forma alguma desenha uma metodologia, pois seu trabalho se orienta em uma perspectiva inventiva que engendra tanto os domínios dos objetos que pretende pesquisar quanto as ferramentas por ele forjadas, como faz questão de mostrar, no momento exato em que está trabalhando. Observe-se o caráter criativo e original de Foucault quando afirma criar as ferramentas de pesquisa no momento exato em que está trabalhando (FOUCAULT, 2006c, p. 229). Essa ideia encontra-se relacionada ao modo pelo qual entendemos a noção de tempo sob a ótica desse pensador. Na esteira de Nietzsche, Foucault entende o tempo pela noção de atualidade, diferenciando-se da tradição filosófica, que concebe o tempo como objeto fixo e eterno. Com Foucault, podemos conceber a noção de tempo como tempo de criação. Assim, a Arqueologia do saber não afirma um método, mas sim um estilo. Por essa via, Foucault se distancia do lugar de um estruturalista, já que é conhecida a preocupação dos estruturalistas em circunscrever um método 
universalmente válido no trato de objetos distintos. Longe de se preocupar em encontrar um método capaz de ligar objetos tão diferentes, tais como "linguagem, os discursos literários, os relatos míticos, a iconografia, a arquitetura" (FOUCAULT, 2006c, p. 229), Foucault vai se ocupar de dar contornos a esse campo de interação entre poder e saber.

Poder e saber, verdade e poder formam a linha de problematização traçada por Foucault. E sua atenção se volta para os efeitos de verdade que a sociedade ocidental, ou melhor, a sociedade mundial não cessa de produzir (FOUCAULT, 2006c, p. 229). Se o termo "verdade" carrega considerável peso histórico no campo da filosofia, não poderemos abdicar de circunscrevê-lo nesta tese pela linha traçada pelo pensamento de Foucault, no sentido de mapear as fronteiras que estabelecem domínios que, por sua vez, organizam dispositivos de poder. Por exemplo, os dispositivos de individualização (dispositivos de subjetividade) desenhados com o advento da reorganização do sacramento da confissão, a partir do século XVI, ou a instituição do hospício, que vai produzir o louco como doente mental (dispositivo de saber) (MACHADO, 1982, p. 197). Segundo Castro, Foucault fala de dispositivos disciplinares, dispositivo carcerário, dispositivos de poder, dispositivos de saber, dispositivo de sexualidade, dispositivo de aliança, dispositivo de subjetividade, dispositivo de verdade etc. (CASTRO, 2009, p. 124). Vemos, assim, que as articulações múltiplas e complexas de saber e poder engendram verdades que podem aparecer das mais variadas formas, produzindo os mais diversos efeitos. O pesquisador voltado para as estratégias presentes em qualquer domínio vai atentar para desenhar as formas pelas quais a verdade esteja operando. Nas palavras de Foucault:

Não se trata de liberar a verdade de todo o sistema de poder - seria uma quimera, já que a verdade é, ela própria, poder -, mas separar o poder da verdade das formas de hegemonia (sociais, econômicas, culturais), no interior das quais, no momento, ela funciona. A questão política, em suma, não é o erro, a ilusão, a consciência alienada ou a ideologia; é a própria verdade. Daí a importância de Nietzsche (FOUCAULT, 2014b, p. 34; grifo meu).

Foucault aponta para a urgência em nos desprendermos dos grandes temas do sujeito do conhecimento, e isso pode ser viável a partir da filosofia de Nietzsche. A pesquisa foucaultiana das práticas de si inspira-se claramente nesse pensador. Foucault abre um campo de pesquisa atento à questão da verdade no Ocidente, 
engendrando análises que têm como pano de fundo a questão de como a verdadeacontecimento vai subsistir no Ocidente. Para Castro:

Pois bem, a propósito do que se pode denominar globalização da verdadedemonstração, Foucault quer mostrar como a verdade-acontecimento permaneceu no Ocidente. Esse é o caso das formas jurídicas e das práticas médicas, desde Hipócrates, até o século XVIII. Segundo Foucault, na história das ciências empíricas, dois processos levaram à transformação da verdadeacontecimento em verdade-demonstração. Por um lado, o procedimento político da "investigação". Por outro, um procedimento inverso, os procedimentos de "rarefação" (raréfaction) dos sujeitos que podem conhecer a verdade (CASTRO, 2009, p. 124).

Podemos visualizar, na obra de Foucault, uma análise do tema do sujeito em três grandes momentos: um primeiro, quando trata das epistemes (arqueologia), um segundo, quando concebe a noção de dispositivo (genealogia), e um terceiro, que será o recortado pelo nosso estudo - o momento em que se volta para as práticas de si antigas (ética).

A pesquisa foucaultiana dos modos de subjetivação passou por transformações de estilo, objeto e metodologia desde quando se desloca do problema das epistemes para o dispositivo e, por fim, para as práticas de si mesmo. Foucault toma o corpo como referência principal de sua observação, não por uma via empírica, o que torna a sua filosofia completamente original, pois, para ele, não se trata de observar "o sujeito", mas sim de constituí-lo. A pesquisa da sexualidade em torno do tema do corpo dócil e das práticas de confissão mostra que os elementos do cuidado moderno se constituem a partir dessa relação de docilidadeutilidade instaurada por um olhar externo, campo dos saberes próprios dos especialistas, que, por sua vez, vão dizer do que os indivíduos sofrem. Ou seja, deparamos com um processo que é de subjetivação, ao mesmo tempo em que é de objetivação. É com base nesse modelo corporal, que articula uma série de interesses voltados aos termos de uma utilidade, que vai se organizar toda uma série de saberes sobre os indivíduos e seu sofrimento.

Vale lembrar aqui do que Foucault descreve sobre "as disciplinas" em Vigiar e punir, ao expor o processo que se exerce ininterruptamente sobre as forças dos indivíduos no engendramento das relações de docilidade-utilidade características do corpo na Modernidade. Segundo Foucault: 
Nesses exemplos de docilidade, em que o século XVIII teve tanto interesse, o que há de tão novo? Não é a primeira vez, certamente, que o corpo é objeto de investimentos tão imperiosos e urgentes; em qualquer sociedade, o corpo está preso no interior de poderes muito apertados, que lhe impõem limitações, proibições ou obrigações. Muitas coisas, entretanto, são novas nessas técnicas. A escala, em primeiro lugar, do controle: não se trata de cuidar do corpo, em massa, grosso modo, como se fosse uma unidade indissociável, mas de trabalhá-lo detalhadamente; de exercer sobre ele uma coerção sem folga, de mantê-lo ao nível mesmo da mecânica - movimentos, gestos, atitudes, rapidez: poder infinitesimal sobre o corpo ativo. O objeto, em seguida, do controle: não, ou não mais, os elementos significativos do comportamento ou a linguagem do corpo, mas a economia, a eficácia dos movimentos, sua organização interna; a coação se faz mais sobre as forças que sobre os sinais; a única cerimônia que realmente importa é a do exercício. A modalidade enfim: implica uma coerção ininterrupta, constante, que vela sobre os processos da atividade mais que sobre seu resultado e se exerce de acordo com uma codificação que esquadrinha ao máximo o tempo, o espaço, os movimentos (FOUCAULT, 2002b, p. 126).

Vemos assim figurar um corpo-máquina voltado a atender a demanda social de produção própria do poder capitalista. Se o nosso mundo se caracteriza pela existência de uma máquina, dentro da totalidade social, que faz com que a política seja a do poder capitalista, que engendra os saberes pertinentes às instituições - que vão regular, por sua vez, as forças, visando a sua própria sobrevivência, a despeito daqueles pelos quais elas são responsáveis; e se o Estado é uma forma necessária do capitalismo, estando amarrado a uma forma política, não basta querer transformá-lo e ponto, pois ele está ancorado nas formas de sociabilidade capitalistas. E, se, na sociedade capitalista, as coisas são moldadas para serem transformadas em mercadoria, tudo vai ganhar a forma de mercadoria: educação, saúde, alimentação, estética, e também o trabalhador, que vai ser remunerado pelo valor de mercado.

Se o trabalho no capitalismo é mercadoria e as pessoas são exploradas, faz-se urgente efetuar uma crítica a esse modo de olhar para a vida que coloca tudo na forma da mercadoria. Ou seja, as instituições legitimadas para cuidar dos indivíduos no capitalismo vão operar a partir de uma ética relacionada essencialmente aos interesses de mercado.

Diante disso, nesse espaço aberto de crítica, pretendemos refletir sobre que elementos podem ser formulados para servir como resistência a esse tipo de poder. Interessa-nos traçar uma linha de pensamento em cima da ideia clássica marxista de que o poder imperial da nossa época, o capitalismo, talha as formas de 
sociabilidade. Se Marx delineou em sua obra a ideia de transformação das relações capitalistas, nós vamos nos contentar aqui em puxar um fio desse novelo, extremamente enodado, para começar a tecer o nosso texto. Não visamos percorrer de modo algum a obra desse autor, mas será inevitável cruzar com algumas de suas ideias em determinados pontos deste trabalho, pois Foucault o cita em momentos cruciais de suas exposições sobre a questão do sujeito, como teremos a chance de mostrar.

Diagnosticamos um mundo extremamente explorado, onde prevalece certo senso comum que acredita que as mudanças devem vir de cima para baixo, por meio de medidas políticas advindas do Estado. Um mundo repleto de insatisfação, no qual as forças se voltam para um sentimento constante de indignação esvaziada, posto que geralmente ausente de referenciais teóricos. Nossa proposta é pensar que essas mesmas forças podem ser trabalhadas no sentido de se voltarem para a ideia da necessidade de se pensar a formação de um campo de subjetivação que, como pretendemos mostrar, pode acabar repercutindo em transformações, não só no que diz respeito ao aspecto individual da vida das pessoas, mas também nas relações interpessoais estabelecidas no campo social. Essa ideia será tratada sob aquilo que os antigos designaram por técnicas de existência e que pretendemos transpor para o nosso mundo. Diante da dimensão das lutas que ocorrem, pelos indivíduos maciçamente explorados e, ao mesmo tempo, anestesiados pelo sistema - nesse circuito perverso no qual quanto mais anestesiados mais explorados -, entendemos que as lutas vão depender das formas, da ordem, das circunstâncias, das estruturas das relações que o nosso mundo apresenta. Por isso, se o Estado e a política são elementos fundamentais dessa manutenção da ordem de exploração existente, é urgente lançar uma reflexão que extrapole as fronteiras desse produto do capital que é a política tal como se configura hoje.

Perante a constatação do fracasso da ideia de uma sociedade organizada e mantida em bases estáveis com o projeto civilizatório que se desenhou até o momento, orientadas por instâncias legitimadas pelo poder, a subjetivação pode se tornar uma maneira de pensar as relações sociais por um prisma ético que fabrique novas ferramentas para mudar as coisas, para que possamos, ao menos, dar forma às forças de resistência.

A nosso ver, falar sobre a ideia de si mesmo a partir de um espaço de constituição de si nos remete a uma conduta ética, pois ultrapassa o tratamento dado 
à existência na nossa época, que prioriza as noções de saúde e de doença, elementos de preocupação do campo político-social que acabaram dando lugar ao biopoder. Não que saúde e doença não tenham que ser elementos de preocupação do campo social, a questão é que se tornaram característicos de um poder biotécnico, que distingue a sociedade ocidental. Dreyfus e Rabinow apresentam uma definição esclarecedora do que Foucault define como biopoder:

[Foucault] isola e identifica a difusa organização de nossa sociedade como "poder biotécnico". Biopoder é o crescente ordenamento em todas as esferas sob o pretexto de desenvolver o bem-estar dos indivíduos e das populações. Para o genealogista, essa ordem se revela como sendo uma estratégia, sem ninguém a dirigi-la, e todos cada vez mais emaranhados nela, que tem como única finalidade o aumento da ordem e do próprio poder (DREYFUS e RABINOW, 1995, p. XXVI; grifo meu).

O corpo como elemento do biopoder, outrora ordenado pela pastoral cristã, acaba despotencializado de suas forças, sendo cada vez mais mantido sob o domínio desse poder indefinido, como aponta Dreyfus e Rabinow. Tais forças engendram dispositivos de poder que geram uma série de efeitos sobre os indivíduos. Para lançar alguma luz em direção ao campo do poder, buscaremos refletir sobre uma atitude de resistência. Interroguemos alguns aspectos que definem o sujeito da consciência - ele pode resistir ao poder?

\subsection{A hermenêutica moderna e o sujeito da consciência}

O homem, o animal mais corajoso e mais habituado ao sofrimento, não nega em si o sofrer, ele o deseja, ele o procura inclusive, desde que lhe seja mostrado um sentido, um para quê no sofrimento. A falta de sentido do sofrer, não o sofrer, era a maldição que até então se estendia sobre a humanidade - e o ideal ascético lhe ofereceu um sentido! Foi até agora o único sentido; qualquer sentido é melhor que nenhum; o ideal ascético foi até o momento, de toda maneira, o faute de mieux [mal menor] par excellence. Nele o sofrimento era interpretado; a monstruosa lacuna parecia preenchida; a porta se fechava para todo niilismo suicida. A interpretação - não há dúvida - trouxe consigo novo sofrimento, mais profundo, mais íntimo, mais venenoso e nocivo à vida: colocou todo sofrimento sob a perspectiva da culpa.

Nietzsche, Genealogia da moral 
Uma das razões do nosso interesse, neste trabalho, tem como pano de fundo alguns anos de reflexão a partir de uma prática em psicanálise, tanto na esfera clínica quanto institucional, na qual pudemos nos confrontar com alguns aspectos referentes aos modos objetivantes do sujeito, dos quais a ciência, hoje, lança mão. A intervenção do psicanalista, principalmente no que diz respeito ao âmbito institucional, convoca para uma implicação dos sujeitos com seu sofrimento e, desse modo, esbarra nos discursos medicalizantes provenientes das promessas dos laboratórios farmacêuticos, comprometidos em tamponar o sofrimento dos indivíduos, atribuindo à esfera biológica uma capacidade de alcançar de maneira calculada e eficiente a esfera psíquica. Nessa direção, delineia-se um campo terapêutico onde são produzidos saberes a partir da concepção de um sujeito experimental, que funcionaria como base das terapias cognitivas pautadas na ideia de estímulo-resposta.

A psicanálise, com seu modo complexo de apreender o sujeito, que, no seu campo, se designa como o sujeito do inconsciente, fica sendo vista como uma técnica ultrapassada diante dos avanços da ciência, como se, por não ter seus critérios pautados pelos fundamentos científicos, ela não tivesse acompanhado os avanços próprios do nosso tempo. Não é nossa proposta aprofundar tal discussão no escopo desta tese e, se a levantamos brevemente, o fizemos para poder, agora sim, apresentar as verdadeiras razões do nosso interesse em situar a questão do sujeito e de uma ética em uma pesquisa concentrada em alguns pontos que Foucault circunscreve quando se volta para o tema da ética. Nossa prática mostra que problematizar o sujeito da nossa época partindo das questões que giram em torno do sujeito da ciência, ou seja, aquele reduzido ao saber delineado pela ciência, acaba por limitar a noção de sujeito ao campo do poder - poder biotécnico (DREYFUS e RABINOW, 1995, p. XXVI).

Esse problema, por sua vez, esbarra no que o campo filosófico designou como niilismo - ou seja, no problema da falta de sentido que advém do advento da morte de Deus, que instaura a Modernidade. Tal aproximação se dá em algum nível porque a moral, que teve tanta força na construção da nossa civilização, permance em vigor no âmbito das relações humanas, tanto no nível jurídico como nas relações que se espelham a partir desse conjunto de códigos nos quais as relações humanas acabam por se sustentar. Esse modelo acaba gerando uma série de problemas, já que as leis que privilegiam determinadas classes sociais deixam as mais 
desfavorecidas funcionarem a partir de outros códigos, códigos esses que as elites vão recodificar de acordo com seus interesses. Esses modos de funcionamento não relançam uma ética e fazem com que as mazelas sociais sejam apreendidas formalmente por uma via de mão única, ou seja, de acordo com os códigos estabelecidos pelas classes privilegiadas.

Diante desse problema do poder que aparta as classes sociais, os territórios, os indivíduos pertencentes a determinado grupo ou outro, alguns vetores de pesquisa se colocam, fazendo com que nos movamos no território da filosofia em busca de lançar em torno do tema do sujeito algumas linhas de pensamento relacionadas à questão da ética na nossa sociedade. Isso porque uma reflexão sobre a ética encontra-se hoje bastante comprometida em vários aspectos, já que nos encontramos em um mundo capitalista onde as leis que regem as relações humanas são as leis de mercado. Assim, o fato de pensar uma ética parece ser um modo de resgatar algum campo possível de reflexão que nos permita, por meio do que Foucault denominou por exercício do pensamento, nos constituirmos como sujeitos, afinal. Mesmo porque o que as análises de Foucault até os anos 1980 ensinam é que, às voltas com as malhas do poder, somos incessantemente objetivados enquanto seres humanos, tendo as nossas forças capturadas para a manutenção desse mesmo poder. Nesse sentido, o interesse de Foucault pelas técnicas de si antigas reside no fato de que apresentam, longe de uma espécie de saída miraculosa, um gesto do indivíduo de inflexão na direção de si mesmo, para tornar possível dar forma às forças de resistência que irrompem no aparato social, pois voltar o olhar para si próprio, no nosso mundo, consiste em um gesto de resistência. Resistência que se dá como um conjunto de forças provenientes do pensamento, quando o indivíduo enfrenta os saberes legitimados para dizer quem somos nós, o que devemos desejar e como devemos nos conduzir. ${ }^{5}$

Na pesquisa de mestrado, com base no livro História da sexualidade II: o uso dos prazeres, estudamos a questão grega da temperança, que se instaurava por determinadas técnicas de $\mathrm{si}^{6}{ }^{6}$ desmistificando a ideia, tão amplamente difundida, de que o sujeito constituído pela moral que conhecemos hoje teria sido delineado pela

\footnotetext{
${ }^{5}$ Ideia desenvolvida em torno do tema das disciplinas e do exame, de que trataremos em seguida. ${ }^{6} \mathrm{Na}$ dissertação, fizemos um apanhado sobre essas técnicas de si, apontando, com base no estudo de História da sexualidade II: o uso dos prazeres, que, na Grécia, o sujeito não se dava simplesmente a partir de um contorno moral. Ele se instaurava em uma relação consigo mesmo e com a pólis, buscando se apresentar como um sujeito temperante, capaz de possuir uma vida bela.
} 
moral cristã. Nesse trabalho, foi possível conhecer alguns elementos do modelo de sujeito que se instaurou com a prática grega da temperança, o que nos levou a entender que determinados traços gregos se apresentam imiscuidos nos nossos modos de subjetividade hoje. Com isso, entendemos que não houve uma ruptura total de determinados traços do sujeito grego com a emergência de uma moral delineada no cristianismo. Alguns aspectos das técnicas de si que se voltavam para a constituição de um sujeito temperante vão sendo transformados, mas não se excluem por completo dos modos de subjetivação que se constituíram entre o que se convencionou como cultura greco-latina. Esse é um dos caminhos que desperta o interesse de Foucault pelo resgate da formulação grega de epiméleia heautoû, noção pela qual pretendemos, portanto, nos orientar.

Por ora, para fins deste trabalho, vamos nos ater a colher alguns pontos, com o objetivo principal de tratar de uma reflexão sobre o que vamos chamar de uma ética de si, baseada na ideia de ética do sujeito, a partir da análise da subjetivação traçada por Foucault. Atentos em não cair em uma pesquisa abstrata de um sujeito que possa ser concebido como universal, vale lembrar que, no nosso mundo, deparamos com um sujeito que se constitui a partir de um aparato social que se sustenta nas leis capitalistas de mercado, que regem, por sua vez, os interesses do campo social, político e moral. Faz-se urgente traçar uma reflexão voltada para o delineamento de uma ética, pois as formas de sociabilidade capitalistas vão priorizar uma ética voltada para os interesses do mercado. Esta pesquisa não tem a pretensão de propor o que seria uma ética no nosso tempo; propõe, sim, a abertura de um espaço de discussão, de problematização, como diria Foucault. E por que não traçar algumas linhas que problematizem a questão do sujeito relacionado a uma ética possível hoje no âmbito acadêmico, principalmente por se tratar de uma tese no Departamento de Filosofia, espaço em que cabe uma reflexão ética?

Se a filosofia e a psicologia fazem fronteira, e se acreditamos em uma espécie de olhar atento às fronteiras delineadas nos diversos campos de saberes, tal como Foucault ensina, entendemos ser importante resgatarmos algumas reflexões que possibilitem lançar uma questão em torno do que seria uma ética em relação à subjetivação no nosso tempo, para além dos limites da psicologia, já que esta se estabelece no contorno das ciências humanas. Diante da vinculação entre as noções de sujeito, consciência e ciência, a psicanálise pode ser considerada um saber que desafia de algum modo essa mesma série, já que apresenta uma noção de sujeito 
que, além de ultrapassar o campo da consciência, cinde o eu, apresentando-o como ego, id e superego. Além disso, para a psicanálise, claro que a ciência tem fundamental importância a favor da vida, mas não se trata de uma prática desinteressada - ela tem base no interesse humano de se colocar no lugar de Deus, ao desafiar a morte. Isso traz efeitos e alguns deles pretendemos refletir aqui.

Nesse sentido, a psicanálise esbarra no tema da moral pela via em que Nietzsche trabalha a respeito dos interesses humanos, que, para esse pensador, sempre estão atravessados pelas paixões. A psicanálise traz as paixões humanas para seu campo de atuação e, nesse ponto, confronta a ciência moderna, que procura se manter em um terreno neutro nesse aspecto. É claro que essa lógica opera, pois não há como negarmos os avanços e conquistas da ciência que se afirma neutra, dirigida principalmente pela consciência e pelos saberes; no entanto, Foucault, ao propor uma perspectiva histórica genealógica, trazendo para discussão a dimensão das lutas e embates, os jogos de interesse, os jogos de verdade, nos faz perceber o quanto sofre influência de Nietzsche, já que este não separa o campo da moral e da consciência dos interesses próprios às paixões humanas. Desse modo, podemos entender que, se o campo da moral não cobre uma problematização do sujeito relacionado à ética no nosso mundo, ele acaba precisando ser levado em conta de alguma forma, até porque ética e moral muitas vezes se confundem.

O Foucault que se volta para a ética, ao extrapolar as barreiras da moral, oferece ferramentas que servem para a abertura de um campo que possa, ao mesmo tempo em que dialoga com as circunscrições próprias aos sujeitos da nossa sociedade, instaurar um sujeito a partir de um movimento em direção a si próprio, com o propósito de buscar a sua salvação, dado que os modos de existência imiscuidas às práticas capitalistas objetivam os sujeitos, por exemplo, a partir dos saberes sobre a manutenção da vida, o medo da morte, as maneiras pelas quais devem se conduzir como sujeitos morais etc. Assim, as angústias próprias à vida humana ficam assoladas no conjunto de promessas vindas de discursos que vendem ao sujeito alternativas que não alcançam a dimensão ética da vida, que seria uma dimensão do sujeito com ele mesmo em que ele se propusesse a perguntar sobre sua verdade. Estamos tratando a noção de verdade aqui no sentido de um campo de subjetivação onde o sujeito ocupado consigo mesmo trata de se instaurar como um ser vivente a partir de uma ética. Lançando um olhar atento às manipulações engendradas pelo poder, procura voltar para si mesmo em uma direção de salvação 
de si. A vida nos leva a uma série de frustações, a saída pelo poder é a direção oposta à da ética. A salvação de si por uma via ética não recusa nossas limitações; ao contrário, abre um espaço de existência a partir dessas condições, e essa trajetória se dá de modo singular, e conta com uma série de dificuldades. Aceitar-se um ser individual e limitado, tão pequeno diante da grandeza do universo, é uma tarefa difícil, mas necessária para a vida em coletivo. O poder e a revolta estão intimamente relacionados à recusa da nossa condição de seres pequenos e mortais. ${ }^{7}$ O crescimento e o amadurecimento na vida nos dão a dimensão de nossa pequenez, mas, em vez de revoltar-se, o sujeito pode encontrar prazer ao fazer parte desse mundo, retratando tanto o que lhe agrada quanto o que lhe desagrada.

A fronteira entre o campo da psicologia e da filosofia não se apresenta delineada aqui por acaso, tampouco a fronteira entre moral e ética, pois, ao traçarmos uma reflexão ética sobre o tema do sujeito, não podemos deixar de levar em conta que, se o sujeito da nossa época acaba sendo objetivado pelas ciências humanas, ou pela biologia, ou pelo exame, como bem mostra Foucault, isso não necessariamente significa que entre esses jogos de forças objetivadoras não vão surgir forças de resistência. Até porque as forças se dão em uma espécie de caos. E é aí que encontramos saída - força não obedece. Uma certa ordenação se dá, é verdade. Mas força é força, ou seja, elas podem até estar ordenadas para tal ou qual fim, mas podem, sim, ser reestruturadas de outra forma.

É por essa via que encontramos uma pista na obra de Foucault. Ele mostra que Lacan resgata a questão do sujeito implicado com sua verdade na nossa época a partir do preço que se paga para falar a verdade, se propondo a dar forma a suas resistências, operando uma transformação a partir da saída de uma determinada posição subjetiva, dando forma a outra. E Foucault, ao tratar o tema da parrhesía, vai colocar como uma das pontes para pensar o sujeito da nossa época aquilo que Lacan afirma categoricamente como importante - o de se pagar um preço para falar a verdade no nosso mundo.

Assim, para que possamos pensar a noção de sujeito além dos limites do campo científico, escapando dos confins das malhas do poder, ou seja, do campo

\footnotetext{
7 "Quem começa a ter ideia da grandeza e complexidade do mundo facilmente perde de vista seu pequenino Eu. Imerso em admiração, tomado de humildade, facilmente esquece que é ele mesmo um fragmento de forças atuantes e que pode tentar, na medida de sua força pessoal, modificar uma mínima porção do inevitável curso do mundo, desse mundo em que, afinal, o pequenino não é menos maravilhoso do que o grande" (FREUD, 2013, p. 134).
} 
da ciência, é imprenscindível voltarmos o olhar para determinados aspectos da cultura que demarcaram alguns elementos, que, por mais que apareçam de forma naturalizada, foram forjados em determinado ambiente cultural, a partir de um certo jogo de forças.

Por essa via deparamos com uma entrevista de 1965 a Alain Badiou, intitulada Filosofia e psicologia, em que Foucault diz que prefere problematizar a psicologia como forma cultural, e não como ciência, em razão desta estar inscrita em toda uma ordem de eventos próprios à cultura ocidental que deram origem "[à] confíssão, [à] casuística, [aos] diálogos, [aos] discursos e [aos] arrazoados que se podiam pronunciar em certos ambientes na Idade Média, nas cortes de amor, ou, ainda, nos salões do preciosismo do século XVII" (FOUCAULT, 2002a, p. 220). ${ }^{8}$ $\mathrm{Na}$ mesma entrevista, ao ser questionado se a filosofia poderia ser concebida como forma cultural, e se haveria relações interiores ou exteriores entre a psicologia e a filosofia enquanto formas culturais, Foucault avalia que há 150 anos os psicólogos e os filósofos vivem um conflito no que concerne às questões voltadas à reforma do ensino e entende que, desde o século XIX, as ciências humanas vêm se enredando à filosofia pela psicologia. Segundo Foucault:

Pode-se dizer que a filosofia, no mundo ocidental, havia, às cegas, e de algum modo em falso, na obscuridade, na noite de sua própria consciência e de seus métodos, circunscrito um domínio, aquele que ela chamava de alma ou de pensamento e que, agora, serve de herança a ser explorada pelas ciências humanas de um modo claro, lúcido e positivo. De modo que as ciências humanas ocupariam, com todo direito, esse domínio um pouco vago que fora assinalado, mas abandonado como um terreno inculto pela filosofia (FOUCAULT, 2002a, p. 221).

Enquanto esse domínio foi sendo engendrado pela psicologia à luz da ciência, a filosofia passava a se ocupar de outros objetos. Foucault mostra que essa espécie de "divisão de bens" entre psicologia e filosofia se deu em meio ao avanço do positivismo, que resvalou inclusive no domínio da filosofia. Esse novo arranjo produziu efeitos no campo da subjetividade, mais especificamente em relação àquilo que vai ser considerado como verdade no Ocidente. As técnicas

\footnotetext{
${ }^{8}$ Podemos associar essa linha de pensamento de Foucault ao estudo específico do tema da subjetivação desde a Antiguidade e que dá nome ao curso que abre esse momento: "a hermenêutica do sujeito".
} 
interpretativas saem de cena e outras técnicas são organizadas para "extrair a verdade dos indivíduos na Modernidade", como, por exemplo, o exame:

O exame combina as técnicas da hierarquia, que vigia, e as da sanção, que normaliza. É um controle normalizante, uma vigilância que permite qualificar, classificar e punir. Estabelece sobre os indivíduos uma visibilidade através da qual eles são diferenciados e sancionados. É por isso que, em todos os dispositivos de disciplina, o exame é altamente ritualizado. Nele vêm-se reunir a cerimônia do poder e a forma da experiência, a demonstração da força e o estabelecimento da verdade. No coração dos processos de disciplina, ele manifesta a sujeição dos que são percebidos como objetos e a objetivação dos que se sujeitam. A superposição das relações de poder e das de saber assume no exame todo o seu brilho visível. Mais uma inovação da era clássica que os historiadores deixaram na sombra (FOUCAULT, 2002b, pp. 164-5).

O exame como forma de saber ilustra, como bem mostra Foucault, a superposição das relações de poder e de saber. Para Foucault, no que os historiadores da era clássica não atentaram para o exame como objeto de estudo, acabaram deixando de lado elementos de significativa importância para traçar linhas de pensamento sobre o problema do sujeito que vai se desenhando a partir da Modernidade. Mas o pensamento de Foucault, que joga com a ideia de visibilidade o tempo todo, não deixa o exame como técnica, e sua repercussão para a relação do sujeito com a verdade, passar desapercebido. É fundamental que atentemos para isso, pois se trata de uma manobra original no campo da filosofia, que, geralmente, trata a questão do sujeito a partir de grandes temas ligados à ideia do sujeito, como o conhecimento, a moral e a alma, perdendo de vista as forças engendradas na relação entre poder-saber que formam subjetividades. $\mathrm{O}$ exemplo do exame mostra que, com o advento da Modernidade, ao passo que o sujeito vai se tornando objeto do saber dos especialistas, acaba por perder cada vez mais espaço no campo do conhecimento, mesmo sendo concebido como "sujeito do conhecimento". Mas esse campo, como qualquer outro na perspectiva foucaultiana, tem suas fissuras, como pretendemos mostrar com a noção de interpretação na Modernidade. Vale ressaltar, por ora, que o campo do conhecimento no qual se delineia o sujeito moderno possui uma densidade que, para Foucault, é atravessado pelo conhecimento como saber-poder. Assim, pode-se abarcar o conhecimento não como algo abstrato, mas sim na sua tangibilidade, no que diz respeito à forma que se pode dar a determinado conhecimento por meio, por exemplo, da sede de poder, 
onde este poderá ser circunscrito. Ou seja, Foucault, em vez de se manter voltado para uma crítica da subjetividade substancial fundante do conhecimento, vai se voltar para o peso que o pensamento ocidental confere ao sujeito pensante no lugar do sujeito voltado para uma série de preocupações, tal como era desenhado na filosofia antiga, em que o indivíduo, para se instaurar como sujeito temperante, buscava se conduzir referindo-se à verdade como condição ao mesmo tempo estrutural, instrumental e ontológica, ou seja, o acesso à verdade e o aprimoramento ético/ontológico estavam ligados no cerne da instauração do indivíduo como sujeito. Diante do advento da Modernidade, que, para Foucault, afigurou um sistema de dominação engenhoso, já que logrou poder sobre a vida e a morte saberes que dominam não só os corpos como também os pensamentos dos indivíduos (biopolítica e biopoder) -, ele propõe uma problematização da subjetividade na nossa época, destacando a dimensão dos confrontos e de uma certa atividade do sujeito. O enfrentamento do horror à morte, a morte no sentido simbólico, tal como a Modernidade instaurou, parece ser um primeiro passo para nos lançarmos ativamente como sujeitos, retomando a ética do cuidado de si, ao mesmo tempo em que se possa ver o outro sem que seja como aquele que nos ameaça. Tomar a palavra, dar nomes, quebrar o silêncio, eis a nossa tarefa filosófica, tarefa esssa que hoje ficou na mão dos especialistas ligados à área de assistência. A divisão entre os saberes que atribui aos especialistas a ocupação com os mais diversos problemas próprios ao âmbito social acaba gerando uma atitude de esmorecimento por parte dos membros do conjunto social considerados leigos, que acabam, por sua vez, aderindo a discursos vazios, no sentido de que os discursos que aparecem a partir do domínio dos especialistas não são engendrados na direção de transformar as coisas, já que são produzidos pelo poder.

Deparamos com uma entrevista intitulada "Os intelectuais e o poder", concedida a Gilles Deleuze, em que Foucault coloca a questão do silêncio e da importância de se produzirem discursos em cima daquilo que atravessa nossas vidas cotidianamente; por exemplo, os modos pelos quais as instituições intervêm na sociedade. Os gestos e os saberes tidos como naturais, se confrontados, acabam afigurando-se uma considerável resistência ao poder. Nas palavras de Foucault:

Cada luta se desenvolve em torno de uma sede particular de poder (uma dessas inumeráveis pequenas sedes que um pequeno chefe, um guarda da 
HLM, um diretor de prisão, um juiz, um responsável sindical, um redator de jornal pode ter). E designarem-se as sedes, denunciá-las, falar delas em público é uma luta, não porque ninguém tenha consciência disso, mas porque tomar a palavra sobre esse assunto, forçar a rede de informação institucional, nomear, dizer quem fez o quê, designar o alvo é uma primeira revirada do poder, é um primeiro passo para outras lutas contra o poder (FOUCAULT, 2006c, p. 44).

Nessa entrevista a Deleuze, Foucault está apontando para a direção que Deleuze dá, tanto em Nietzsche quanto em Capitalisme et schizophrénie, ao célebre tema do sentido, significado e significante, quando este autor amplia os temas, traçando questões relacionadas ao campo do poder, das desigualdades e de sua luta. Foucault se alinha a esse pensamento, afirmando que, se os discursos de luta, como, por exemplo, os discursos produzidos pelos detentos ou médicos da prisão, podem ser configurados como discursos de luta, é porque eles se apossam, mesmo que pontualmente, do poder de emitir discursos sobre a prisão - discursos legitimados apenas se emitidos pelos administradores e afins. Com isso, Foucault vai diferenciar o discurso de luta do discurso inconsciente, sem os opor, afirmando que a forma de discurso que se opõe ao discurso de luta seria o segredo, o que, para ele, aponta para uma valorização da luta como objeto. Em suas palavras:

O discurso de luta não se opõe ao inconsciente: ele se opõe ao segredo. Isso parece ser muito menos. E se fosse muito mais? Há toda uma série de equívocos a propósito do "escondido", do "recalcado", do "não dito" que permitem "psicanalisar" a baixo preço o que deve ser o objeto de uma luta. O segredo é talvez mais difícil de desvelar do que o inconsciente. Os dois temas que ainda ontem eram encontrados frequentemente, "a escrita e o recalcado" e "a escrita é legitimamente subversiva", me parecem trair um certo número de operações que é preciso denunciar severamente (FOUCAULT, 2006c, pp. 44-5).

Se saber é poder, os discursos emitidos pelos especialistas legitimados nesses lugares circunscritos como matrizes de conhecimento são os saberes articulados pelo poder. Assim, não temos como conceber um campo de conhecimento que esteja preservado do jogo de interesses presentes na própria manutenção da comunidade científica. Os especialistas os difundem a partir de uma economia ligada às formas de sociabilidade próprias a cada momento histórico. Hoje, com as formas de sociabilidade capitalistas, não é simples contar com uma ética que norteie o campo do conhecimento no sentido de escapar a essas formas. Por exemplo, se 
pensarmos na saúde e nos laboratórios farmacêuticos, podemos entender que a doença virou um negócio. Que, por gerar lucros, a saúde se tornou um campo esvaziado de preocupação ética pela vida, restrito aos limites da ética desenhada pelo biopoder, associado, por sua vez, ao sistema capitalista. Isso vai repercutir diretamente na formação dos profissionais de saúde e nos faz lembrar o que Foucault apresenta sobre a ideia de que, no lugar do médico, o que temos são os discursos da medicina, por exemplo. Assim, essa noção de segredo remete a uma certa passividade por parte dos leigos, como se as coisas caminhassem por si sós, como se não fosse possível operar transformações. O capitalismo atinge o coração do pacto civilizatório, interferindo nas bases de uma ética coletiva, pois aponta para uma direção de liberdade relacionada à consquista de bens materiais que vão se concentrar nas mãos de uma minoria, que vai consumir de modo frenético, enquanto a maior parte da população assiste a essa cena do deleite do capital na linha de fogo. A base disso tudo se sustenta na ideia ilusória de que todos podem ter acesso aos bens materiais de consumo, se trabalharem para isso. No nosso mundo ainda encontramos as antigas trincheiras instaladas nas guerras concretas presentes nas periferias, que comercializam bens que não podem circular livremente nos centros urbanos. A noção de segredo se relaciona com uma omissão sobre os modos de sociabilidade que produzem, por exemplo, o racismo institucional e o genocídio da população negra das periferias e favelas. Segredo é não querer saber, é não se implicar politicamente, não refletir sobre esse tipo de coisa; é deixar nas mãos do Estado e ponto.

Essa repartição de interesses ligados a questões práticas, aos territórios, às classes sociais, por exemplo, em sua relação com os saberes constituídos em torno desse mesmo jogo de interesses, acaba exercendo influência sobre os discursos. Sendo assim, essa dimensão das disputas, dos interesses controversos, faz parte dos modos pelos quais se atribui sentido às coisas, as intepretações etc. Esse é um dos pontos que nos interessa neste trabalho. A psicanálise, como qualquer prática que se dá em torno dos interesses da elite, acaba negligenciando levar em conta a dimensão das lutas presentes no campo do conhecimento, nas práticas que dão sentido às coisas, aos eventos etc. Por isso voltamos nossa atenção para esse aspecto de crítica à noção do sentido, da hermenêutica, apontando sempre para a impossibilidade de uma neutralidade, de um conhecimento abstrato. 
O interesse de Foucault e, portanto, o nosso em pensar, criticar e ampliar o tema do sentido, do significado e do significante em torno da ideia de conhecimento e de inconsciente, que leva a outra ideia que vamos trabalhar agora, a de interpretação, aparece de modo claro aqui. O levantamento desses temas nos interessa principalmente por entendermos ser necessário manter sempre aberto à crítica o uso que fazemos das noções com as quais nos propomos trabalhar. Permanecer atentos em manter o pensamento aberto, relançando-o na busca de evitar cair na armadilha de transformar os conceitos frutíferos delineados por Freud em conceitos fechados em si mesmos, que podem acabar se tornando inoperantes se voltados mais para manter vivo determinado campo teórico do que manter viva a tarefa de operar o conceito em uma direção de relançamento incessante, eis uma tarefa indispensável. Claro que os conceitos têm sua história e, quando falamos de relançá-los, não queremos dizer que pretendemos abrir mão de sua trajetória, das forças que os fizeram entrar e permanecer no jogo. Mas, se levarmos em consideração a perspectiva dinâmica das lutas, poderemos nos tornar menos ingênuos ao lidar com os conceitos nos tornando mais ativos para diagnosticar os objetos de nossa resistência.

O saber, na Modernidade, passa a ser detido pelos especialistas, e esse modo de disposição de saber-poder acaba produzindo uma atitude passiva por parte dos sujeitos, donde Foucault vai designar a ideia de "segredo" em contraposição à de "discurso de luta", marcando que o discurso de luta, além de não se opor ao inconsciente, e sim ao segredo, deve ser formulado como objeto.

Começamos a desenhar, a partir do levantamento dessas noções, uma linha fecunda no que diz respeito a alguns pontos relativos ao tema do sujeito - uma linha que passa pelo campo da filosofia e da psicanálise: poder-saber-inconscientesegredo-interpretação.

\subsection{A interpretação na Modernidade: abertura para a produção de sentido}

Se a história do pensamento seguiu um processo evolutivo no qual as técnicas interpretativas pareciam ter ficado para trás, como procedimentos "incultos", principalmente sob o efeito das críticas baconiana e cartesiana, que repercutiram em sua suspensão, a partir de Freud, Nietzsche e Marx o papel da interpretação vai ser relançado, o que demonstra não ter sido totalmente aniquilado pela história. 
Assim, no século XIX, a interpretação entra novamente em cena, embora com um novo rosto. Segundo Foucault:

Se essas técnicas de interpretação do século XVI foram deixadas em suspenso pela evolução do pensamento ocidental nos séculos XVII e XVIII, se a crítica baconiana e a crítica cartesiana da semelhança desempenharam certamente um grande papel para colocá-las entre parênteses, o século XIX e, muito singularmente, Marx, Nietzsche e Freud nos põem diante de uma nova possibilidade de interpretações; eles fundaram novamente a possibilidade de uma hermenêutica. [...] Não me parece que, de qualquer forma, Marx, Nietzsche e Freud tenham multiplicado os signos do mundo ocidental. Eles não deram um sentido novo a coisas que não tinham sentido. Na realidade, eles mudaram a natureza do signo e modificaram a maneira pela qual o signo em geral podia ser interpretado (FOUCAULT, 2008, pp. 42-3).

Quando Foucault fala em mudança da natureza dos signos e de interpretação, está complexificando a ideia de interpretação anteriormente assimilada pelo seu ser simples de significante como era até o Renascimento. Foucault critica a noção de hermenêutica como possuindo um significado profundo pelo fato de essa noção de profundidade se ancorar na prática da confissão sexual usada pelas práticas de dominação social. Para ele, o desenvolvimento de práticas psicoterápicas, como também o de alguns procedimentos médicos em torno da noção de psique, que se dizem capazes de mostrar o significado profundo das coisas a partir de um processo interpretativo infindável, acaba por produzir uma multiplicação dos discursos dos sujeitos falantes. Para Dreyfus e Rabinow, se a cultura aponta para a existência de significados profundos, isso não quer dizer que tal profundidade realmente exista, ou seja, esse modo de olhar pode ser simplesmente uma construção cultural. Desse modo, Foucault mostra que as práticas totalizadoras, além de produzirem a objetivação do homem como sujeito e objeto na nossa sociedade, também investe em sua manutenção como tal.

Em Nietzsche, Freud e Marx, texto que problematiza a presença da hermenêutica na Modernidade, Foucault afirma que cada signo é, nele mesmo, não a coisa que se oferece à interpretação, mas interpretação de outros signos:

A ideia de que a interpretação precede o signo implica que o signo não seja um ser simples e generoso, como era o caso ainda no século XVI, em que a pletora dos signos, o fato de as coisas se assemelharem, provavam simplesmente a benevolência de Deus, e apenas afastavam por um véu transparente o signo do significado. Ao contrário, desde o século XIX, a partir 
de Freud, Marx e Nietzsche, parece-me que o signo vai se tornar malévolo; quero dizer que há no signo uma maneira ambígua e um pouco equivocada de malquerer e de "malevolência". E isso na medida em que o signo já é uma interpretação que não se dá como tal. Os signos são interpretações que tentam se justificar, e não o inverso (FOUCAULT, 2008, p. 48).

O material que diz respeito à hermenêutica moderna não trata a interpretação por uma ótica da interioridade, mas sim a situa em um plano de exterioridade em que as coisas vão se diferenciar, ganhando relevos a partir de uma profundidadedensidade. O signo passa a ser apreendido em sua densidade própria, ao ser concebido por essa função de recobrimento da interpretação. Para Foucault, a interpretação em signos, própria a esse modelo de hermenêutica, não se baseia na revelação de signos primeiros e enigmáticos, e sim na concepção de que em tudo o que se fala existe uma trama de interpretações violentas. Nietzsche, quando afirma que foram as classes superiores que conceberam as palavras, não está pontuando que nelas haja um significado, está afirmando, na verdade, que há a imposição de uma interpretação. Segundo Foucault:

Não é porque há signos primeiros e enigmáticos que estamos agora dedicados à tarefa de interpretar, mas, sim, porque há interpretações, porque não cessa de haver, debaixo de tudo o que se fala, a grande trama das interpretações violentas. É por essa razão que há signos, signos que nos prescrevem a interpretação de sua interpretação, que nos prescrevem revirá-los como signos. Nesse sentido, pode-se dizer que a allegoria e hyponoïa são, no fundo e antes dela, linguagem, não aquilo que deslizou a posteriori sob as palavras para deslocá-las e fazê-las vibrar, mas aquilo que fez nascer as palavras, que as faz cintilar em um clarão que nunca se fixa. Eis por que também o intérprete, para Nietzsche, é o "verídico"; ele é o "verdadeiro", não porque se apodera de uma verdade adormecida para proferi-la, mas porque ele pronuncia a interpretação que toda verdade tem por função velar (FOUCAULT, 2008, p. 48).

Para Foucault, o primado da interpretação, no que concerne aos signos, parece ser o que há de mais contundente na hermenêutica moderna, sobretudo ao nos dar o ensejo de reformular o signo em sua densidade - "nesse espaço aberto, sem fim, vazio, sem conteúdo real, nem reconciliação" (FOUCAULT, 2008, p. 49). Assim, sujeito e interpretação são engendrados ao mesmo tempo em um espaço onde não se encontram delimitadas fronteiras nítidas, marcando, de um lado, uma consciência apta a interpretar e, de outro, um espaço que contém determinados signos. Não é de saberes abstratos que se trata. A partir de Nietzsche, Freud e Marx, 
o signo não é mais concebido separado do intérprete, o que nos leva a não descartar os interesses particulares e sociais e os propósitos morais envolvidos no campo da interpretação, ou seja, a esfera das batalhas, das lutas, das disputas de poder, dos embates concretos e interesses controversos que passam a ser considerados quando nos propomos tratar o campo da subjetivação e seguir o pensamento sobre a subjetivação, que Foucault vai circunscrever sobre as ruínas do campo da intersubjetividade. No presente trabalho, não vamos nos ater a sua visada crítica sobre a intersubjetividade, nossa proposta se resume a lançar alguma luz sobre determinados pontos em torno dos elementos sobre a crítica do sujeito, que nos interessa, por sua vez, para que possamos explorar a noção de sujeito, tarefa indispensável na prática psicanalítica.

Por essa via, interessa-nos lançar mão da ideia de espaço de interpretação como um espaço aberto, se pudermos usá-lo para o fim de uma atividade do sujeito, de uma formulação de si próprio.

\subsection{O homem como homo natura - uma invenção}

O fato de a filosofia ter delineado um campo acerca do pensamento e da alma, posteriormente deslocado para o domínio da ciência, nos incita a problematizar a questão das fronteiras desenhadas pela filosofia desde a Modernidade no que se refere ao tema do sujeito, pois, se nos mantivermos presos a essas fronteiras, mostra Foucault, o nosso pensamento vai acabar se deparando com barreiras intransponíveis. Por isso Foucault aproxima o modo de fazer filosofia hoje da "antropologia", como um aceno para o fato de que os problemas colocados pela filosofia na nossa época não conseguem extrapolar as balizas do que se convencionou chamar de domínio da finitude humana. Segundo Foucault:

Se não podemos mais filosofar a não ser sobre o homem como homo natura ou, ainda, como um ser finito, nessa medida, será que toda filosofia não será, no fundo, uma antropologia? Nesse momento, a filosofia torna-se a forma cultural no interior da qual todas as ciências do homem em geral são possíveis (FOUCAULT, 2002a, p. 221).

O trato do tema do sujeito a partir de uma perspectiva histórica que pretenda ultrapassar os limites da concepção de sujeito como sujeito da consciência, a partir da invenção de uma ideia de homem como homo natura, se impõe como uma tarefa 
ética que não pode ser negligenciada depois do que Nietzsche, Freud e Marx sinalizaram. O "jogo de forças" do qual fala Foucault, circunscreve a cada estrato da história determinados saberes que passam a ser assimilados como verdades. $\mathrm{O}$ signo, que até o Renascimento era tido por uma perspectiva simplista, como portador apenas do aspecto de significante, doravante será entendido em sua complexidade, ou seja, incluindo também os conceitos negativos.

Nesse mesmo colóquio sobre Nietzsche, Freud e Marx, proferido em Royaumont em julho de 1964, registrado também em julho de 1967 no Cahiers de Royaumont, Foucault responde a pergunta formulada por um dos ouvintes, Sr. Kelke:

Minha questão será muito breve: ela se relaciona, no fundo, com o que você chamou de "técnicas de interpretação", nas quais você parece ver, eu não diria um substituto, mas, em todo caso, um sucessor, uma sucessão possível à filosofia. Você concorda que essas técnicas de interpretação do mundo são, antes de tudo, técnicas de "terapêutica", técnicas de "cura", no sentido mais amplo do termo: da sociedade, em Marx, do indivíduo, em Freud, da humanidade, em Nietzsche?

Ao que Foucault responde:

Penso de fato que o sentido da interpretação no século XIX certamente se aproxima do que você concebe por terapêutica. No século XVI, a interpretação talvez encontrasse um sentido do lado da revelação, da salvação. Eu lhe citarei simplesmente uma frase de um historiador chamado Garcia: "Em nossos dias - diz ele, em 1860 -, a saúde substituiu a salvação" (FOUCAULT, 2008, p. 55).

Se as estruturas de espiritualidade próprias à epiméleia heautoû delineiam as obras de Nietzsche, Freud e Marx e dado que se encontram presentes no modelo de salvação cristã, entendemos ser possível, a partir de alguns elementos oriundos da ideia de salvação de si mesmo, já que a descontinuidade nos possibilita tal salto histórico, pontilhar algumas associações entre o tema da salvação antiga e da terapêutica que, na atualidade, pode ser delineado no campo da interpretação.

Nessa linha, pretendemos propor a ideia de um sujeito que se formula a si mesmo, ao mesmo tempo em que se volta para sua vida no presente, em vez de investir em uma espécie de ideal de si mesmo pautado por um modelo biológico fortemente influenciado pelo cristianismo que, posteriormente, engendraria o ideal 
ascético. $\mathrm{O}$ investimento no ideal ascético vai permitir uma aproximação entre o campo da moral e da ciência. Por exemplo, no século XVIII, observa-se o entrecruzamento de práticas penitenciais e de saberes engendrados pela prática psiquiátrica, produzindo o corpo da anomalia com foco na sexualidade, corpo que servirá como base para a instauração do biopoder. A pesquisa de Foucault até os anos 1980 pode ser entendida como uma análise crítica ao biopoder, já que apresenta o caráter histórico de categorias tidas como naturais no Ocidente, tais como sujeito, corpo e racionalidade. A partir do trato do tema da subjetividade em torno do campo da sexualidade relacionado ao tema da confissão, Foucault formula um campo de pesquisa, voltando os seus interesses para o domínio discursivo em relação com a formação da subjetividade, de modo que ultrapasse as práticas de confissão cristã. O campo da subjetivação antiga se torna o cerne de suas pesquisas e podemos considerar que a abordagem desse campo, por si só, acaba caracterizando uma crítica ao biopoder, carregando um certo tom irônico, ao mesmo tempo em que instaura uma perspectiva ética.

Veremos, a partir de agora, que o fato de o "conhece-te a ti mesmo" ter sobrepujado o "cuidado de si" gerou uma série de efeitos para a concepção de cuidado a partir da modernidade. Entre esses efeitos, podemos indicar o afastamento do sujeito de uma atitude de cuidado voltada para si próprio, de ocupação e preocupação consigo que, por sua vez, resultou em um afrouxamento da relação consigo, que, como pretendemos desenvolver adiante, repercute na dimensão ética da vida, tanto no aspecto individual quanto coletivo.

\subsection{A eliminação do cuidado de si como objeto da preocupação filosófica}

Foucault lança o problema das razões que teriam levado à desqualificação da epiméleia heautô̂ no âmbito da preocupação filosófica, que gerou como consequência o seu corte como objeto desse campo. Para Foucault, não há como localizar o momento exato dessa ruptura. O que verificamos é que o acesso à verdade se torna um processo autônomo em relação ao processo do conhecimento, e a exigência de transformação do sujeito e do ser do sujeito passa a ser questão exclusiva do sujeito, preocupação dele por ele mesmo. Para a história tradicional, o prevalecimento do "conhece-te a ti mesmo" sobre o "cuidado de si" teria se dado 
com Descartes, momento no qual a filosofia teria circunscrito o conhecimento como objeto de seu domínio, e teria se estendido para Kant, que teria complementado a ideia atestando que os limites do conhecimento estariam contidos na estrutura mesma do sujeito cognoscente, ou seja, nesse mesmo suporte que proporciona o conhecimento.

As razões do interesse de Foucault por esse problema encontram-se justamente no fato de ele suspeitar dessa interpretação, o que o leva a trabalhar em cima de outra linha de pensamento, percorrendo a noção "esquecida" de "cuidado de si”. De acordo com Foucault:

Os vínculos não foram bruscamente rompidos como que por um golpe de espada. Para começar, consideremos a situação, se quisermos, na direção ascendente. O corte não se fez bem assim. Não se fez no dia em que Descartes colocou a regra da evidência ou descobriu o cogito etc. Havia muito tempo já se iniciara o trabalho para desconectar o princípio de um acesso à verdade unicamente nos termos do sujeito cognoscente e, por outro lado, a necessidade espiritual de um trabalho do sujeito sobre si mesmo, transformando-se e esperando na verdade sua iluminação e transfiguração. Havia muito tempo que a dissociação começara a fazer-se e que um certo marco fora cravado entre esses dois elementos. E esse marco, bem entendido, deve ser buscado... do lado da ciência? De modo algum. Deve-se buscá-lo do lado da teologia (FOUCAULT, 2006a, p. 36).

O desenvolvimento da teologia desde Aristóteles, passando por Santo Tomás, com a escolástica, associou estritamente a reflexão racional ao cristianismo, ajustando o modelo de conhecimento ocidental aos moldes de uma fé que, ao mesmo tempo em que instaurava o princípio de um sujeito cognoscente em geral, vislumbrava Deus como modelo. Para Foucault, é nesse processo que podemos encontrar o germe da ruptura entre o pensamento filosófico e as condições de espiritualidade. Nas suas palavras:

A correspondência entre um Deus que tudo conhece e sujeitos capazes de conhecer, sob o amparo da fé, é claro, constitui sem dúvida um dos principais elementos que fazem [fizeram] com que o pensamento - ou as principais formas de reflexão ocidental - e, em particular, o pensamento filosófico se tenham desprendido, liberado, separado das condições de espiritualidade que os haviam acompanhado até então, e cuja formulação mais geral era o princípio da epiméleia heautô̂ (FOUCAULT, 2006a, pp. 36-7). 
Com isso, Foucault nos mostra que esse conflito pode ser situado no campo de práticas do conhecimento espiritual, no domínio de desenvolvimento de saberes esotéricos, em um conjunto de ideias que seguem uma direção que não desvencilha o saber de um processo de transformação profunda do sujeito. A maior prova de que não havia oposição distintiva entre ciência e espiritualidade se encontra na alquimia. Foucault localiza o problema da passagem à desqualificação do cuidado de si na oposição entre pensamento teológico e exigência de espiritualidade, o que quer dizer que o desenlace, a desconexão, além de não ter se dado de modo súbito, encontra-se demarcado no campo da teologia. Foucault responde a algumas questões formuladas pelo público do curso em questão. Eis um dos problemas formulados: "O que me surpreende um pouco é a impressão que se tem de que antes de Descartes só houve o fugaz aparecimento de Aristóteles, mas que não teve uma espécie de continuidade...”. Ao que Foucault responde:

Houve Aristóteles e houve - creio tê-lo mencionado na primeira aula - o problema da teologia. A teologia é precisamente um tipo de conhecimento de estrutura racional que permite ao sujeito - enquanto sujeito racional - ter acesso à verdade de Deus, sem condição de espiritualidade. Tivemos em seguida todas as ciências empíricas (ciências da observação) etc. Tivemos as matemáticas, enfim, uma quantidade de processos com resultados. Isso quer dizer que a escolástica, de modo geral, já era um esforço para revogar a condição da espiritualidade que havia sido estabelecida em toda a filosofia antiga e em todo o pensamento cristão (Santo Agostinho e assim por diante). Você percebe o que quero dizer (FOUCAULT, 2006a, p. 235).

Outro aspecto que põe em evidência que não é a partir da invenção do cogito cartesiano que tal corte se faz diz respeito à abordagem sobre a relação entre as exigências de espiritualidade e o tema do método para se atingir a verdade. Dentre as mais variadas formas de interrogação, Foucault destaca uma, bem característica do final do século XVI e do início do século XVII - a concepção de "reforma do entendimento", o célebre tratado de Espinosa. Esse exemplo implica o sujeito, e uma série de exigências relativas ao ser mesmo do sujeito, ao problema de sua transformação. O problema do acesso à verdade já era formulado em relação às condições que deveriam ser colocadas para se acessar a verdade, sendo pensado no sentido de buscar definir até que ponto essa verdade traria aquilo que se buscava, que dizia respeito ao bem soberano. Ou seja, nesse tratado deparamos com o modo tipicamente espiritual de abordagem do tema da sabedoria. Segundo Foucault: 
Essa é uma questão propriamente espiritual, e acho que o tema da reforma do entendimento no século XVII é inteiramente característico dos laços, ainda muito estritos, muito estreitos, muito cerrados, entre, digamos, uma filosofia do conhecimento e uma espiritualidade da transformação do ser do sujeito por ele próprio. Se tomarmos agora a questão não na direção ascendente, mas na descendente, se passarmos para o outro lado, a partir de Kant, creio que também aí veremos que as estruturas da espiritualidade não desapareceram, nem da reflexão filosófica, nem mesmo talvez do saber. Haveria..., mas quanto a isso não quero agora sequer fazer um esboço, apenas algumas indicações. Retomemos toda a filosofia do século XIX - enfim, quase toda. Hegel, certamente, Schelling, Shopenhauer, Nietzsche, o Husserl da Krisis, também Heidegger - e veremos precisamente que, seja desqualificado, desvalorizado, considerado criticamente, seja, ao contrário, exaltado como em Hegel, de todo modo, porém, o conhecimento, o ato de conhecimento permanece ligado às exigências de espiritualidade (FOUCAULT, 2006a, p. $38)$.

Pelo ponto de vista de Foucault, não há como não reconhecer nesses pensadores traços marcantes da estrutura de espiritualidade, que pretende acoplar as condições do ato de conhecimento e seus efeitos a uma transformação no ser mesmo do sujeito. Foucault concebe toda a história da filosofia do século XIX como um outro tipo de arranjo, que se propunha refletir as estruturas da espiritualidade no cerne de uma filosofia que, desde Descartes, ou, se situarmos de modo mais abrangente, desde o século XVII, buscava desaferrar-se dessas mesmas estruturas. Foucault entende, no contexto dessa separação do cuidado de si do campo do conhecimento, a significativa situação de aversão entre o círculo dos filósofos tratados como clássicos, por exemplo, Descartes, Leibniz e outros que requerem tal tradição, e o círculo filosófico do século XIX, que apresenta, de modo subjacente, que seja, a antiga questão da espiritualidade, o que acaba por resgatar, sem alarde, "o cuidado de si".

Para Foucault, podemos reconhecer, até mesmo no campo concernente ao saber, uma atenção relacionada ao retorno das estruturas de espiritualidade, no que concerne ao critério estabelecido pelos cientistas, utilizado para reconhecer uma falsa ciência. Esses cientistas se orientam pelo critério de demanda que essas modalidades de saber, não consideradas necessariamente como ciência, garantem proporcionar ao sujeito, que, por sua vez, vai obedecer às exigências de sua conversão ao chegar ao cabo de seu processo. Nessas formas de saber deparamos, 
sem sombra de dúvida, com elementos relativos a algumas exigências da espiritualidade. Segundo Foucault:

Dispensável, por certo, traçar-lhes um desenho: de imediato reconhecemos uma forma de saber como o marxismo ou a psicanálise. Assimilá-los à religião é, evidentemente, total engano. Isso não faz nenhum sentido e nada acrescenta. Em contrapartida, se considerarmos um e outra, sabemos bem que, por razões totalmente diferentes, mas com efeitos relativamente homólogos, no marxismo, como na psicanálise, o problema a respeito do que se passa com o ser do sujeito (do que deve ser o ser do sujeito para que ele tenha acesso à verdade) e a consequente questão acerca do que pode ser transformado no sujeito pelo fato de ter acesso à verdade, essas duas questões, repito, absolutamente características da espiritualidade, serão por nós reencontradas no cerne mesmo desses saberes, ou, em todo caso, de ponta a ponta em ambos (FOUCAULT, 2006a, p. 39).

Ou seja, essa breve análise não pretende reduzir tais formas de saber a formas de espiritualidade, mas nos leva a entender que, se lançarmos um olhar diacrônico atento a uma série de questões, exigências e interrogações em um período de um ou dois milênios, encontraremos o esboço de problemas que pertenceram durante muito tempo ao campo da epiméleia heautoû, consequentemente, da espiritualidade como condição de acesso à verdade.

No entanto, hoje, essas formas de exigência aparecem articuladas sob um prisma social, sendo delineadas como elementos voltados para preocupações tais como "posição de classe, de efeito de partido, o pertencimento a um grupo, a uma escola, a iniciação, a formação do analista etc.” (FOUCAULT, 2006a, p. 40). Ou seja, todo esse conjunto de elementos relacionados ao problema das exigências para a formação do sujeito e o acesso à verdade encontra-se colocado, no entanto, em termos sociais, em termos de organização social. Contudo, se tais questões não são mais pensadas no recorte histórico da existência da espiritualidade e de suas exigências, se foram deslocadas para o âmbito da organização social, isso não se dá sem qualquer tipo de prejuízo. O efeito desse deslocamento do problema - que, na verdade, encontra-se relacionado à velha questão da epiméleia heautoû - para o campo da organização social gerou como consequência o esvaziamento da questão das relações entre sujeito e verdade. Para Foucault:

Parece-me que todo interesse e a força das análises de Lacan estão precisamente nisto: creio que Lacan foi o único depois de Freud a querer 
recentralizar a questão da psicanálise precisamente nesta questão das relações entre sujeito e verdade. Isso significa que, em termos inteiramente estranhos à tradição histórica dessa espiritualidade, seja a de Sócrates, seja a de Gregório de Nissa e de todos os intermediários entre eles, em termos do próprio saber analítico, ele tentou colocar a questão que, historicamente, é propriamente espiritual: a questão do preço que o sujeito tem a pagar para dizer o verdadeiro e a questão do efeito que tem sobre o sujeito o fato de que ele disse, de que pode dizer e disse, a verdade sobre si próprio. Fazendo ressurgir essa questão, acho que ele fez efetivamente ressurgir, no interior mesmo da psicanálise, a mais velha tradição, a mais velha interrogação, a mais velha inquietude dessa epiméleia heautô̂, que constituiu a forma mais geral da espiritualidade (FOUCAULT, 2006a, pp. 40-1).

A relação que pretendemos traçar aqui entre alguns elementos da salvação antiga e o que estamos designando como terapêutica, pautados no trecho recortado acima, que se desenha na atualidade em torno do campo da epiméleia heautoû, visa resgatar principalmente essa ideia de incitar o sujeito a se voltar para si mesmo no sentido de se implicar com seu cuidado, com sua salvação, não no sentido cristão de uma salvação da alma a partir da ideia de uma vida após a morte, mas de se pensar a vida a partir de um enfrentamento dos aspectos destrutivos presentes no campo social, já que qualquer sociedade acaba apertando seus membros, explorando-os etc. Daí a proposta de uma resistência, pois, se essa exploração for combatida, acaba potencializando os sujeitos voltados para uma aposta incessante em uma ética pela vida nesse mesmo conjunto social. A salvação de si estaria relacionada à aposta de cada um na verdade, não em uma verdade existente em um lugar inatingível, mas em uma ideia de verdade que se volte para os elementos históricos que garantiram até então as mais diversas hierarquias, poderes, saberes, e os lugares determinados onde se permite que uns falem em detrimento de outros.

Lembramos que Foucault se preocupa, em toda sua obra, em mostrar, por exemplo, que as divisões entre louco e são acabam repercutindo efeitos, discursos, práticas, saberes etc. sobre os sujeitos, para além dos muros do hospício. Ou seja, a divisão, tal como encontrada em Vigiar e punir, entre os "bons e maus meninos" vai produzir efeitos amplos no campo social, que, se não analisados por um olhar atento, acabam sendo absorvidos como se fossem "naturais" e imutáveis. A verdade que propomos pensar e explorar no nosso trabalho não se apresenta como uma instância abstrata que pairaria sobre as nossas cabeças... Ela tem um chão - a história das lutas, guerras, batalhas e poderes. 


\subsection{A relação entre o sujeito e a verdade: o niilismo como a interpretação do sujeito moderno}

Uma vez colocado o problema do esvaziamento da relação entre o sujeito e a verdade, podemos recorrer a alguns pontos referentes à célebre questão nietzschiana do niilismo, para tentarmos circunscrever tal problema nos dias de hoje. Nietzsche mostra que o ideal ascético é um dos elementos principais que distingue o sujeito moderno, em sua busca incessante em dar um sentido pleno para a existência. Tal afirmação pode servir como um recurso essencial para resgatarmos a noção de sujeito em sua relação com a verdade, mesmo que esse elo tenha sido perdido há tempos no Ocidente. Com Nietzsche, entendemos que, por servir à "enorme lacuna" desde sempre aberta na história da humanidade, o ideal ascético, além de oferecer um sentido à vida, ganhou status, se mantendo como modelo a ser atingido até os nossos dias. Podemos dizer que esse modelo seria pouco dispendioso por dar ênfase a um encadeamento dos afetos em um quadro pautado também pela má-consciência, isto é, pelo sentimento de autoculpabilização (NIETZSCHE, 1998, pp. 80-1) e, nesse contexto, os afetos, ao permanecerem orbitando o sentimento de culpa, acabariam intensificando ainda mais o sofrimento. Nietzsche mostra que esse preenchimento do vazio com o sofrimento e com o sentimento de culpa, fruto do cristianismo, teve efeitos na cultura que acarretaram um processo de indigência dos nossos modos de vida.

Esse sentido dado pelo cristianismo operou na nossa cultura uma espécie de "política de avestruz", pois o desvio da "enorme lacuna" proveniente da falta de sentido característica da Modernidade acabara incrementando ainda mais a sensação de vazio existencial. Nietzsche chama a atenção para esse aspecto evocando a ideia de niilismo suicida: ou seja, a partir da confrontação dessa falta de sentido, devemos trabalhar na direção de propor a construção de uma outra coisa no lugar do sofrimento - pautado no sentimento cristão de culpa e salvação eterna - como perspectiva de vida arraigada em nosso modo de nos conduzir moralmente. Assim, em vez de continuarmos engendrando formas de vida pela ótica do ideal ascético, tentando realizar a tarefa impossível de mascarar o nosso vazio existencial, Nietzsche vem com a proposta de uma aceitação do niilismo extático (CONSTANTINIDÈS, 2009, p. 177), para lançar mão dele como arma no combate ao ideal ascético, destruindo-o a fim de alcançar um lugar radicalmente esvaziado de sentido. Para Constantinidès: 
Se realmente se quer provocar a decisão, evitar qualquer meia medida e atos deseperados e inúteis, que apenas prolongam a crise niilista, é preciso aceitar o fato de não se dominar por inteiro a negação e lhe conceder toda a liberdade para que ela possa consumar sua obra purificadora. O niilismo extático só poderá - na melhor das hipóteses! - nos ajudar a superar a decadência se ele assumir a forma de um "grande niilismo contagiante", que varre todas as certezas imediatas, lançando-nos ao desafio de viver sem a menor segurança, sem o menor apoio, mesmo ilusório. Para libertar, enfim, a ação e o horizonte humanos, até então prisioneiros do "refúgio" da moral, faz-se necessário não apenas rejeitar toda expectativa, mas também superar todo desespero, estar pronto para viver nos confins da incerteza radical, sem sofrer com o absurdo da existência sem esperança de redenção. Com o propósito de tornar possível essa "segunda inocência" da criança, Nietzsche conclama com seus votos a destruição integral e sem dissimulações das últimas sombras de Deus (2009, p. 177).

Interessa-nos neste trabalho lançar uma reflexão sobre essa ideia de vazio existencial, já que entendemos que é a partir do desmantelamento de determinados elementos culturais e da tomada de distância em relação a outros que o indivíduo pode abrir um espaço de criação de si. Um lugar que não seja mais capturável pelo ideal ascético, onde se possa inaugurar um olhar desmistificado do horror à carne, fabricado por esse mesmo ideal, onde haja o reconhecimento da nossa condição humana como a condição de um animal inteligente, para que, diante disso, possamos achar o que, para nós, é uma saída possível, pela qual se pode obter prazer dentro dos limites próprios à vida, um verdadeiro sentido para a existência - um sentido estético. Foucault nos dá apoio nesse sentido quando, no curso de 1983, $O$ governo de si e dos outros, afirma que empreendeu diferentes rotas de acesso para viabilizar uma história das experiências da loucura, da criminalidade e da sexualidade, aquilo que ele chamou de focos de experiência relevantes para a nossa cultura. Por essa via ele afirma que forneceu a esse trajeto um enfoque maior aos aspectos negativistas, ou seja, uma espécie de substituição da teoria do conhecimento, do poder ou do sujeito pela análise de práticas históricas determinadas. Foucault realça que lança mão de um negativismo nominalista, quando, por exemplo, substitui universais como loucura, crime e sexualidade pelo enfoque em experiências que organizam formas históricas singulares. Assim, ele valoriza o niilismo para, a partir dele, obter uma forma de reflexão que, segundo Foucault: 
[...] em vez de indexar práticas a sistemas de valores que permitam medi-las, inscreve esses sistemas de valores no jogo de práticas arbitrárias, mesmo que sejam inteligíveis. Diante dessas objeções ou, para dizer a verdade, dessas "recriminações", é necessário ter uma atitude muito firme, porque são "recriminações", isto é, objeções tais que, ao se defender delas, se subscreve fatalmente ao que elas sustentam. Sob essas diferentes objeções/recriminações, supõe-se ou impõe-se uma espécie de contrato implícito da decisão teórica, contrato ao fim do qual historicismo, nominalismo, niilismo são desqualificados de saída: como ninguém ousa se declarar tal e a armadilha consiste em não poder fazer outra coisa senão aceitar um desafio, isto é, subscrevê-lo... (2010a, p. 7).

Assim, Foucault critica essas objeções, ou, como ele também está chamando, essas recriminações, afirmando que isso, na verdade, não teria fundamento, já que não houve nenhum dispêndio sobre os dados. Por exemplo, para Foucault, em relação ao historicismo, não houve qualquer exame mais minucioso em relação aos efeitos da análise histórica no campo do pensamento histórico. No que diz respeito ao nominalismo, importante pensar nos efeitos dessas críticas nominalistas na análise das culturas, dos conhecimentos, das estruturas políticas e das instituições. E sobre o niilismo, por fim, é fundamental que pensemos em seus efeitos para a corroboração e a transformação dos sistemas de valores. Essa linha de pensamento de Foucault vai ao encontro da ideia de niilismo extático trabalhada por Constantitinides e que nos pareceu pertinente apresentar no contexto deste trabalho.

A proposta de uma reflexão do tema da subjetivação na via de um diagnóstico do presente vai ser delineada diante da constatação de que, se o biopoder produz os sujeitos a partir de um processo de objetivação, os meios pelos quais os saberes são forjados em torno desse processo também se dão de acordo com os interesses convenientes ao mesmo modelo de poder. Há, portanto, a necessidade de se criar uma abertura no campo do conhecimento que dê lugar a práticas históricas determinadas. A abertura dessa lacuna é fundamental para a invenção de um lugar mais criativo, quando nos propomos uma reflexão sobre o tema da subjetivação, de maneira a expandir os limites do domínio do que se concebe como a estrutura cognoscente do sujeito do conhecimento. Com Foucault, faz-se urgente tecer uma análise do sujeito que conceba a razão de maneira ampliada pelos sentidos, pelas paixões, pelos desejos, pelo mal-estar, pelo fato de querermos as coisas, ou não querermos, enfim. Ou seja, a ideia de conhecimento se alarga, e a razão entra na cena do conhecimento sem destituir o corpo, tal como faz o ideal ascético, posto 
que o corpo é entendido como a sede das paixões. Afinal, sabemos que a ideia de uma consciência como domínio considerado capaz de exercer controle sobre as paixões se dá na esteira da organização cristã de uma determinada carne, que vai preencher a noção de corpo na Modernidade. ${ }^{9}$

Propondo-nos resistir ao ideal ascético e admitindo uma produção realizada a partir de nossas limitações, vamos nos ater a alguns elementos desse campo do cuidado de si, da epiméleia heautoû, já que apostamos que, se ele não foi totalmente eliminado da história, e se mantém operando, mesmo que sobre outras bases, estamos diante de um conjunto de forças que, por ser força, poderá ser usada para resistir e transformar as coisas.

\subsection{A subjetivação antiga no rastro da hermenêutica}

Ao pensarmos o tema do sujeito a partir de Foucault e de sua análise de um modelo de subjetivação antiga, não podemos abrir mão do legado da análise do poder. Ele propõe situar o sujeito na prática da filosofia ultrapassando os limites da teoria filosófica, o que ele designou como onto-etho-poiética. Parece-nos que essa saída se dá pela força do acontecimento histórico que irrompe em meio às análises de poder: Maio de 68. Em uma conferência no instituto franco-japonês de Kansai, em Quioto, intitulada “A sociedade disciplinar em crise”, Foucault é questionado sobre a sua teoria do poder em relação ao poder clássico, especialmente sobre o que haveria de novo na sua teoria. Aqui, vemos que, para ele, mais que o conteúdo teórico, o que realmente distingue uma pesquisa é a sua perspectiva:

Não é a teoria que é diferente, mas o objeto, o ponto de vista. Em geral, a teoria do poder fala disso em termos de direito, e formula a questão de sua legitimidade, de seu limite e de sua origem. Minha pesquisa incide sobre as técnicas do poder, sobre a tecnologia do poder. Ela consiste em estudar como o poder domina e se faz obedecer. A partir dos séculos XVII e XVIII, essa tecnologia se desenvolveu enormemente; todavia nenhuma pesquisa foi realizada. Na sociedade atual, nasceram diversas resistências, tais como o feminismo, o movimento estudantil, e as relações entre essas resistências e as técnicas do poder constituem um objeto de pesquisa interessante (FOUCAULT, 2006c, p. 267).

\footnotetext{
${ }^{9}$ Discorreremos sobre o tema da carne, que vai preencher a noção de corpo na Modernidade, em subcapítulo posterior, intitulado "O corpo científico tem base em uma fisiologia moral da carne".
} 
Maio de 68 representa a produção de uma resistência, dado que, em plena época da disciplina, vemos figurar subjetividades que ultrapassaram as barreiras dos corpos dóceis, o que mostra que a subjetivação produz efeitos tanto no aspecto individual quanto no social. Em maio de 1968 as manifestações apontavam para uma série de reivindicações que uniam estudantes e operários, singularidades afetadas pelo poder disciplinar, já que a insurreição uniu forças que extrapolavam as demandas habituais relacionadas ao trabalho, como, por exemplo, melhorias salariais. Quando seguimos a pesquisa sobre o tema do sujeito elaborada por Foucault, não podemos deixar de localizar o efeito que essas contestações produziram na sua obra, que foi principalmente, em meio a um movimento revolucionário pontual, mas efetivo, um confronto de ideias relacionadas à cultura - contra as velhas ideias que fundamentavam a sociedade da época, novas ideias em torno de questões delineadas por uma velha moral sobre a educação, a sexualidade e o prazer em pleno processo de captura pela sociedade de consumo.

Ou seja, no mundo moderno, as subjetividades engendradas pelo poder disciplinar e pela biopolítica eram cada vez mais formadas a partir de uma velha moral, que nunca deixou de ser sustentada pelo poder econômico. Assim, hoje deparamos com subjetividades organizadas em uma rede de relações interpessoais, em um jogo de forças provenientes da economia, especificamente do capitalismo neoliberal, donde uma ideia de liberdade pautada no poder aquisitivo, figurando subjetividades mediante a capacidade de consumo dos indivíduos. Se esbarramos aqui, mais uma vez, com o poder, isso não quer dizer que Foucault tenha feito um percurso - priorizando o poder como objeto - que, posteriormente, teria sido esgotado e dado lugar à pesquisa do sujeito. Não se trata disso. O poder e o sujeito encontram-se entrelaçados desde os primórdios de sua pesquisa, e parte dela descreve os efeitos do poder na formação dos indivíduos, como no caso do poder disciplinar, por exemplo, que, sob um crivo moral ligado ao desenvolvimento econômico da nossa sociedade, forma subjetividades. Ou, como observamos a partir da segunda metade do século XVIII, quando o biopoder sobrevém, não eliminando a tecnologia disciplinar, porque se estrutura em outros pontos de apoio e opera com instrumentos distintos, também passa a exercer forte influência na formação de subjetividades.

Com as mudanças observadas a partir dos anos 1960, aparecem outras categorias de pessoas, gerando inevitavelmente uma tensão social, que faz com que 
a parte conservadora reivindique sua antiga influência. Foucault reconhece nesse confronto a necessidade de pensar uma possível sociedade sem disciplina. Sem dúvida, esse diagnóstico da época acaba exercendo influência na transição da fase da análise do tema do sujeito objetivado pelas tecnologias do poder, como a disciplina e o exame, para o período da subjetivação, voltado para a temática das técnicas de si. Trata-se de uma maneira de refletir sobre o sujeito desvencilhado da disciplina. Se novas subjetividades se formaram dentro dos limites estabelecidos pelos campos de formação dos sujeitos disciplinares, vigentes na sociedade ocidental, é sinal de que há saída - o sujeito pode ser inventado. Cito Foucault:

Há quatro, cinco séculos, considerava-se que o desenvolvimento da sociedade ocidental dependia da eficácia do poder em preencher sua função. Por exemplo, importava, na família como a autoridade do pai, ou dos pais, controlava os comportamentos dos filhos. Se esse mecanismo se quebrava, a sociedade desmoronava. O assunto importante era como o indivíduo obedecia. Nestes últimos anos, a sociedade mudou e os indivíduos também; eles são cada vez mais diversos, diferentes e independentes. Há cada vez mais categorias de pessoas que não estão submetidas à disciplina, de tal forma que somos obrigados a pensar o desenvolvimento de uma sociedade sem disciplina. A classe dirigente continua impregnada da antiga técnica, mas é evidente que devemos nos separar, no futuro, da sociedade de disciplina de hoje (FOUCAULT, 2006c, p. 268).

O trabalho da ética de Foucault segue em uma direção relacionada às questões primárias formadoras dos sujeitos, relacionadas à educação, tanto no círculo familiar quanto nos círculos ligados à educação e à formação dos sujeitos de modo mais amplo, já que os afetos são moldados de acordo com as relações sociais - com as instituições, a família e o círculo de amigos. Das técnicas de poder modernas, Foucault se volta para as técnicas de si antigas, delineadas pelos pensadores da salvação de si, que partem do princípio de que, se a natureza não nos fez para pensar, se fomos nós que inventamos o pensamento, é nossa tarefa dar vida à existência, colocar em trabalho esse trabalho que não está acabado. Se a natureza não nos preparou para pensar, por efeito disso temos muito mais defeitos do que virtudes, logo o éthos vai para além de sua naturalidade, implicando-nos, nesse esforço e nessa transformação, pois, entre os animais, somos aquele ao qual se tem que dar acabamento, o que implica um esforço ético sobre nós mesmos - ideia de transfiguração. No nosso mundo, a formação dos sujeitos está ancorada nas redes de saberes-práticas institucionais, seguindo uma ética de controle sobre a vida pela 
via daquilo que é considerado certo ou errado a partir dos critérios estabelecidos pela biopolítica e pelo biopoder. Para Foucault, esse modo de subjetivação moderno precisa ser repensado. A leitura que Foucault faz da subjetivação antiga, formulada nas escolas filosóficas cínicas, epicuristas e estóicas, pode oferecer uma saída, pois desenha um campo de subjetivação onde a ideia de transfiguração ${ }^{10}$ aparece extrapolando as ideias de certo e errado, pautadas nas concepções de bem e mal, tão valorizadas no mundo moderno e que produzem efeitos nos mais diversos domínios, efeitos esses nitidamente problemáticos.

\subsection{0 sujeito da revolução: uma nova linha de subjetivação na Modernidade}

Lembrando que Foucault constrói as ferramentas com as quais busca apreender os objetos de sua pesquisa, no curso A hermenêutica do sujeito, onde apresenta uma massa de material referente a experiências antigas em torno da ideia da epiméleia heautoû, deparamos com o exemplo de um modelo de sujeito que irrompe com a revolução. As análises do poder nos levaram a conhecer a importância de olhar para a subjetivação, pois, em meio ao modelo de indivíduo da nossa época, submetido a técnicas de dominação e técnicas discursivas, vemos se formarem sujeitos a partir de técnicas externas, de acordo com os eventos históricos, tal como o indivíduo constituído por forças revolucionárias. A perspectiva de Foucault traça uma delimitação subjetiva na esfera da revolução, o que nos conduz ao ponto de vista crítico foucaultiano da história, que dá atenção para a ação política transgressora, e não mais revolucionária, pois os anos 1960 podem ser contemplados como a abertura de uma fissura na política graças às forças da manifestação cultural que questionou as categorias clássicas de condução da ação política, instalando a criação e a invenção como ferramentas da prática política.

A filosofia de Foucault parece nos provocar uma espécie de afecção que nos leva a olhar para nossa sociedade, considerando as malhas de saber-poder que a sustenta, problematizando as categorias políticas, sempre as relançando, mantendo uma abertura a novos questionamentos, e nunca o fechamento em uma possível

\footnotetext{
${ }^{10}$ A ideia de transfiguração, nas práticas de si antigas, estavam relacionadas à ideia de corrigir maus hábitos que necessariamente todos possuem e, assim, operar transformações em si mesmo. Verificar subcapítulo "Paraskaué - suporte emocional para a vida".
} 
solução. O momento da revolução cabe aqui como exemplo para mostrar que, mesmo em um plano de revolução que se proponha a mais satisfatória organização social possível, a partir das categorias políticas clássicas, vemos irromper uma produção de discursos autênticos, figurando um modelo de sujeito da enunciação por meio da invenção. Observa-se, a partir do que foi dito anteriormente, que a noção de conversão a si na vida política, a partir do século XIX, se configura como uma "subjetividade revolucionária":

O interessante é que, no fundo - é uma hipótese -, penso que, nem no decurso do que chamamos de revolução inglesa, nem do que chamamos "a Revolução", na França, em [17]89, jamais teria havido alguma coisa que fosse da ordem da conversão. Parece-me que é a partir do século XIX - repito, a se verificar melhor -, seguramente por volta dos anos 1830-1840, e justamente em referência àquele acontecimento fundador, histórico-mítico, que foi [para o] século XIX a Revolução Francesa, que começou a definir esquemas de experiência individual e subjetiva que consistiram na "conversão à revolução". Parece-me ainda que não se pode compreender o que foi, ao longo do século XIX, a prática revolucionária, o que foi o indivíduo revolucionário e o que foi para ele a experiência da revolução, se não se levar em conta a noção, o esquema fundamental da conversão à revolução (FOUCAULT, 2006a, p. 256).

Com isso, Foucault parece mostrar que as forças presentes na esfera social formam as subjetividades e, nesse sentido, esse jogo de forças aponta para uma densidade, quebrando a ideia de interioridade geralmente atrelada ao tema do sujeito. Nessa linha, passamos para uma ideia importante para o nosso trabalho, que é a associação entre biopoder e capitalismo, pois Foucault vai dizer que o biopoder foi fundamental para o desenvolvimento do capitalismo. Por meio do biopoder pautado no plano da biopolítica, endossa-se a inserção dos corpos no aparato produtivo, organizando as populações de acordo com os processos econômicos.

O processo de desenvolvimento do capitalismo industrial, do século XVIII para o século XIX, vai convocar uma massa de desocupados como instrumento da política salarial. Nesse contexto emerge o indivíduo proletário, que, em sua reivindicação por melhores salários e por direitos gerais, se afigurava como elemento essencial para a prática burguesa, visto que o capital dependia de sua existência. Importante lembrar que Foucault não entende o controle da sociedade sobre os indivíduos apenas pelo viés da consciência ou da ideologia, há que se incluir o corpo. A disciplina como uma técnica, dentro de uma microfísica do poder, 
desenha uma biopolítica em que os corpos, quanto mais tecnicamente úteis, mais dóceis são.

Nos anos 1960, no âmbito dessas lutas disciplinares, alguns grupos ultrapassaram os limites das reivindicações por melhores condições dentro do esquema organizado pelo poder disciplinar, num clima generalizado de insatisfação pelo que as políticas de esquerda podiam oferecer - por um lado, os direitos, contudo, em nome de uma submissão eterna. Isso porque o operário se manteria no mesmo lugar, com o seu trabalho constituindo o capital, e o burguês, em um estrato superior, no plano da organização. Essa ordenação econômica declina em 1989 com a queda do muro de Berlim e com o fim da URSS, e o trabalho vai passar para o plano da invenção, gerando subjetividades. Em um sentido figurado, podemos dizer que, doravante, a alma é que vai para o chão da fábrica, fazendo emergir uma série de profissionais de atenção ao indivíduo que busca se organizar de acordo com um modelo que tem em vista, por exemplo, os serviços de assistência e atenção à saúde. O médico se transformou em um serviço de assistência e atenção à saúde. Os planos de saúde agora são de empresa: em se tratando de saúde pública ou privada, se o indivíduo estiver em uma situação de precariedade na esfera profissional, não poderá ter um plano de saúde de acordo com suas reais necessidades. Fica em débito o sujeito, em um movimento de inflexão para si mesmo, com vistas a se pensar, a refletir sobre si, na direção de um descolamento do capitalismo, que é um ditador de desejos-fetiches, para entrar em contato com os afetos e, a partir daí, sim, tentar formular por essa via suas reais necessidades. Refletir sobre o capitalismo me parece tarefa imprescindível no nosso tempo. Isso porque as angústias de cada um acabam estando muito relacionadas às limitações humanas, principalmente o medo da morte como impotência maior diante da vida. No capitalismo, essas limitações e angústias são estritamente relacionadas a uma ideia de mercado - como se fosse possível dar conta de afetos humanos, como o medo, por exemplo, ou o desejo, a partir da compra dos objetos prometidos pelo império capitalista, por exemplo, ou pelos melhores profissionais de saúde e das melhores instalações médicas, no caso das deteriorações inevitáveis do corpo. Esse esquema de conexão entre os afetos dos indivíduos com o mercado e suas promessas está fadado ao fracasso, já que obtém uma produção, sim, só que de fantasmas. Daí essa ideia da alma no chão da fábrica, como se fosse possível produzir objetos que possam atender as reais necessidades dos indivíduos. A Modernidade seria uma época que se apresenta 
como esclarecida, racional, desligada de Deus, no entanto sua ligação com as promessas do capital também pode ser considerada obscura.

Nesse panorama, Foucault traz à tona a experiência do indivíduo revolucionário no momento em que está proferindo as aulas do curso de 1982, ou seja, em pleno curso sobre a subjetivação antiga, fazendo uma aproximação do império atual com o império antigo. Isso tem tudo a ver com a luta dos anos 1960/1970 e com as reivindicações dos grupos não priorizados pelos interesses do Estado, como, por exemplo, as mulheres, as crianças e os homossexuais, por apontarem para uma direção inventiva, uma saída das amarras do aparato social e de suas promessas. A ação política após Maio de 1968 vai se orientar pela ótica da transgressão, visando a uma política da felicidade, da amizade e do intolerável como opção à política clássica do medo e da esperança - que poderiam ter como efeito uma atitude de passividade. Uma revolução orientada a mudanças culturais.

Essa nova visão de uma política da felicidade está pautada principalmente em Espinosa, que mostra que uma posição de esperança está relacionada a expectativas futuras de um mundo melhor por vir, tal como desenhado pela filosofia de Platão. Esse posicionamento pode acabar despotencializando as forças dos indivíduos, no sentido de uma prática efetiva no presente, pois a felicidade, ao contrário da proposta política clássica, gera uma força imediata. Isso não quer dizer que não se pode ter esperanças, o que parece impossível, mas procurar construir uma resistência às forças conservadoras, pois o ato de resistir já é, por si só, um gesto ativo, que traz no movimento em si o gosto pela transformação das coisas.

A política nas mãos do poder institucional traz um círculo de esperança e decepção por parte dos indivíduos, que, se limitados a essas instâncias do poder, acabam se tornando seres amargurados, devido à passividade inerente a essa posição, em que as forças em potencial ficam encerradas no aparato social, que as usa para se retroalimentar. Acreditamos ser nossa tarefa pensar no trabalho crítico sobre aquilo que, para nós, está tão naturalizado, no que diz respeito, por exemplo, às variadas facetas relacionadas aos papéis sociais. Poder abrir espaço de reflexão sobre o que aparece como as novas formas de relação que estão emergindo hoje, espaços que extrapolem as barreiras que desenham os campos de saber estabelecidos, as especialidades conhecidas, eis nossa tarefa filosófica e ética.

Por essa via, lançamos aqui, no lugar da velha e tão natural pergunta "o que podemos fazer?”, a pergunta “como procurar me posicionar diante dessa situação 
que me toca?”. É assim que entendemos a ideia de diagnóstico do presente delineada por Foucault, para que possamos dar um passo adiante, mesmo não tendo nenhuma certeza de onde necessariamente se vai chegar, mas apostando nas forças próprias ao deslocamento.

Se nos propomos tomar alguma posição diante do que nos espanta, diante daquilo que nos traz algum sentimento de indignação, ficamos mais próximos de produzir uma verdade a partir de um exercício do pensamento, não aceitando qualquer tipo de produção de saber que consideramos ter sido esquematizado, tomando como base deduções lógicas tidas como despretensiosas, ou, outro exemplo bem típico da nossa época, uma produção proveniente de uma mídia comprometida com a formação de uma opinião pública. A ideia de salvação de si tal como elaborada pelos antigos se aplica à noção que eles tinham de que o poder manipulava os fatos de acordo com os interesses voltados para sua manutenção. $\mathrm{O}$ ponto de vista foucaultiano entende o poder da nossa época a partir de uma tecnologia de manipulação dos corpos e do pensamento, e por isso inclui as fantasias no campo do conhecimento, como estamos procurando apresentar neste trabalho. Partimos do ponto de vista de que o poder é cego e mudo, como bem afirma Foucault, e que manipula sem o dizer, sendo que tal gesto produz efeitos sobre os indivíduos, no campo mesmo das fantasias, já que é o poder que vai fazer falar e ver:

Le pouvoir n'est pas omnipotente, omnisciente, au contraire! Si les relations de pouvoir ont produit des formes d'enquête, d'analyses des modèles de savoir, c'est précisément parce que le pouvoir n'était pas omniscient, mais qu'il était aveugle, parce qu'il se trouvait dans une impasse. Si on a assisté au développement de tant de rapports de pouvoir, de tant de systèmes de contrôle, de tant de formes de surveillance, c'est précisément parce que le pouvoir était toujours impuissant. Au regard de la nature de mes analyses, il est donc facile de montrer que ce que l'on m'attribue est un pur et simple mensonge (FOUCAULT, 2001, p. 628).

E, se esse gesto não se dá de modo evidente, fica-se sem saber de onde vem. Como ilustração, se nos situamos na nossa época, especificamente na relação do indivíduo com a verdade sobre si próprio, além de ser tratada em um esquema externo a ele mesmo pelos especialistas, por meio das tecnologias modernas, ela acaba vindo de modo obscuro. Isso porque os indivíduos acabam se sentindo manipulados, mesmo acreditando participar de maneira plena do processo de acesso 
ao conhecimento sobre si, por exemplo, na "interlocução" que faz parte do contato com o especialista ao qual se recorre quando se pretende saber sobre si mesmo.

Interessante pensar a ideia foucaultiana de diagnóstico do presente diante desse problema, pois traçar diagnósticos é tarefa a se fazer independentemente da situação que se está vivenciando. Até porque as expectativas dos indivíduos raramente são atendidas, como nos mostra a psicanálise - Lacan especialmente traça uma análise do desejo como algo que busca sempre mais e mais. Sendo assim, o que se deve ter em mente é tomar uma direção ativa de transformação de si e do outro, fazer da própria vida uma experiência estética. Uma experiência estética não pode ser arrebatada pelo mercado. Tal como o artista socialmente engajado, que não vai produzir objetos a partir das demandas de mercado, aquele que vai se proporcionar uma vida virtuosa não vai ser simplesmente conduzido pelas tramas do poder; vai buscar salvar a si mesmo por meio da destruição das ilusões construídas pelo capitalismo, modelo de poder que configura a nossa época, desnudando o mundo em que vivemos, abrindo espaço para uma autêntica contrução de sentidos a partir do que realmente se tem. Foucault mostra em toda a sua obra, não importa de qual período histórico esteja tratando, que a história verdadeira é a história de batalhas, lutas, disputas de poder, embates concretos etc. E, cada vez mais, o império econômico assola a nossa capacidade criativa de viver como animais sociais, consumindo as forças que são essenciais para se conquistar o direito de vivermos em uma comunidade.

Vai ficando cada vez mais clara, diante da inegável fragmentação do sujeito, do problema da velocidade do tempo, dos mais variados arranjos de sujeitos e da emergência dos mais diversos perfis no lugar do que antes conhecíamos como identidade, em curso na nossa época, a importância de lançar uma reflexão sobre a questão do sujeito por outras vias que as habitualmente utilizadas. Por exemplo, não nos parece fazer sentido, hoje, um retorno da revolução - a história mostra os equívocos presentes nela. Interessa-nos principalmente aqui, mostra Foucault, entender que precisamos pisar firme sobre o terreno da história, principalmente em um mundo fluido como o nosso, onde verificamos, ao mesmo tempo, a presença de forças fundamentalistas girando em torno de ideias extremamente conservadoras.

Não é à toa que a pesquisa sobre a subjetivação salta para o domínio de modos de subjetivação antiga, elaborados pelos estoicos, cínicos e epicuristas, que refletiam sobre as forças da vida, os males que podem vir do mundo, tomando como 
meta principal na vida a incessante necessidade de se transformar, construindo virtudes a partir dos acontecimentos, sem filtrá-los ou desprezá-los, e de critérios morais. Se nos deparamos com o fracasso de uma ideia revolucionária, como a história mostra, e propomos o resgate da noção de cuidado de si no nosso mundo, tal como Foucault pensou, isso não quer dizer que optamos por uma atitude egoísta devido a uma experiência fracassada. O cuidado de si, hoje, longe de um posicionamento individualista, se volta para uma prática subjetiva de instauração de sujeitos que assim se colocam ao combaterem um mundo ilusório, uma bolha em torno de si, sustentado pelas esperanças asseguradas pelos ideais. Quebrar as esperanças no nosso mundo não significa adotar um posicionamento pessimista. Ao contrário, em um mundo dominado por forças imperialistas, um sistema baseado em um processo constante de especulação, a esperança se torna sinônimo de mercadoria, que fomenta uma concepção mercadológica pela qual tudo passa a ser visto como objeto de consumo: inclusive os afetos, as representações de nós mesmos etc. ${ }^{11}$

\subsection{A tarefa de pensar uma ética de si diante da fragmentação do sujeito}

Até os anos 1980 Foucault problematiza a questão do sujeito encerrada no aparato social, fundindo subjetivação e sujeição, já que, até essa etapa de sua obra, o sujeito não poderia se liberar das amarras do poder - inatingível e indialogável. Nesse ponto, abre-se um espaço para pensarmos que, se o poder, como mostra Foucault, é cego e mudo, acaba se tornando facilmente associado ao conjunto de

\footnotetext{
${ }^{11}$ Como um exemplo atual de um trabalho concreto em torno dessa proposta da subjetivação, apresento um fragmento retirado do texto para o projeto Mujawara, escrito por Alessandro Petti, Grupo Contrafilé, Sandi Hilal e outros: "Desde março de 2014, a dupla de arquitetos Sandi Halil e Alessandro Petti possibilita à comunidade de refugiados palestinos produzir novas formas de representação dos campos - e de si mesmos - e com isso superar imagens estáticas e tradicionais de vitimização, passividade e pobreza, ao sugerirem novas configurações espaciais e políticas. $\mathrm{O}$ Contrafilé tem trabalhado a questão da terra com a construção de "quintais", por meio do projeto $A$ rebelião das crianças. Colocando o corpo para trabalhar a terra, na terra, através da terra, o grupo cria um espaço coletivo para elaborar e brincar que é sobretudo acesso a um espaço de liberdade. A Casa de Cultura Tainã é um espaço político de produção cultural e educativa. Criada por T. C. Silva, é o ponto inicial da Rede Mocambos, que conecta comunidades quilombolas por meio da internet e do plantio ritual de baobás. Suas conexões horizontais e não lineares subvertem a noção enraizada de uma época passada que não agiria mais sobre o presente, fazendo com que esses tempos outros irrompam e despertem reflexão crítica. Fundado na cidade de Arataca em 1995 por trabalhadores ligados ao Movimento dos Trabalhadores Rurais Sem Terra, o Terra Vista define-se simultaneamente como assentamento e quilombo. Líder regional na produção de alimentos orgânicos, desenvolveu um programa educacional completo, desde o Ensino Fundamental até a formação profissionalizante em agroecologia (Catálogo da 31 $1^{\mathrm{a}}$ Bienal de Artes de São Paulo, 2014).
} 
forças fantasmagóricas produzido na sociedade moderna dominada pelo capitalismo. ${ }^{12}$ Isso porque, se a sociedade moderna se caracteriza por uma "ditadura da ilusão" (DEBORD, 1997, p. 16), que se instaura no espaço que se abre quando os indivíduos se desviam das preocupações mais essenciais do decorrer da vida e passam a ter suas forças voltadas para o poder, o processo de enfeitiçamento da mercadoria, no capitalismo, opera um campo de formação de fantasmas, já que os valores envolvidos nas criações sociais acabam sendo superinvestidos no circuito próprio do capital, esvaziando a dimensão das relações humanas. Por exemplo, o individualismo, que, na nossa época, é tido como algo valorizado, equivalendo à ideia de força, descaracteriza a rede de apoio inconteste no corpo social na qual todos nós nos encontramos assentados.

Os sujeitos-consumidores acabam capturados por uma obsessão direcionada à aquisição de mercadorias-fetiche, dando à vida um sentido produzido por referenciais externos, como a publicidade e a moda, deixando para trás outras maneiras de investir a vida, como, por exemplo, por meio de um sentido cultural, intelectual ou político.

Pela via das resistências, contudo, a partir de uma composição de forças presentes no aparato social, Foucault passa a entender que, no campo formado a partir dessas forças de resistência, se pode delinear algum campo de criação de outras formas de subjetividade. Esse caminho não pretenderia se apresentar como uma saída radical, até porque toda sociedade amarra os indivíduos de alguma forma, então uma liberdade total só poderia ser pensada em um nível utópico. Pode-se

12 "O caráter misterioso da forma-mercadoria consiste, portanto, simplesmente no fato de que ela reflete aos homens os caracteres sociais de seu próprio trabalho como caracteres objetivos dos próprios produtos de trabalho, como propriedades sociais que são naturais a essas coisas, e, por isso, reflete também a relação social dos produtores com o trabalho total como uma relação social entre os objetos, existente à margem dos produtores. É por meio desse quiproquó que os produtos do trabalho se tornam mercadorias, coisas sensíveis-suprassensíveis ou sociais. A impressão luminosa de uma coisa sobre o nervo óptico não se apresenta, pois, como um estímulo subjetivo do próprio nervo óptico, mas como forma objetiva de uma coisa que está fora do olho. No ato de ver, porém, a luz de uma coisa, de um objeto externo, é efetivamente lançada sobre outra coisa, o olho. Trata-se de uma relação física entre coisas físicas. Já a forma mercadoria e a relação de valor dos produtos do trabalho em que ela se representa não têm, ao contrário, absolutamente nada a ver com sua natureza física e com as relações materiais [Dinglichen] que dela resultam. É apenas uma relação social determinada entre os próprios homens que aqui assume, para eles, a forma fantasmagórica de uma relação entre coisas. Desse modo, para encontrarmos uma analogia, temos de nos refugiar na região nebulosa do mundo religioso. Aqui, os produtos do cérebro humano parecem dotados de vida própria, como figuras independentes que travam relação umas com as outras e com os homens. Assim se apresentam, no mundo das mercadorias, os produtos da mão humana. A isso eu chamo fetichismo, que se cola aos produtos do trabalho tão logo eles são produzidos como mercadorias e que, por isso, é inseparável da produção de mercadorias" (MARX, 2013, p. 147; grifo meu). 
constituir, entretanto, um campo de subjetivação - em que virtudes podem ser obtidas em uma esfera concreta, tecida pelo sujeito na lida com os fantasmas forjados pela cultura.

Assim, o que verificamos com o avanço do poder capitalista é a produção de subjetividades que buscam consumir tudo, diferentemente da época das disciplinas, em que as instituições família, escola e igreja eram responsáveis pela constituição dos indivíduos, a partir de um jogo político que contava com alguns fatores que hoje foram atravessados pelas forças do poder econômico. Claro, a crise do Estado, do ideal em torno dos sistemas comunista e socialista, fez com que a ideia de liberalismo econômico fosse associada à de liberdade individual. Então, não que as antigas instituições de formação dos indivíduos não sejam atualmente mais legitimadas para formar o indivíduo moderno, mas são cada vez mais governadas pelo poder econômico. Se a ideia de administração pública perdeu credibilidade, cada vez mais nas sociedades atuais, para a iniciativa privada, é importante que se pense em um espaço para se constituirem subjetividades, pois estamos correndo o risco de um esvaziamento cada vez maior dos sujeitos, devido à legitimação do ideal de liberdade agregado à ideia de liberdade econômica, que ganha força nesse jogo de forças no capitalismo.

O que podemos pensar a partir do estudo de Nietzsche é que, se as garras do capitalismo ganharam tanta força, elas se uniram a um grupo de forças já ativo, potencializando-se ainda mais, pois, recorrendo à ideia do filósofo sobre a força que a relação entre comprador e vendedor exerce nos modos de troca da nossa civilização, já que sempre esteve presente em qualquer forma de civilização de que obtivemos conhecimento, acabam por instaurar sentimentos, e até mesmo constituir domínios de saberes, que demarcam uma superioridade da espécie humana no que se refere aos outros animais:

O sentimento de culpa, da obrigação pessoal, [...] teve origem, como vimos, na mais antiga e primordial relação pessoal, na relação entre comprador e vendedor, credor e devedor: foi então que pela primeira vez defrontou-se, mediu-se uma pessoa com outra. Não foi ainda encontrado um grau de civilização tão baixo que não exibisse algo dessa relação. Estabelecer preços, medir valores, imaginar equivalências, trocar - isso ocupou de tal maneira o pensamento do homem, que num certo sentido constituiu o pensamento: aí se cultivou a mais velha perspicácia, aí se poderia situar o primeiro impulso do orgulho humano, seu sentimento de primazia diante de outros animais. Talvez a nossa palavra "Mensch" (manas) expresse ainda algo desse sentimento de 
si: o homem [Mensch, em alemão] designava-se como o ser que mede valores, valora e mede, como "o animal avaliador". Comprar e vender, juntamente com seu aparato psicológico, são mais velhos inclusive do que os começos de qualquer forma de organização social ou aliança: foi apenas a partir da forma mais rudimentar de direito pessoal que o germinante sentimento de troca, contrato, débito [Schuld], direito, obrigação, compensação foi transposto para os mais toscos e incipientes complexos sociais (em sua relação com complexos semelhantes), simultaneamente ao hábito de comparar, medir, calcular um poder e outro. O olho estava posicionado nessa perspectiva; e com a rude coerência peculiar ao pensamento da mais antiga humanidade, pensamento difícil de mover-se, mas inexorável no caminho escolhido, logo se chegou à grande generalização: "cada coisa tem seu preço, tudo pode ser pago" - o mais velho e ingênuo cânon moral, a justiça, o começo de toda "bondade", toda "equidade", toda "boa vontade", toda "objetividade" que existe na terra. Nesse primeiro estágio, justiça é a boa vontade, entre homens de poder aproximadamente igual, de acomodar-se entre si, de "entender-se" mediante um compromisso - e, com relação aos de menor poder, forçá-los a um compromisso entre si (2007, p. 59; grifos do autor).

Sendo assim, não podemos destacar o sistema capitalista como um simples esquema econômico que se alojou na nossa sociedade no lugar de outro. $\mathrm{O}$ capitalismo pode ser visto, a partir dessa colocação de Nietzsche, como se fosse uma espécie de avesso da moral, como se estivesse esquivado dos desejos humanos, de suas vontades, enfim, das questões em jogo que implicam os sujeitos. O que queremos afirmar aqui é que não existe um aparelho de trocas abstrato, ele vem carregado de elementos próprios às trocas, às práticas estabelecidas, para a obtenção de alguma coisa no final das contas. E o "desejo de consumo" se apresenta para o indivíduo como se fosse sua própria construção, seu desejo de obter tal ou qual satisfação, mas não é. O poder capitalista se ancora em um modelo de sujeito bem demarcado, fragmentado, sem acesso a modos de se potencializar, desorientado, portanto, pois, em vez de dirigido para si mesmo, encontra-se voltado para as promessas de satisfação "contidas" nos objetos fetiche do capitalismo. É o modelo de sujeito fabricado e explorado pelo biopoder.

\subsection{A biopolítica e o biopoder}

A biopolítica é a noção que vem compreender a transição do poder do rei para o corpo dos indivíduos. O poder do soberano era representado sobre o corpo dos indivíduos, a transgressão a esse tipo de poder retornava sobre o corpo de cada indivíduo de modo aparente, sob a forma do suplício como espetáculo. Com a queda do Estado monárquico, outras formas de poder são inauguradas, e a biopolítica vai 
dizer desse tipo de poder invisível que faz com que os indivíduos se sintam livres, como se não tivessem sendo moldados para agirem de acordo com determinados tipos de poder estabelecidos por um Estado onipresente e pelo conjunto social, que exige que o repertório de comportamentos seja produzido e reconhecido por meio dos parâmetros e gabaritos disponíveis e legitimados. Essa falsa percepção que o indivíduo tem de que é dono do próprio corpo e que se conduz mentalmente com autonomia parece se dar pelo fato de que a biopolítica age na face mais animalizada e fisiológica do corpo.

O corpo da disciplina, o corpo que atende às normas urdidas por esse novo poder, tem a sua energia fundida às normas sociais ou jurídicas, tornando-se, desse modo, normatizado. Numa sociedade que organiza os corpos a partir de um processo de sujeição às normas, vão se forjando as subjetividades, ancoradas nesse modelo normativo, que, por sua vez, vão se nutrir dos saberes advindos da ciência, configurando formas de subjetividade apoiadas nos enunciados da ciência para formular os discursos dos sujeitos sobre eles mesmos no que diz respeito à questão do cuidado de si. Sendo assim, no nosso modelo de sociedade, é o psiquiatra que diz a verdade do louco, o criminalista a verdade do criminoso, e o médico que diz sobre a dor e a doença. Esse modelo de sujeito que se apoia nos saberes científicos supõe que tais saberes dão conta da sua existência, já que enxerga o sofrimento pelas lentes da doença e da morte. A dor psíquica, as dores inevitáveis da vida passam a ser vistas pelo prisma da analgesia, sempre em uma demanda para serem apagadas, como se não fossem úteis para nada. $\mathrm{Na}$ verdade, por fazerem parte da experiência subjetiva das pessoas, se admitidas junto com todos os outros afetos, poderiam dar algum sentido à experiência de cada um. A quebra dos preconceitos, por exemplo, pode ser capaz de transfigurar desafetos em afetos; no lugar do desprezo pelo diferente, a abertura de possibilidade de aproximação e a construção de múltiplas maneiras de convívio e construção de novas maneiras de olhar para si e para o outro. Esse tipo de abordagem a partir dos afetos estaria relacionado à ideia de uma política dos afetos para lidar com a existência no que diz respeito às facetas de alegria e satisfação, mas também de dor e frustração.

Todavia parece que, junto com os avanços da ciência, houve uma hipertrofia das promessas de um modelo de existência "prática", uma expectativa em torno das descobertas advindas das tecnologias científicas, como se elas pudessem revelar, no caso do domínio da medicina, os locais do cérebro em que é possível administrar 
doses certas de remédios para nos livrar das dores da existência. O indivíduo, nesse contexto, se apresenta cada vez mais passivo diante da ideia de uma ciência promissora capaz de salvar os indivíduos dos problemas mais difíceis da existência, principalmente da morte. O panorama é que os indivíduos estão se tornando cada vez mais manipuláveis por esses discursos da ciência, que apresentam uma lógica restritiva principalmente no que diz respeito à subjetivação. Essa sujeição vem como resultado da biopolítica, do corpo da disciplina, que ganha robustez com a afirmação do poder sobre a vida e toda uma aceitação dos saberes delineados nesse sentido. Essa tecnologia de organização dos indivíduos no corpo social, essa biopolítica configura um biopoder cuja dimensão técnica ganha destaque sobre outras possibilidades de fazer política, pois os indivíduos passam a esperar mais da ciência e dão menos de si próprios. 


\section{A Aufklärung kantiana e o acesso à verdade}

A fé sempre é mais desejada, mais urgentemente necessitada, quando falta a vontade: pois a vontade é, enquanto afeto de comando, o decisivo emblema da soberania e da força. Ou seja, quanto menos sabe alguém comandar, tanto mais anseia por alguém que comande, que comande severamente - por um deus, um príncipe, uma classe, um médico, um confessor, um dogma, uma consciência partidária. De onde se concluiria, talvez, que as duas religiões mundiais, $o$

budismo e o cristianismo, podem dever sua origem, e mais ainda a súbita propagação, a um enorme adoecimento da vontade. E assim foi na verdade: ambas as religiões depararam com a exigência de um "tu deves", alçada até o absurdo pelo adoecimento da vontade e indo até o desespero; ambas ensinaram o

fanatismo em épocas de afrouxamento da vontade, com isso proporcionando a muitos um apoio, uma nova possibilidade de querer, um deleite no querer. Pois o fanatismo é a única "força de vontade" que também os fracos e inseguros podem ser levados a ter, como uma espécie de hipnotização de todo o sistema sensório-

intelectual, em prol da abundante nutrição (hipertrofia) de um único ponto de vista e sentimento, que passa a predominar - o cristão denomina sua fé. Quando uma pessoa chega à convicção fundamental de que tem de ser comandada, tornase "crente"; inversamente, pode-se imaginar um prazer e força na autodeterminação, uma liberdade da vontade, em que um espírito se despede de toda crença, todo desejo de certeza, treinado que é em se equilibrar sobre tênues cordas e possibilidades e em dançar até mesmo à beira de abismos. Um tal espírito seria o espírito livre por excelência.

Friedrich Nietzsche, A gaia ciência

Kant, em uma publicação em um jornal da época, desenvolve um texto que, por fazer parte da esfera pública, já que se tratava de um jornal, acaba correspondendo ao ponto de vista de Foucault no que diz respeito ao papel do filósofo, pois, para Foucault, o filósofo pode lançar mão de recursos no espaço público a partir do envolvimento com questões do campo social que lhe causem alguma estranheza, inquietação, ou seja, que o conduza a tentar construir algum recurso de entendimento da situação em questão. ${ }^{13} \mathrm{O}$ seu recorte da questão kantiana da Aufklärung decorre da resposta de Kant a uma pergunta elaborada por

\footnotetext{
13 “Quando, nos dias de hoje, um jornal propõe uma pergunta aos seus leitores, é para pedir-lhes seus pontos de vista a respeito de um tema sobre o qual cada um já tem sua opinião: não nos arriscamos a aprender grande coisa. No século XVIII, se preferia interrogar o público sobre problemas para os quais justamente ainda não havia resposta. Não sei se era mais eficaz: era mais divertido" (FOUCAULT, 2008, p. 335). Foucault não deixa de dar lugar ao prazer, ele se coloca na sua pesquisa, não em nome de uma eficácia, e sim, simplesmente, de um impulso de ir e do prazer de ter o que dizer sobre as coisas que encontra. Podemos entender que esse movimento ilustra seu interesse pelo campo da subjetivação.
} 
um leitor. ${ }^{14}$ Ou seja, a pergunta sobre a Aufklärung e a sua resposta são formuladas no espaço público, enquanto abertura de interlocução, não se restringindo necessariamente a determinada instituição. Ele marca que o seu recorte de Kant é o do autor em diálogo com o público sobre questões que dizem respeito ao tecido social. Kant precisa que a posição de quem lê, seu status de sujeito, interfere na apreensão e transmissão daquilo que se organiza na cultura. E é esse aspecto que nos interessa tratar brevemente neste segundo capítulo - o nosso espanto, decorrente da constatação do fenômeno de objetivação do sujeito na nossa época, nos leva a conferir com atenção a pesquisa sobre a subjetivação, estruturada por Foucault, principalmente diante do fato de que, na nossa cultura, o sujeito que resiste vai investir em elementos voltados para si próprio, que fujam a esse modelo de sujeito presente no mundo atual que se produz enquanto objeto que consome, ao mesmo tempo em que é objeto de consumo. O sujeito, nesse modelo, aparece preso a um circuito de existência em que não há espaço para que ele se produza em um plano de existência que aqui estamos propondo como uma espécie de "campo de verdade do sujeito". No texto de Kant podemos encontrar uma saída para sustentar essa ideia.

O texto sobre a Aufklärung tem a marca de tratar especialmente da concepção de tempo como pura atualidade, além de indicar que a saída pela qual Kant a explica seria um processo que nos libertaria do estado de minoridade. Essa saída - Ausgang - se caracterizaria pela modificação da relação preexistente entre a vontade (quando

\footnotetext{
14 “A psicologia do século XIX herdou da Aufklärung a preocupação de alinhar-se com as ciências da natureza e de encontrar no homem o prolongamento das leis que regem os fenômenos naturais. Determinação de relações quantitativas, elaboração das leis que se apresentam como funções matemáticas, colocação de hipóteses explicativas, esforços através dos quais a psicologia tenta aplicar, não sem sacrifício, uma metodologia que os lógicos acreditaram descobrir na gênese e no desenvolvimento das ciências da natureza. Ora, foi o destino dessa psicologia, que se queria conhecimento positivo, apoiar-se sempre sobre dois postulados filosóficos: que a verdade do homem está exaurida em seu ser natural e que o caminho de todo conhecimento científico deve passar pela determinação de relações quantitativas, pela construção de hipóteses e pela verificação experimental. Toda a história da psicologia até meados do século XX é a história paradoxal das contradições entre esse projeto e esses postulados; ao perseguir o ideal de rigor e de exatidão das ciências da natureza, ela foi levada a renunciar aos seus postulados; ela foi conduzida por uma preocupação de fidelidade objetiva em reconhecer na realidade humana outra coisa que não um setor da objetividade natural, e em utilizar para reconhecê-lo outros métodos, diferentes daqueles de que as ciências da natureza poderiam the dar o modelo. Mas o projeto de rigorosa exatidão que a levou, pouco a pouco, a abandonar seus postulados tornou-se vazio de sentido quando esses mesmos potulados desapareceram: a ideia de uma precisão objetiva e quase matemática no domínio das ciências humanas não é mais conveniente se o próprio homem não é mais da ordem da natureza. Portanto, é a uma renovação total que a psicologia obrigou a si própria no curso de sua história; ao descobrir um novo status do homem, ela se impôs, como ciência, um novo estilo" (FOUCAULT, 2002a, pp. 133-4).
} 
algo ou alguém toma o lugar de decisão pelo indivíduo), a autoridade e o uso da razão. O nosso estado de minoridade se revela, para Kant, por tomarmos o livro, por exemplo, no lugar do entendimento, o orientador espiritual, no lugar da consciência, e o médico, como aquele que decide, em nosso lugar, a nossa dieta. Ele diz que há uma saída para essa posição subjetiva, que se diz racional, mas que, na verdade, não faz um real uso da razão. A Ausgang seria uma saída ambígua, por se caracterizar como um fato, um processo em vias de se desenrolar, ao mesmo tempo em que se apresenta como tarefa e obrigação.

Parece que esse problema da minoridade pode ser visto em alguns pontos, presentes na nossa época, já que os discursos científicos reinam em nossa cultura e os indivíduos considerados leigos se apresentam a partir de uma posição passiva em relação aos saberes legitimados e seus representantes. E o que vemos a partir do trabalho do poder-saber-subjetividade em Foucault é que a saída de uma posição subjetiva passiva é muito trabalhosa, já que se dá numa dimensão de luta e resistência ininterruptas. Mas, para nós, resistir e dar forma a essas forças de resistência conferem um brilho à existência. Por exemplo, em vez de nos contentarmos apenas em reclamar dos preços das mercadorias, dos impostos que somos obrigados a pagar, da violência a que somos submetidos todos os dias, podemos refletir sobre o nosso mundo de maneira mais complexa, questionando, inclusive, as informações que a mídia, interessada em formar determinada opinião pública, apresenta. Por exemplo, existem pesquisas da ONU que apontam para os danos ambientais que a agropecuária provoca no meio ambiente, que relacionam o ramo de criação de gado e o consumo de carne ao investimento em uma publicidade que desvia o foco dos problemas ambientais para a queima dos combustíveis fósseis - carvão, gás natural, óleo etc. Até porque a associação da agressão do meio ambiente a esse tipo de prática parece bem óbvia e inquestionável. ${ }^{15}$ Lembremos, no entanto, da noção de segredo elaborada por Foucault. Foucault ensina que, se os saberes estão relacionados às práticas de poder, cairemos num equívoco se adotarmos prontamente os discursos formulados pelos especialistas, já que eles estão inseridos em uma trama política articulada aos interesses do capital, e que, para se manterem no mercado, e até mesmo se manterem vivos, não podem emitir

\footnotetext{
${ }^{15}$ Dados provenientes do documentário Cownpiracy: o segredo da sustentabilidade, feito para o Netflix.
} 
qualquer discurso, mas apenas apresentar aqueles que podem ser proferidos, enquanto determinados discursos não podem ser sequer citados. Assim funcionam os jogos de verdade (poder-saber). No Brasil não podemos desprezar o número de ativistas que tentaram enfrentar esquemas brutais de exploração da Floresta Amazônica, como, por exemplo, Chico Mendes, seringueiro, sindicalista e ativista político e ambiental brasileiro, assassinado em dezembro de 1988, e a freira Doroth Stang, americana naturalizada brasileira que viveu na região do Xingu desde os anos 1970, dedicando-se a projetos de desenvolvimento sustentável, assassinada em fevereiro de 2005.

Mais um exemplo diz respeito a pesquisas que apontam para o problema da fome mundial no nosso mundo pela ótica de um genocídio, pois afirmam que, com a tecnologia que a ciência edificou, não haveria mais por que haver fome no planeta hoje. Essas pesquisas problematizam a lógica do mercado financeiro e assinalam que a ganância de determinados grupos financeiros por lucro produz o esvaziamento de possibilidades de atender as necessidades de grupos de indivíduos nas mais diversas partes do planeta. ${ }^{16}$

\subsection{O sujeito na nossa cultura: um espectador passivo em face dos acontecimentos}

A filosofia, como poder do pensamento separado e pensamento do poder separado, jamais conseguiu, por si só, superar a teologia. A técnica espetacular não dissipou as nuvens religiosas em que os homens haviam colocado suas potencialidades, desligadas deles: ela apenas os ligou a uma base terrestre. Desse modo, é a vida mais terrestre que se torna opaca e irrespirável. Ela já não remete para o céu, mas abriga dentro de si sua recusa absoluta, seu paraíso ilusório. O espetáculo é a realização técnica do exílio, para o além, das potencialidades do homem; a cisão consumada no interior do homem.

Guy Debord, A sociedade do espetáculo

A fim de explorarmos um pouco mais a ideia da relação do sujeito consigo próprio no tocante ao resgate alguns elementos do campo da epiméleia heautôu que dizem respeito à ocupação do sujeito consigo mesmo, da volta do olhar do sujeito

\footnotetext{
${ }^{16}$ A esse respeito, Jean Ziegler, relator da ONU para o direito à alimentação entre 2000 e 2008, publicou o livro Destruição em massa: geopolítica da fome (Cortez, 2012).
} 
para si, vamos nos ater a algumas breves linhas sobre a célebre obra $A$ sociedade do espetáculo: comentários sobre a sociedade do espetáculo, de Guy Debord, escrita nos anos 1960. É sabido o quanto as ideias lançadas nesse livro foram abraçadas pelos manifestantes de Maio de 68. Para fins de estruturação desta tese, pinçamos somente alguns pontos cruciais, que nos parecem fundamentais para problematizarmos o tema do sujeito no nosso tempo. Isso porque, para nós, em uma pesquisa sobre o tema do sujeito não cabe dispensar a relação entre as modernas condições de produção e os efeitos sobre os modos de subjetivação.

Nessa obra, Debord elabora a ideia de "espetáculo" como uma espécie de configuração moderna que vem ocupar o lugar da ilusão religiosa, passando a produzir modos de vida que, no âmbito dessas modernas condições de produção, deslocam os fluxos de vida, no contexto das relações concretas de trabalho, para sua fixação em um âmbito imagético.

Suas análises revelam uma preocupação sobre os efeitos que o vínculo do sujeito com a mercadoria produz nas relações sociais. Isso tudo considerando não só a relação dos indivíduos uns com os outros, mas dos indivíduos consigo mesmos. Debord se atém ao problema da influência do capitalismo sobre as formas de sociabilidade no nosso tempo, oferecendo uma análise que traz alguns elementos que vêm nos auxiliar a pensar o tema do sujeito por essa via em que estamos nos situando: o trato do tema da relação do sujeito com a verdade, a partir da pesquisa de Foucault em torno da noção de epiméleia heautoû. Isso porque essa noção, que podemos traduzir por cuidado de si, nos remete a uma reflexão sobre a ideia de relação do sujeito consigo mesmo no sentido da formulação de um campo de subjetivação no qual a ocupação consigo mesmo consista numa atenção especial ao conjunto de hábitos de cada um que incluem os mecanismos de defesa e de fuga que produzimos na vida desde muito cedo diante das dificuldades, frustrações e limitações próprias à nossa condição. Diante da tendência que habitualmente desenvolvemos de nos desviar dos acontecimentos mais difíceis da vida, a subjetivação funcionaria como a elaboração de um campo de forças de resistência, não no sentido de fuga da dor, mas de aprendizado a partir da criação de recursos, do enfrentamento das adversidades da vida. Esse campo diz respeito à esfera da espiritualidade, não porque se restrinja a elementos religiosos, mas porque se trata de um campo que resiste a um trato unicamente material. $\mathrm{O}$ campo que Debord delineia trata do estágio de acumulação capitalista no qual nos inserimos hoje, ao 
mesmo tempo, como sujeitos produtores e consumidores obsessivos de produtos manufaturados. O indivíduo, nesse esquema, segue uma vida norteada por uma mídia que modula diversos estilos de sujeito, que veicula imagens que, por sua vez, vão traduzir os afetos dos indivíduos, como, por exemplo, a ideia de alguém bemsucedido, “descolado", feliz etc. Esse processo produz a reificação do indivíduo, visto que o conduz a um processo de identificação com as imagens produzidas pelo mercado, que visa vender os objetos concretos "fetichizados" associados às ideias de estilos de vida, como, por exemplo, uma série de serviços específicos para cada estilo de vida. Tudo isso altamente investido pela publicidade, que vai produzindo nos indivíduos uma obsessão em aderir a algum tipo de "tribo". Esse investimento, vindo dessa aliança entre mercado e publicidade, produz o descolamento do indivíduo consigo mesmo e com o outro, esvaziando a sua vida das preocupações mais complexas no que diz respeito à vida individual e de conjunto.

A noção de espetáculo nos interessa no âmbito desta tese por dialogar com a ideia de alienação, desenvolvida por Marx em Manuscritos econômico-filosóficos, segundo a qual as forças humanas seriam direcionadas, no contexto de um processo de acumulação capitalista, para seu encerramento em um esquema de produção e consumo no qual os artigos manufaturados "passam a ganhar vida", operando como um atrativo simbólico por meio daquilo que o autor designou por "fetichismo da mercadoria". O fetiche da mercadoria opera obscuramente sobre a relação do sujeito com os produtos que consome, pois exerce forte influência na relação do sujeito consigo mesmo e com os outros, já que atribui valores não só aos objetos produzidos para o consumo, mas também aos sujeitos que têm ou não têm esses objetos. Tanto a noção de alienação como a de fetichismo da mercadoria, elaboradas por Marx, apontam para a complexidade da questão do sujeito, do vínculo do sujeito com os elementos do campo social do qual faz parte, além da relação dos sujeitos consigo mesmos e entre si.

Debord, a partir da ideia marxista de alienação, circunscreve o problema da separação e da reificação da vida humana, apontando para a reificação como um efeito imaginário, decorrente de um processo mais amplo de separação, relativo ao espírito humano. A ideia de espetáculo se traduz como uma forma de dominação burguesa sobre o proletariado que se tornou um poder ainda mais complexo, se alastrando para todo o corpo social. Para Debord, a resistência à alienação se apresentaria como uma estratégia de combate a esse tipo de poder, que consome as 
forças humanas para sustentar-se a si próprio, traço presente em qualquer forma de poder. Logo Debord aponta para uma transformação significativa no que diz respeito à vida humana nas sociedades modernas: no lugar do vivido, entrou em cena uma representação da vida e, com isso, um acúmulo de espetáculos. Segundo Debord:

As imagens que se destacaram de cada aspecto da vida fundem-se num fluxo comum, no qual a unidade dessa mesma vida já não pode ser restabelecida. A realidade considerada parcialmente apresenta-se em sua própria unidade geral como um pseudomundo à parte, objeto de mera contemplação. A especialização das imagens do mundo se realiza no mundo da imagem autonomizada, no qual o mentiroso mentiu para si mesmo. O espetáculo em geral, como inversão concreta da vida, é o movimento autônomo do não vivo (1997, p. 13).

A perspectiva que Debord lança é que, com o domínio capitalista, após a passagem pela luta de classes entre a classe burguesa e a operária, no qual esta é sobrepujada por aquela, a alienação passa a exercer uma ação sobre a vida social que captura aquilo que faz parte da dimensão das produções mais espontâneas no que se refere ao aspecto humano, transformando tudo em representações falsas e artificiais. Em suas palavras:

Para descrever o espetáculo, suas formações, suas funções e as forças que tendem a dissolvê-lo, é preciso fazer uma distinção artificial de elementos inseparáveis. Ao analisar o espetáculo, fala-se de certa forma a própria linguagem do espetacular, ou seja, passa-se para o terreno metodológico dessa sociedade que se expressa pelo espetáculo. Mas o espetáculo nada mais é que o sentido da prática total de uma formação econômico-social, o seu emprego do tempo. É o momento histórico que nos contém (1997, p. 16).

O espetáculo nos encerra no modo capitalista de produção, nos atraindo de tal maneira que se torna difícil a abertura de um campo de reflexão. A nosso ver, esse grande sentido não passa de uma espécie de superprojeção das inevitáveis frustações humanas que se dão no contato dos indivíduos com a realidade. Não é à toa que, se observarmos com atenção, as campanhas publicitárias associam elementos que não teriam, a princípio, qualquer relação. Elas ligam determinadas ideias a outras - de acordo com um certo senso comum, que aponta para determinados padrões de comportamento e desejo -, operando sobre a produção do desejo das pessoas, inventando o que as pessoas querem, além de convencê-las a 
partir de estratégias que operam sobre esse desejo, forjado pela associação entre publicidade e indústria.

Trata-se de um campo forjado por um acúmulo de espetáculos, a partir de um processo de projeção de imagens que se separam das condições concretas de existência e de seus problemas. Assim, o espetáculo como "inversão concreta da vida", como o movimento autônomo do não vivo, se aproxima da noção nietzschiana de ideal ascético, no sentido que recortamos para o nosso trabalho: diante da falta de sentido para a vida, o ideal ascético se estabelece com toda força, e conta fundamentalmente com a negação da vida. A pesquisa de Debord nos ajuda a entender que, diante do problema do ideal ascético, a vida humana acabou avançando em uma direção que dá cada vez mais espaço para um arcabouço imaginário e instável. Assim, ele nos alerta para o fato de que o espetáculo não é simplesmente um apelo à imagem, ao seu caráter sedutor apenas, como se estivesse referido a uma espécie de produto das "técnicas de difusão das imagens". Trata-se de uma visão de mundo que se objetivou a partir do cessamento do fluxo vital, que passou a se estagnar em representações. Para Debord:

O espetáculo se apresenta como uma enorme positividade, indiscutível e inacessível. Não se diz nada além de "o que aparece é bom, o que é bom aparece". A atitude que, por princípio, ele exige é a da aceitação passiva, que, de fato, ele já obteve por seu modo de aparecer sem réplica, por seu monopólio da aparência (1997, p. 16).

Deparamos mais uma vez com alguns elementos que dizem respeito a uma problematização do tema da subjetivação na nossa época: a questão da reificação do sujeito, que pode ser entendida, no cenário de sua objetivação, como um problema resultante do desvio do sujeito no que diz respeito à ocupação consigo e sua captura pelo poder capitalista. O sujeito de nossa época não parece estar atento ao problema da escravidão promovida pelas nossas próprias paixões, afinal, uma sociedade do espetáculo não teria lugar se o ideal ascético já não tivesse implantado no campo da subjetivação um "hábito" de esvaziar-se a partir de um gesto de recusa da vida. O mercado seria uma espécie de imperador do nosso tempo. Para Debord:

O caráter fundamentalmente tautológico do espetáculo decorre do simples fato de seus meios serem, ao mesmo tempo, seu fim. É o sol que nunca se põe no império da passividade moderna. Recobre toda a superfície do mundo e 
está idefinidamente impregnado de sua própria glória (1997, p.17).

Se o espetáculo não deve ser concebido como um mero conjunto de imagens, já que trata de um modo de se estabelecerem relações sociais pelo qual as pessoas vão criar vínculos por meio das imagens, faz-se urgente refletirmos que, na nossa época, o mercado, por tudo que o caracteriza, não vai abrir espaço para uma discussão ética. Essa seria uma tarefa a ser empreendida pelos sujeitos que se propõem a pensar seu tempo. Para nós, o cerne do problema da captura pelo mercado está relacionado com a tendência que os indivíduos têm de se projetar em uma espécie de fuga de sua própria realidade. As representações investidas pelo capitalismo criam aberrações, como a ideia de individualismo associada a uma imagem de potência, que, enfim, nos conduzem para cada vez mais longe de uma sociedade que se proponha a refletir sobre tantos problemas de base.

\subsection{A abordagem da Antiguidade pelo ponto de vista do genealogista: para além da questão do método, uma saída}

Nunca é demais lembrar que, em todo o seu trabalho, Foucault, em vez de se limitar a aludir a questões já conhecidas, ou, ainda, se reportar a elas dando-lhes outro enfoque, engendrou novos pontos de vista para tratar dos problemas com os quais se deparava. O ângulo pelo qual Foucault formula suas questões tem a especificidade de implicá-las no jogo de forças intrínseco ao conjunto social, já que este é concebido nos moldes de uma microfísica do poder, de acordo com a qual haveria um poder invisível atuante nas instituições reconhecidas como de formação dos indivíduos da nossa sociedade.

Divergindo de uma perspectiva formada pelo senso comum, que procura engendrar os problemas segundo um marco inicial, segundo sua origem (Ursprung), Foucault se permite fabricá-los, abordando-os por novos prismas. No célebre texto Nietzsche, a genealogia e a história, ele problematiza o termo Ursprung à luz da obra de Nietzsche, mostrando que o filósofo tenta evitar o problema da origem, abrindo o termo e introduzindo outros, conferindo maior privilégio à ideia de um ponto de partida do que a de uma origem como essência. Por exemplo, os termos Herkunft, Entestehung e Erbschaft são usados por Nietzsche em vários momentos de sua obra. Foucault mostra que Herkunft e Entestehung, geralmente traduzidos por origem, têm significados mais amplos, 
representando de maneira mais satisfatória o objeto da genealogia do que o termo Ursprung.

Herkunft trata do pertencimento a um grupo no sentido dos laços de sangue entre seus membros, indaga a estirpe. Assim, a análise da Herkunft traz à baila questões de raça e tipo social, não pretendendo apontar características gerais, que, ao serem encontradas, indicariam pontos de semelhança entre os indivíduos. Tratase de outra abordagem - deslindar os pontos mais sutis, as singularidades que podem se entrecruzar e constituir uma trama complexa. Para Foucault:

Longe de ser uma categoria da semelhança, tal origem permite ordenar, para colocá-las à parte, todas as marcas diferentes: os alemães imaginam ter chegado ao extremo de sua complexidade quando disseram que tinham a alma dupla; eles se enganaram redondamente, ou melhor, eles tentam como podem dominar a confusão das raças de que são constituídos. Lá onde a alma pretende se unificar, lá onde o Eu inventa para si uma identidade ou uma coerência, o genealogista parte em busca do começo - dos começos inumeráveis que deixam essa suspeita de cor, essa marca quase apagada que não saberia enganar um olho, por pouco histórico que seja; a análise da proveniência permite dissociar o Eu e fazer pulular, nos lugares e recantos de sua síntese vazia, mil acontecimentos agora perdidos (FOUCAULT, 1998, p. 20, grifo meu).

A abordagem pela proveniência entende as noções de eu e de origem a partir da proliferação dos acontecimentos, não visando ao fundamento das coisas, mas, sim, causando o abalo desse fundamento, desmistificando a ideia de união e continuidade para mostrar que as coisas ocupam um lugar em um plano de heterogeneidade. Foucault afirma que o traço que melhor define a pesquisa da proveniência é que, em vez de se prestar a encontrar fundamentos, ela se volta para produzir abalos e inquietações - "ela agita o que se percebia imóvel, ela fragmenta o que se pensava unido; ela mostra a heterogeneidade do que se imaginava em conformidade consigo mesmo" (FOUCAULT, 1998, p. 21).

Nesse mesmo texto, Foucault assinala que Nietzsche, ao usar detalhadamente o termo Herkunft no prefácio de A genealogia da moral quando se ocupa da origem dos preceitos morais, mostra preocupação com o problema da origem. Posteriormente, Nietzsche diria ter reconhecido que aquilo que tinha se proposto a fazer era uma pesquisa de Ursprung. Foucault mostra que Nietzsche vai usar o termo Herkunft para tratar de alguns textos de Humano demasiado humano, voltado para a origem da moralidade, da justiça e do castigo, e que, na Genealogia da moral, 
ele procura marcar uma diferença entre os dois termos, mas, depois, acaba por não mais os deferenciar, usando-os, enfim, de modo análogo.

Foucault entende que o Nietzsche genealogista resiste ao uso do termo Ursprung, ou seja, ao delineamento de uma pesquisa da origem, porque, por esse ângulo, pode-se incorrer no equívoco de tentar alcançar uma essência exata do objeto, como se as coisas pudessem existir em sua mais pura possibilidade, tendo uma forma própria e anterior a qualquer acontecimento. Em sua obra, Nietzsche se atém a desmistificar a ideia de origem, e Foucault, ao escrever Nietzsche, a genealogia e a história, empreende uma perspectiva da genealogia que mostra que as coisas se constituem a partir dos acontecimentos, do acaso, e não de uma lógica que, no fundo, encobriria uma essência primordial. Para Foucault:

Se interpretar era colocar lentamente em foco uma significação oculta na origem, apenas a metafísica poderia interpretar o devir da humanidade. Mas, se interpretar é se apoderar, por violência ou sub-repção, de um sistema de regras que não tem em si significação essencial, e lhe impor uma direção, dobrá-lo a uma nova vontade, fazê-lo entrar em um outro jogo e submetê-lo a novas regras, então o devir da humanidade é uma série de interpretações. E a genealogia deve ser a sua história: história das morais, dos ideais, dos conceitos metafísicos, história do conceito de liberdade ou de vida ascética, como emergências de interpretações diferentes. Trata-se de fazê-las aparecer como acontecimentos no teatro dos procedimentos (FOUCAULT, 1998, p. 26, grifo meu).

A genealogia apreende o corpo como lugar de inscrição dos acontecimentos, de um Eu cindido, inacabado, lançado no devir da história. Pensar a proveniência a partir da genealogia permite um modo de apreensão do corpo que o libere do enfoque do erro como culpa, já que aquilo que o corpo faz é marcado inevitavelmente pela história. Sendo assim, ele não pode ser visto apartado do processo, muito menos como culpado pelos erros da história - os corpos dos indivíduos marcados, inscritos pela história, têm sua materialidade engendrada pelo devir histórico:

O corpo - e tudo o que diz respeito ao corpo, a alimentação, o clima, o solo é o lugar da Herkunft: sobre o corpo se encontra o estigma dos acontecimentos passados do mesmo modo que dele nascem os desejos, os desfalecimentos e os erros; nele também eles se atam e de repente se exprimem, mas nele também eles se desatam, entram em luta, se apagam uns aos outros e continuam seu insuperável conflito (FOUCAULT, 1998, p. 22). 
Longe da ideia de que se pode alcançar coisas passadas por um recuo no tempo, a proveniência mantém o acontecimento passado na dispersão mesma que lhe é singular. Trata-se de demarcar os acidentes, os desvios quase insignificantes, ou, ao contrário, as inversões completas, as falhas e os erros de cálculo aos quais atribuímos valor, concluindo que só é possível abarcar dos acontecimentos a exterioridade do acidente, jamais a verdade e o ser.

No que se refere à Entestehung, ela seria o ponto de surgimento, qualificando o princípio e a lei singular de um aparecimento, o que remete ao mesmo problema que se tem quando se quer atribuir uma continuidade para a proveniência. A Entestehung não pode ser assimilada à ideia de finalidade, como se as coisas nascessem com determinado fim a ser revelado. O genealogista resgata o jogo casual das dominações, nunca a potência antecipadora de um sentido.

Para finalizar, vale lembrar que o genealogista necessita da história para afastar a ficção própria à ideia de origem, tão arraigada em nosso modo de pensar a história. Ao se liberar da busca pela origem, o genealogista se permite atentar para os acontecimentos históricos a partir de seus abalos e imprevistos. Para Nietzsche, a metafísica crê em uma identidade distante, e por isso inalcançável, enquanto o genealogista se move em direção aos abalos inerentes a qualquer tipo de acontecimento, enfrentando a realidade concreta, que mostra que tudo o que existe, tudo aquilo a que atribuímos valor nasce dos mais diversos acidentes históricos, e não de algo previsto e bem calculado. Para o genealogista, naquilo que se conhece não se encontra nem a verdade nem o ser. Nas palavras de Foucault:

Se o genealogista tem o cuidado de escutar a história em vez de acreditar na metafísica, o que é que ele aprende? Que atrás das coisas há "algo inteiramente diferente": não seu segredo essencial e sem data, mas o segredo que elas são sem essência, ou que sua essência foi construída peça por peça a partir de figuras que lhe eram estranhas. A razão? Mas ela nasceu de uma maneira inteiramente "desrazoável" - do acaso. A dedicação à verdade e ao rigor dos métodos científicos? Da paixão dos cientistas, de seu ódio recíproco, de suas discussões fanáticas e sempre retomadas, da necessidade de suprimir a paixão - armas lentamente forjadas ao longo das lutas pessoais. E a liberdade, seria ela na raiz do homem o que o liga ao ser e a verdade? De fato, ela é apenas uma "invenção das classes dominantes". O que se encontra no começo histórico das coisas não é a identidade ainda preservada da origem é a discórdia entre as coisas, é o disparate (FOUCAULT, 1998, p. 18). 
Nossa ideia é que, a partir dessa breve passagem pela genealogia, possamos justificar de que maneira, daqui por diante, faremos uso do material contido no curso de 1982 para traçar linhas de pensamento sobre algumas questões relativas ao sujeito inventado por certas práticas de si antigas que contribuem para levantarmos alguns pontos de reflexão sobre o tema da subjetivação no nosso mundo, onde as subjetividades são pensadas por discursos relacionados a práticas de dominação capitalistas que urgem ser problematizadas. Se delinearmos tais questões apenas com os recursos dos quais dispomos na nossa época, se restringirmos a apreensão do sujeito como objeto pelo enfoque da consciência, acabaremos presos a um recorte muito limitado, que não poderá nos ajudar a enfrentar os problemas deste mundo tão pessimista e niilista. 


\section{O sujeito na Antiguidade era capaz de formular sua verdade: a epiméleia heautoû}

Pela perspectiva da genealogia, Foucault situa a questão do sujeito no panorama das práticas relacionadas à epiméleia heautoû, ao cuidado de si, em uma manobra original, permitindo-se explorar o campo da subjetivação, outrora estabelecido nesse panorama das práticas de si antigas, e reunindo recursos para enriquecer as questões que levantamos sobre o tema do sujeito na nossa época. Anima-nos traçar uma reflexão sobre o tema em um campo próprio - o da subjetivação -, e não em um domínio como o da ciência, ou qualquer campo de saber delineado a partir da Modernidade. Não que esses domínios devam ser descartados. Longe disso, apostamos que a nossa preocupação em trabalhar o tema do sujeito, exercendo uma crítica ao apanhado cientificista, que acaba tomando-o como objeto - o que alimenta o fenômeno de objetivação do sujeito -, faz-se urgente na nossa época. Mas sabemos do risco que corremos se forjarmos uma abordagem simplista, ao tentar deslocar o sujeito de um campo no qual se encontra tão arraigado: o domínio da consciência. Todavia, A hermenêutica do sujeito, com toda sua densidade e os incontáveis exemplos sobre a influência histórica da epiméleia heautoû experimentada durante longo período da história do Ocidente, vem mostrar que o campo da subjetivação é um domínio não só atual, como também é urgente relançá-lo no nosso tempo, feitos os devidos ajustes aos nossos problemas. Podemos dizer que estamos lidando de maneira intempestiva com o assunto. De acordo com Foucault:

Pode-se objetar que, para estudar as relações entre sujeito e verdade, é, sem dúvida, um tanto quanto paradoxal e passavelmente sofisticado escolher a noção de epiméleia heautô̂, para a qual a historiografia da filosofia, até o presente, não concedeu maior importância. É um tanto paradoxal e sofisticado escolher essa noção, pois todos sabemos, todos dizemos, todos repetimos, e desde muito tempo, que a questão do sujeito (questão do conhecimento do sujeito, do conhecimento do sujeito por ele mesmo) foi originalmente colocada em uma fórmula totalmente diferente e em um preceito totalmente outro: a famosa prescrição délfica do gnôthi seautón ("conhece-te a ti mesmo"). Assim, enquanto tudo nos indica, na história da filosofia - mais amplamente ainda, na história do pensamento ocidental -, que o gnôthi seautón é, sem dúvida, a fórmula fundadora da questão das relações entre sujeito e verdade, por que escolher essa noção aparentemente um tanto marginal, que certamente percorre o pensamento grego, mas à qual parece 
não ter sido atribuído qualquer status particular, a de cuidado de si mesmo, de epiméleia heautoû? (FOUCAULT, 2006a, p. 5).

Deparamos com um traço bem característico da análise foucaultiana - a problematização de temas marginais, de rotas não exploradas, em uma espécie de movimento de contrafluxo da história oficial, mantendo sempre como pano de fundo os recursos advindos das análises do poder-saber, definidas na primeira parte da obra. Isso é observado em todo o trabalho relativo à pesquisa do sujeito antigo desse grupo de filósofos dos séculos I e II da nossa era. Foucault foi à fonte - àquilo que, para nós, é considerado uma verdade, dada como origem -, à articulação do "conhece-te a ti mesmo" como coração do que se concebe como sujeito, donde vai descender o sujeito moderno, nos fazendo lembrar que o "conhece-te a ti mesmo", em sua formulação original, não era considerado o que viria a se tornar depois.

$\mathrm{O}$ estudo da genealogia nos faz entender que o estabelecimento da ideia de que a questão do gnôthi seautón se institui exatamente nos centros gregos, nos termos de uma aparição original, é bem conveniente a um modelo de história linear, que se mostra isenta de fissuras ou dos desvios próprios aos acontecimentos.

Foucault se atém ao momento histórico no qual a epimeléia heautoû se separa do gnôthi seautón, lançando aí toda uma problematização em torno da questão do sujeito da nossa época; e a análise desse curso, a partir da perspectiva genealógica, mostra que podemos vislumbrar a elaboração de um sujeito capaz de se autoproduzir a partir de um processo de subjetivação, como os antigos, já que o sujeito é uma formulação histórica.

Se, cada vez mais, se está dando um enfoque ao sujeito como objeto, isso não quer dizer que não há meios para resistir a esse investimento maciço que, como vimos na primeira parte deste trabalho, está relacionado com o capitalismo. A subjetivação pode abrir um campo de forças provenientes da resistência contra as forças opressoras e que permitem seu desvio para o campo do sujeito, instaurando elementos singulares a um trabalho de subjetivação, ou seja, de emergência de um sujeito formulado por técnicas de si.

O cuidado de si antigo pode ser considerado um recurso imprescindível para tratar o problema do sujeito da nossa época, que tem buscado soluções para sanar as dores da existência fora de seu campo de atuação, fora de si mesmo. Esse estudo de Foucault dialoga com alguns discursos críticos que muitos autores estão fazendo 
nessa direção, ou seja, de que é preciso voltar o olhar para si mesmo. Parece-nos que a constituição de um campo ético pode se fazer a partir do giro do sujeito para ele mesmo. Aliás, essas palavras eram ditas de maneira obstinada por Sócrates: "cuida de ti mesmo", "é preciso que se ocupe consigo mesmo". Vamos passar aos antigos.

\subsection{O âmbito da educação como campo de aplicação do cuidado de si}

\subsubsection{A referência ao diálogo do Alcibíades}

Importante frisar que, se a pesquisa de Foucault sobre o cuidado de si na Antiguidade parte do texto Alcibíades, sua pretensão não era dar conta dessa noção em Platão; tampouco pretendera recompor a história contínua do cuidado de si desde as formulações socrático-platônicas até o cristianismo. $\mathrm{Na}$ linha de pensamento que Foucault apresenta no curso de 1982, no qual se fia no problema do cuidado de si em sua relação com a célebre fórmula do conhece-te a ti mesmo, o texto de Platão é empregado em uma lógica diacrônica, no âmbito de uma história descontínua, sendo articulado a toda uma problemática em torno de algumas transformações desse modelo de cuidado desde a Antiguidade até a nossa época. $\mathrm{O}$ Alcibíades é utilizado como um fragmento pinçado da filosofia clássica e, posteriormente, associado a outros fragmentos históricos da filosofia helenística e romana - período imperial - para indicar algumas transformações importantes das práticas do cuidado de si no âmbito de determinado grupo de filósofos. Assim, deparamos com a formulação de uma linha de pensamento sobre o cuidado de si da Antiguidade nunca realizada até então pela história habitual.

Seguindo o itinerário de Foucault, vamos partir da antiga sentença grega que afirma: "é preciso ocupar-se consigo mesmo" - sentença especificamente lacedemônia. A ocupação consigo mesmo era uma forma de existência atada a privilégios, e não uma prática dos círculos filosóficos - até porque, para os espartanos, a filosofia, o intelectualismo etc. não eram valores muito positivos -, consistindo em um privilégio político, social e econômico. Foucault cita um exemplo, apresentado por Plutarco, que descreve a resposta que Alxândrides, um lacedemônio, um espartano, certa vez teria pronunciado quando submetido à seguinte pergunta: 
Mas, afinal, vós, espartanos, sois um tanto estranhos; tendes muitas terras e vossos territórios são imensos ou, pelo menos, muito importantes; por que não os cultivais vós mesmos, por que os confiais a hilotas? E Alxândrides teria respondido: simplesmente para podermos nos ocupar com nós mesmos (FOUCAULT, 2006a, p. 42).

Como dito anteriormente, o fato de ocupar-se consigo ser um princípio ordinário, geralmente ligado a um privilégio econômico, político e social, evidencia determinados aspectos da história da epiméleia heautoû. Quando Sócrates resgata e assume a epiméleia heautoû como questão, o faz com base nessa tradição. Desse modo, a referência a Esparta se encontra presente desde a primeira formulação do cuidado de si nesse diálogo.

Quando Sócrates interpela Alcibíades, chamando sua atenção para o cuidado consigo, Sócrates, se fosse perguntar-lhe sobre a velha questão clássica da educação grega concernente a Homero - que consistia na seguinte questão: se fosse necessário decidir entre levar a vida adiante sem nenhum brilho ou morrer, qual seria sua opção -, Alcibíades responderia preferir a morte a ter de seguir uma vida que não lhe oferecesse mais do que tinha até então. Alcibíades tinha recursos, um patrimônio significativo, status na cidade, privilégios ancestrais que o colocavam em posição de destaque, além de fazer parte de uma família que empreendia diversos negócios na cidade. Tinha uma grande fortuna e boa descendência: por parte de pai, era eupátrida e, por parte de mãe, era alcmeônida, o que propiciava o convívio com parentes e amigos influentes e ricos.

Além disso, quando perdeu os pais, teve a oportunidade de ter Péricles como tutor. No que diz respeito aos enamoramentos, foi extremamente assediado; no entanto, por ser muito bonito, orgulhoso e arrogante, acabara dispensando todos os homens que se interessavam por ele - tendo restado apenas Sócrates - e, tendo envelhecido, não tinha mais a idade característica de um rapaz que pudesse ser abordado, logo, amado.

Sócrates, contudo, manteve-se interessado, resolvendo dirigir-lhe a palavra. Isso porque ele se preocupava com o que Alcibíades tinha em mente, pois sabia que, não bastando tudo o que a vida lhe proporcionara, ele queria mais. Queria participar do governo da cidade, governar o povo, os outros, transformando o seu status, todo esse mérito, em governo efetivo dele próprio sobre os outros: 
É na medida em que essa intenção está se formando, no momento em que tendo tirado proveito ou recusado aos outros o proveito de sua beleza Alcibíades se volta então para o governo dos outros (após o éros, a pólis, a cidade), é nesse momento que Sócrates ouve o deus que o inspira dizer-lhe que pode agora dirigir a palavra a Alcibíades. É alguém que tem uma tarefa: transformar o privilégio de status, a primazia estatutária, em governo dos outros. Fica claro no texto que é nesse momento que nasce a questão do cuidado de si (FOUCAULT, 2006a, p. 44).

Sócrates reconhece que essa questão do amor por si mesmo e pelos outros aponta para o problema do poder. Diante disso, a importância do cuidado. Como dito acima, Foucault adota o Alcibíades como chave da transformação da noção do cuidado de si, em razão de nele encontrarmos três questões associadas ao cuidado de si na época clássica - a política, a pedagogia e o conhecimento de si -, que, ao serem cotejadas com os textos dos séculos I e II da nossa era, acabam revelando algumas mudanças significativas no que diz respeito a essa noção. A primeira mudança diz respeito ao campo de aplicação do cuidado de si e à demarcação nítida das fronteiras do campo da ocupação consigo mesmo, que, no período clássico, se restringia aos jovens aristocratas designados ao exercício do poder. Ligado a isso está o fato de a ocupação consigo mesmo se traduzir na criação de condições voltadas para o exercício de tal poder de modo virtuoso e sensato. Outra mudança diz respeito à forma, pois o cuidado de si teria como aspecto principal o conhecimento de si, ou seja, a ocupação consigo mesmo ganharia a forma do conhecimento de si mesmo.

Nesse solo do cuidado de si, um processo duradouro vai se efetuar com o advento do Império, repercutindo em significativas transformações desse cuidado. Mais tarde voltaremos a essa questão do tempo, aliás, certamente não assinalado à toa nesse trecho. Veremos que tanto a metanóia cristã quanto a epistrophé platônica exigiam uma mudança súbita para certificar a mudança peculiar a essas práticas. E o cuidado de si, com todo o conjunto de técnicas que o caracteriza - as técnicas de si -, vai passar por uma série de transformações e perdurar por longo período, não saindo totalmente de cena:

Na realidade, é ao cabo de uma longa evolução, já perceptível no interior da obra de Platão, que essas diferentes condições do cuidado de si, expostas no Alcibíades, finalmente desapareceram. Essa evolução, já sensível em Platão, 
prossegue ao longo de toda a época helenística, tendo como elemento portador e, em grande parte, sob o seu efeito, todas aquelas filosofias, cínica, epicurista, estoica, que se apresentaram como artes de viver (FOUCAULT, 2006a, p. 102).

Uma das transformações observadas é a passagem de tais práticas do domínio do indivíduo jovem, aristocrata, para a esfera mais geral de todos os indivíduos no decorrer da vida como um todo, desfazendo-se a demarcação rígida de um status estabelecido. O objetivo traçado no Alcibíades, a cidade, perde o tom praticamente exclusivo. Da dimensão do jovem aristocrata responsável por governar a pólis, ou seja, da cidade como objeto principal, se passa ao eu como objeto. $\mathrm{O}$ eu não mais será tomado de modo apartado da cidade, como se se tratasse de um individualismo; a finalidade do cuidado de si, contudo, passa a ser o eu. Modificação expressiva, pois, de agora em diante, a atividade de cuidado de si, antes voltada para o governo dos outros, quando se tinha esse objeto bem particular e privilegiado que era a cidade, se transforma em "governo de si". Segundo Foucault:

Para esquematizar, acrescentemos ainda que, na análise do Alcibíades, o eue nisso o texto é bem claro, pois era a questão várias vezes repetida: qual o eu com que se deve ocupar-se, qual é meu eu com que devo ocupar-me? - estava muito claramente bem definido como o objeto do cuidado de si, fazendo-se necessário interrogar sobre a natureza desse objeto. Porém, a finalidade do cuidado de si, não o objeto, era outra coisa, era a cidade. Sem dúvida, na medida em que quem governa faz parte da cidade, também ele, de certo modo, é finalidade do próprio cuidado de si e, nos textos do período clássico, encontra-se com frequência a ideia de que o governante deve, como convém, aplicar-se a governar, para salvar a si mesmo e a cidade - a si mesmo enquanto parte da cidade (FOUCAULT, 2006a, p. 103).

A noção de cuidado de si no Alcibíades se apoiava em um esquema complexo, pois a cidade servia como uma mediação da relação do indivíduo consigo mesmo. Posteriormente, com a eclosão da cultura neoclássica e com a eclosão do império o sujeito passaria a ser a finalidade mesma do cuidado de si. Vemos operar uma rotação da prática de cuidado com a cidade para a prática de cuidado consigo mesmo, em que o eu se torna o eixo da prática do cuidado de si, passando para o primeiro plano: para se governar bem a cidade é preciso, em primeiro lugar, governar bem a si mesmo. Importante deixar claro que essa transição não se deu de modo súbito, deparamos com a história da instituição de um modelo de cuidado que opera uma série de investimentos na formação de um eu que se ocupava consigo 
mesmo se constituindo a partir de uma luta contra determinados hábitos e vícios. O cuidado de si, em sua manifestação nos séculos I e II, ultrapassou significativamente a proposta do período clássico, passando a abranger todo um vasto campo de práticas de si, visando à ideia de uma salvação coextensiva à vida, diferenciando-se totalmente da epistrophé ou da metanóia, que garantiam uma salvação extraordinária da vida presente:

Esse é um movimento muito diferente daquele que Platão prescreve quando pede à alma que se volte sobre si mesma a fim de reencontrar sua verdadeira natureza. Plutarco ou Sêneca sugerem, ao contrário, a absorção de uma verdade dada por um ensinamento, uma leitura ou um conselho; e que a assimilemos até fazer dela uma parte de nós mesmos, até fazer dela um princípio interior, permanente e sempre ativo de ação. Em uma prática como essa não encontramos, pelo movimento da reminiscência, uma verdade escondida no fundo de nós mesmos; interiorizamos verdades recebidas por uma apropriação sempre crescente (FOUCAULT, 2006a, p. 607).

Veremos, a partir de agora, como o estilo próprio a esse cuidado, a essa ocupação consigo, chamava a atenção para a instauração de um sujeito ativo na vida presente pela via de uma estética de si, no sentido de priorizar dar uma forma à vida, de acordo com um campo de possibilidades que levava em conta qualquer tipo de acontecimento. Esse posicionamento do sujeito diante da vida combate uma tendência muito comum por parte dos indivíduos, tanto entre nós quanto entre os indivíduos dos séculos I e II - como teremos oportunidade de ver em alguns fragmentos de textos da época, escolhidos no escopo do curso de Foucault -, de paralisar diante das intempéries e dos infortúnios da vida. Como veremos no capítulo referente à metanóia cristã e à epistrophé platônica, essa postura de paralisar diante das dificuldades geralmente se ancora em algum tipo de ideal que se diz capaz de salvar os indivíduos. Esses modelos de salvação antigos (a epistrophé platônica e a metanóia cristã) não constituíam um eu, já que no modelo de conversão a si da metanóia a formulação do eu trata de um eu que deve ser abjurado no momento mesmo em que é levantado. Já a epistrophé recorre a formas universais para delinear sua concepção de eu, uma noção de eu genérica, portanto. 


\subsection{A prática de si do período clássico à época imperial: algumas transformações}

O texto Alcibíades ilustra como o cuidado de si no período clássico fazia parte da exigência pertinente ao momento preciso da vida relacionado à questão do governo da cidade. Foucault acentua que essa ideia de "momento preciso" não se relaciona com o que denominamos por Kairós, concernindo, na verdade, ao que os gregos reconheciam como hora: altura da vida em que se devia ocupar-se consigo mesmo no que diz respeito à pedagogia, à erótica e à política. Tempo no qual o indivíduo, outrora tido como objeto de desejo erótico, começa a tomar para si a responsabilidade, antes atribuída aos pedagogos, de atenção a si mesmo, de ocupação consigo, passando a formar em torno de si um campo de aplicação onde possa exercer sobre si um poder ativo:

Todos sabemos que, certamente em todas as sociedades, o ingresso do adolescente na vida, sua passagem à fase que denominamos "adulta" é problemática e que a maioria das sociedades ritualizou fortemente essa difícil e perigosa passagem da adolescência à idade adulta. O interessante, pareceme, e merecia sem dúvida melhor exame, é que na Grécia, ou pelo menos em Atenas, pois em Esparta deve ter sido diferente, no fundo, sempre se ressentiu e se lastimou por não haver uma instituição de passagem que fosse forte, bem regulamentada e eficaz para os adolescentes no momento de seu ingresso na vida (FOUCAULT, 2006a, p. 107, grifo meu).

Para Foucault, é devido a esse problema de insuficiência da pedagogia, nesse momento confuso entre o fim da adolescência e o início da vida adulta, que podemos situar a formação do discurso filosófico socrático-platônico. Com a Idade de Ouro imperial, o cuidado de si vai se estender desse registro, localizado na fase de transição da adolescência para a vida adulta, a uma exigência para a vida toda, não se atendo a uma época determinada. Observamos então uma transformação no que concerne ao momento da vida em que se deve se aplicar a si. Ou seja, o cuidado de si ganha o contorno de uma forma de vida, no lugar de uma simples preparação transitória voltada para uma exigência social, como, por exemplo, na erótica. Como ilustração dessa nova forma de aplicação a si, Foucault destaca a célebre Carta $a$ Meneceu, de Epicuro:

Quando se é jovem, não se deve deixar de filosofar e, quando se é velho, não se deve deixar de filosofar. Nunca é demasiado cedo nem demasiado tarde 
para ter cuidados com a própria alma. Quem disser que não é ainda ou não é mais tempo de filosofar assemelha-se a quem diz que não é ainda ou não é mais tempo de alcançar a felicidade (FOUCAULT, 2006a, p. 108).

No contexto dessa direção da alma, a ocupação de si na juventude proporcionaria ao indivíduo a compreensão de que, para se atravessar a vida com temperança, é necessário equipar-se com alguns recursos fundamentais. Da mesma forma, a ocupação consigo mesmo na velhice daria chances ao indivíduo de assegurar-se um certo ar de rejuvenescimento, ao se permitir entrar em contato com momentos anteriores da vida a partir de suas memórias. O que vale ressaltar aqui é a ênfase nesse movimento de inflexão subjetiva em que as reflexões sobre a vida têm como ponto de partida as experiências de cada um a partir de sua história. Assim, dentro desse campo da subjetivação, a vida, quando se é jovem, ou quando se é velho, ganha densidade ao ser concebida como um lugar onde se constroem virtudes. Essas virtudes, entendidas nessa prática de si como as transformações dos vícios e maus hábitos que interferem no bom andamento da existência, podem ser traduzidas como recursos para viver da melhor forma possível, independentemente de qual seja o período e, especialmente na velhice, quando recuperadas pela memória, passam a ser tidas como valores, experiências e bagagem de vida. Se nos situarmos por um instante no nosso mundo, vemos que a velhice, além de equiparada à juventude, é percebida por uma ótica da produtividade. Essa perspectiva desvalida todo um acervo de experiências, além de reduzir uma etapa da vida, pela qual a princípio todos os jovens um dia irão chegar, à ideia de improdutividade. Nessa prática do cuidado de si antiga, que estamos analisando, havia uma atenção voltada para cada etapa da existência, conferindo a cada uma delas uma espessura específica e suas respectivas práticas de si.

Uma outra modificação, que decorre inclusive da anterior, está relacionada ao fato de o cuidado de si no período clássico ser aplicado às falhas observadas no contexto pedagógico, se referindo principalmente ao aspecto da formação do ephebo. Com essa ampliação do cuidado de si para a vida como um todo, o aspecto pedagógico acaba se tornando menos relevante, dando lugar a outras funções. Configura-se uma função crítica de desaprendizagem em relação a tudo que se aprendeu, tanto no campo social em um sentido geral, como também equívocos transmitidos por maus mestres e por todos aqueles que fizeram parte da vida do indivíduo, que exerceram influência sobre ele, inclusive a família. Assim, uma das 
primeiras funções da prática de si, que serve, ao mesmo tempo, para abrir o campo do cultivo de si, é a tarefa de "desaprender" (de-discere), isto é, permitir um exercício crítico sobre as certezas construídas ao longo da vida, sobre aquilo que já está arraigado no indivíduo.

Uma terceira transformação diz respeito ao caráter de luta dessa nova forma de cuidado, já que a prática de si obtém também a função de um combate constante. Esse caráter de luta se relaciona ao entendimento de que é necessário empreender uma atividade constante contra o mal-estar inerente à existência. Foucault se refere a duas metáforas para ilustrar a importância conferida a uma certa atividade do sujeito para instaurar um campo de subjetivação no contexto dessa prática de de si:

A da disputa atlética (somos na vida como o lutador que tem de se desfazer de seus sucessivos adversários e que deve se exercitar mesmo quando não combate) e a da guerra (é preciso que a alma esteja disposta como um exército que um inimigo pode sempre atacar) (FOUCAULT, 2006a, p. 602).

É importante ressaltar que o deslocamento do modelo pedagógico no campo da prática de si, e a consequente criação da abertura que deu lugar a novas funções, vai ganhando um enfoque curativo a partir do resgate de elementos do modelo médico. Nesse ponto, Foucault lembra que a noção de páthos, antiga na cultura grega, carrega ao mesmo tempo o significado de paixão da alma e doença do corpo. Diante disso, os campos do corpo e da alma se aproximam e cria-se a possibilidade de aplicação de termos que sirvam tanto a um quanto a outro. Para os epicuristas, cínicos e estoicos, seria atribuição do filósofo curar as doenças da alma, daí expressões como cuidar, amputar, escarificar, purgar. Segundo Foucault:

Plutarco poderá um dia dizer que filosofia e medicina constituem mía khôra, única região, um único domínio. Epicteto não queria que sua escola fosse considerada um simples lugar de formação, mas um "gabinete médico", um iatrềon; queria que ela fosse um "dispensário da alma"; queria que seus alunos chegassem com a consciência de estar doentes: "um, dizia ele, com o ombro deslocado, outro com um abscesso, o terceiro com uma fístula, outro com dores de cabeça" (FOUCAULT, 2006a, p. 603).

Essa forma de direção da alma se estabelece no contexto de uma relação consigo mesmo, sempre ancorada em um vínculo com um mestre, um diretor, um outro, enfim, mas diferencia-se da erótica, que contava com um ingrediente 
amoroso no sentido de uma relação erótica entre o par mestre-ephebo. Nessa nova forma de governo de si, ou seja, de governo da alma, a presença do outro era fundamental no sentido de prestar auxílio ao indivíduo no exercício de domínio de suas paixões. Desse modo, essa prática da alma foi caracterizada por diversos tipos de suportes afetivos. Segundo Foucault:

É um princípio geralmente admitido de que não se pode ocupar-se consigo sem a ajuda de um outro. Sêneca dizia que ninguém é tão forte para se livrar por si mesmo do estado de stultitia no qual se encontra. "É preciso que se lhe estenda a mão e que se o puxe para fora". Galeno, do mesmo modo, dizia que o homem ama demais a si mesmo para ser capaz de sozinho curar-se de suas paixões: ele vira frequentemente "tropeçar" homens que não haviam consentido em se colocar sob a autoridade de um outro. Esse é um princípio verdadeiro para os iniciantes; mas também para o prosseguimento e até o fim da vida. A atitude de Sêneca, em sua correspondência com Lucílio, é característica: mesmo sendo velho, tendo renunciado a todas as suas atividades, dá conselhos a Lucílio, mas também os pede e se felicita pela ajuda que encontra nessa troca de cartas (FOUCAULT, 2006a, p. 603).

A filosofia nesse período é incorporada aos cuidados da alma. O termo grego utilizado é um termo médico - hygiaínein -, pois se tratava de uma série de cuidados que se tinha que ter no decorrer de toda a vida. Essa prática da alma era elaborada em escolas, como a Escola de Epicteto, que acolhia desde visitantes curiosos até alunos que se mantinham vinculados à escola por mais tempo, ou, ainda, aqueles que buscavam a formação específica de filósofo ou diretor de consciência. Também havia a iniciativa de conselheiros privados, principalmente em Roma, estabelecidos em torno de personagens importantes, servindo como guias diante de situações embaraçosas ou como educadores dos mais jovens. O cuidado de si era uma preocupação social de uma certa elite e que efervescia em determinados círculos sociais. Foucault mostra que as escolas filosóficas não inventaram o cuidado de si, tema que aparece nos círculos sociais que figuras importantes da época frequentavam, tais escolas somente incorporaram um ideal social que era bem disseminado, transpondo-o para seu campo de exigências. Importante destacar que o cuidado de si não perde o caráter de atividade mesmo quando passa a ser um princípio filosófico, a partir de sua assimilação pelas escolas filosóficas. O termo epiméleia designa sempre uma atividade, não concernindo meramente a uma atitude de consciência ou uma forma de atenção. 
Alguns exemplos do uso do cuidado de si nesse momento em que passa para as escolas filosóficas pode ilustrar o que foi dito até agora. Sêneca é um desses notáveis que frequentavam os círculos de Roma e que Foucault traz para o seu campo de análise dessas práticas de si. No começo do De tranquillitate, Serenus solicita de Sêneca uma espécie de diagnóstico em relação a seu estado e, ao lhe pedir ajuda, the atribui o papel de médico da alma. No caso, Serenus, para quem também foi dedicado o De constantia e, provavelmente, o De otio, não se aproximava em nada da idade do ephebo Alcibíades. Tratava-se de um jovem, que já passara da adolescência, vindo da província, pertencente a uma família de prestígio, parentes afastados de Sêneca, que chegara à cidade como cortesão e político, tendo exercido influência em uma das relações de Nero com uma de suas amantes - momento em que pede conselhos a Sêneca. Havia toda uma rede de relações entre patrícios, círculo de notáveis de Roma, que girava em torno do cuidado de si, estabelecendo relações pautadas em uma confiança mútua.

Outra referência que Foucault faz a Sêneca, para elucidar essa relação entre patrícios e como eles se apoiavam mutuamente, diz respeito a quando Sêneca, aos 60 anos, retira-se para redigir as Questões naturais. Nesse momento vai se dirigir a Lucílio, que tinha entre 40 e 50 anos, e que exercia o cargo de procurador da Sicília, sendo também um dos exemplos das relações individuais entrelaçadas em torno de Sêneca. Na ocasião da correspondência com Sêneca, Lucílio era procurador da Sicília. E Sêneca não economizou esforços, por meio dessa correspondência, para convencer Lucílio a aderir ao estoicismo, no lugar do epicurismo - que não era tão rigoroso e bem teorizado como o estoicismo. Entretanto, devido à posição política que Sêneca ocupava, que não lhe permitia dedicar muito tempo à pedagogia, ele acaba não sendo uma boa referência para mostrar esse estágio em que a prática de si se espalha por todas as fases da vida, tanto entre os mais jovens quanto entre os mais maduros, alcançando a velhice, pois ele se voltava mais para essas figuras mais influentes, situadas em posições de poder do círculo de notáveis, logo os mais maduros.

Por isso, para Foucault, vale a pena nos atermos por um instante também ao caso de Epicteto, afinal, esse sim era um professor de profissão, que, inclusive, abre uma escola cujo nome é mesmo Escola, onde ele mantém uma conduta rigorosa em relação a seus alunos. Voltando-se principalmente para os jovens, Epicteto censurava aqueles que diziam buscar boa formação filosófica, mas que, na verdade, 
estavam interessados em retornar a suas casas capacitados o suficiente para ocupar postos proeminentes. Aqui percebemos a mesma preocupação que, guardadas as devidas proporções, Sócrates teve com Alcibíades, ou seja, uma certa onipotência que faz parte da juventude, geralmente presente em qualquer época histórica. Epicteto criticava aqueles alunos que, tendo chegado à escola dispostos a aprender com os ensinamentos, ao perceberem que as instruções recebidas não se voltavam para garantir brilhantismo nenhum, e sim lhes requeriam um rigoroso trabalho moral, abandonavam a escola. Além de todo esse rigor no sentido próprio da formação, Epicteto se preocupava com o modo de os alunos se conduzirem quando fossem às compras, se ocupando em lhes dar conselhos. Esse quadro parece indicar que os jovens que buscavam sua escola eram frágeis, submetidos a um controle bem rígido e direcionado. Tudo isso está registrado nos Diálogos compilados por Arrianus. Vamos às observações de Foucault. Em suas palavras:

É inteiramente verdade que Epicteto se dirigia a esses jovens. Não se deve pensar que todo o cuidado de si, como eixo principal da arte da vida, fosse reservado somente aos adultos. Paralelamente, porém, entrelaçada com essa formação de jovens, pode-se dizer que existia, em Epicteto e na sua escola, o que poderíamos chamar, usando uma metáfora sem dúvida pouco adequada, uma prestação de serviços, serviços prestados a adultos. Com efeito, por um dia, alguns dias ou algum tempo, adultos iam à escola de Epicteto escutar seus ensinamentos. [...] Epicteto não desconsidera essa clientela ou esses interlocutores adultos, pois a seus próprios alunos, jovens portanto, aconselha irem encontrar os personagens notáveis de suas cidades e sacudi-los um pouco interpelando-os: dizei, pois, de que modo viveis? Ocupai-vos verdadeiramente com vós mesmos? (FOUCAULT, 2006a, p. 111).

Outro exemplo que indica que o cuidado de si consistiu não somente em um princípio, mas sim em uma prática constante voltada para todas as fases da vida, torna-se visível na atividade oratória dos cínicos, que também abrangia um público de idades variadas, afinal, ela se dava em esquinas, praças públicas e festas que envolviam datas oficiais. Os exemplos dos textos de Díon de Prusa ilustram bem essa ideia de discursos voltados para temas tais como "ascese, do retiro em si mesmo, da anakhóresis eis heautón etc." (FOUCAULT, 2006a, p. 112).

A direção de alma vai ganhar então as mais variadas formas, desde as relações familiares até relações de proteção, passando pelas relações de amizade entre duas pessoas muito próximas por fatores como cultura, status ou idade, por exemplo. Observe-se que o éros tradicional não é o centro das relações, como foi no período 
clássico, o que não quer dizer que as relações não fossem intensas. Interessa-nos indicar aqui o que Foucault ressalta no tocante a essa intensidade: que nossas categorias modernas de amizade e de amor não são capazes de alcançá-la.

Assim, do Alcibíades até o desenvolvimento de uma autêntica cultura de si bem delineada no início da era imperial, é importante destacar a assimilação entre filosofar e ter cuidado com a própria alma. A atividade filosófica dá enfoque à felicidade, ganhando assim maior importância no sentido de se tornar uma atividade voltada para a vida como um todo, tanto na juventude quanto na velhice.

\subsection{A paraskheué: o suporte emocional para a vida}

Nos dois polos da existência, a juventude e a velhice, o cuidado de si foi definido de modo diferente. Isso porque, como acabamos de ver, na juventude o fim desse cuidado era a preparação - paraskheué, incumbência de armar-se, equipar-se para a vida -, enquanto na velhice o cuidado de si entra sobretudo como um exercício de incremento desse momento da existência, a partir do exercício de se desligar durante alguns momentos da inevitável aproximação do fim da vida pelo gesto ativo de rememoração dos acontecimentos vividos e do resgate de lembranças e experiências afetivas em uma troca entre os pares - exercício de se manter vivo e ativo mesmo diante das inevitáveis limitações do corpo . Tanto os epicuristas quanto os estoicos davam devida importância à prática de si entre esses marcos da existência - juventude e velhice.

Como vimos até agora, além da expansão do período caracterizado pela prática de si, verificamos uma mudança significativa em sua abrangência social, já que transita de um tipo de relação dual mestre-discípulo para um campo de relações sociais múltiplas. Podemos concluir então que há um movimento da subjetivação, uma inflexão da subjetivação diante do problema que se colocava em relação ao governo do outro. Aqui o político muda de figura, só se torna possível governar o outro se for possível governar a si próprio, somente com o conhecimento de si mesmo seria possível se situar e conduzir o outro. No novo modelo a mestria não desaparece, mas se mescla a uma gama de outras relações. A educação ateniense tem um problema, pois o modelo mestre-discípulo circunscrevia uma forma de cuidado em que se cuidava do ephebo, mas não se lhe ensinava a cuidar de si mesmo. Além disso, o mestre que transmitia o cuidado de si não se ocupava com o seu próprio cuidado. Porém, se havia essa crítica a Atenas, tal crítica portava ao 
mesmo tempo um quê de elogio. Isso porque lá havia um espaço para o cuidado de si, um ter de se situar em relação a si mesmo, um governo de si, enquanto nos outros lugares havia somente uma função a cumprir, uma espécie de adestramento.

Isso pode ser ententido como a consideração da ética como uma morada de si mesmo, a partir do estabelecimento de um cuidado principal e imperativo em relação às próprias atitudes, buscando a criação de valores, em um movimento que cultiva virtudes, mediante o entendimento de que há uma verdade que não se possui, mas que pode ser obtida a partir de um esforço na relação consigo mesmo. Essa virtude tem um quê de eternidade, ${ }^{17}$ uma vez que se trata de uma experiência pessoal que não pode ser anulada, ficando inscrita no campo da subjetivação de cada um - no qual se governa a si mesmo, se domina a si mesmo, antes de se ser dominado pelo outro. A virtude aqui corresponde ao elemento ético da verdade, concernindo a um impulso de autotransformação pelo qual o sujeito traça por si mesmo uma direção para sua vida.

A prática de si foi um imperativo que entabulou uma vinculação bastante significativa com os filósofos, com a filosofia e suas instituições. Eles formulavam os textos que circulavam, que eram publicados como manuais de prática de si, produzindo toda uma agitação em torno do assunto. No entanto, essa figura do filósofo, já controversa desde Sócrates, sempre desencadeou reações negativas também. Figura problemática, criticada pelos retóricos, que, com o desenvolvimento do que ficou conhecido como segunda sofística, no século II da nossa era, vai se tornando objeto de desconfiança, uma vez que esse personagem do filósofo emitia opiniões políticas a favor de um ou outro, exercendo significativa influência e, sobretudo, exercia sua atividade como profissional que insistia em incitar as pessoas a que cuidassem de si mesmas, suscitando a instalação de determinados problemas políticos e polêmicas relevantes. ${ }^{18}$ Observemos enfim que

\footnotetext{
${ }^{17}$ A virtude é uma construção do sujeito a partir de sua história, de sua singularidade. Ela é eterna e, da mesma forma que uma experiência traumática não se apaga de todo, ela pode ser até elaborada e ressignificada, mas não anulada por completo.

${ }^{18}$ A segunda sofística deve sua existência cultural às Vidas dos sofistas, de Filostrato de Lemnos (começo do século III). Os sofistas, a partir dos grandes retratos de Platão, são sempre aqueles oradores e professores que circulam de cidade em cidade distribuindo lições de sabedoria. A comparação, porém, limita-se a isso, pois os "segundos" sofistas se dispersam (no lugar de concentrar-se em Atenas) e exibem-se nos teatros e outros auditórios (não tanto nas residências particulares dos ricos). Ademais, "a segunda sofística, mais do que qualquer outro gênero, encarna o compromisso histórico entre a cultura grega e o poder romano", porquanto vemos por vezes o sofista que "tenta, nas cidades, apaziguar os conflitos que pudessem surgir com o governador local e pregar uma concórdia ajustada às expectativas dos romanos” (Foucault, 1997, p. 203).
} 
o complexo relativamente à filosofia parece invertido em relação ao período ateniense: nas suas Dissertações, Élio Aristide reprova firmemente a condenação da retórica (Górgias) por Platão e coloca acima de tudo a aprendizagem formal do retórico. A superioridade da retórica é assumida, reivindicada, e a filosofia é que passa a ser então considerada como um jogo inútil e incerto. ${ }^{19}$ Segundo Foucault:

Para Epicuro, como vemos, deve-se filosofar todo o tempo, deve-se incessantemente ocupar-se consigo. Se tomarmos agora os textos estoicos, encontraremos a mesma coisa. Dentre centenas, citarei apenas o de Musonius Rufus, segundo o qual é cuidando-se sem parar (aeì therapeúontes) que se pode salvar-se. Ocupar-se consigo, portanto, é ocupação de toda uma vida, de toda a vida. De fato, se observarmos no período de que lhes falo a maneira como se praticou o cuidado de si, perceberemos que é realmente uma atividade de toda a vida (FOUCAULT, 2006a, p. 109).

Assim, essa prática passa a fazer parte principalmente do contexto adulto, mais do final da idade adulta, se distanciando significativamente, como vimos, do modelo antigo, que se situava na adolescência. Observa-se uma mudança da paisagem dos jovens de Atenas dos séculos V e IV, ávidos pelo poder, para a constituição de um mundo onde jovens maduros incitam a si mesmos e uns aos outros para a prática de si.

A recentralização do cuidado de si na idade adulta indica, sem sombra de dúvida, um refinamento de sua função crítica, pois então sua função é mais voltada para a reparação e o aprimoramento de si do que para a formação, ganhando peso no que se refere a uma crítica de si mesmo. Não que o seu papel formador tenha se extinguido, mas a ênfase vai ser dada à prática da crítica. Vale ressaltar aqui que nos diálogos socráticos, incluindo o Alcibíades, todo esse plano do cuidado de si girava em torno do elemento da ignorância própria aos indivíduos. Alcibíades, por exemplo, ignorava o que se propunha a fazer, ou seja, de que maneira poderia governar bem a cidade, e ainda ignora que ignora.

A prática de si pertinente ao período helenístico e romano tem um lado formador, ligado à formação do indivíduo no sentido de seu preparo, que não se reduz ao aspecto profissional ou de atividade social. Longe do modelo do

\footnotetext{
${ }^{19}$ Sobre essa segunda sofística, cf.: de G. Bowersock, Greek sophists in the Roman Empire (Clarendon Press, 1969); de G. Anderson, The second sophistic: a cultural phenomenon in the Roman Empire (Routledge, 1993); e de B. Cassin, L'Effet sophistique (Gallimard, 1995) (cf. neste último o vínculo entre a segunda sofística e o nascimento do romance grego).
} 
Alcibíades, voltado para a formação do indivíduo como um bom governante, esse outro modelo tinha como objetivo preparar o indivíduo para que ele viesse a suportar da melhor forma possível todas as dificuldades da vida. Não se tratava de um saber técnico. Independentemente desse tipo de saber, o peso aqui era dado à paraskheué, ou seja, ao desenvolvimento de um suporte de segurança focado no lado emocional de cada um. O suporte emocional era um investimento que se fazia em si mesmo, que valorizava a forma de lidar com os abalos sentimentais advindos dos reveses inevitáveis do decorrer da vida. Sêneca traduz a paraskheué por instructio, que dizia dessa armadura individual usada para lutar contra os infortúnios e os golpes da vida. Segundo Foucault:

Esse aspecto formador, contudo, de modo algum é dissociável de um aspecto corretivo que, a meu ver, torna-se cada vez mais importante. A prática de si não mais se impõe apenas sobre o fundo de ignorância, como no caso de Alcibíades, ignorância que ignora a si mesma. A prática de si impõe-se sobre o fundo de erros, maus hábitos, de deformação e de dependência estabelecidas e incrustadas, e que se trata de abalar. Correção-liberação, bem mais que formação-saber: é nesse eixo que se desenvolverá a prática de si, o que, evidentemente, é fundamental. [...] Tornamo-nos o que nunca fomos, esse é, penso eu, um dos mais fundamentais elementos ou temas dessa prática de si (FOUCAULT, 2006a, p. 116).

Sêneca compara os corpos físicos aos não físicos, afirmando que, se é possível "endireitar vigas grossas quando encurvadas", por que não endireitar o espírito humano se ele é flexível? Em sua concepção, se obtém uma bona mens (alma de qualidade) após seu estado de mala mens, ou seja, o estado de perfeição só pode ser obtido se o de imperfeição for trabalhado e aperfeiçoado, não vindo de graça. Da ideia de que somos sempre praeoccupati, descrita na carta 50, ou seja, prontamente ocupados com alguma coisa quando visamos fazer o bem, Sêneca elabora uma fórmula que teve lugar no vocabulário cínico e que modula a noção de desaprendizagem, noção capital nos cínicos e que será reencontrada nos estoicos "virtutes discere é vitia dediscere", que significa que aprender as virtudes é desaprender os vícios.

A ideia de se paramentar está totalmente ligada à de desaprendizagem, que deve ter lugar desde o início da prática de si, na juventude. Essa reformação crítica de si, que tem a natureza como fundamento - uma natureza, todavia, de modo algum dada, nunca revelada como tal no indivíduo humano -, volta-se para uma ideia de 
podar, desbastar toda a formação previamente recebida e tudo que o meio proporcionou, a contar desde a primeira infância. Foucault esclarece que:

Nisso consiste a famosa crítica, tantas vezes repetida, da primeira educação e dessas famigeradas histórias da carochinha com as quais, desde cedo, se oblitera e deforma o espírito da criança. Lê-se em um conhecido texto de Cícero, nas Tusculanas: "Desde que nascemos e somos admitidos em nossas famílias, encontramo-nos em um meio inteiramente falseado onde a perversão dos julgamentos é completa, tanto que, pode-se dizer, sugamos o erro com o leite de nossas amas". Crítica, pois, da primeira infância e das condições em que ela se desenrola. Crítica também do meio familiar, não somente em seus efeitos educativos, como ainda, se quisermos, [pelo] conjunto de valores que ele transmite e impõe; crítica do que, em nosso vocabulário, chamaríamos de "ideologia familiar" (FOUCAULT, 2006a, p. 117).

Observe-se que a formação do sujeito tem sua base na esfera familiar, que, por sua vez, encontra-se fortemente voltada aos interesses pertinentes ao conjunto social. A ligação entre essas esferas sociais responde a uma série de demandas provenientes do campo político. Cícero atenta para essas relações em sua época e é evidente, para nós, o quanto esse ponto é atual. Devido a uma gama de interesses do campo social, deforma-se a criança, ao invés de formá-la a partir de uma ética refletida. O caráter infantil da criança é utilizado como desculpa para que os adultos manipulem a infância, movidos pelos interesses complexos e obscuros provenientes dos poderes estabelecidos.

O poder se instala no conjunto social, produzindo discursos em cima de práticas concretas de existência, se utilizando das forças em jogo no seu cerne. Por isso faz parte do cuidado de si desaprender aquilo que se tem como certo, como verdades arraigadas em nós. Os cínicos, epicuristas e estoicos estavam atentos a esse problema, já ligavam educação, instituição e poder naquele contexto. Diante disso, puderam refletir que, no lugar dessa primeira educação "deformadora" que manipulava os indivíduos, se devia abrir um campo de elaboração de uma prática de formação que partisse de uma relação consigo, mas que levasse em conta uma interlocução com o outro capaz de ajudar a voltar os olhos para aquilo que se queria negar, evitar, que, se encarado de frente, poderia servir como recurso para a construção de virtudes. A presença do outro no cuidado de si, como vimos no tópico anterior, é fundamental. 
Esse equipamento para atravessar a existência a partir da formação de virtudes era forjado pelos discursos racionais e verdadeiros - os lógoi. Era essa a chave de que se podia lançar mão para lidar com os acontecimentos. Lucrécio fala de veridica dicta como o que torna possível que se vença aquilo que se acredita ser um fracasso, uma perda ou infortúnio. ${ }^{20}$

No que concerne às escolas filosóficas, formavam-se várias opiniões. Em relação à questão da natureza, por exemplo, uns defendiam a necessidade de se ter conhecimentos teóricos a respeito dos princípios que regem o mundo, a natureza, as leis da vida e da morte, para se preparar para os acontecimentos. Já os estoicos, mostra Foucault, se dividiam segundo sua proximidade no que diz respeito às doutrinas cínicas: uns atribuíam importância maior aos dógmata, aos princípios teóricos que se juntavam às prescrições práticas para atingir suas metas; enquanto, para outros, as regras de conduta prescindiam de premissas teóricas. Segundo Foucault:

\begin{abstract}
Convém assinalar aqui que esses discursos verdadeiros de que precisamos só concernem àquilo que somos em nossa relação com o mundo, em nosso lugar na ordem da natureza, em nossa dependência ou independência quanto aos acontecimentos que se produzem. Não são, de forma alguma, uma decifração de nossos pensamentos, de nossas representações, de nossos desejos (FOUCAULT, 2006a, p. 606).
\end{abstract}

Outra questão referente aos discursos verdadeiros tem a ver com o modo como esses discursos povoam a esfera subjetiva dos indivíduos. Porque é certo que eles deveriam estar à mão no caso de um infortúnio. Foucault afirma que a expressão vigente na época para os gregos era prókheiron ékhein, traduzida pelos latinos por habere in manu, in promptu habere - ter à mão. Não se trata de ter esses discursos em mente no nível de uma lembrança. Nos textos de Plutarco, encontramos uma série de metáforas utilizadas para marcar a presença desses discursos na vida dos indivíduos. Segundo Foucault, esse autor:

\footnotetext{
${ }^{20}$ Nessa cultura de si, o peso sobre os infortúnios era atribuído principalmente ao investimento emocional dado pelos indivíduos às pessoas e coisas. Assim, longe de negar a dor, conferia-se um enfoque racional aos acontecimentos, no sentido de entrar em contato com as emoções a partir de um certo nível de conformação. Isso não quer dizer se resignar diante de uma situação de sofrimento, mas de saber que, diante de um infortúnio, é necessário atravessá-lo, sempre em uma atividade do sujeito consigo mesmo, em relação às suas emoções.
} 
Compara-os a um medicamento (phármakon), de que devemos estar munidos para prevenir todas as vicissitudes da existência (Marco Aurélio compara-os ao estojo que um cirurgião deve ter sempre à mão); Plutarco fala deles também como de amigos dentre os quais os "mais seguros e melhores são aqueles cuja presença útil na adversidade nos traz socorro"; em outra parte, evoca-os como uma voz interior que se faz ouvir por si mesma quando as paixões começam a agitar-se; é preciso que estejam em nós como "um mestre cuja voz basta para apaziguar o rosnar dos cães" (FOUCAULT, 2006a, p. 606).

Ao estar com esses discursos sempre à mão, o sujeito se colocava ao mesmo tempo em contato com os seus maiores desafios pessoais, visto que aquilo que, para ele, servia como discurso verdadeiro na ocupação consigo próprio tocava os seus maiores medos e dificuldades.

\subsection{A prática de si como uma prática social de conjunto}

As práticas de si dos estoicos e cínicos traziam à baila o tema político, sendo exercidas em uma relação de amizade mestre-discípulo distinta da relação do éros de Sócrates e de seus discípulos, ou do éros referente à amizade epicurista. Eufrates, um dos principais filósofos estoicos, não separava prática filosófica de vida política. Foucault analisa uma célebre passagem, dedicada a Eufrates, da décima carta do primeiro livro das Cartas, de Plínio. Foucault recorta o seguinte trecho da carta de Plínio:

Eufrates vivia na Síria; Plínio o conheceu quando "adulescentulus militarem", isto é, quando, muito jovem, estava prestes não exatamente a fazer seu serviço militar, mas a ocupar um posto militar. É jovem, portanto, mas não uma criança ou adolescente em idade escolar. Esse texto nos mostra que Plínio o frequentou e intimamente. "Penitus et domi inspexi": eu o vi, pude olhá-lo, examiná-lo penitus (a fundo) et domi (em casa). Isso significa que partilhou de sua existência ou, pelo menos, teve com ele uma frequentação contínua a fim de partilhar com ele certos momentos da vida, fases da existência. Em terceiro lugar, fica claro que há entre os dois uma relação afetiva intensa, porquanto é dito que "amari ab eo laboravi, etsi non erat laborandum", o que significa: trabalhei para ser por ele amado, embora ele não tenha tido que trabalhar para isso (FOUCAULT, 2006a, p. 188).

Foucault ressalta que em nenhum momento Plínio alude ao fato de que amava Eufrates, isso fica subententido no texto e no elogio a Eufrates. Para Foucault, o que interessa ressaltar é que, na noção de amizade própria aos romanos, nesse 
contexto do cuidado de si, se observa uma dimensão laborativa em torno de deveres, técnicas, obrigações e condutas cuidadosamente elaboradas:

No De beneficiis, de Sêneca, afirma-se que, em uma amizade, além de prestar serviços, existe ainda todo um trabalho, todo um labor pelo qual nos fazemos amar por aquele cuja amizade desejamos. Esse trabalho, por sua vez, desdobra-se com certas fases e aplicação de algumas regras, que são sancionadas pela relativa posição de uns para com outros no círculo de amizades daquele cuja amizade é desejada. Em outras palavras, a amizade não é exatamente uma relação de um com outro, não é a comunicação imediata entre dois indivíduos, como na fórmula epicurista (FOUCAULT, 2006a, p. 188).

Ou seja, nesse contexto, deparamos com uma estrutura social da amizade na qual um indivíduo tem destaque, todavia há um grupo em torno dele com um lugar específico, lugar mutável de acordo com a elaboração, com o labor exercido por cada um dos elementos do grupo que gira em torno desse indivíduo determinado. As características desse labor estavam relacionadas à dedicação às lições, ao empenho pela aprendizagem, à aceitação das direções dadas por Eufrates.

É quase certo que nesse exemplo, como se vê no modelo de amizade romana, houvesse troca de serviços entre eles. O que interessa ressaltar aqui é o fato de Plínio ter investido na amizade a partir de parâmetros que não se aproximam do modelo do éros grego. Esse modelo de amizade nos faz acompanhar alguns elementos importantes do cuidado de si em relação ao campo social. Para isso, é importante nos atermos à descrição que Foucault resgata do texto sobre Eufrates, que era um importante filósofo estoico. Ele diz que sua aparência é bem familiar ao personagem do filósofo: tem barba e boa apresentação, ou seja, vestia-se bem, falava de maneira requintada, agradável e persuasiva; que era bastante acolhedor, agradável aos ouvidos, e que praticava as virtudes que transmitia, tal como Platão. Diante daqueles que cometem falta, ele não só não os repreende como não os maltrata, agindo com indulgência e com liberalitas. Em seus ensinamentos, sempre marcava que a relação entre a justiça, a administração das coisas da cidade e o ofício de representante local, ou de representante da autoridade romana e imperial, eram os elementos que caracterizavam o trabalho do filósofo.

Foucault chama a atenção para o fato de que, ao compararmos a descrição de Plínio com o quadro descrito anteriormente, entramos em contato com uma descrição completamente diferente. Plínio o cita como um personagem 
excepcional, cheio de qualidades, com quem se é capaz de se relacionar de maneira intensa. Não há comentários relativos a dinheiro em toda essa situação. Todos os traços de caráter considerados por Plínio a respeito de Eufrates excluem os elementos caraterísticos dos filósofos de profissão, já que, tradicionalmente, eles circulavam em vestes desajeitadas e tinham uma linguagem rude. Eufrates se apresentava com roupas limpas e se fazia ouvir de modo agradável. Para Foucault:

Ao explicar quanto Eufrates fala bem, quão requintada é a sua linguagem, como convence tão bem que depois de se estar convencido se desejaria continuar a ouvi-lo, apesar de não se precisar mais ser convencido, o que faz Plínio senão mostrar que Eufrates não é um filósofo de linguagem rude, áspera, limitada ao seu único objetivo - convencer e mudar a alma de seu ouvinte -, mas que ele é também um pouco retórico, que ele soube integrar [...] os prazeres próprios [...] ao discurso retórico no interior da prática filosófica? É a diluição daquela famosa separação entre retórico e filósofo que fora um dos mais característicos traços da profissionalização do filósofo (FOUCAULT, 2006a, p. 190).

Ele se diferencia de Epicteto e dos cínicos pela maneira como trata as pessoas, já que as acolhe generosamente, em vez de se mostrar ríspido, comportamento que tinha como função impelir os outros a se transformarem e a adotarem outro modo de existência. $\mathrm{O}$ fato de conceber que fazer justiça e administrar a cidade definiam a prática filosófica apaga na vida filosófica o seu traço particular de parecer retraída em relação à vida política. Para Eufrates, vida filosófica e vida política se confundem. O que mostra que toda essa valorização que Plínio tece a esse filósofo não se resume apenas a uma homenagem de um jovem a um antigo mestre, nos moldes de um jovem nobre romano a um importante filósofo do Oriente Médio.

Foucault analisa esse discurso com detalhes, pois, para ele, aí encontramos elementos que apresentam todo um reconhecimento pela repatriação da filosofia em um modo de existência, na maneira de se conduzir, em um conjunto de valores, em um conjunto de técnicas que não são da filosofia tradicional:

Todo um conjunto de cultura, em que figuram os velhos valores da liberalidade romana, as práticas da retórica, as responsabilidades políticas etc. No fundo, Plínio promove o elogio de Eufrates unicamente na medida em que o desprofissionaliza em relação ao retrato tradicional do filósofo que faz somente filosofia. Ele o mostra como uma espécie de magnânimo senhor da sabedoria socializada (FOUCAULT, 2006a, p. 191). 
Esse registro pode ser considerado uma prova, junto com outras que vamos encontrar em nossa busca pelas pistas, de que essa prática de si se transformou em uma prática social de conjunto, para além das instituições, dos grupos, daqueles que, em nome da filosofia, se incumbiam do magistério, da prática de si. A prática de si foi se desenvolvendo fora da instituição filosófica, fora da profissão de filósofo, e se transformando em um tipo específico de relação entre os indivíduos. E, nessa relação, foi se estabelecendo um tipo de controle entre os indivíduos, de formação e desenvolvimento, uma relação do indivíduo consigo mesmo, em que o ponto de apoio é encontrado no outro, que não precisa ser um filósofo de profissão, apesar de ser necessário que esse indivíduo tenha passado por algum tipo de experiência com a filosofia, tendo entrado em contato com as noções da filosofia. Segundo Foucault:

Em outras palavras, creio que é o problema da figura, da função do mestre que está aí em questão. No tempo dos sofistas, no tempo de Sócrates, no tempo de Platão ainda, um mestre era [considerado] na sua singularidade, quer com base em sua competência e habilidade sofísticas, quer em sua vocação de thê̂os anér (homem divino e inspirado), como em Sócrates, quer no fato de que já teria alcançado a sabedoria, como no caso de Platão. Pois bem, esse mestre está em vias não exatamente de desaparecer, mas de ser invadido, cercado, ameaçado por toda uma prática de si que é, ao mesmo tempo, uma prática social. A prática de si vem vincular-se à prática social ou, se quisermos, a constituição de uma relação de si consigo mesmo vem manifestamente atrelar-se às relações de si com o Outro (FOUCAULT, 2006a, p. 192).

Ao referir-se ao desenvolvimento da carreira de Sêneca, Foucault trata da expressão "filósofo profissional" em um sentido mais abrangente daquele entendido na época, já que os interlocutores de Sêneca não são necessariamente discípulos, como se observava na relação mestre-discípulo circunscrita ao âmbito da filosofia profissional. Sêneca começa sua carreira no exílio, escrevendo intervenções diferenciadas para seus interlocutores, de acordo com o lugar que ocupavam na sua vida. Assim, exerceu o papel de mestre, de diretor de consciência, até mesmo para pessoas com quem tinha relações próximas. Por exemplo, escreveu uma consolação para sua mãe quando foi para o exílio, assim como tratados de filosofia, conselhos, entre outros textos. Desse modo, reconhecido como filósofo a partir dessa atividade no exílio, é convocado a ser conselheiro de Nero. Nada comparado ao papel de Epicteto ou de Eufrates, professores de filosofia; sendo que 
este último tinha, como visto anteriormente, aspectos específicos que o diferenciavam. Sua atividade foi marcada por um traço político, administrativo. É nesses termos de semiparentesco/semiclientelismo que Sêneca, diz Foucault, mantém relações com Serenus, acolhendo suas demandas e formulando seus conselhos. Já com Lucílio, o tom é um pouco mais de diretor de consciência, talvez por ele ser mais jovem, antigo protegido, mas ocupando altas funções administrativas. Com Plutarco temos uma atitude similar, pois sempre se dirige a ele articulando uma relação social ou de status, uma relação política, podemos dizer assim:

É a essas relações que ele atrela, enxerta a atividade que consiste em dirigir a consciência. Portanto, não é, por assim dizer, enquanto filósofo profissional que Sêneca e Plutarco intervêm para guiar os outros. É na medida em que as relações sociais que eles mantêm com uma ou outra pessoa (amizade, clientelismo, proteção etc.) implicam, a título de dimensão - e, ao mesmo tempo, a título de dever, de obrigação -, o serviço da alma e a possibilidade de fundamento de uma série de intervenções, de conselhos que permitirão ao outro conduzir-se como convém (FOUCAULT, 2006a, p. 193).

Do lado daquele que é dirigido, temos o testemunho, por exemplo, de Marco Aurélio, que se correspondeu com seu mestre Frontão. Essa correspondência, aliás, quase não foi publicada, por se tratar de um tipo estranho de comunicação, o que dificulta que seja acessada na França. Foucault esclarece que Frontão era um retórico, um mestre de retórica no caso, e não de filosofia.

Em um dos relatos referentes a Frontão, Marco Aurélio diz que, graças a ele, teve a oportunidade de ver como o poder contém em si uma enorme cota de hipocrisia, além de ter concluído também que os aristocratas não têm capacidade de troca afetiva.

Essas observações indicam que Frontão se caracterizava pela franqueza, se opondo à hipocrisia e à lisonja. Esse exemplo indica também a afeição como suporte emocional que legitima esse tipo de relação. A carta de Marco Aurélio a Frontão (carta IV das Cartas de Marco Aurélio) ilustra com clareza o que era a direção de consciência por parte do dirigido:

Estamos passando bem. Dormi pouco por causa de uma pequena agitação que, entretanto, parece ter-se acalmado. Assim, das onze horas da noite até as três da manhã, passei parte do tempo lendo a Agricultura de Catão e parte 
também escrevendo; menos que ontem, felizmente. Depois, cumprimentei meu pai, engoli água adocicada até a goela e lancei fora em seguida, de modo que mais adocei a garganta do que realmente gargarejei; pois sob a autoridade de Novius e outros, posso empregar a palavra "gargarejei". Tendo restaurado a garganta, dirigi-me para junto do meu pai. Assisti à sua oferenda e depois fomos comer. Com o que pensas que fiz meu desjejum? Com um pouco de pão, enquanto via os outros devorando ostras, cebolas e sardinhas bem gordas. Depois, fomos colher uvas; suamos bastante, gritamos bastante. Na sexta hora retornamos à casa. Estudei um pouco, sem proveito. Em seguida, conversei muito com minha mãe, que estava sentada sobre a cama. [...]. Enquanto conversávamos assim e disputávamos qual dos dois amava melhor o seu [isto é, se Marco Aurélio amava Frontão melhor que sua mãe amava Gratia, filha de Frontão, creio eu], o gongo soou e anunciou-se que meu pai se pusera ao banho. Assim, tomamos a refeição depois de nos termos banhado no lagar. Não quero dizer que nos banhamos dentro do lagar, mas que depois de termos nos banhado tomamos a refeição no lagar e ouvimos prazerosamente os divertidos assuntos dos aldeões. De volta para casa, antes de me virar de lado para dormir, descarrego o meu fardo (meum pensum expliquo) e presto contas do meu dia a meu dulcíssimo mestre (diei rationem meo suavissimo magistro reddo). Mestre este que, a preço até mesmo de minha saúde, de meu bem-estar físico, eu gostaria de desejar, sentir a falta, mais do que já faço. Estejas bem, caro Frontão, tu que és meus amor mea voluptas (meu amor, meu deleite). Eu te amo (FOUCAULT, 2006a, pp. 195$6)$.

Essa longa citação ganha lugar aqui para indicar alguns pontos importantes no que diz respeito, por exemplo, ao fato de que Frontão não é mestre de filosofia, e sim um retórico, um philólogos, como bem mostra o relevo dado à palavra "gargarejado". Aí o destaque é dado para a relação de amizade, e não uma relação profissional nos moldes da direção de consciência. Isso aparece muito claramente no relato terno e afetuoso. Para Foucault, seria errôneo dar ênfase ao aspecto sexual da relação, pois se trata na verdade de uma relação afetiva intensa e ampla. Foucault confere valor ao aspecto afetivo da relação entre ambos, à intensidade que se apresenta, pela necessidade de Marco Aurélio de contar para Frontão tudo o que se passava com ele, toda essa meticulosidade da carta, que trata do relato de um dia inteiro, desde seu despertar até seu último instante. Para Foucault, devemos prestar atenção ao fato de essa carta consistir em um relato de si através do relato do dia. Diante disso, Foucault desenha três categorias relevantes nessa carta: os detalhes sobre o regime, sobre a saúde; a prestação de contas dos deveres familiares e religiosos; e os elementos concernentes ao amor. Ele tece descrições sobre pequenas agitações e medicações, anotações também encontradas frequentemente nos registros de Sêneca, o que quer dizer que esse tipo de registro era 
tradicionalmente feito. $\mathrm{O}$ mesmo pode ser dito sobre o sono, quando, por exemplo, fala sobre "dormir de lado", preceito médico-ético bem comum da época - dormir de lado evitava o que se dava ao se dormir de costas: as visões eróticas; a alimentação, quando compara a escolha de sua refeição a dos outros; e as descrições sobre o banho e exercícios. Todos esses elementos, desde Hipócrates, fazem parte do regime médico.

No que diz respeito aos deveres familiares, religiosos e agrícolas, Marco Aurélio descreve nesse trecho uma vida de agricultor - ao que Foucault esclarece que esse modelo de vida de agricultor anda junto com outros modelos. É o que indica a menção à obra De agricultura, de Catão, que descreve os comportamentos convenientes a quem almejasse ser um proprietário agrícola em Roma, próspero, ético e que contribuísse com a cidade. $\mathrm{O}$ modelo que lhe serve de base, para Foucault, é, sem sombra de dúvida, a Economica, de Xenofonte, sobre o modelo de vida de um senhor da Ática para os séculos V e IV.

Foucault ressalta que esses modelos são bem importantes. Fica claro que é um modelo ao qual se atribuía valor, por exemplo, pelo fato de Marco Aurélio, que era filho adotivo de Antonino e que estava destinado ao Império, não ter necessidade alguma, em termos concretos de existência, de ter que levar a vida como um camponês. Isso certifica que se trata de um modelo. De acordo com Foucault:

Isto fica bem claro desde o final da República e mais ainda desde o Império - a vida agrícola, uma espécie de estágio na vida agrícola constituía não exatamente um descanso, mas um momento de se posicionar na existência a fim de ter precisamente uma espécie de referência na vida de todos os dias, referência político-ética. Com efeito, nessa vida camponesa, se está mais próximo das necessidades elementares e fundamentais da existência; mais próximo também daquela vida arcaica, antiga, dos séculos passados, que nos deve servir de modelo. Nessa vida, tem-se ainda a possibilidade de praticar uma espécie de otium cultivado. Isso significa [igualmente] que são feitos exercícios físicos: vemos que ele pratica a vindima; a vindima, aliás, lhe permite suar e gritar bastante, exercícios que fazem parte do regime. Ele leva, pois, essa vida de otium, que tem elementos físicos e que lhe deixa tempo suficiente para ler e escrever. Portanto, o estágio camponês é uma espécie de reativação do velho modelo de Xenofonte ou do velho modelo de Catão: modelo social, ético e político, agora retomado, mas a título de exercício (FOUCAULT, 2006a, pp. 198-9, grifo meu). 
Trata-se de uma prática de si espelhada no modelo de retiro, para se trabalhar sobre si mesmo, com vista a atingir a si mesmo, mas, ao mesmo tempo, feita com os outros também. Essa prática tem tudo a ver com a proposta de vida econômica de Xenofonte, que achava fundamental uma reflexão voltada para determinadas regras de conduta em relação às relações familiares, à atividade de dono da casa, incumbido das tarefas da casa, dos serviçais, de seus parentes, de seus bens e de si mesmo. Resgata-se esse mesmo panorama, mas agora a finalidade passa a ser o sujeito, tudo isso se volta para fins de exercício pessoal.

A questão do amor é, sem sombra de dúvida, o terceiro aspecto aludido na carta. Há um deslocamento da questão sobre o verdadeiro amor, típica entre os filósofos gregos clássicos, que formulavam indagações em torno de quatro elementos: o amor pelos rapazes ou pelas mulheres e o amor que compreende o ato sexual ou não. Esse deslocamento abre um novo campo de questionamento em torno da relação entre os indivíduos no que se refere a elementos que não eram trazidos para as discussões habituais sobre o amor, como a intensidade, o valor e a forma desse amor.

Nesse novo momento, aqueles três grandes domínios - a casa, a erótica e a econômica - voltam a ser a base da preocupação do homem da época imperial no que diz respeito ao corpo, aos familiares, à casa e, enfim, ao amor, só que agora nos termos de uma prática de si consigo mesmo, ao mesmo tempo que em uma relação indispensável com o outro. Toma-se o modelo de vida agrícola, praticam-se colheitas como forma de cuidado com o regime e com a dietética, para se passar à econômica. Sendo que esse modelo será definido no campo da família, com base nas relações familiares, podendo-se circunscrever a partir daí à questão do amor.

Resumindo, nessa paisagem da prática de si encontramos três domínios marcantes - um claro entrelaçamento da dietética com a econômica e desta com a erótica. E se esses elementos estão presentes no Alcibíades, Sócrates se atém à tarefa de definir que esse eu com que se deveria se ocupar era, naquela ocasião, a alma. Assim, ele deixava bem claro que, se era com a alma que se deveria se ocupar, não se deveria, logicamente, se ocupar com o corpo, nem com os bens, nem com a questão do amor, como pretendiam os enamorados de Alcibíades. Isso demostra que, nesse diálogo, o cuidado de si era apartado do cuidado com o corpo, do cuidado com os bens e do cuidado com o amor, ou seja, o cuidado de si, para Sócrates, se diferenciava totalmente da dietética, da econômica e da erótica. Mas agora, nesse 
período no qual estamos nos debruçando, vemos o retorno desses três domínios como uma espécie de superfície de reflexão do cuidado de si, como domínios de aplicação da prática de si em que o eu pode se experimentar, seguindo, com isso, um modo de existência específico, atendendo ao objetivo de se constituir como um eu determinado.

Para finalizar, Foucault vai destacar da mesma carta o trecho em que Marco Aurélio se descreve como "descarregando o fardo", que tem a ver com a ideia de exame de consciência, como trabalha Sêneca no De ira. Nesse contexto, o que mais vale recortar é a ideia da revisão obrigatória do dia que passou, do balanço que se faz das coisas na hora de dormir, uma revisão que permite avaliar se aquilo que foi feito vai de acordo ou não com o os compromissos assumidos consigo mesmo:

A própria carta, escrita na manhã do dia seguinte, nada mais é senão o que fez Marco Aurélio à noite, quando se deitou antes de adormecer. Ele descarregou o volumen de seu dia. Retomou o seu dia e o descarregou. Fez isso à noite, para si mesmo, fez na manhã seguinte, ao escrever para Frontão. Temos aí, portanto, pelo menos um exemplo bem interessante da maneira como a direção se tornava, estava em vias de tornar-se, havia já se tornado, desde algum tempo sem dúvida, uma experiência inteiramente normal e natural. Perante um amigo, um amigo que é caro, um amigo com quem se tem relações afetivas tão intensas, faz-se o exame de consciência. Toma-se-o como diretor de consciência e é totalmente normal tomá-lo como diretor, independentemente de sua qualificação de filósofo - e, no caso, não é um filósofo - simplesmente porque é um amigo (FOUCAULT, 2006a, pp. 2012).

Há uma atitude aqui em relação a si mesmo de prestação de contas para alguém, de relatar detalhadamente a alguém o dia vivido, mas o que Foucault vê de relevante em toda essa análise é que a prática de si vai estabelecer um tipo de relação social, para além da relação entre mestre de filosofia e aluno, que vai delinear uma nova ética, que vai circunscrever a parrhesía, que será traduzida por franqueza.

\subsection{A parrhesía}

O enunciado parresiástico abre um risco cuja reação é indeterminada. Seu traço principal, o que demarca o sujeito da parrhesía é que ele se coloca em risco quando enuncia determinada fala que confronta o poder. Trata-se de uma fala na qual o parresiasta abre mão da liberdade própria ao pacto social e se arrisca, abalando os acordos correspondentes a esse pacto, que, de modo claro ou velado, 
não oferecem grande abertura para serem analisados e criticados. Um exemplo na Antiguidade se refere a Platão - a enunciação parresiástica feita a Dionísio o irritou de tal modo que este o vendeu como escravo. O efeito da fala de Platão retirou-lhe parte da liberdade pessoal, risco característico da parrhesía. Na Modernidade, temos o exemplo de Galileu, que falava sobre descobertas científicas que afrontavam a igreja na época. Como seus enunciados desafiavam o poder da igreja, teve que abjurar - risco concernente ao gesto de enfrentar o poder, risco distintivo da parrhesía.

Segundo ponto que marca o enunciado parresiástico e que está presente nos dois exemplos citados é seu caráter público - seus efeitos aparecem. Minimamente, o risco que o caracteriza aparece. Não é uma fala entre amigos no sentido de uma brincadeira, é uma fala que tem um peso e que necessariamente causa algum efeito - a favor ou contra o parresiasta. Ou seja, ligado a isso, o terceiro ponto que define o enunciado parresiástico é a coragem de enunciá-lo. É claro que os três pontos cunham o enunciado parresiástico.

O enunciado parresiástico vai na contracorrente do enunciado performativo que caracteriza a nossa época. Aqui, no ato da enunciação, o sujeito está apenas cumprindo um papel, aquele que o aparato social oferece para ser cumprido. Não há riscos no ato desse tipo de enunciado, pois o que se fala é pertinente ao sistema, por mais que o conteúdo apresente elementos ligados a um gesto de rebeldia, por exemplo. De alguma forma, esses elementos são esperados, fazem parte da performance, da mesma forma que uma máquina em pleno funcionamento acaba produzindo algum resíduo que não vai cessar o seu movimento. Conta-se com isso. O enunciado performático não tem risco indeterminado, não tendo, portanto, que lançar mão de coragem, já que não se corre o risco de perder o lugar na engrenagem do aparato social, não havendo risco de perda de liberdade. O sujeito da performance é aquele que emite enunciados a partir de uma demanda provinda do aparato social sem se implicar com uma elaboração de si mesmo. Esse sujeito adere ao sistema e a suas codificações emitindo sobre si próprio e sobre os outros discursos formulados a partir dos elementos produzidos por esse mesmo aparato social. Não é à toa que profissionais que atuam como médicos, professores, engenheiros, juízes etc., na maior parte das vezes, não se implicam com a formulação de uma ética. 
A parrhesía é a ética do dizer a verdade em seu ato arriscado e livre. No cotidiano emitimos discursos a partir dos lugares sociais que ocupamos. A parrhesía pode operar como força de resistência ao status quo, que mantém uma série de discursos voltados para a manutenção de determinado jogo de interesses; no nosso caso, do capitalismo. Foucault ensina que não podemos deixar a história de lado ao problematizarmos questões sociais graves, como, por exemplo, a participação dos jovens negros de periferia no tráfico de drogas. O segredo que a sociedade manteria operando pode ser quebrado a partir da formulação de enunciados parrhesiastas, que apontariam os problemas históricos que os povos afrodescendentes enfrentam no nosso país e que dificultam o acesso desses mesmos jovens a condições concretas de existência como opção à entrada no tráfico ou em outros esquemas que acabam levando-os à morte ou a uma sobrevida, como detentos no sistema carcerário. As noções de jogos de verdade - parrhesía -, a resistência a determinadas formas de poder e a ideia de segredo que Foucault desenha em contrapartida à noção de inconsciente encontram-se, portanto, relacionadas. Não nos caberia lançarmos mão desses recursos para enfrentarmos a brutalidade cada vez maior com a qual assistimos esse espetáculo que se transformou os modos de vida neste mundo? Propomos uma reflexão pela via do cuidado de si e do outro, por meio de um equipamento afetivo - uma modificação dos modos de olhar para si e para o outro, quebrando esse acordo próprio do capitalismo que sustenta a noção de individualismo como virtude. Para nós, o individualismo é uma fantasia baseada em relações concretas, segundo as quais alguns ocupam os lugares mais favorecidos do aparato social enquanto outros trabalham, servindo como sua base de apoio, sem chances de trocar de lugar. Voltemos aos antigos e ao exemplo de paramentação estoica como ilustração de uma forma de cuidado.

\subsection{A paramentação estoica}

Para os estoicos, a paramentação é o preparar-se para se conduzir na vida como convém. Por exemplo, César não é o homem da paramentação, ele é guiado pelo "lance de dados". ${ }^{21}$ Um exemplo de paramentação no estoicismo é Marco Aurélio, que, ao se tornar imperador, vai se ver como o maior servidor de todos,

\footnotetext{
${ }^{21}$ Referência à Mallarmé.
} 
usando trajes considerados compatíveis com a posição ocupada exclusivamente nas ocasiões solenes, enquanto se vestia cotidianamente de modo rudimentar. A sua orientação é de estar preparado tanto para a fortuna quanto para o infortúnio a partir do cuidado de si mesmo, ou seja, de um trabalho de subjetivação que se norteie pelos afetos, pois compreende que o poder até pode dar a sensação de potência para quem alcança algum status social, por exemplo, mas que tal sensação é ilusória e só reproduz o próprio poder. O poder se apresenta tanto de forma terrível quanto de forma sedutora, mas, de uma forma ou de outra, o que ele reproduz é a si próprio. Nesse processo, alguns indivíduos aparecem sob nova forma, ganham novo status, e, em contrapartida, se comprometem com certas exigências, próprias a uma posição de poder.

Marco Aurélio, como estoico atento aos riscos próprios à posição de poder, cultivava a si mesmo norteado pelos afetos e pela subjetivação, entendendo que por essa via seria possível enfrentar o poder, pois a subjetivação dá os limites, paramentando aquele que luta contra as investidas do poder. Seria um modo de tomar a política a contrapelo; assim, quando o poder e o saber perdem valor, resta o afeto. O afeto como força capaz de resistir e de instaurar uma ética de si e do outro e, a partir daí, saberes, técnicas de si, um equipamento afetivo para lidar com o fato de estar vivo. O exemplo de Catão ilustra essa ideia. Antes de César, Catão foi convidado para ser imperador e, como não era permitido declinar da proposta, ele cria um modo de não a aceitar, pois amava a República (afeto). Ou seja, Catão desconversa, como modo de recusa, e se orienta pelos seus afetos. A história (saber) que narra a política pelo viés do poder não vai valorizar esse gesto, não lhe vai atribuir valor.

A epiméleia heautoû está ligada à franqueza, foi traduzida para o latim como "libertas", que é o cuidado do outro no sentido de governar o outro sem perder a liberdade. Catão, por amor à República, não pactua com o Império, e desconversa, não aceita a posição de imperador. Esse exemplo mostra que o governo de si não é dissociado do governo do outro. Catão assume seu afeto, não governaria o outro como imperador, pois esse gesto contrariaria seu afeto, aquilo em que acreditava. Mantendo-se no seu governo, ele manteve certo grau de liberdade, orientando-se a partir de uma ética de si. 


\subsection{0 cuidado de si e o domínio dos prazeres (enkráteia)}

No contato com o material referente aos gregos, Foucault vai sublinhar que, naquele mundo, havia o poder político, da pólis, a politea, e o poder econômico, o oikonomos, do oikos. Vai descobrir também um terceiro poder, que é a enkráteia, que na língua clássica significa uma forma de relação consigo mesmo que leve em conta uma atitude imperativa do sujeito em relação a seus prazeres, no sentido de dominá-los, para sua melhor fruição, o que caracterizava a moral pagã, em lugar de suprimi-los, como no modelo cristão. No paganismo, os sujeitos analisavam seus atos num plano real mais concreto, em sua forma clara e visível, em um plano de imanência; o que o diferencia da moral cristã, que teve como principal característica um processo de interiorização progressiva da regra, do ato e da falta, em uma relação do sujeito consigo próprio voltada para um outro.

Em nossa pesquisa de mestrado, sobre o livro História da sexualidade II: $o$ uso dos prazeres, pontuamos em vários momentos algumas aproximações e distanciamentos no que diz respeito a essas duas formas de moral. Fica claro que, para Foucault, não se trata de uma evolução da moral pagã para a moral cristã. Segundo ele, esse seria um modo simplificado de entender a transição de uma moral para outra. Pelo seu ponto de vista, o da relação consigo, o que se entende por moral cristã é um modo peculiar de relação consigo mesmo que compreende "formas precisas de atenção, de suspeita, de decifração, de verbalização, de confissão, de autoacusação, de luta contra as tentações, de renúncia, de combate espiritual etc." (FOUCAULT, 1994, p. 60).

A transformação do paganismo em cristianismo se dará em um longo período e vai consistir em uma reestruturação das formas da relação consigo mesmo e em uma transformação das práticas e das técnicas sobre as quais esse modo de relação consigo se fundava. O cristianismo desenha um corpo que descarta os prazeres na relação consigo, enquanto a moral pagã elabora uma atitude afirmativa em relação aos prazeres ao propor a enkráteia. Segundo Foucault:

Essa palavra [enkráteia] permaneceu por muito tempo bem próxima de sophrosune: elas são, frequentemente, encontradas juntas ou, alternativamente, com acepções bem próximas. Xenofonte, para designar a temperança - que faz parte, juntamente com a devoção, a sabedoria, a coragem e a justiça, das cinco virtudes que ele em geral reconhece -, emprega às vezes a palavra sophrosune, às vezes enkráteia. Platão se refere a essa proximidade das duas palavras quando Sócrates, interrogado por Cálicles 
sobre o que é "se comandar a si mesmo (auton heauton archein)", responde: consiste em "ser sábio e se dominar (sophrona onta kai enkrate auton heauton), em comandar os prazeres e os desejos em si próprio (archein ton hedonon kai epithumion)". E, quando, na República, ele trata de cada uma das quatro virtudes fundamentais - sabedoria, coragem, justiça e temperança (sophrosune)-, define esta última pela enkráteia: a temperança (sophrosune) é uma espécie de ordem e de império (kosmos kai enkráteia) sobre certos prazeres e desejos (FOUCAULT, 1994, pp. 60-1).

Com o cristianismo, essa forma de relação do indivíduo consigo mesmo dá lugar a outra forma de relação consigo, que desloca a atenção dos prazeres para uma investigação do corpo guiada pela mente, no sentido de detalhar os prazeres em suas minúcias, com o fim de eliminá-los. O corpo, entendido como sede das paixões, será cada vez mais depreciado. Deparamos então com o esboço de um futuro corpo dócil, já despotencializado em uma relação do sujeito consigo mesmo.

\subsection{Uma estética da existência no presente}

O giro que Foucault faz para a Antiguidade pode ser lido como um gesto criativo, que mostra o quanto a história do pensamento construiu suas bases sobre um modelo de sujeito que, delineado nos moldes de uma moral cristã, vem a ser regido por uma lei universal. Para Nietzsche, esse seria um sinal de fraqueza por parte do indivíduo, já que a falta de contato do indivíduo consigo mesmo, o investimento na ideia de uma salvação em uma possível vida após a morte, no qual se baseia o modelo cristão, o leva a se desviar do único caminho possível de constituição de si mesmo. Isso resulta na criação de um ego ilusório e de sua primazia, um egoísmo marcado, sem dúvida, por uma falta de gosto, já que exige do indivíduo a abdicação dos prazeres em nome de uma salvação futura. Esse ego forjado pelos valores morais de um modelo civilizatório assentado em uma moral cristã é um ego grosseiro que acaba desperdiçando a nossa capacidade de pensar. Segundo Nietzsche:

Quem ainda julga que "assim deveriam agir todos nesse caso" não chegou a andar cinco passos no autoconhecimento: do contrário saberia que não há nem pode haver ações iguais - que toda ação já realizada foi realizada de uma maneira única e irrecuperável, e que o mesmo se dará com toda ação futura; que todas as prescrições sobre o agir referem-se apenas ao grosseiro lado exterior (até as mais íntimas e sutis prescrições de todas as morais que houve); que com elas pode ser alcançada uma aparência de igualdade, mas somente uma aparência; que toda ação, contemplada ou reconsiderada, é e continua a 
ser algo impenetrável - que nossas opiniões acerca do "bom", "nobre", "grande" jamais podem ser demonstradas por nossas ações, porque toda ação é incognoscível; que, sem dúvida, as nossas opiniões, avaliações e tábuas de valores estão entre as mais poderosas alavancas da engrenagem de nossos atos, mas que, em cada caso, a lei de seu mecanismo é indemonstrável. Portanto, limitemo-nos a depurar nossas opiniões e valorações e a criar novas tábuas de valores: mas acerca do "valor moral dos nossos atos" vamos deixar de remoer pensamentos! Sim, meus amigos, é tempo de se enojar de toda tagarelice moral de uns sobre outros! Fazer sessões de julgamento moral deve ofender nosso gosto! Deixemos essa tagarelice e esse mau gosto para os que nada têm a fazer senão arrastar o passado um pouco mais adiante no tempo, e que nunca são, eles mesmos, presentes - para muitos então, para a maioria! Nós, porém, queremos nos tornar aqueles que somos - os novos, únicos, incomparáveis, que dão leis a si mesmos, que criam a si mesmos! (NIETZSCHE, 2001 p. 224).

O que nos interessa apontar a partir desse pensamento de Nietzsche é a tarefa de quebrar o costume de seguir códigos previamente estabelecidos lançando sobre eles falas vazias, enunciados performáticos, como se estivéssemos fazendo efetivamente alguma coisa. No lugar dessa "tagarelice moral" coletiva, propomos o investimento afetivo na existência: refletindo sobre as nossas condutas, a conduta de uns com os outros, questionando o que está dito como norma, afirmado como justiça, tudo isso nos gestos cotidianos, para que possamos nos implicar como sujeitos responsáveis pelo nosso tempo, nos constituindo como sujeitos no presente, em vez de nos mantermos em um lugar de passividade vitimada. Tal gesto instaura uma tarefa ética: a de produzir uma subjetivação, como sujeitos da performance emitindo falas vazias que, mesmo com um tom de paixão, acabam apenas mantendo tudo no mesmo lugar - ou como sujeitos da enunciação, como sujeitos parresiásticos. Por que o enunciado performativo mantém as coisas como elas estão? Porque, como aponta Nietzsche, quando o discurso se prende unicamente ao nível da moral, torna-se grosseiro e incapaz de operar transformações, não passando de um "remoer de pensamentos". A criação de si mesmo, com todas as possibilidades de confronto que necessariamente são geradas pela vida coletiva, estaria em uma direção ética de si e do outro.

\subsection{0 sujeito como salvação de si}

A salvação de si é uma das principais categorias da cultura de si, sendo aquilo a que visam as práticas de si mesmo. Ao mesmo tempo em que todos buscam atingir essa salvação, apenas alguns realmente conseguem concretizá-la. Trata-se de uma 
forma vazia e transitória que será moldada de acordo com o momento da vida. A salvação de si aparece na cultura antiga relacionada em parte aos movimentos religiosos e noutra, por ela mesma (FOUCAULT, 2006a, p. 157).

Isso desperta o nosso interesse no sentido de sabermos que nesse período houve uma cultura de si sobre um vazio ao qual se buscava dar forma. A nossa ideia aqui é, seguindo a crítica de Nietzsche sobre o tema do niilismo, vislumbrar um modo de existência que não vise a um grande sentido, e a subjetivação como prática de si ocorrida nos séculos I e II ilustra uma vida à qual se dá forma de acordo com os acontecimentos.

Na cultura do cuidado de si, o termo salvação é concebido como categoria filosófica, não tendo a carga religiosa que teria, por exemplo, para o cristianismo. No modelo cristão, a categoria da salvação é levada em conta no trato da questão da vida relacionada à morte, no sentido do drama do acontecimento de passagem da vida para a morte, o que faz com que esta adquira um certo peso negativo. A verdade produzida no ascetismo cristão tem como fundamento que a renúncia de si corresponda à condição que possibilita a ascensão a outra vida, à luz e à verdade, ou seja, trata-se de uma verdade de si que, no momento em que é produzida, institui uma renúncia de si. O que Foucault vai salientar é que, para os antigos, a categoria da salvação tem um peso, no sentido de um quilate. Não estava relacionada à ideia de escapar dos perigos ou das impurezas do mundo:

\begin{abstract}
"Salvar-se" significará: assegurar-se a própria felicidade, a tranquilidade, a serenidade etc. Vemos, porém, que, se, por um lado, "salvar-se" tem assim essas significações positivas e não remete à dramaticidade de um acontecimento que nos faz passar do negativo ao positivo, por outro lado, o termo salvação a nada mais remete senão à própria vida. Nesa noção de salvação que encontramos nos textos helenísticos e romanos não há referência a algo como a morte ou a imortalidade, ou um outro mundo. Não é por referência a um acontecimento dramático ou a um outro operador que nos salvamos. Salvar-se é uma atividade que se desdobra ao longo de toda a vida e cujo único operador é o próprio sujeito (FOUCAULT, 2006a, p. 226).
\end{abstract}

Sêneca dizia que o indivíduo, desde o ventre da mãe, não tem com a natureza a relação de vontade racional que define a ação moralmente reta e o sujeito moralmente válido. O que ele quer indicar com isso é que não se trata de formar um sujeito simplesmente a partir de um deslocamento em um plano de superfície de uma posição de não saber para uma posição de saber. Trata-se de um deslocamento 
profundo, no qual o indivíduo vai operar uma alteração de seu status de sujeito, visando a um lugar de alcance inteiramente novo, lugar de plenitude da relação de si para consigo. Inaugura-se um sujeito, ali onde não havia sujeito algum. Esse processo, em si, produz uma satisfação por parte do indivíduo, que se sente ativo, virtuoso, dando beleza à própria vida.

Esse exemplo grego, de uma constituição de si em um modelo de relação com o outro, pode delinear uma atitude ética de oposição em nossa época, cujo modo de vida aponta cada vez mais para uma direção frenética de consumo. O nosso tempo é marcado por uma fragmentação do sujeito, resultante de um jogo de interesses e de um investimento maciço na formação de uma opinião pública, elaborado por uma mídia ligada ao poder capitalista. Assim deparamos com subjetividades movidas por verdades exteriores a si mesmas, que não passam por um filtro seu, tornando-se assim presas fáceis do mercado. Essa postura não se pauta em uma ética voltada para o campo social, no qual nos enxergamos como grupo humano, mas sim pela lógica do mercado, de acordo com a qual uns são privilegiados por serem considerados cidadãos, e tratados como tais, enquanto outros são excluídos.

Nesse período dos séculos Ie II da nossa era havia uma preocupação em torno da questão de uma subjetivação passiva que fosse elaborada sem os critérios estabelecidos pelo cuidado de si. O aspecto de passividade, elemento do campo da subjetivação com que também nos deparamos hoje, interfere na formação de subjetividades por meio de uma opinião pública sustentada por sua vez pelo poder capitalista. Naquela época desenhou-se uma preocupação em relação à passividade que eles designavam por estado de stultia. Aqueles que não se ocupavam consigo mesmos nessa direção de salvação de si se rendiam ao estado de stultia, sendo o stultus aquele indivíduo aberto às representações do mundo exterior, de tal maneira que elas se confundem em seu espírito com seus desejos, suas paixões, ambições, ilusões e seus hábitos de pensamento. O risco de se voltar para si mesmo e entrar em contato com as fantasias e medos mais profundos pode até gerar o medo de se perder nas próprias fantasias, pode parecer, em alguns momentos, um caminho sem volta, ainda mais no nosso tempo, marcado como é pela divisão entre loucura e sanidade. No entanto, a tentativa de se preservar do contato com os aspectos mais primitivos da vida, como o medo da morte, por exemplo, a partir de uma adesão incondicional às convenções sociais e, portanto, aos apelos e valores oriundos do aparato social, de uma cultura que se diz voltada aos interesses de todos, é algo que 
não se pode fazer de olhos fechados, até porque, ao refletir sobre os valores e interesses impostos pelas convenções sociais, deparamos, como mostra Foucault nas análises do poder até os anos 1980, com os problemas de uma subjetivação articulada e explorada pelo biopoder.

Por essa via do cuidado de si, tal como estabelece Foucault, podemos identificar alguns pontos de transformação mais complexos que nos permitem pensar uma ética de si hoje como formação de um campo de subjetivação, no qual podemos problematizar o sujeito da enunciação e o da performance, a questão da maestria e do saber, tão atuais no que diz respeito à formação dos indivíduos, e o afeto, que, por se ligar ao tema do prazer, acaba não ganhando tanto espaço nas discussões filosóficas ou quando nos preocupamos em falar de ética. Mas, seguindo a trajetória de Foucault na sua Hermenêutica do sujeito, podemos entender que moral e ética geralmente fazem fronteira, o que resvala no tema do afeto, pois a moral cristã, que ganhou território no Ocidente, não abre espaço para os prazeres, abdica deles e ponto. No entanto, o modo grego de lidar com os prazeres que vai ser expandido e transformando no império - no qual se estrutura um domínio que nivela a dietética, a econômica e a erótica - por não atribuir maior peso aos prazeres sexuais, acaba tratando os maus hábitos de cada um não como alvo de uma prática punitiva, mas sim como norte de trabalho sobre si mesmo, de uma atitude ética de si consigo cujo principal objetivo consiste na criação de uma vida que tenha uma forma bela. Por essa via, não se prioriza uma atividade de condenação de si, como veremos posteriormente na atividade de perseguição dos pecados estabelecida pelo cristianismo. Desse modo, seria possível evitar um dos piores tipos de escravidão: a escravidão de si, no sentido de ser escravo das próprias paixões, ou seja, as paixões, longe de serem descartadas do âmbito moral, eram o material com o qual se entrava em contato, já que a atitude temperante se dava no confronto com elas.

Com isso, podemos ver que, no mundo helênico clássico, foi a partir do esquema do eu que se organizou o campo dos valores tradicionais. Apesar de o eu se apresentar como valor universal, ele era de fato acessível somente a alguns, já que só podia ser obtido a partir de uma série de exigências rigorosas, de práticas refletidas, relacionadas a todo um conjunto de noções que o incorporam a um modo de saber.

Assim, Foucault sustenta a ideia de que, a partir do período helenístico, vemos se desenvolver uma cultura de si. Para ele, não se pode dispensar o quadro dessa 
cultura de si de uma história da subjetividade, até porque ela vai atravessar o cristianismo, passando por algumas transformações, sem se apagar por completo. Alguns elementos dessa cultura de si, ao serem investidos pelo cristianismo, vão chegar a nossa época carregados de uma historicidade que não deveria ser desvinculada de uma reflexão sobre o sujeito, hoje. 


\section{A objetivação do sujeito na nossa época: o biopoder versus uma estética de si}

Como já foi dito, a pesquisa sobre a questão do cuidado de si emerge na sequênia das análises dos aphrodísia (História da sexualidade II), que não engendraram uma história da sexualidade focada, por exemplo, na noção de desejo, e sim na pesquisa de algumas questões referentes à moral e sua influência na formação do indivíduo moderno, principalmente após o trabalho realizado no curso Os anormais e nos livros História da sexualidade II: o uso dos prazeres e História da sexualidade III: o cuidado de si, que percorrem toda uma ramificação de saberes e mostram como o assentamento das bases que organizam a moral cristã foi complexo, não podendo ser explicado se não se levarem em conta práticas de poder e de dominação dos corpos, como, por exemplo, a articulação da pastoral cristã e a formação das populações. ${ }^{22}$

Foucault acaba organizando um trabalho sobre o material particular próprio aos aphrodísia. Essa noção acaba funcionando como uma chave, no sentido de abrir o pensamento referente à ideia do ser humano relacionado à moral, no sentido de um ser social formado, educado, treinado por um esquema moral. A varredura nesse material tão conhecido, tão estudado em diversas áreas da história do pensamento, trouxe à tona a noção de substância ética. E é principalmente a partir dela que se dá a virada para o eixo da estética nesse ponto da obra de Foucault.

Nos anos 1960, as obras de Foucault, Derrida e Deleuze se posicionam de forma transgressora em relação à filosofia tradicional. Foucault, atento à vida das pessoas, ao poder que se exerce sobre os indivíduos, se atém às experiências plurais, pela via da ideia de poder capilar, pois entende que onde há um conjunto de valores e regras haverá, por parte dos indivíduos, uma determinada conduta de acordo com a qual o sujeito vai se constituir como sujeito moral e se referir às normas. Atento às experiências marginais, aos comportamentos desviantes, Foucault propõe uma direção da imanência na qual o indivíduo, ciente de estar dominado por um poder, abre um espaço onde vai vigiar a si mesmo, para não ser conduzido cegamente pela vigilância do outro. Entram em cena o afeto, o engajamento e o social no jogo de

\footnotetext{
${ }^{22}$ Foucault marca a diferença entre o poder pastoral e o poder tradicional, no sentido de que este último sobrebuja-se aos dominados, enquanto o primeiro não pretende triunfar sobre o indivíduo, mas sim cuidar daqueles que estão sob seu domínio (FOUCAULT,2006b, p. 66).
} 
forças, como elementos a serem tornados favoráveis aos indivíduos. Segundo Foucault:

Dado um código de ação, e para um determinado tipo de ações (que se pode definir por seu grau de conformidade ou de divergência em relação a esse código), existem diferentes maneiras de "se conduzir" moralmente, diferentes maneiras, para o indivíduo que age, de operar não simplesmente como agente, mas sim como sujeito moral dessa ação. Seja um conjunto de prescrições sexuais que determina para os dois cônjuges uma fidelidade conjugal estrita e simétrica, assim como a permanência de uma vontade procriadora; mesmo nesse quadro tão rigoroso, haverá várias maneiras de praticar essa austeridade, várias maneiras de "ser fiel". Essas diferenças podem dizer respeito a vários pontos. Elas concernem ao que se poderia chamar de determinação da substância ética, isto é, a maneira pela qual o indivíduo deve constituir tal parte dele mesmo como matéria principal de sua conduta moral (FOUCAULT, 2006, p. 27). (aqui é História da sexualidade II. Tive que alterar as datas dessa trilogia na Bibliografia então é bom verificar...)

A apreensão da noção de sujeito pelo crivo da substância ética produz um furo no biopoder, permitindo pensar uma subjetivação delineada por uma estética de si tal como instaurada por práticas de si entre o grupo de filósofos estoicos, cínicos e epicuristas, que tinham como objeto principal o eu, que visavam garantir uma "realidade" aos seres do mundo a partir daquilo que afetava o indivíduo. Tratava-se de uma experiência rigorosa, conduzida por homens dedicados a tornar substanciais as experiências sentidas no decorrer da vida, tanto as prazerosas quanto as desagradáveis, evitando as saídas pelo escapismo, encorajados a assumir a vida em sua dimensão mais concreta e se elevar ao status de sujeito, dando brilho à vida.

A formulação do material referente à História da sexualidade, na qual verificamos a virada para a Antiguidade, produziu como um de seus efeitos um abalo da ideia de que o cristianismo inaugurou uma moral sexual que teria se mantido até a formação da moral sexual europeia moderna. Para Foucault, o que entendemos por moral cristã hoje foi a absorção, pelo cristianismo, de um conjunto de prescrições morais praticadas por vários grupos e voltadas para práticas de si rigorosas.

O que observamos nessa pesquisa é que não há essa continuidade, e sim uma série de linhas de força que desembocam na nossa época, com alguns pontos que fazem eco à ideia que temos sobre o cristianismo, o que nos mostra a presença de uma vontade de continuidade. O problema é que essa mesma vontade esmorece o 
desejo de transformação e cria graves problemas no que diz respeito às forças necessárias para a vida. O desejo de transformação e a aceitação de um estado de inquietação, como já propunha Sócrates, nos parecem capitais.

Quando Sócrates incitava seus concidadãos a cuidarem de si, estava se situando no lugar daquele que desperta. Desse modo, o cuidado de si fica associado ao momento do primeiro despertar (FOUCAULT, 2006a, pp. 10-11). E a ideia de um sujeito desperto não interessa ao poder em voga. Podemos pensar que esse movimento de conversão a si faz com que o indivíduo se ancore mais na realidade, passando a criar, nas condições concretas de sua existência, desafios pessoais, segundo os quais se empenhará em conquistar o que, para ele, são virtudes. Tudo que diga respeito ao modo singular pelo qual o indivíduo em questão está atravessando a vida, a instauração de uma perspectiva própria para lidar com a experiência de estar vivo e em negociação constante com as convenções sociais, o que o afeta e de que modo experimenta suas paixões diz da formulação de um campo subjetivo a partir de um poder que o próprio indivíduo exerce sobre si mesmo. Trata-se de uma modelação de si mesmo, não como uma renúncia de si, mas como uma transformação de si, fazendo da vida uma obra de arte. Desse modo, subjetividades são produzidas independentemente dos modelos externos e se torna a vida bela. No nosso mundo, temos sujeitos produzidos e treinados pela religião, pela família e pela escola. Em todas essas instituições os indivíduos vivenciam o mecanismo de recompensa e punição.

\subsection{O cuidado com a formação: a escola}

$\mathrm{Na}$ nossa época, a formação engendrada pelos modelos institucionais, ancorada em um aparato social mais amplo, tem como consequência a objetivação do sujeito. No caso das classes mais favorecidas, o indivíduo é orientado durante toda uma trajetória educacional para a escolha de uma profissão dentro de um campo de saberes que faz parte do conjunto de interesses relacionados ao estrato social ao qual pertence. Tanto os adolescentes na escola quanto os jovens que atravessam o ensino superior sofrem uma modelação subjetiva, podemos dizer assim, uma vez que não há um processo de aprendizagem neutro, já que poder e saber não se separam. Tomemos como exemplo o momento de preparação, uma espécie de ritual de passagem moderno da adolescência para a fase adulta, representado pela entrada na universidade - isso no caso das classes favorecidas, 
claro -, que se dá em cursinhos preparatórios, que ditam o material a ser absorvido, que vai ser reproduzido quase que automaticamente pelos alunos submetidos sob considerável pressão ao processo de seleção para o ingresso na etapa de ensino posterior. Seu foco se volta completamente para esse projeto de vida, e a família se mantém às voltas com um cuidado que vem junto de uma pressão maçante, já que o papel desse indivíduo passa a ser o de se manter passivo, absorvendo conteúdos, havendo uma inversão drástica entre as relações interpessoais e as horas de estudo. Esse formato pedagógico voltado diretamente para o mercado, que já tem sua primeira porta de entrada na universidade, incentiva o individualismo como fortaleza: o outro passa a ser uma ameaça nessa competição por vagas.

Se nos interrogarmos sobre a fragilidade que, inevitavelmente, esses alunos sofrem, a ameaça a seu narcisismo, em um momento em que os desejos e as fantasias, material tão potente, vindo da vida infantil, são moldados e objetificados por essas ideias de mercado, podemos pensar no paradeiro dessa fragilidade. Claro que, na nossa época, ela é degolada e negada tanto quanto possível, em nome desse personagem forte que tem que emergir, pois, se o objetivo final não é conquistado, o indivíduo é tomado literalmente como alguém que não tem valor, um ser descartável, que ainda terá que se virar sozinho com o que será considerado socialmente como um fracasso nessa etapa da vida em que essa meta deve ser alcançada. Esse ciclo pode durar anos. E quanto mais se vive nessa objetificação, mais o sujeito pode aderir a essa postura, passando a olhar o outro dessa forma. Só há reconhecimento de seus esforços se ele vence o vestibular: assim, ele passa a ser vangloriado, aplaudido e, lentamente, o ego fragilizado começa a se restabelecer numa velocidade brutal, sendo bombardeado de investimentos. Há toda uma expectativa em torno da ideia de reconhecimento.

Se recorrermos à noção freudiana de narcisismo, veremos que o indivíduo que infla seu narcisismo o faz como defesa, ao mesmo tempo em que tenta angariar alguma satisfação. Para isso, ele nega a alteridade. O outro, nessa concepção, se torna ameaça ou objeto inferior, sendo a princípio descartável, e ele o faz porque o outro pode retirá-lo de sua posição onipotente, trazendo-lhe receio de perder seu lugar alcançado. Assim, qualquer crítica a ele é negada tanto quanto possível. A marca do narcisismo está presente em todos nós, pois nos constitui, a questão é a quantidade de investimento que o sujeito faz sobre seu traço narcísico. Aqueles que lançam mão desse investimento em alto grau acabam sentindo satisfação no 
massacre do outro, portando um narcisismo perverso e exacerbado, o que acaba por refletir no caráter dos indivíduos, que repercute, por sua vez, nesse tipo de sociedade em que vivemos, onde os mais favorecidos se contentam em comprar, por meio da grande mídia, os saberes referentes às questões sociais, que deveriam ser tratadas por uma perspectiva ética estabelecida pelos interesses do mercado, que visam apenas ao lucro.

\subsection{0 cuidado com a saúde: a medicina}

Atualmente, o médico, que antes se implicava no cuidado das doenças, hoje passa a ser o fiscal do que se concebe como saúde. Seu papel é principalmente o de controlar as condutas consideradas específicas para a manutenção do bem-estar. Desse modo, o médico se torna uma figura determinante no quadro do biopoder. Sua formação, ligada à onipotência e, portanto, ao poder, replica-se em sua atuação. Todo o cuidado do sujeito doente é pautado na ideia de manutenção da vida, uma vida cada vez mais esvaziada e objetificada pela exclusão da subjetividade e medicalização desenfreada.

Se nos voltarmos para a filosofia clássica, vemos que Aristóteles já nos advertiu sobre a não dicotomização entre corpo e mente. Isso se perde, porém, diante do fenômeno do capitalismo desenfreado, sem nenhuma base ética, donde uma classe médica sustentada pela indústria farmacêutica e pelos planos de saúde. É a partir desses vínculos que vemos surgir novos paradigmas sobre os conceitos de normal e patológico, que, diante de um inegável jogo de interesses, acabam por manter a dependência e a alienação dos sujeitos, instaurando o domínio sobre seus corpos. A figura do médico investida pelo saber, ou seja, pelo poder, já que, pela perspectiva foucaultiana, ambos caminham juntos, situa o paciente no lugar de submissão àquilo que ele vai lhe informar. Complicado pensar em desenvolver empatia com o outro fragilizado, se, desde a formação escolar, o sujeito tem suas próprias fragilidades refutadas.

\subsection{O cristianismo e a atribuição do sentido de suspeita ao cuidado de si}

Foucault mostra que a assimilação do cuidado de si pelo cristianismo trouxe um tom de suspeita em torno do tema do cuidado consigo que acabou fazendo com que perdesse força no campo do conhecimento. Essa face do cuidado aparece 
definitivamente com a emergência desse modelo, não sendo encontrado no modo precedente. Para os antigos, aquele que se cuidasse como convinha sabia o que era ontologicamente, sabia que cuidava de si, sabia das próprias capacidades, sabia o que era ser cidadão integrante de uma cidade, sabia ser o dono da casa em um oikos, sabia definir um campo de reflexão das coisas nas quais acreditava e daquelas que desconsiderava, das coisas nas quais se envolvia, das coisas que podia esperar da vida, das coisas pelas quais não valeria esperar e, além de tudo, sabia enfrentar a morte com coragem. Isso dizia do governo de si como prioridade em relação ao governo do outro.

Esse campo reflexivo sobre o cuidado de si não oferecia o perigo que vemos se desenhar depois. A ideia de perigo vai ser circunscrita posteriormente no momento em que o amor por si próprio passa a se tornar motivo de suspeita quando associado às faltas morais. Doravante, o cuidado de si vai ganhar a forma de uma renúncia de si mesmo. O Traité de la virginté, de Gregório de Nissa, ilustra essa nova forma, aparecendo como renúncia a qualquer coisa que se possa entender como amor a si, amor à existência terrena. E o cristianismo vai ganhar força em cima do ponto de vulnerabilidade do sujeito do cuidado de si, perturbando toda a temática desse tipo de cuidado. Afinal, o medo da morte, da finitude, o assumir-se vulnerável está no âmago do cuidado de si.

A experiência mostra que o campo do conhecimento tal como engendrado a partir da Modernidade foi sendo organizado de modo que as nossas subjetividades foram passando por filtros institucionais legitimados pelos saberes instituídos, sempre pautados em uma base científica. Podemos dizer que, pela via da consciência e de suas limitações, verificamos uma "vontade de retidão". Uma produção de subjetividades não seria interessante para um sistema econômico como o capitalista, dado que, se houvesse criação por parte dos indivíduos, linhas autênticas de produção de si que começassem a questionar o campo das ciências, toda a epistemologia acabaria sofrendo um abalo. O mesmo também viria a ocorrer com a teologia, se nos ocupássemos, enquanto conjunto social, da questão de Deus, de resgatar a noção de espiritualidade e torná-la objeto do pensamento, com vistas a transformar a mais que desgastada ideia de psicologia. Assim também seria em relação à arte, se trouxéssemos a estética para o nível mais concreto da vida dos indivíduos, apresentando sua importância na vida cotidiana, na relação do indivíduo 
com o outro em termos de coletivo, tornando a vida um lugar mais frutífero. Podemos lembrar dos efeitos incontestáveis da experiência de Nise da Silveira. ${ }^{23}$

Assim, podemos entender que a análise dos aphrodísia abre um sulco, mais um caminho de pesquisa sobre os temas "sujeito" e "verdade", expandindo a formulação do problema para outros estratos de pesquisa, que levantam problemas tidos como já resolvidos pelas análises históricas habituais, que consideram que na Antiguidade não há espaço para se falar de sujeito de modo aproximado ao nosso modelo, e sim, unicamente, dos modos de vida derivados da epistrophé platônica e da metanóia cristã. Hoje pressupomos, desses modelos de subjetivação, a emergência de um status de sujeito que está para além dos modelos correntes.

A partir desse paradigma de sujeito, do que concebemos como o sujeito da Modernidade, adotamos os meios pelos quais vamos tentar reconhecer a emergência de outros modelos de sujeito em dado domínio histórico ou não. E se partirmos apenas das ferramentas que utilizamos para conceber o sujeito moderno, acabamos passando por cima, por exemplo, desse modelo de subjetivação antigo que, segundo Foucault, possibilitava ao indivíduo elevar-se ao status de sujeito. Tal formulação subjetiva não vinha de fora, por modelos estabelecidos em um ambiente externo ao campo da subjetivação, como é para nós. Podemos pensar que esse modo de subjetivação, na qual se cria um campo de produção de si, no nosso mundo, soaria uma atitude de rebeldia às instâncias detentoras do poder sobre a vida, às

\footnotetext{
${ }^{23} \mathrm{O}$ ateliê de pintura da Dra. Nise da Silveira, em sua experiência na seção de Terapêutica Ocupacional do Hospital Psiquiátrico Pedro II entre os anos de 1946 e 1974, ilustra o que estamos propondo aqui como abertura de lugares de ocupação de si e do outro em uma direção de cuidado, de troca, de abertura de múltiplas possibilidades de existência. O trabalho de Nise da Silveira resistiu bravamente àquilo que era considerado um "avanço" dos métodos de tratamento psiquiátrico: a lobotomia e o eletrochoque. Ela se ocupa dos esquizofrênicos pelo afeto. Criticada pelos cientistas da época, enfrentou seu tempo com armas artísticas e afetivas: uma dedicação aos clientes a partir de um equipamento afetivo e artístico. Suas armas: o envolvimento afetivo (afeto catalisador) e o pincel. Em suas palavras: "Era surpreendente verificar a existência de uma pulsão configuradora de imagens sobrevivendo, mesmo quando a personalidade estava desagregada. Apesar de nunca haverem pintado antes da doença, muitos dos frequentadores do ateliê, todos esquizofrênicos, manifestavam intensa exaltação da criatividade imaginária, que resultava na produção de pinturas em número incrivelmente abundante, num contraste com a atividade reduzida de seus autores fora do ateliê, quando não tinham mais nas mãos os pincéis. Que acontecia? Nas palavras de Fernando estaria possivelmente a reposta: "Mudei para o mundo das imagens. Mudou a alma para outra coisa. As imagens tomam a alma da pessoa". Se "as imagens tomam a alma da pessoa", entende-se a necessidade de destacá-las tanto quanto possível do roldão invasor. Pintar seria agir. Seria um método de ação adequado para a defesa contra a inundação pelos conteúdos do inconsciente. $\mathrm{O}$ ateliê de pintura me fez compreender que a principal função das atividades na Terapêutica Ocupacional seria criar oportunidade para que as imagens do inconsciente e seus concomitantes motores encontrassem formas de expressão. Numa segunda etapa viriam as preocupações com a ressocialização. $\mathrm{O}$ ateliê de pintura não cessa de levantar problemas, questões difíceis que obrigam o médico a refletir, a estudar (SILVEIRA, 1981, pp. 13-4).
} 
instituições responsáveis pelo cuidado dos indivíduos. ${ }^{24} \mathrm{Na}$ epistrophé platônica ou na metanóia cristã não havia abertura para a enkráteia. Mas havia esse grupo de filósofos que produziam um governo de si, uma administração de suas paixões na experiência concreta de vida neste mundo.

Foucault concorda com os historiadores e arqueólogos que demonstram que o gnôthi seautón tem a relevância de ter sido gravado em um ponto central da comunidade grega e, posteriormente, na região onde se encontra um centro da comunidade humana. No entanto, não se atribuía a ele o significado do "conhecete a ti mesmo" no sentido filosófico do termo, já que não fundamentava nenhuma moral, nem mesmo sequer o princípio de uma relação com os deuses.

O que os historiadores e arqueólogos deixam claro é que todos os preceitos délficos dirigidos àqueles que vinham consultar o deus eram vistos como um conjunto de regras, recomendações rituais, no tocante ao próprio ato da consulta. Vale lembrar alguns preceitos mais notáveis, como, por exemplo, a interpretação de Roscher, de 1901, do medèn ágan ("nada em demasia"). Para ele, tal preceito não correspondia à formulação de um princípio geral de ética e de medida no que diz respeito ao âmbito do comportamento. Voltava-se, na verdade, para situar o consulente no sentido de dimensionar a colocação das questões, filtrando-as, a fim de pôr apenas aquelas que fossem mais úteis. Outro exemplo é sobre os engye (as cauções), que recomendavam aos indivíduos não fazerem promessas no ato da consulta, para não se comprometerem com coisas que não pudessem cumprir depois. O gnôthi seautón também era integrado como um preceito, e o seu papel era de proporcionar um contato consigo mesmo, lembrando que, no momento de consultar o oráculo, se deveria manter certa precisão, cuidar em ver em si mesmo aquilo que realmente se necessitava perguntar.

Foucault recorre também às interpretações de Defradas, de 1954, encontradas no livro Os temas da propaganda délfica. Esse autor traça outra linha, um pouco diferenciada, mas que também não atribui ao gnôthi seautón o princípio de conhecimento de si, mas sim os assinala como imperativos gerais de prudência, também na relação consigo mesmo, no sentido de se ter uma preocupação em se redimensionar no que diz respeito às próprias limitações, características a todo

\footnotetext{
${ }^{24}$ Lembremos que, com o fenômeno das populações, os modos pelos quais se estabelece o cuidado com os indivíduos gira em torno de um poder sobre a vida e uma eficácia, no sentido de um controle da morte por meio dos saberes-poderes legitimados para operar estratégias de cuidado.
} 
mortal, para que assim evitasse se projetar como alguém que pudesse se atribuir as forças de um deus:

Segundo Defradas, estes três preceitos délficos seriam imperativos gerais de prudência: "nada em demasia" nas demandas, nas esperanças, nenhum excesso também na maneira de se conduzir; quanto às "cauções", tratava-se de um preceito que prevenia os consulentes contra os riscos da generosidade excessiva; e quanto ao "conhece-te a ti mesmo", seria o princípio [segundo o qual] é preciso continuamente lembrar-se de que, afinal, se é somente um mortal, e não um deus, devendo-se, pois, não contar demais com sua própria força nem afrontar as potências que são as da divindade (FOUCAULT, 2006a, p. 6).

Nesse breve apanhado de sentidos para o gnôthi seautón, o acento está no fato de a regra do "conhece-te a ti mesmo" ser formulada sob o princípio do "cuida de ti mesmo" (epiméleia heautô̂). Ou seja, a regra do conhece-te a ti mesmo era formulada em um plano mais geral do cuidado de si, da ocupação de si, como uma forma, uma aplicação concreta. Assim, desviando a questão do sujeito da fórmula do gnôthi seautón, estabelecido como eixo de sua emergência, Foucault vai se ater à questão da epiméleia heautoû, que perdeu importância devido, principalmente, à notoriedade alcançada pelo gnôthi seautón:

\begin{abstract}
Em um texto que logo adiante tentarei explicar com mais precisão (o famoso tex to do Alcibíades em sua última parte), veremos como a epiméleia heautô̂ (o cuidado de si) é realmente o quadro, o solo, o fundamento a partir do qual se justifica o imperativo categórico do "conhece-te a ti mesmo". Portanto, a importância da noção de epiméleia heautoû no personagem de Sócrates, ao qual, entretanto, ordinariamente se associa, de maneira, senão exclusiva, pelo menos privilegiada, o gnôthi seautón. Sócrates é o homem do cuidado de si e assim permanecerá. E, como veremos, em uma série de textos tardios (nos estoicos, nos cínicos, em Epicteto principalmente), Sócrates é sempre, essencial e fundamentalmente, aquele que interpelava os jovens na rua e lhes dizia: "É preciso que cuides de vós mesmos" (FOUCAULT, 2006a, p. 11).
\end{abstract}

Para Foucault, é fundamental voltar o olhar para essa diferenciação entre a epiméleia heautoû e o gnôthi seautón, restituindo à epiméleia heautoû seu papel, ou seja, circunscrevendo-a a partir de uma ação específica - a de uma atitude filosófica no decorrer de praticamente toda a cultura grega, helenística e romana. Essa atitude não se restringia a um sentido filosófico, mas, de maneira mais ampla, era considerada um princípio de conduta racional que se propunha seguir o 
princípio da racionalidade moral. Foucault posiciona essa incitação ao cuidado de si na ordem de um acontecimento do pensamento, já que se tornou um fenômeno cultural de conjunto típico das sociedades helenística e romana, em especial de sua elite. O que é importante ressaltar é o peso, no sentido de quilate, que se dava ao delineamento de um princípio de conduta para a vida.

Faz-se urgente relançar a ideia de cultura como categoria nos dias de hoje, principalmente diante da constatação nietzschiana sobre o ideal ascético. Não adianta pensar a violência da sociedade na qual nos encontramos apenas por medidas castradoras voltadas para a ideia de segurança e manutenção da vida da maioria das pessoas. Nesses termos, a divisão que se instaura é superficial, não considerando critérios éticos voltados para modos de vida menos brutais, principalmente nos territórios ocupados pelas classes desfavorecidas economicamente. Hoje, os intelectuais insistem em trazer à tona os problemas sociais, enredando-os em questões históricas graves e antigas que repercutem nas mais diversas calamidades sociais, noticiadas diariamente no formato de catástrofes sociais, pelas quais as classes favorecidas, sentindo a perda iminente de sua liberdade física e moral, de seus direitos, justificam cada vez mais o descaso em relação às classes desfavorecidas. Os membros desta classe, por sua vez, cientes de que são culpabilizados e não atendidos nos quesitos mais básicos no que se refere à ideia de cidadania, não se ocupam em preencher os requisitos equivalentes ao papel de cidadão em relação ao outro. Como resposta, vemos os indivíduos em constante revolta, tanto de um lado quanto de outro, e quanto mais falas revoltadas e vazias se constituem, mais dificuldade eles têm em lidar com o rito da lei, fundamental para a vida em comunidade no que diz respeito ao aspecto mais básico - o acesso à cidadania, à moradia na pólis, um êthos.

Levando em conta sua complexidade, sempre considerando as divisões de classe, o status social dos indivíduos, como o conjunto social os dispõe, de acordo com as atividades respectivas à classe social da qual fazem parte, das práticas estabelecidas como próprias a seu grupo, entendemos que a ideia de um trânsito livre dos corpos por tais demarcações sociais beira uma utopia, concebendo a noção de corpo, tanto individual quanto social, como política. Ou seja, a concepção de cultura deve estar intrinsecamente ligada à noção de lugar social. Mais uma vez, retomamos a filosofia foucaultiana, que mostra que são as práticas de poder-saber estabelecidas pelo modelo civilizatório que organizam o conjunto social e 
demarcam os lugares dos indivíduos e de suas práticas culturais. Para ampliar esse pensamento, vale lembrar que Freud não distingue os termos cultura e civilização (FREUD, 2014, p. 233). Para Foucault, faz-se necessário circunscrever precisamente o termo, até para percorrê-lo no plano de uma cultura de si. Uma vez que Foucault reconhece que, a partir da época helenística e romana, se desenvolve uma cultura de si, ele circuncreve as condições precisas para descrever o termo "cultura" segundo os critérios peculiares à filosofia foucaultiana, ou seja, pensando os saberes de acordo com os poderes, no caso, o trato do termo cultura tal como estabelecido em sua prática:

Como, de todo modo, não gostaria de empregar a palavra cultura em um sentido demasiadamente vago, diria que se pode falar de cultura, parece-me, sob certas condições. Primeiramente, quando dispomos de um conjunto de valores que têm entre si um mínimo de coordenação, de subordinação, de hierarquia. Pode-se falar de cultura quando atendida uma segunda condição, a saber, que esses valores sejam dados como sendo ao mesmo tempo universais, mas não acessíveis a qualquer um. Terceira condição para que se possa falar de cultura: a fim de que os indivíduos atinjam esses valores, são necessárias certas condutas, precisas e regradas. Mais que isso, são necessários esforços e sacrifícios. Afinal, é necessário mesmo poder consagrar a vida inteira a esses valores para ter acesso a eles. Por fim, a quarta condição para que se possa falar de cultura é que o acesso a esses valores seja condicionado por procedimentos e técnicas mais ou menos regrados, que tenham sido elaborados, validados, transmitidos, ensinados, e estejam também associados a todo um conjunto de noções, conceitos, teorias etc., enfim, a todo um campo de saber (FOUCAULT, 2006a, pp. 220-1).

Essa concepção de cultura se aproxima da ideia desenvolvida por Freud em O mal-estar na civilização e em O futuro de uma ilusão. Nesse texto, Freud marca a questão do sacrifício que o indivíduo precisa fazer para participar da comunidade humana. No mundo de hoje, onde cada vez mais se enfatiza o ganho acumulativo pelo viés individualista, pela via do consumismo, vamos perdendo o gosto pela ideia de um coletivo, de uma felicidade comum. Ora, por esse caminho, não é à toa 
que vemos se proliferarem pesquisas sobre distúrbios ligados à tristeza, e quase nada a respeito da felicidade.

O cuidado de si antigo delineava um gosto pela existência e a vida se voltava para a produção efetiva de uma estética de si. Havia, desse modo, uma experiência cotidiana de sacrifício de determinadas coisas em detrimento de outras. A experiência consigo mesmo era regulada por princípios de conduta, e esse hábito acabava proporcionando uma via de experiência com o outro na mesma ordem. Nos séculos I e II, essa cultura de si, do cuidado de si próprio, não gerava estranhamento quando pensado no outro, o que parece fato em um mundo tão individualista como o nosso, em que parece que os indivíduos se encontram adormecidos, às voltas com a ilusão do ideal ascético. Ao contrário do que parece, para a nossa época, o trabalho de uma cultura de si acaba trazendo à baila a reflexão de uma cultura no sentido de um coletivo. O exercício do sacrifício parece ser a chave para abrir nosso pensamento sobre cultura. Para Foucault:

Pois bem, parece-me que, se chamarmos cultura a uma organização hierárquica de valores, acessível a todos, mas também ocasião de um mecanismo de seleção e de exclusão; se chamarmos cultura ao fato de que essa organização hierárquica de valores solicita do indivíduo condutas regradas, dispendiosas, sacrificiais, que polarizam toda a vida; e, enfim, que essa organização do campo de valores e o acesso a esses valores só se possam fazer através de técnicas regradas, refletidas, e de um conjunto de elementos que constituem um saber, então, nessa medida, podemos dizer que na época helenística e romana houve verdadeiramente uma cultura de si (FOUCAULT, 2006a, p. 221).

Ou seja, mais uma vez, lembrando que Freud não distingue cultura e civilização, entendemos, como mostra Foucault, que a cultura parte de uma hierarquia e das disposições dos indivíduos nos estratos sociais, se estabelecendo nessas camadas.

$\mathrm{Na}$ esteira da genealogia de Foucault, vamos percorrer alguns aspectos relativos ao campo do cuidado de si, abordando-o por esse aspecto de acontecimento no pensamento, para que possamos lançar luz sobre algumas questões referentes ao sujeito da Modernidade. Lembrando que a filosofia foucaultiana concebe os acontecimentos em um jogo de forças, ele mostra que a epiméleia heautoû vai perdendo força, ao mesmo tempo em que o gnôthi seautón vai angariando espaço na cena das reflexões em torno do sujeito, a ponto de 
suprimir a epiméleia heautoû - tão importante nas práticas de si regulamentadas por esse grupo de filósofos durante um período expressivo da Antiguidade. O olhar que lançamos para a nossa história do sujeito não vai se dar livre de interesses, como aprendemos com Nietzsche, o que nos leva a refletir sobre a maneira pela qual buscamos apreender os fatos. Ou seja, os elementos que compõem essa história vão estar dispostos de modo a entronizar seus protagonistas - a história, ensina Foucault, vai se voltar para os vencedores, para os monumentos, para as grandes conquistas, apagando aquilo que é visto como pequeno, insignificante, como perda, como falha.

A história habitual não vai se ater aos seus paradoxos, mas, sim, vai buscar eliminá-los, se mostrando inteira, sem falhas. Por isso a importância de explorar as "falhas" da história, pois é numa fenda aberta no bloco da história, no sentido dos grandes feitos históricos, que podemos deparar com uma mina de ouro - o acontecimento.

O primeiro paradoxo considerado na pesquisa de Foucault indica que a epiméleia heautoû, esse movimento em direção a si mesmo, pode ecoar para o nosso tempo - um tempo marcado por episódios verdadeiramente pessimistas no que diz respeito a uma ideia de coletividade; como um traço próprio de um indivíduo derrotado nas tentativas de sustentar uma moral coletiva, que se contentaria com aquilo que lhe restara, ou seja, um retorno para si mesmo. A ocupação de si para consigo funcionaria como uma espécie de consolação para um indivíduo derrotado em seus anseios por uma vida coletiva satisfatória. Segundo Foucault:

Ora, em todo o pensamento antigo de que lhes falo, seja em Sócrates, seja em Gregório de Nissa, "ocupar-se consigo mesmo" tem sempre um sentido positivo, jamais negativo. Ademais - paradoxo suplementar - é a partir dessa injunção de "ocupar-se consigo mesmo" que se constituíram as mais austeras, as mais rigorosas, as mais restritivas morais, sem dúvida, que o Ocidente conheceu, as quais, repito (e foi nesse sentido que lhes ministrei o curso do ano passado), não devem ser atribuídas ao cristianismo, porém à moral dos primeiros séculos de nossa era e do começo dela (moral estoica, moral cínica e, até certo ponto, também moral epicurista) (FOUCAULT, 2006a, p. 17).

Observe-se que aquilo que, para nós, parece uma volta sobre si com ares de derrotismo e egoísmo, durante séculos fundamentara morais rígidas, funcionando como um princípio positivo. Esse é o primeiro paradoxo, uma virada no sentido daquilo que antes era concebido como algo repleto de valores positivos no campo 
de uma moral. Já o segundo paradoxo, seguindo ainda essa mesma linha de pensamento sobre o cuidado de si, aponta para o fato de essas regras terem sido recobradas tanto pela moral cristã quanto pela moral não cristã, sempre reordenadas num domínio que visava a uma ética geral do não egoísmo: na forma cristã, no modelo de uma abdicação de si; na forma moderna, no modelo de uma obrigação com os outros - o outro podendo ser a coletividade, a classe, a pátria etc. Assim, todo um conjunto de regras, toda uma história de práticas de si foi absorvida pela moral cristã, e também pela moral do mundo moderno, em um contexto que, ao priorizar a confirmação de um não egoísmo, foi descaracterizando a história de uma relação consigo realizada durante séculos.

O estudo dessas práticas nos leva a observar que elas estavam atreladas a um exercício do pensamento, nos moldes de uma elaboração de si na qual a formulação do pensamento resultava em algo substancial. Isso partindo de um si voltado para si mesmo, que, em contato com suas questões, medos, fantasias, angústias e vícios, buscava, em um processo de interlocução com um mestre, formar virtudes, aplicando-se em se manter firme e se preservar daquilo que ele mesmo trazia consigo do seu contato inevitável com as seduções vindas do mundo. O sujeito do cuidado de si refletia sobre os sofrimentos causados pelos golpes da vida, evitando se manter em um estado de inércia, o que o levaria a se situar passivamente, imerso nas fantasias do mundo, ficando exposto, sem nenhuma proteção aos discursos que emanavam das esferas de poder em voga. Essa situação passiva gera um estado conturbado, um esvaziamento, ao contrário de uma relação estabelecida de si consigo, capaz de tornar uma vida ocupada com a produção de virtudes - uma prática de si que assegurasse a existência de uma subjetivação. Sêneca dizia que aqueles que se vangloriavam de suas posições de poder não as haviam alcançado por terem percorrido uma trajetória de virtudes, mas, sim, por conta do "lance de dados". A história mostra que os domínios de poder não investem em um espaço para o cuidado de si.

\subsection{A salvação de si antiga refletida na Modernidade}

$\mathrm{Na}$ nossa época, tanto como no mundo antigo, dependendo de que modo se instaure um sujeito na própria existência, pode-se acabar se deixando levar pelo engodo que o discurso voltado para o poder representa. $\mathrm{O}$ que esse grupo de filósofos refletiu, ensinamento valioso, aliás, é que é impossível salvar-se a si 
mesmo se não se fabricarem recursos para lidar com a vida em si, furando as "garantias" oferecidas pelo tecido social, que se convertem em um conjunto de fantasias onipotentes que acabam por posicionar o indivíduo de modo vulnerável. A ocupação de si voltada para equipar o eu perante o jogo de forças do mundo, da própria existência, em uma espécie de posição estratégica no jogo da vida e da morte, encarando a vida como um jogo de forças das quais todos fazemos parte, é uma estratégia fundamental para se viver de modo virtuoso segundo a concepção de cuidado de si entre os estoicos, cínicos e epicuristas.

Os marcos cronológicos da pesquisa de Foucault sobre a noção de sujeito do cuidado antigo se localizam em torno dos séculos I e II de nossa era, essa fase sendo tomada enquanto um marco na história do cuidado de si como noção, prática e instituição. Situa-se no período em que se instala a dinastia augustiniana ou júlioclaudiana, até o final dos Antoninos, no que diz respeito à demarcação política. Já a demarcação filosófica vai do período do estoicismo romano, elaborado a partir de Musonius Rufus, até Marco Aurélio, isto é, época do Renascimento da cultura clássica, do helenismo, bem no momento da expansão do cristianismo e do surgimento dos primeiros grandes pensadores cristãos, Tertuliano e Clemente de Alexandria.

Foucault elabora o curso à altura das repercussões das lutas dos anos 196070 , e de todo um campo de pensamento formado ali. Um dos efeitos mais patentes é a constatação de que nem todos os indivíduos se submeteriam por completo aos poderes do Estado. A irrupção de diversos grupos, com toda uma potência criativa, como, por exemplo, o rock and roll, incita Foucault a engendrar uma linha de pensamento que amplia a ideia de conhecimento tal como concebido pela tradição, buscando subverter a abordagem que concebe o conhecimento como produto da consciência, pautado nos princípios da divisão mente-corpo. Esse desvio da ideia tradicional de conhecimento vai acabar esbarrando com o delineamento de um termo nunca estudado nas análises do poder. Deparamos com a noção de espiritualidade, contemplada por esse grupo de filósofos, e com o que, para eles, seria a sua função. Tal noção vem a ser entendida como substância ética própria ao sujeito, uma produção do indivíduo - indivíduo tomado por outro ângulo que não esse da divisão mente-corpo, esquema que vem organizar a noção de sujeito com o advento da Modernidade. 


\subsection{A epistrophé platônica e metanóia cristã}

O tema da conversão a si (ad se convertere) proposto por Sêneca, Plutarco e Epicteto se sustenta na ideia de um fluxo de existência pelo qual se retorna a si próprio no mesmo lugar, uma busca por uma habitação em si mesmo, diferentemente da orientação da alma, presente no texto do Alcibíades, em que o olhar deve se voltar para o elemento divino, para as essências e para o mundo supraceleste, onde se pode vislumbrá-las.

Foucault aponta que o trato do material relativo ao tema da conversão, elaborado no cerne da cultura helenística e romana, a partir de imagens como, por exemplo, a que está presente em uma resenha dos cursos na École des Hautes Études (1951, pp. 3-7), a imagem do pião, ${ }^{25}$ indica que a reflexão em torno do tema não se fazia por meio de uma conceituação bem construída, do emprego de noções fechadas. Tratava-se de um esquema prático rigoroso que servia para orientar a conduta em um movimento de volta para si mesmo, tendo como principal objetivo o cuidado para não se desviar de si mesmo. Foucault aborda o tema da conversão [se] convertere ad se (converter-se a si, voltar-se para si mesmo) - por considerar que, dentre as tecnologias do eu, essa foi a mais importante no Ocidente, e em especial no cristianismo, relevância essa que extrapola as fronteiras do campo da religião, adquirindo peso considerável tanto para a filosofia quanto para o campo da moral.

Nos primeiros séculos da era imperial, o tema da conversão era tema corrente, já que se encontrava no cerne de tecnologias de si antigas, como a epistrophé platônica e a metanóia cristã. Essas tecnologias do eu têm traços que as distinguem claramente. Por exemplo, a concepção de conversão a si na epistrophé platônica visava à obtenção de um conhecimento que tivesse a própria forma da reminiscência, a partir de um afastamento das aparências. Ou seja, o elemento da conversão, aqui, aparece a partir de um desvio das aparências e um posterior retorno a si mesmo, que se dá após a percepção de que se é ignorante. Portanto, a partir dessa constatação, torna-se fundamental reconhecer a necessidade de se voltar para si mesmo, em busca de se ocupar de si mesmo, para se conhecer, conhecendo o

\footnotetext{
${ }^{25} \mathrm{O}$ pião gira sobre si, mas gira sobre si justamente como não convém que giremos sobre nós. O que é o pião? É alguma coisa que gira sobre si por solicitação e sob o impulso de um movimento exterior. Ademais, girando sobre si, ele apresenta sucessivamente faces diferentes às diferentes direções e aos diferentes elementos que the servem de circuito. E, por fim, embora permaneça aparentemente imóvel, na realidade o pião está sempre em movimento.
} 
verdadeiro. A epistrophé platônica teria como finalização a condução de si mesmo à reminiscência, o retorno à pátria, às essências, à verdade, ao Ser. É claro que na cultura helenística e romana se atribuía importância ao conhecimento, mas não de maneira decisiva e fundamental como na epistrophé platônica. De acordo com Foucault:

\begin{abstract}
"Desviar-se", "virar-se na direção de si", "fazer ato de reminiscência", "retornar à própria pátria" (a pátria ontológica) são os quatro elementos desse esquema muito tosco da epistrophé platônica. De qualquer modo, vemos que a epistrophé platônica é comandada, primeiramente, por uma oposição fundamental entre este mundo e o outro. Em segundo lugar, pelo tema de uma liberação, de um desprendimento da alma em relação ao corpo, ao corpoprisão, ao corpo túmulo etc. Em terceiro lugar, enfim, pelo privilégio do conhecer. Conhecer-se é conhecer o verdadeiro. Conhecer o verdadeiro é liberar-se. E é no ato de reminiscência, como forma fundamental do conhecimento, que esses elementos se enlaçam (FOUCAULT, 2006a, p. 258).
\end{abstract}

O modelo da metanóia cristã, por sua vez, propunha toda uma mudança no pensamento e no espírito, em uma tentativa de abdicar o mais que possível de si mesmo em nome de uma salvação em outra vida. A metanóia cristã é um tipo de conversão que se dá de modo súbito, o que não quer dizer que não exija toda uma preparação, um percurso para alcançá-la, o dispêndio de um esforço. No entanto, havendo ascese ou não, esse tipo de conversão exige um único acontecimento, súbito, que necessariamente será um traço que vem caracterizá-lo. Para Foucault:

É preciso um acontecimento único, súbito, ao mesmo tempo histórico e metahistórico que, de uma só vez, transtorna e transforma o modo de ser do sujeito. Em segundo lugar - sempre no interior da conversão ou metanóia cristã -, nesse transtorno súbito, dramático, histórico/meta-histórico do sujeito, ocorre uma passagem: passagem de um tipo de ser a outro, da morte à vida, da mortalidade à imortalidade, da obscuridade à luz, do reino do demônio ao de Deus etc. E, por fim, em terceiro lugar, há na conversão cristã um elemento que é consequência dos dois outros, ou o ponto de cruzamento entre ambos, a saber, que só pode haver conversão na medida em que, no interior do próprio sujeito, houver uma ruptura (FOUCAULT, 2006a, p. 260).

Importante destacar aqui que, na conversão cristã, o eu deve renunciar a si mesmo, renunciando a si e nascendo de outra maneira, que não tenha a ver com seu eu anterior, com seus hábitos antigos, com nada que anteriormente dava sentido à vida daquele que renunciara a si mesmo. 
A conversão helenística e romana obedece a critérios distintos, em primeiro lugar no que diz respeito ao plano de imanência, já que esse modelo de conversão não opõe este mundo a outro. A ideia de liberação na cultura de si helenística e platônica não diz respeito a uma espécie de abdicação deste mundo, como na metanóia cristã, ou da liberação do "corpo-túmulo", como na epistrophé platônica. Tomava-se como meta o aspecto de dominação de si como uma dedicação a si mesmo, uma ocupação consigo mesmo, em que, em vez de se manter persistindo naquilo que não seria possível dominar, se volta para a abertura de um campo de possibilidades, onde seria possível exercer algum domínio sobre si mesmo. Preocupação com os elementos concretos da existência, tomada de responsabilidade com aquilo que se tem em torno de si. Esse modelo leva em conta a ideia de relação com o próprio corpo por uma relação adequada de si para consigo, em vez de o entender como uma prisão da alma, o que acaba por alimentar a ideia de ruptura com o corpo.

No lugar de uma ênfase no conhecimento, como no modelo platônico, ou de uma abdicação de si pela via de uma ruptura com o eu, como no modelo cristão, a conversão helenística e romana tinha como meta o exercício, a prática, o treinamento e a áskesis - conjunto que constitui o elemento essencial desse modelo de conversão. Nesse caso, a ideia de ruptura circunscrevia uma prática de si voltada para uma suspensão dos hábitos, vícios, enfim, tudo aquilo que ameaçava cercar e escravizar o eu. É no campo dos costumes do eu que deve haver uma cissura e uma abertura de possibilidades de transformação, tomando-o como meta. A ruptura é efetuada em torno do eu com aquilo que pode acarretar algum desvio do eu como meta, diferentemente do modelo cristão, que propõe uma ruptura de si consigo próprio nos termos de uma abdicação de si. Sêneca utiliza o termo fugere a se (escape de si mesmo) para falar de fuga e, segundo Foucault, é principalmente nos seus relatos que deparamos com o uso do termo, por exemplo, na sua sexta carta a Lucílio: "É incrível como sinto estar fazendo progressos atualmente. Não se trata somente de uma emendatio (uma correção). Não me contento em corrigir-me, tenho a impressão de que estou me transfigurando (transfigurari)". E, pouco depois nessa mesma carta, ele fala de "mutação de mim mesmo" (mutatio mei) (FOUCAULT, 2006a, p. 260).

O primeiro ponto que demarca a diferença da conversão helenística e romana em oposição à metanóia cristã diz respeito ao tema da ruptura do eu. Os exercícios 
que visavam a essa ruptura não iam então na direção de uma morte figurada do eu para dar lugar a outro. Eram exercícios rigorosos, por exemplo, indicados pelos termos fuga (pheúgein) e retiro (anakhóresis), cumprindo o objetivo de romper com aquilo que escravizasse o eu, que produzisse dependências no eu, dificultando sua expansão. A anakhóresis teria tanto o sentido de um exército que "bate em retirada" (anakhorêे), quanto o sentido de um escravo que foge para a Khôra, se libertando e transformando seu status de escravo. Na carta 8, Sêneca compara a filosofia em seu ato de incitar o sujeito a girar em torno de si mesmo ao gesto pelo qual, tanto no aspecto tradicional quanto jurídico, o mestre libertava seu escravo:

Havia um gesto ritual, com que o mestre, a fim de mostrar, manifestar, efetuar a liberação do escravo de sua sujeição, fazia-o girar em torno dele mesmo. Sêneca retoma essa imagem e diz que a filosofia faz com que o sujeito gire em torno de si mesmo, mas para o liberar. Portanto, ruptura para o eu, ruptura em torno do eu, ruptura em proveito do eu, mas não ruptura no eu (FOUCAULT, 2006a, pp. 261-2).

Outro ponto de diferenciação entre a conversão helenística e romana e a metanóia cristã se relaciona ao tema do "olhar para si próprio", ao contrário do modelo cristão, que investe na direção do olhar para uma outra vida, desfocando desta. Por último, Foucault destaca o eu como meta, no sentido de que, para além dos olhos, o ser como um todo, o ser inteiro deve se dirigir ao eu como principal objetivo. Cito Foucault:

Ir em direção ao eu é, ao mesmo tempo, retornar a si: como quem volve ao porto ou como um exército que recobra a cidade e a fortaleza que a protege. Também aí há uma série de metáforas sobre o eu-fortaleza - o eu como o porto onde finalmente encontramos abrigo etc. -, mostrando bem que o movimento pelo qual nos dirigimos para o eu é ao mesmo tempo um movimento pelo qual a ele volvemos (FOUCAULT, 2006a, p. 262).

Fica nítido o destaque fornecido ao eu nessa prática de conversão helenística e romana, como vimos pelas várias vias de acesso que pudemos tomar aqui. No entanto, esse esquema prático deixa algumas brechas, nos mantendo em dúvida com relação ao fato de o eu ser algo a que se retorna por ser já dado, ou se o eu seria uma meta capaz de ser atingida caso esses exercícios fossem efetivamente cumpridos. Diante desse problema, Foucault destaca que o que mais interessa nesse modelo de conversão é menos o que caracteriza o movimento de conversão, ou seja, 
se o eu é tomado como o lugar para onde se deve voltar, ou se o eu é considerado como o lugar para onde se deve se dirigir, mas, principalmente, seu ponto de chegada e de realização. Relação de respeito e honra ao eu, relação que se espelha na relação de Estado, tomando-se como senhor de si, o eu pertence a si próprio como em uma relação jurídica e, ainda, como nas relações de prazer, gozo e deleite obtidas a partir do próprio eu. Nesse modelo, a conversão para o eu é a meta para a qual se dirige, é o foco principal do olhar, sendo consolidado como um objetivo a alcançar ou para o qual regressar. O que está em jogo no modelo de conversão estabelecido nos séculos I e II tem uma base bem diferente da conversão delineada na metanóia cristã, já que esta fixa uma meta de ruptura no próprio eu, de mudança no interior do eu. A conversão helenística e romana não se dá de modo súbito, ela conta com um processo longo e ininterrupto, que Foucault chama de autossubjetivação, no lugar de transsubjetivação. Essa autossubjetivação trata de colocar o sujeito como aquele que, ao fixar-se a si mesmo como meta, empenha-se em manter consigo mesmo uma relação adequada e primorosa. Ou seja, trata-se de uma espécie de vida autoafeccionada pelo próprio eu, algo bem diferente da metanóia cristã, que direciona o investimento do sujeito para o ideal de uma salvação em uma vida após a morte.

À guisa de esclarecimento do termo metanóia, não nos textos cristãos, e sim no vocabulário filosófico, Foucault afirma que o termo era utilizado de maneira negativa, e só veio a adquirir um sentido positivo, representando uma modificação do sujeito por ele mesmo, a partir de textos bem mais tardios, dos séculos III e IV, no sentido de a filosofia servir como um preparo para a vida, como uma prática na qual se toma uma direção de prudência, de abstenção de palavras e ações imprudentes que levariam ao arrependimento:

O arrependimento é, pois, alguma coisa a evitar e é porque devemos evitá-lo que há coisas a não fazer, prazeres a recusar etc. Portanto, devemos evitar a metanóia como arrependimento. Com isso, pretendo mostrar que, a meu ver, não podemos assimilar o que está em questão nessa temática da conversão a si, do retorno a si, a uma metanóia como conversão fundadora por meio de uma total reversão do próprio sujeito, renunciando a si e renascendo a partir de si. Não é isso que está em causa. No sentido de ruptura consigo, de renovação de si com valor positivo, a metanóia é encontrada em textos bem mais tardios. Não me refiro, é claro, aos textos cristãos, que, a partir do século III ou, pelo menos, da instauração dos grandes ritos de penitência, conferiram à metanóia um sentido positivo (FOUCAULT, 2006a, p. 264). 
Diferenciando-se desses modos de vida, Foucault pinça o sujeito da parrhesía, que parte de uma prática de si, que tem como meta final o eu, e que não mais se define como um preceito para a entrada em uma fase específica da vida, ligada à pedagogia e à política, mas sim para a vida inteira, numa espécie de arte de viver (tékhné toû bíou). O eu como elemento da conversão nesse tipo de prática de si se diferencia principalmente dos modelos de vida anteriormente citados, principalmente por se tratar de uma salvação de si, tendo nosso mundo como plano de imanência:

A conversão que encontramos na cultura e na prática de si helenística e romana não se move, primeiramente, no eixo de oposição entre este mundo e o outro, como a epistrophé platônica. Ao contrário, trata-se de um retorno que se fará, de certo modo, na própria imanência do mundo, o que não significa, contudo, que não haverá oposição essencial - e realmente essencial - entre o que não depende e o que depende de nós. Porém, enquanto a epistrophé platônica consistia no movimento capaz de nos conduzir deste mundo ao outro - do mundo daqui de baixo ao de cima -, a conversão de que agora se trata, na cultura de si helenística e romana, conduz a nos deslocarmos do que não depende de nós ao que depende de nós (FOUCAULT, 2006a, p. 258).

A conversão a si helenística e romana pressupõe um passo em direção à realidade, um entendimento de si a partir das próprias limitações, fronteira entre aquilo que é possível dominar e o que não é; pressupõe desenvolver a capacidade de aceitar este mundo e a criação subjetiva sobre o que se pode fazer de concreto. Em vez de se liberar da relação com o corpo, como na epistrophé platônica, a conversão a si helenística e romana busca criar as mais adequadas condições possíveis para se estabelecer uma relação consigo. O conhecimento, na epistrophé platônica, na forma da reminiscência, constitui o elemento essencial dessa forma de conversão. Na conversão helenística e romana, o elemento essencial se engendra na prática em si, no exercício, em um treinamento que exige um certo rigor, na áskesis.

\subsection{Aspectos particulares da prática de si helenística e romana}

O deslocamento da fase adolescente para a fase adulta que caracteriza a prática de si helenística e romana define aspectos particulares na relação mestrediscípulo que não pode passar desapercebido, pois a prática de si helenística e romana se dá necessariamente em uma relação com um outro - outro, não no 
sentido de um Outro, como, por exemplo, o deus da metanóia cristã, ou alguma espécie de ideal, como o conhecimento puro da verdade na epistrophé platônica. Como visto há pouco, o par mestre-discípulo vai se expandir em uma rede de relações plurais atravessadas de maneira multiforme. Todavia não é esse o ponto principal de transformação. Digamos que essa é uma nova cena, com novos protagonistas, em que se multiplicam práticas e discursos. Mas o que vale ressaltar, por ora, é a ênfase na formação de um eu que se formula em torno de si, para si, e não um eu impreciso, sem um foco. Nosso interesse nessa prática de subjetivação antiga se dá por pensarmos nesse modelo como uma subjetivação capaz de, ao ser transposta para o nosso mundo, servir como recurso que nos permita ultrapassar a perspectiva moral, que, para nós, por ser limitante, acaba abrindo margem para pontos de vista conservadores, uma vez que fecha o espaço de reflexão, apontando para o que é certo e errado, a partir das categorias de bem e mal. Esse tipo de crivo moral é extremamente perigoso para avaliar as complexas situações da vida. A tomada do eu como eixo da própria vida não quer dizer o que nós hoje entendemos como egocentrismo, já que não possui uma carga moral. $\mathrm{O}$ eu do cuidado de si é formulado em uma relação com o outro, pois, ao se ocupar consigo, também se ocupa de um outro. Segundo Foucault:

É preciso ocupar-se consigo para si mesmo, de maneira que a relação com os outros seja deduzida, implicada na relação que se estabelece de si para consigo. Lembremos que o próprio Marco Aurélio não ficava mais atento a si para poder melhor assegurar-se de estar atento, como convém, ao Império, isto é, ao gênero humano, em suma. Mas ele bem sabia que estaria atento, como convém, ao gênero humano que lhe fora confiado, na medida em que, desde logo e antes de tudo, finalmente e ao cabo, soubesse cuidar de si mesmo como convém (FOUCAULT, 2006a, p. 254).

Observamos, nessa conversão a si, a instauração de uma espécie de eixo de si na existência, a partir de um conjunto de tarefas empreendidas pelo desenho de um campo subjetivo no contato consigo mesmo (Epicteto, Marco Aurélio, Plotino: epistréphein pròs heautón - voltar-se para si, converter-se a si -; Sêneca: [se] convertere ad se-converter-se a si).

Uma genealogia da subjetividade nos leva a encontrar traços do sujeito formado pela pastoral cristã. E, nesse ponto, deparamos com o Foucault leitor de Nietzsche, que atenta para o ideal ascético como um dos maiores investimentos 
feitos pela nossa civilização. Para Nietzsche, o niilismo não nasce com o cristianismo; na verdade, ele tem sua base engendrada em processos anteriores, sendo finalmente potencializado com o avanço dessa religião. $\mathrm{O}$ papel do cristianismo foi o de uma sistematização e universalização de determinados pontos desenvolvidos por determinadas formas de moral, não apenas oriundas do ascetismo platônico, como se costuma entender, mas também estabelecidas nessas técnicas de si rigorosas. As forças do cristianismo investiram a cultura ocidental em uma direção antagônica à vida, em uma espécie de processo civilizatório incompatível com a vida, sendo um de seus pontos o da aniquilação de si, já que a partir da tomada de uma moral de finalização do eu, buscou-se aniquilá-lo, segundo a ideia de combater qualquer coisa que se assemelhasse a um egoísmo. Nas palavras de Foucault:

Cada vez mais a tékhne toû bíou (a arte de viver) vai agora girar em torno da pergunta: como devo transformar meu próprio eu para ser capaz de aceder à verdade? Daí se compreende também o fato de que a espiritualidade cristã, a partir dos séculos III-IV, ao desenvolver-se em sua forma mais rigorosa, no ascetismo e no monasticismo, poderá muito naturalmente apresentar-se como a consumação de uma filosofia antiga, de uma filosofia pagã que, a partir do movimento que lhes acabo de indicar, já era inteiramente dominada pelo tema da catártica, ou pelo tema da conversão, ou da metanóia. A vida da ascese, a vida monástica será a verdadeira filosofia, o monastério será a verdadeira escola de filosofia e isso, repito, na linha direta de uma tékhne toû bíou que se tornara uma arte de si mesmo (FOUCAULT, 2006a, p. 219).

Com o cristianismo, a ideia de salvação, que estava completamente associada ao conjunto de técnicas de si, foi assimilada pelo contexto religioso e deslizou para a ideia de salvação por um Outro, idealizado na figura de deus. Isso gera consequências bem atuais, já que repercute em um posicionamento passivo dos sujeitos, desencadeando, por sua vez, um esvaziamento ético no seio das relações humanas. Com o capitalismo, temos como agravante o vício ao consumo exacerbado. A dependência que os atores sociais têm uns dos outros fica descaracterizada e as relações manipuladas pelo capitalismo acabam favorecendo aqueles que têm maior poder aquisitivo e extirpando qualquer traço de cidadania daqueles que não acessam os maiores quinhões do capital. Ainda mais grave é que, a partir dessas práticas de poder, instauram-se saberes que justificam até mesmo o genocídio daqueles que vivem à margem do conceito de cidadania, por serem 
considerados os responsáveis pelo mal-estar dos mais favorecidos socialmente, já que são nomeados cidadãos violentos.

A instauração de um campo de subjetivação que possa resistir ao poder, a partir de um campo de fala, de troca entre os atores sociais, que venha trazer à baila a complexidade própria a qualquer conjunto social, pode ser traduzida como abertura de um campo ético. Para isso, faz-se necessário um certo grau de esvaziamento da ideia de consumo associada à força e à potência do campo subjetivo. A ideia de um retorno para si mesmo se orienta a partir da constatação de que esse tipo de poder capitalista nos afasta de possibilidades concretas de satisfação, nos conduzindo a um modo de vida totalmente ilusório, solitário e, cada vez mais, violento, por qualquer ângulo que tentarmos oa apreender.

\subsection{Um traço da temática da Modernidade entre os antigos: o sujeito e a lei}

Os cursos de Foucault do Collège de France contêm duas partes que situam o leitor no contexto da obra do autor. Destacamos um trecho do curso A hermenêutica do sujeito descrita por Frédéric Gros, por entendermos essa passagem como uma convocação a uma ética; papel que, para nós, pode ser engendrado no campo da filosofia. Segundo Gros:

Penso que há aí a possibilidade de elaborar uma história daquilo que fizemos e que seja ao mesmo tempo uma análise que tenha um sentido político - quero dizer, uma análise que tenha um sentido para o que queremos aceitar, recusar, mudar de nós mesmos em nossa atualidade. Trata-se, em suma, de partir em busca de uma outra filosofia crítica: uma filosofia que não determina as condições e as possibilidades indefinidas de transformação do sujeito (FOUCAULT, 2006a, p. 638; grifo meu).

A convergência de três correntes de pensamento no seio desse império nascente faz surgir na perspectiva de Foucault uma terceira corrente: a temática da Modernidade na Antiguidade. Essa corrente aparece no ponto de vista da história tradicional, sempre em uma tensão, acabando por se confundir ora com o neoplatonismo ora com a metanóia.

O curso A hermenêutica do sujeito é denso e complexo. Foucault levanta aí uma série de questões, sem se preocupar em traçar uma linha de raciocínio rígida, como se quisesse nos fornecer algum tipo de desfecho sobre a questão do cuidado 
de si na Antiguidade, como se fosse possível oferecer alguma luz às questões, não pouco urgentes, sobre o cuidado de si, o cuidado dos indivíduos consigo mesmos na nossa época, num mundo onde a ética de si e do outro se encontra cada vez mais fragmentada. Voltando-nos para esse problema e imersos em tantos elementos sobre o cuidado de si antigo traçados nesse livro, foi preciso, para efeito deste trabalho, recortar alguns trechos e aprofundá-los, para enfim tentar obter os insights tão fundamentais, quando, realmente, a proposta é fincar os pés em uma empreitada filosófica.

Em uma das aulas, Foucault relaciona o cuidado de si antigo com a questão da lei, cotejando o significado da lei no âmbito desse cuidado, guardadas as proporções que a lei tomou para nós, modernos. Na aula de 13 de janeiro do curso de 1982 Foucault esclarece que empreende a leitura do Alcibíades, não como um marco histórico que serviria como ponto de partida para traçar toda uma história do cuidado de si em Platão. Apoiando-se nesse diálogo como ponto de referência para a formulação do problema da subjetivação, Foucault delineia parte do problema no âmbito da filosofia clássica para posteriormente retraçá-lo no contexto da época helenística e romana (período imperial). Na leitura do Alcibíades Foucault se atém ao problema da relação entre o gnôthi seautón e a epiméleia heautoû. A problematização de Foucault gira em torno da interpelação de Sócrates a Alcibíades, quando este, interessado em governar a cidade, escuta de Sócrates que, para se ocupar da cidade, teria primeiro que aprender a cuidar de si mesmo. Quando Foucault formula as questões da subjetivação no período imperial, mostra que o cuidado de si sofre um descolamento da finalidade, que era imprescindível na época clássica. Foucault afirma que essa ideia pode ser interpretada nos moldes de um princípio universal imposto a qualquer um. Essa transformação da forma do cuidado leva Foucault a traçar uma questão, ao mesmo tempo histórica e metodológica, a saber: se o cuidado de si teria atingido o formato de uma lei ética universal. Diagnosticamos imediatamente um tom irônico na colocação dessa questão, já que não é por essa perspectiva que Foucault problematiza os acontecimentos, ao que ele vai dizer:

O que eu gostaria de mostrar, o jogo metodológico de tudo isso (ou pelo menos de uma parte) é o seguinte: não devemos nos deixar prender ao processo histórico posterior que se desenvolveu na Idade Média, e que consistiu na juridicisação progressiva da cultura ocidental, juridicisação que 
nos fez tomar a lei como princípio geral de toda regra na ordem da prática humana. O que eu gostaria de mostrar, ao contrário, é que a própria lei faz parte, como episódio e como forma transitória, de uma história bem mais geral, que é das técnicas e tecnologias das práticas do sujeito relativamente a si mesmo, técnicas e tecnologias que são independentes da forma da lei e prioritárias em relação a ela. No fundo, a lei não passa de um dos aspectos possíveis da tecnologia do sujeito relativamente a si mesmo. Ou, se quisermos, mais precisamente ainda: a lei não passa de um dos aspectos desta longa história no curso da qual se constituiu o sujeito ocidental tal como hoje se nos apresenta (FOUCAULT, 2006a, pp. 138-9).

Se a expressão "cuida de ti mesmo" parece ter se tornado universal, pelo fato de ter se tornado pontual, e não mais vinculada a alguns indivíduos para uma finalidade determinada, isso não quer dizer que essa forma de cuidado tenha se tornado uma lei geral. Tal prescrição só pode ser posta em prática por uma quantidade restrita de indivíduos, como descrito na sentença lacedemônica, em que se afirma ter confiado a cultura de suas terras ao hilotas para que se pudesse ocupar consigo mesmo. Ou seja, a ocupação consigo mesmo era considerada uma atividade peculiar da elite. No início do período imperial só é possível ocupar-se consigo se há, na vida, espaço para o otium. O ócio dá à vida um tom particular, diferenciandoa das vidas comuns, sendo condição primordial do cuidado de si. O cuidado de si na cultura greco-romana não diz de uma lei universal válida para qualquer indivíduo em qualquer modo de vida. Há um rigor que o afirma apenas em condições específicas de vida. Há necessariamente a escolha de um modo de vida, uma demarcação entre aqueles que escolheram um modo de vida e aqueles que não o fizeram.

Outro ponto que evidencia que o cuidado de si não se ajustava aos moldes de uma lei universal diz respeito ao fato de que se formavam, em grupos fechados, práticas e instituições notoriamente distintas entre si, que não trocavam umas com as outras, que, geralmente, se excluíam. Importante verificar que o cuidado de si tem principalmente o traço de um comportamento, ou seja, o fato de o indivíduo fazer parte de uma aristocaracia não lhe assegurava maior acesso a essa prática. Alguns indivíduos de classes baixas, excluindo geralmente os escravos, também buscavam a ocupação consigo mesmos, como, por exemplo, no caso de cultos religiosos, especialmente voltados à existência, grupos altamente organizados, voltados para cultos definidos por uma ritualização rigorosa. Esse caráter cultural e ritual dispensava em parte as formas mais rebuscadas e eruditas da cultura pessoal 
e da investigação teórica. Essa maneira de viver a experiência religiosa se diferencia da que veremos se constituir posteriormente com o advento do cristianismo, pois os antigos atribuíam mais valor ao caráter cultural e ritual, em vez de conferir peso aos aspectos relacionados à cultura pessoal e à investigação teórica:

O quadro religioso e cultual dispensava um pouco esse trabalho individual ou pessoal de investigação, de análise, de elaboração de si por si. Entretanto, a prática de si, nesses grupos, era importante. Em cultos, por exemplo, como o de Ísis, a todos os participantes impunham-se abstinências alimentares muito precisas, abstinências sexuais, confissão dos pecados, práticas penitenciais etc. Pois bem, no outro polo extremo desse leque, encontramos práticas de si sofisticadas, elaboradas, cultivadas, que, evidentemente, são muito ligadas a escolhas pessoais, à vida de ócio cultivada, à investigação teórica. Isso de modo algum significa que essas práticas fossem isoladas. Faziam parte de todo um movimento que poderíamos denominar "da moda". Apoiavam-se também, senão em organizações cultuais bem precisas, pelo menos em redes socialmente preexistentes, que eram as redes de amizade (FOUCAULT, 2006a, p. 141). ${ }^{26}$

Foucault quer com isso mostrar a forte presença de toda uma rede social, em parte institucionalizada, que, salvo as comunidades cultuais descritas acima, foi um dos suportes primordiais da prática de si. Destarte, são dois os principais polos da prática de si: um que pode ser considerado mais rude, voltado para o popular, religioso, cultual, e outro mais voltado para os cuidados da alma, cuidados de si, práticas de si, mais articulados nos meios mais favorecidos, que se assentavam nas redes de amizade. Essa divisão, no entando, não deve ser tomada ao pé da letra como se se tratasse de duas categorias: por um lado, uma rude e popular, e de outro, uma erudita e cultivada. Um desses exemplos é a rede dos epicuristas, que não consistia em grupos religiosos, e sim filosóficos, que vinham da Grécia, de comunidades populares compostas por artesãos, comerciantes menores, pequenos agricultores - encarnando uma escolha política democrática, diferente da escolha

\footnotetext{
${ }^{26}$ Divindade egípcia, Ísis é conhecida principalmente por ter reunido os pedaços do corpo de Osíris, em uma famosa lenda cuja narrativa completa encontra-se em Plutarco (Oeuvres morales). Nos primeiros séculos da nossa era, seu culto (ela é, ao mesmo tempo, a mulher ardilosa, a esposa devotada e a mãe criadeira) conhece uma forte expansão e um crescente sucesso popular, até alcançar a admiração dos imperadores romanos (como Calígula, que mandou construir em Roma um templo de Ísis) e tornar-se mesmo uma entidade filosófico-mística entre os gnósticos. A propósito das abstinências e confissões nesses ritos (cf. Cumont, F. Les Religions orientales dans le paganisme romain. Paris: E. Leroux, 1929, pp. $36-7$ e 218; e Turcan, R. Les Cultes orientaux dans le monde romain. Paris: Les Belles Lettres, 1989, p. 113) (devo essas referências a Paul Veyne) (FOUCAULT, 2006a, p. 141).
} 
aristocrática dos grupos platônicos e aristotélicos -, que acarretavam, por mais populares que fossem, uma reflexão teórica e filosófica doutrinal importante. O que não quer dizer que o círculo epicurista tenha se restringido apenas a esse formato. $\mathrm{Na}$ Itália, especificamente em Nápoles, formaram-se grupos bem sofisticados e eruditos.

\section{8 $O$ aspecto da utilidade da amizade}

No nosso mundo, completamente marcado pela moral cristã, as maneiras pelas quais nos permitimos nos relacionar conosco mesmos e uns com os outros encontam-se pautadas nas bases morais do cristianismo. Tinha-se um olhar comum no sentido de que estar vivo estava intrinsecamente relacionado à ideia de estar sempre buscando se manter salvo. Ou seja, não se separava vida e salvação, como acontece bem claramente a partir do cristianismo. O tema da salvação se transformaria, mas, sempre, boa parte dessa preocupação se voltava para a vida, para o governo de si mesmo, donde cada um buscava aquilo que o perturbava e o incomodava configurando os vícios. A salvação de si consistia em uma luta para se liberar desses vícios e tal conquista poderia ser obtida a partir de uma aplicação a si mesmo:

Lembremos que, para Platão, era a salvação da cidade que envolvia, a título de consequência, a salvação do indivíduo. $\mathrm{Ou}$, para falar um pouco mais precisamente - ainda que sempre de um modo muito global e esquemático , em Platão havia que ocupar-se consigo porque era preciso ocupar-se com os outros. E, ao salvar os outros, simultaneamente se salvava a si. Pois bem, parece-me que agora a relação é inversa: é preciso ocupar-se de si porque se é si mesmo e simplesmente para si. Quanto ao benefício para os outros, a salvação dos outros, ou a maneira de nos ocuparmos dos outros possibilitando sua salvação ou ajudando-os na sua própria salvação, virá a título de benefício suplementar ou, se quisermos, decorrerá a título de efeito - efeito necessário, sem dúvida, mas tão-somente conexo - do cuidado que devemos ter conosco mesmos, da vontade e da aplicação que dedicamos à nossa própria salvação (FOUCAULT, 2006a, p. 237).

Mediante o esforço que se exerce sobre si mesmo para se manter salvo, obtém-se, como uma gratificação adicional, a salvação dos outros. Foucault verifica essa inversão da relação em várias situações, como, por exemplo, na concepção epicurista da amizade e na concepção estoica. A concepção epicurista da amizade traz alguns problemas que apontam para a nossa moral no que diz respeito a dois 
aspectos: o fato de Epicuro exaltar a amizade e, também, em textos importantes, a relação que Epicuro faz entre a amizade e a utilidade. Hoje, temos uma concepção de amor desvinculada dos interesses concretos de existência, por exemplo. $\mathrm{Na}$ Antiguidade, deparamos com um jogo mais concreto no campo das amizades, em que a ideia de utilidade da amizade não era considerada algo que diminuísse a qualidade da amizade. Ao contrário, era considerada componente dela e, portanto, recebia atenção, no sentido de ser elaborada, entre outras coisas. Foucault cita a célebre Sentença Vaticana 23: “Toda amizade é por ela própria desejável; entretanto, ela tem seu começo na utilidade". ${ }^{27}$ Foucault observa o problema do utilitarismo no epicurismo e diz que "a amizade epicurista é uma forma do cuidado de si, mas, ao mesmo tempo, esse cuidado de si não é por isso a preocupação com a utilidade". Assim, Foucault mostra que não são opostos o fato de, ao mesmo tempo, ser desejável e ter o seu começo na utilidade, como se quanto mais útil menos desejável fosse. Ou, além disso, o papel de um descartaria o papel do outro na amizade. Segundo Foucault:

Creio que não é muito difícil interpretar esse texto e o que ele quer dizer. A utilidade é a ophéleia, isto é, alguma coisa que designa uma relação externa entre o que se faz e por que se o faz. A amizade é útil. É útil porque pode me ajudar, por exemplo, se tenho dívidas e quero ser ajudado financeiramente. Pode ser útil na carreira política, etc. É bem assim, diz Epicuro, que a amizade começa. Ou seja, ela de fato se inscreve no regime das trocas sociais e dos serviços que vinculam os homens (FOUCAULT, 2006a, p. 238; grifo meu).

No entanto, se a amizade é inaugurada dessa forma, diz Foucault, ela é ao mesmo tempo "hairetè di' heautén", o que quer dizer que deve ser decidida a partir dela mesma. Segundo Foucault, essa ideia encontra seus alicerces na Sentença Vaticana 39, que afirma que "nem é amigo quem busca sempre a utilidade, nem quem nunca a associa à amizade; pois o primeiro faz com o benefício o tráfico do que se dá em troca, o outro rompe com a boa esperança para o futuro" (FOUCAULT, 2006a, p. 238). O que Foucault está ressaltando aqui é a busca de um equilíbrio entre o desejo de amizade e a utilidade que a pode inaugurar, que não se exclua a utilidade como se ela corrompesse a amizade, como pode parecer para

\footnotetext{
${ }^{27}$ Nota de Foucault: As Sentence Vaticane são assim denominadas por terem sido descobertas em um manuscrito do Vaticano que compreendia uma compilação de 81 sentenças de caráter ético. Quanto às Máximas Capitais, reagrupam um conjunto de enunciados decisivos que pode ter sido constituído, ao mesnos inicialmente, pelo próprio Epicuro (FOUCAULT, 2006a, p. 237).
} 
nós, hoje. Finalmente, do ponto de vista epicurista, a amizade só é desejável se conservar um componente útil. Seguindo o itinerário de Foucault, cito ainda a Sentença Vaticana 34: "Da ajuda por parte dos amigos, recebemos não tanto a ajuda que deles nos vem, quanto a confiança nessa ajuda" (FOUCAULT, 2006a, p. 239). Aqui é importante frisar que a amizade faz parte da felicidade (makariótes) e que ela se traduz em independência no tocante aos males que podem derivar do mundo:

Essa independência em relação aos males nos é assegurada por várias coisas, entre elas a seguinte: da existência dos nossos amigos recebemos não tanto uma ajuda real quanto a certeza e a confiança de podermos receber essa ajuda. Nesse momento, a consciência da amizade, saber que estamos rodeados de amigos e que esses amigos terão para conosco a atitude de reciprocidade correspondente à amizade que lhes dedicamos, é isso que constitui para nós uma das garantias de felicidade. A sabedoria se cerca de amigos na medida em que, tendo a sabedoria por objetivo estabelecer a alma em um estado de makariótes (FOUCAULT, 2006a, p. 239).

O estado de felicidade decorrente da confiança derivada da amizade produz um estado de ataraxia, ou seja, de ausência de perturbação. A amizade aqui seria uma espécie de busca de si mesmo, da própria felicidade, sendo assim considerada uma das formas que se verificam no cuidado de si. Fazer amigos, portanto, é parte do cuidado de si. Assim, a amizade inclui a utilidade e a mantém em um certo estado vivo de equilíbrio, o que possibilita que se possa usufruir de uma certa confiança por parte dos amigos em nós, caracterizando uma capacidade de reciprocidade. $\mathrm{O}$ vínculo complexo entre utilidade e desejabilidade, entre a reciprocidade da amizade e a singularidade da felicidade e da tranquilidade, todo esse conjunto de comportamentos delineia a amizade como parte da sabedoria e da felicidade, configurando-a, ainda, na prática do cuidado de si. Para Foucault:

A utilidade que obtemos de nossas amizades e, consequentemente, a utilidade que nossos amigos obtêm da que lhes dedicamos, são um excedente no interior dessa busca da amizade para si mesmo. Vemos a localização da relação de reciprocidade (utilidade de nós mesmos para com os outros e dos outros para conosco) no interior do objetivo geral da salvação de si e do cuidado de si. É, por assim dizer, a figura inversa da reciprocidade platônica de que lhes falei há pouco, na medida em que, para Platão, devemos nos ocupar conosco para os outros, e são os outros que, na comunidade formada pela cidade, nos asseguram nossa própria salvação. Agora, a amizade epicurista permanece no interior desse cuidado de si e inclui, como garantia 
da ataraxia e da felicidade, a necessária reciprocidade das amizades (FOUCAULT, 2006a, p. 240).

O contorno que Foucault dá ao cuidado de si, modificando as relações entre a salvação de si e a salvação dos outros, parte então da amizade epicurista, que prioriza o si mesmo, dando maior valor à amizade - a entrada do outro no plano de uma multiplicidade. Uma segunda indicação é traçada a partir do ponto de vista estoico do homem como ser comunitário. Por exemplo, em Epicteto, o cuidado de si e o cuidado dos outros se produz a partir da divisão em dois níveis: o natural e o reflexivo. A concepção natural se relaciona com a providência. Para Epicteto, o mundo tem uma ordem na qual todos os seres vivos procuram se manter no melhor estado possível. É como se, naturalmente, uma ordem se estabelecesse entre todos os seres vivos, que, ao buscarem seu próprio bem, acarretariam o bem do outro. A tese de Epicteto seria de que "Zeus dispôs a natureza do animal racional de tal modo que ela não possa obter qualquer bem particular sem acarretar a utilidade comum. Assim, não é antissocial (akoinóneton) fazer tudo para si mesmo (pánta hautô̂ héneka poieîn)" (FOUCAULT, 2006a, p. 241). Essa ideia de fazer tudo para si mesmo, afirma Foucault, não denota um grau de insociabilidade, na concepção de Epicteto. Para ele, o vínculo natural da busca de acordo com os interesses de cada um se integrava com aquilo que poderia ser útil para os outros. Trata-se de uma perspectiva não moralista em relação ao caráter de utilidade da amizade, que, assim, se tornaria mais frutífera. Esse tipo de vínculo caberia também ao ser racional propriamente dito, e ao ser humano, que porta o traço reflexivo. Os animais seriam favorecidos por algumas vantagens que os liberariam de se ocuparem consigo mesmos, como, por exemplo, em relação à pelagem. Os animais não precisam tecer suas vestimentas, ao contrário de nós. Assim, para que possamos viabilizar nossa natureza de ser racional, destacando-nos dos animais, precisamos nos tomar como objeto do nosso cuidado, diferenciando-nos incessantemente do que não somos, mantendo sempre viva a interrogação sobre o que somos nós, sobre o que depende de nós e o que não depende de nós. É importante se orientar a partir das categorias dos kathékonta ou dos proegoúmena. Isso posto, seja qual for a representação que se apresente, aquele que tiver se ocupado consigo próprio, discernindo o que depende e o que não depende dele, carregará consigo recursos que possibilitam que ele cumpra o papel de membro da comunidade humana da qual faz parte. Foucault 
destaca um trecho do $11^{\circ}$ colóquio que ilustra essa relação entre cuidado de si e cuidado do outro:

O exemplo é bem concreto. É a história de um pai de família que tem atribulações porque a filha está doente. Quando ela ficou gravemente doente, ele partiu às pressas e abandonou a cabeceira da filha e a casa, deixando-a assim aos cuidados dos outros, isto é, das mulheres, dos domésticos etc. Por que fez isso? Por egoísmo? De modo algum. Pelo contrário, fez isso porque amava a sua filha. E a amava tanto que, em sua afeição, sentiu-se perturbado pela doença da filha e foi por cuidado com ela que abandonou a criança doente aos cuidados dos outros (FOUCAULT, 2006a, pp. 242, grifo).

\section{A perspectiva de Epicteto é a da ordem natural das coisas, ${ }^{28}$ por isso ele critica} a conduta desse pai e valoriza o amor da família como elemento natural, o amor da família é considerado por ele algo natural. E, se esse amor é natural, ele deve seguir os princípios que regem as ligações familiares. Epicteto diz que, se todos aqueles que ficaram ao lado da criança a tivessem abandonado também, ela teria morrido. E, assim, Epicteto afirma que esse pai cometeu um erro:

Em suma, diz Epicteto, cometeste um erro. O erro que cometeste consiste em que, no lugar de considerar que tuas relações com tua filha estavam inscritas e prescritas na natureza - no lugar, portanto, de te conduzires em função desse imperativo, que te fora ditado pela natureza e por tua razão de indivíduo natural e animal racional -, só te ocupaste com tua filha, só nela pensaste, e tu te deixaste de tal modo comover por tua doença que, perturbado por ela, não suportando ver aquela cena, partiste. Cometeste um erro, erro que consiste em teres esquecido de cuidar de ti para cuidar de tua filha (FOUCAULT, 2006a, p. 243).

Epicteto vai afirmar a importância vital do cuidado de si, mostrando que, se esse pai tivesse cuidado de si mesmo, se tivesse se considerado como um ser

\footnotetext{
${ }^{28}$ Para Foucault, a noção de "natureza humana" e o termo "natural" são alvo de uma análise crítica a partir dos problemas encontrados, por exemplo, nas pesquisas de categorias como "normal" e "anormal". Estivemos atentos no decorrer da escrita desta tese ao uso dos termos "natureza humana", "natureza" ou "natural" quando lançamos mão de citações extraídas do livro $A$ hermenêutica do sujeito. Foucault cita trechos de pensadores antigos dos séculos I e II da nossa era que decreviam suas questões em relação ao campo da subjetivação usando essas categorias. Estamos seguindo seu itinerário atentos sempre para, ao pinçar esses termos dos antigos, não dispensar toda a problematização relacionada à invenção do conceito de normalidade relacionada a outra categoria bem problemática, que é a de natureza humana, realizada na primeira etapa de sua obra - período da arqueologia e genealogia - e para os graves problemas que os usos desses termos acarretam no nosso mundo. Estamos circunscrevendo tais noções dentro do uso de cada período recortado, entendendo que o que eles denominavam como natureza humana naquele mundo tem diferenças significativas em relação aos sentidos conferidos hoje.
} 
racional, examinando as representações que chegassem ao seu espírito sobre a doença da filha, se tivesse sondado a si próprio, sobre quem ele é, quem é a filha, a natureza e o fundamento dos laços que os unem, à vista disso não teria se deixado perturbar pela paixão e pela afeição em relação à fillha. Essas precauções visam a uma atitude ativa diante das representações que tomaram conta dele, possibilitando um gesto de escolha de atitude. Para Epicteto, faz-se necessário se tornar skholastikós por meio de uma prática de si consigo mesmo, de exame rigoroso das próprias opiniões. Esse exemplo esclarece que o cuidado do outro pode acabar causando danos, já que o que parece ser da ordem do egoísmo daria lugar, na verdade, a uma atitude ativa diante da situação de abalo que o faria se manter ao lado da filha, cuidando dela como the cabe como pai.

Com esse exemplo bem concreto, vemos como o cuidado de si é que, por ele mesmo e a título de consequência, deve produzir, induzir as condutas pelas quais poderemos efetivamente cuidar dos outros. Comecemos, porém, por cuidar dos outros e tudo estará perdido (FOUCAULT, 2006a, p. 244).

Para Marco Aurélio, o cuidado de si, mesmo no caso do príncipe, homem eminentemente político - indivíduo que, no mundo romano, supostamente deveria priorizar o cuidado dos outros sobre o cuidado de si -, deveria partir do cuidado de si, ao contrário do que se passava na pólis grega, conforme estabelecido no Alcibíades de Platão, em que o cuidado de si devia ser norteado apenas pelo cuidado oferecido aos outros. Foucault discorre especificamente sobre Marco Aurélio pelo fato de ele ter exercido a função de príncipe e escrito sobre sua experiência, sempre dando primazia à ocupação consigo próprio, mesmo num cargo voltado principalmente para a ocupação com os outros. Por exemplo, no texto intitulado Pensamentos, de Marco Aurélio, quase não deparamos com alusões ao exercício do poder imperial. Há uma longa passagem sobre o modo conveniente de acolher os outros no que se refere à atividade imperial, em que se colocam questões relativas ao cotidiano, tal como o modo de receber os outros, de se dirigir ao subordinado, de se relacionar com aqueles que lhe dirigem solicitações, e assim por diante. Marco Aurélio trata a questão do príncipe não pela via de invocar as incumbências exclusivas a essa função, mas descreve regras gerais de conduta pertinentes a todos.

De acordo com Foucault: 
O princípio geral de conduta, para quem quer ser príncipe como o quer Marco Aurélio, consiste precisamente em eliminar de seu comportamento tudo o que possa referir-se à especificidade de uma tarefa principesca, à especificidade de certas funções, privilégios ou mesmo deveres. É preciso esquecer que se é um César, e somente realizar o trabalho, cumprir os encargos cesarianos sob a condição de comportar-se como um homem qualquer: "Acautela-te de te cesarizares profundamente e de te impregnares desse espírito. Conserva-te, pois, simples, honesto, puro, grave, natural, amigo da justiça, piedoso, benevolente, afetuoso, firme no cumprimento dos deveres" (FOUCAULT, 2006a, p. 245).

Nos estoicos, o Império, o Principado configura um ofício e uma profissão, já que o foco não é o fato de se ser imperador, e sim o de se ser si mesmo em primeiro lugar, da mesma forma que qualquer um que tenha que exercer sua profissão. A preocupação consigo promove uma espécie de regulação no que diz respeito às ocupações próprias à tarefa de imperador. Foucault mostra que o que se torna imperativo aqui é o cumprimento de tarefas que fazem parte do conjunto mais amplo que é ele mesmo por ele mesmo. No livro VIII, mostra Foucault, Marco Aurélio diz que é fundamental se manter focado em seu próprio labor, buscando ser um homem de bem, cumprindo as exigências características à natureza do homem, sem hesitar. Foucault destaca alguns elementos desse texto que, segundo ele, são bem importantes. Primeiro, no que diz respeito a se manter fixado no labor, se precavendo de tomar o Império ou a soberania como privilégio, como status, e sim mantendo-a no plano de uma tarefa como qualquer outra. O segundo ponto, que poderia dar um ar de ambiguidade em relação à posição de imperador, diz respeito ao seu caráter de exclusividade. Diferente de todos os outros ofícios, trabalhos e profissões, somente um pode se encarregar do Império, mas deve-se simplesmente cumprir sua função, atentando para as particularidades inerentes ao Principado. E, por último, essa tarefa deve se ancorar no princípio moral de que se deve sempre ser um "homem de bem", atendendo àquilo que a natureza requer de cada um:

A honestidade moral, que, no caso do imperador, não é definida pela tarefa específica ou pelos privilégios que lhes são próprios, mas pela natureza - uma natureza humana que ele partilha com qualquer um -, é isso que deve constituir o próprio fundamento da sua conduta de imperador e, consequentemente, definir a maneira pela qual ele se ocupa com os outros. Deve fazê-lo sem olhar para trás, e aqui reencontramos aquela imagem sobre a qual muitas vezes retornaremos, a saber, que o homem moralmente bom é aquele que, uma vez por todas em sua vida, fixou para si um objetivo do qual não deve, de modo algum, desviar-se: não deve lançar seu olhar nem para a 
direita nem para a esquerda, nem para o comportamento dos homens, nem para as ciências inúteis, nem para todo um saber do mundo que para ele é sem importância; tampouco deve olhar para trás a fim de procurar atrás de si os fundamentos de sua ação. Os fundamentos de sua ação é que constituem seu objetivo. E qual o seu objetivo? É ele próprio (FOUCAULT, 2006a, p. 248).

Em conclusão, o cuidado de si, o exercício constante de voltar-se para si mesmo por parte do imperador pretende não somente seu próprio bem, como desenha, um raio de alcance que extrapola o si mesmo e que acaba inevitavelmente atingindo o outro.

\subsection{0 sujeito e a verdade: o olhar voltado para si}

Foucault afirma que a relação entre o dizer verdadeiro e a prática do sujeito, ou seja, o nexo entre o dizer verdadeiro e o governo de si e dos outros, sempre esteve no cerne de suas pesquisas, tendo sido abordada sob as mais variadas formas: pela loucura e pela doença mental, pelas prisões e pela delinquência e, finalmente, pela sexualidade. No que se convencionou chamar de período da ética, fase final de sua obra, Foucault relaciona mais uma vez o dizer verdadeiro e o governo do sujeito, dessa vez no pensamento antigo, especificamente no período anterior ao cristianismo. Ele engendra a questão sob a forma e o panorama da constituição de uma relação de si para consigo, com o propósito de delinear um modo particular de experiência de si que perpassa a experiência ocidental do sujeito por ele mesmo, ao mesmo tempo em que também percorre a experiência ocidental do que o sujeito pode ter ou fazer em relação ao outros:

Esta, pois, a questão que, de modo geral, quero abordar. É a questão do vínculo entre o saber das coisas e o retorno a si que vemos aparecer em certos textos da época helenística e romana dos quais gostaria de tratar, questão em torno daquele antigo tema que Sócrates já evocava no Fedro, ao perguntar se devemos escolher o conhecimento das árvores ou o conhecimento dos homens. E ele escolhia o conhecimento dos homens. É um tema que encontraremos a seguir, entre os socráticos, quando dizem, uns após outros, que o interessante, importante e decisivo não é conhecer os segredos do mundo e da natureza, mas conhecer o próprio homem. É um tema que encontraremos também nas grandes escolas filosóficas cínicas, epicuristas, estoicas e é quanto a elas que, na medida que dispomos de textos mais numerosos e mais explícitos, tentarei examinar como o problema está posto e de que modo é definido (FOUCAULT, 2006a, p. 282). 
O que se pode verificar pelo que sabemos da experiência dos cínicos relativa a esse período é que a posição do movimento cínico, no que diz respeito à questão da relação entre conhecimento da natureza e conhecimento de si, e que também diz respeito à ideia de retorno a si e de conversão a si, é bem complexa. O que chegou até nós é a ideia de uma recusa por parte dos cínicos a respeito do que, para eles, era o saber do mundo, sua concepção de natureza. Quando, no entanto, Diógenes Laércio escreve $A$ vida de Diógenes, deparamos com a descrição de um período em que Diógenes foi nomeado preceptor do filho de Xeníades, ao qual dedicou a transmissão de uma educação rica, voltada para as ciências. Foucault recorta, nesse contexto do início do Império um texto de Demetrius, filósofo cínico aclimatado a Roma e ao meio aristocrático, citado por Sêneca no livro VII do De beneficiis, para apresentar a prática filosófica de confidente. Demetrius foi solicitado como confidente de Thrasea Paetus, quando este estava nos seus últimos momentos, para travar um diálogo sobre a imortalidade da alma, de maneira socrática, sendo acometido pela morte quando estava à parte com Demetrius, dialogando. Esse exemplo apresenta um cínico bem instruído e ambientado, referenciado por Sêneca nos diversos momentos em que foi por ele citado.

Nessa mesma passagem, Sêneca declara que Demetrius recomendava o modelo do atleta como recurso, ou seja, era importante se espelhar nesse modelo e tentar ser um bom atleta. A ideia não é conhecer toda uma gama de gestos, mas, ao contrário, poder se manter treinado e firme naqueles gestos necessários para a luta. Para eles, era fundamental exercitar reiteradamente esses gestos, de forma que se tornassem familiares, a ponto de sempre se estar apto para o seu uso. O tema do atleta vai aparecer constantemente entre os cínicos. Foucault destaca um trecho do texto de Sêneca para melhor ilustrar essa ideia:

O grande lutador não é, diz ele, quem conhece a fundo todas as figuras e todas as posições pouco usadas na arena, mas quem conscientemente treinou-se bem em uma ou duas dentre elas e explora autenticamente o seu emprego, pois não importa a quantidade de coisas que sabe se não souber bastante para vencer; assim, no estudo que nos ocupa, muitas são as noções fúteis, poucas as decisivas (FOUCAULT, 2006a, p. 283).

O critério estabelecido aqui é o da utilidade, que diz respeito aos conhecimentos que realmente podem ser utilizados na vida em sua dimensão concreta de luta, pois, se estamos falando de vida, estamos necessariamente falando 
de luta. Não se trata aqui de uma mera divisão entre o conhecimento do mundo e da natureza e o conhecimento do homem, como se o crivo que verifica a utilidade ou não dos conhecimentos fosse estabelecido por essa perspectiva. Vale ressaltar a importância que Foucault observa nessa análise dos cínicos, da vida como acontecimento, no caso. Não se trata de não estar atento ao conhecimento do mundo, mas de se estar sempre voltado para o modo de existência diante desses acontecimentos, manter-se posicionado na vida, sem se vitimizar frente aos mistérios e às forças da natureza. Isso funcionaria como um cuidado com o psiquismo, se pensarmos, por exemplo, na nossa condição até hoje. O trecho que Foucault recorta de Sêneca esclarece essa ideia:

Tu podes ignorar a causa que faz erguer o oceano e reconduzi-lo ao seu leito, podes ignorar por que a cada sete anos um novo caráter se imprime na vida do homem [ideia de que a cada sete anos iniciamos uma nova fase da existência, um novo modo de vida]; por que, vista de longe, a largura de um pórtico não conserva suas proporções, as extremidades se aproximando e se estreitando, as colunas se tocando nos últimos intervalos; por que os gêmeos, separados na concepção, são reunidos no parto, se uma concepção se divide em dois seres, ou se houve uma dupla concepção; por que, nascidos ao mesmo tempo, o destino dos gêmeos é tão diverso; por que os acontecimentos estabelecem tão grandes distâncias entre eles, quando tanta proximidade houve em seu nascimento. Nada perderás negligenciano coisas cujo conhecimento nos é interditado e inútil. A obscura verdade se oculta em um abismo. E não podemos acusar a malevolência da natureza. Porquanto nela nada é difícil de descobrir senão as coisas cuja descoberta só tem por fruto a própria natureza. Tudo o que nos pode fazer melhores ou felizes, ela pôs sob nossos olhos e ao nosso alcance (FOUCAULT, 2006a, pp. 284-5).

Não pretendemos comparar nossa época com a Antiguidade e desqualificar todos os avanços conquistados no campo da ciência. A questão que se pretende colocar aqui diz respeito ao modo pelo qual o sujeito se instaurou diante dos acontecimentos que, no nosso mundo, dizem repeito à ideia de progresso dos saberes e a implicação disso na vida das pessoas. Dedicaremos um capítulo a esse assunto posteriormente. Por ora, vale ressaltar o destaque que Foucault dá à elaboração de Sêneca sobre o que importa ou não conhecer, e sobre como se posicionar ante as limitações próprias ao ato de conhecer. Sêneca afirma que, quando nos tornamos mais fortes frente aos acasos e nos elevamos acima do temor, nos tornamos capazes de nos redimensionarmos, buscando riquezas para nós mesmos, em vez de nos voltarmos para o infinito, o que seria investir em uma tarefa 
impossível de se realizar. Para Sêneca, quando delineou pensamentos a respeito do temor a Deus e aos outros, e procurou manter uma certa estabilidade em relação a esse terror, passando a se ver sempre como um animal social nascido para viver em comunidade, o ser humano se comprometeu a se trabalhar como esse animal social, entendendo a si mesmo a partir dessa necessidade e dessa limitação. A nosso ver, Sêneca elabora aqui uma questão ética, pois, ao situar o homem como um animal que se organizou a partir da união de forças que o levou à aquisição de riquezas para sua manutenção enquanto espécie, aponta para o fato de que o que nós somos, aquilo que pudemos alcançar, é inerente, ao mesmo tempo, a nossa condição de animal social. Assim, Sêneca propõe a reflexão sobre essa condição, já que, se a vida existe em sociedade, tal relação não deve ser menosprezada, no sentido de ser naturalizada e, portanto, pouco refletida. Para Sêneca, é fundamental refletir sobre as condições concretas da existência, estando sempre alerta para lutar em busca de não se deixar levar pelas frivolidades do mundo, já que estas acabam servindo para ornamentar a vida sob o alto preço do tormento. Em relação à morte, ao fato de se ter obtido a compreensão de que ela não produz males, mas, ao contrário, acaba com eles, a alma deve se dedicar à virtude e acreditar que o mundo pertence a todos, buscando manter-se firme ao passar pelos abalos advindos da vida, buscando adquirir o máximo possível de conhecimento útil para a vida. Diz Sêneca: “o resto não passa de futilidades do lazer" (FOUCAULT, 2006a, p. 285). ${ }^{29}$

Foucault assinala então que Sêneca elenca tanto o que seria útil quanto o que seria inútil conhecer, afirmando que, dentro do que seria inútil, teríamos "a causa dos maremotos, a causa do ritmo dos sete anos que cadenciariam a vida humana, a causa das ilusões de ótica, o motivo de haver gêmeos e o paradoxo de duas

\footnotetext{
${ }^{29}$ Lembramos de $O$ mal-estar da civilização, em que Freud afirma que os indivíduos só podem se manter ligados uns aos outros como uma comunidade humana mediante a repressão de parte das exigências instintuais: "A vida humana em comum se torna possível apenas quando há uma maioria que é mais forte que qualquer indivíduo e se conserva diante de qualquer indivíduo. Então o poder dessa comunidade se estabelece como "Direito", em oposição ao poder do indivíduo, condenado como "força bruta". Tal substituição do poder do indivíduo pelo da comunidade é o passo cultural decisivo. Sua essência está em que os membros dessa comunidade se limitam quanto às possibilidades de gratificação, ao passo que o indivíduo não conhecia tal limite. Portanto, a exigência cultural seguinte é a da justiça, isto é, a garantia de que a ordem legal que uma vez se colocou não será violada em prol de um indivíduo. Não é julgado, aqui, o valor ético desse direito. O curso posterior da evolução cultural tende a tornar esse direito não mais a expressão da vontade de uma pequena comunidade - casta, camada da população, tribo -, que novamente age como um indivíduo violento face a outros grupos, talvez mais numerosos, desse tipo. O resultado final deve ser um direito para o qual todos - ao menos todos os capazes de viver em comunidade - contribuem com sacrifício de seus instintos, e que não permite - de novo com a mesma exceção - que ninguém se torne vítima da força bruta" (FREUD, 2010, pp. 56-7).
} 
existências diferentes e nascidas sob o mesmo signo etc." (FOUCAULT, 2006a, p. 285).

Para Foucault, um aspecto perpassa todas essas experiências: problemas ligados à saúde, ao modo de vida, ao ritmo dos sete anos que dizem respeito à dimensão concreta da existência. Assim, o que definiria o caráter de inutilidade do conhecimento não viria pelo critério de tangenciar ou não a vida humana. O que demarca a inutilidade do conhecimento é o fato de ser circunscrito pelas causas. Demetrius entende que essas causas têm sua importância em certa medida, mas não devem ser colocadas como o foco principal do conhecimento. Se a natureza ocultou tais causas, ela está mostrando, ao mesmo tempo, que não é útil conhecer a causa dessas coisas. E Sêneca afirma ainda que, se a alma estiver retirada ao abrigo, não tem importância se distrair com essas especulações, que se prestam a ornamentar o espírito, mais do que o fortalecer. Foucault associa essa ideia à ideia central do texto, que diz que essas descobertas têm como resultado principal a descoberta pela descoberta:

Essas causas estão ocultas. Estão ocultas porque é inútil conhecê-las. É inútil conhecê-las não porque proibido, mas porque, se as quisermos conhecer, ao conhecê-las não obteremos mais do que algo suplementar, quando a alma, estando in tutum retracto (retirada na região de segurança que lhe fornece a sabedoria), quererá a mais, a título de distração e para sentir um prazer que reside, precisa e unicamente, na própria descoberta, buscar essas causas. Prazer de cultura, por consequência, prazer suplementar, prazer inútil e ornamental: é isso o que a natureza nos sinalizou ao nos mostrar que todas essas coisas que, repito, nos tocam em nossa própria existência não estão para serem investigadas, para serem pesquisadas no plano da causa. É o conhecimento pela causa como conhecimento de cultura, como conhecimento ornamental que assim está denunciado, criticado, rejeitado por Demetrius (FOUCAULT, 2006a, pp. 286-7).

O tipo de conhecimento aqui traçado é totalmente diferente do que vai se estabelecer no cristianismo. Para Demetrius, é indispensável regular o conhecimento de si mesmo como demarcação do mundo como um habitat comum a todos, tendo em vista a tarefa de constituir uma comunidade. Vale ressaltar que os conhecimentos de que se trata aqui em nada se aproximam do que será engendrado posteriormente como arcana conscientiae (os segredos da consciência), no sentido de afirmar um conhecimento interior em detrimento do conhecimento sobre o mundo, como, por exemplo, uma espécie de descrição 
profunda das paixões, desejos e enfermidades. Nada disso. Nada que se assemelhe a um exame de consciência. Não há uma tentativa de circunscrever algo como a ideia de natureza humana. Os temas referidos eram aqueles que contornavam a existência humana, ou seja, os deuses, o mundo em geral e o grupo humano. Isso não dizia respeito ao próprio indivíduo, não investe em uma mudança do olhar da natureza para os segredos da consciência. Prioriza-se o olhar para o mundo e um olhar para si e para o outro, ou seja, sobre aquilo que nos cerca. Assim, Demetrius opõe saber inútil a saber relacional, uma modalidade especial de saber que segue uma direção entre nós mesmos e o mundo, considerando os deuses, o Kósmos, o mundo, sempre relacionando cada uma dessas coisas a nós, mantendo vivo o critério de relação:

Fazendo de nós mesmos o termo recorrente e constante de todas essas relações é que deveremos conduzir nosso olhar para as coisas do mundo, para os deuses e para os homens. É nesse campo de relação entre todas as coisas e nós mesmos que o saber poderá e deverá desenvolver-se. Saber relacional: essa me parece ser a primeira característica do conhecimento que é validado por Demetrius (FOUCAULT, 2006a, p. 288).

Posta essa propriedade, da modalidade relacional do saber, Foucault reconhece outro ponto importante de se notar - o caráter prescritivo desses saberes. Saber que não se tem que desenvolver tanto temor na relação de si mesmo com os outros, com os deuses, que não se deve dar valor a ornamentos e frivolidades, dado que tanto atormentam a vida, e que não se deve passar pela vida ocupado em temer a morte, criando o entendimento de que ela, na verdade, não é um mal em si, mas que, ao contrário, é capaz de pôr fim aos males são conhecimentos que, circunscritos como princípios de verdade, fazem o papel de prescrições:

O que aqui está em causa são verdades prescritivas. Portanto, o que há a conhecer são relações: relações do sujeito com tudo o que o cerca. O que há a conhecer, ou mehor, a maneira como se há de conhecer, é tal que o que é dado como verdade seja lido, de saída e imediatamente, como preceito (FOUCAULT, 2006a, pp. 288-9).

Demetrius qualifica esse tipo de conhecimento por sua capacidade de transformar o sujeito. Dado que se formule esse modo de conhecer, se obtém junto a isso, necessariamente, uma transformação do sujeito. Graças a essa conquista, é 
possível se sentir menos impotente diante dos acontecimentos por alcançar uma certa estabilidade consigo mesmo. Esses conhecimentos, assegura Demetrius, tornam o indivíduo beati (bem-aventurados), se opondo ao ornamento da cultura, que pode ser até uma verdade, mas não é suficiente para lograr a transformação do sujeito. Quer dizer, os conhecimentos inúteis não são marcados pelo conteúdo, não têm uma lógica prescritiva, então, não têm eficácia sobre o sujeito, não podem transformá-lo. O efeito se encontra na natureza do sujeito no que diz respeito a sua maneira de agir, a seu êthos. Há uma série de palavras gregas, tanto na forma de substantivos quanto na de verbos e adjetivos, utilizadas em Plutarco e, ainda, em Dionísio de Halicarnasso: ethopoieîn, ethopoiía, ethopoiós. Ethopoieîn designa fazer o êthos, produzir, transformar, modificar o êthos, o modo de existência. É ethopoiós aquilo que pode transformar a maneira de ser de um indivíduo. Então é o caráter etopoético ou não do saber o aspecto principal que diferencia o saber útil do inútil. E essa crítica ao saber inútil não se contrapõe ao saber útil, como se este tivesse um grau acima no sentido de um valor, como se carregasse um conteúdo especial sobre o indivíduo e seu interior, não se trata disso; é apenas uma modalidade especial do mesmo saber das coisas exteriores. O saber delineado nesse plano não se volta de modo algum para um tipo de saber de decifração dos arcanos da consciência, o modelo de exegese de si que vai ser instaurado com o cristianismo. A noção de saber útil em Demetrius está estritamente ligada ao processo de transformação do sujeito.

\subsection{Do cuidado de si à conversão a si}

Foucault monta toda a questão do biopoder em cima do Estado, providência no momento em que o neoliberalismo está sendo estruturado. Para Foucault, esse contexto instaura a exigência de um elemento ético a partir da formação de um campo novo na nossa época - o campo da subjetivação, em que o indivíduo, a partir de um movimento de inflexão do olhar na direção de si mesmo, possa resistir, pelo menos em parte, às demandas vindas do Estado ou das instituições. O que observamos na nossa época, a partir do movimento das minorias, são ações que partem dos indivíduos, tocados pelas mais diversas práticas, delineadas pelas instituições legitimadas para o cuidado da vida das pessoas, baseadas nos direitos humanos etc. Aqueles que rompem com os discursos próprios a sua classe social, 
por exemplo, e engendram outra perspectiva sobre as questões sociais, desmistificando as verdades produzidas pela grande mídia, que se baseia, por sua vez, em saberes preconcebidos, voltados para a manutenção do status quo, se posicionam com um certo distanciamento crítico daquilo que a cultura oferece como verdade pronta. No campo de resistência ao poder estabelecido engendra-se um contrafluxo de afetos que formam coletivos que buscam estabelecer uma reflexão e o combate a graves problemas sociais, como o genocídio dos povos indígenas, os mais diversos massacres racistas e classistas contra os indivíduos jovens e negros das classes mais desfavorecidas, dos moradores das periferias, a homofobia e o feminicídio, por exemplo.

Para Foucault essa resistência contra o poder estabelecido está relacionada ao tema do retorno a si, que na cultura Ocidental aparece com frequência a partir do século XVI, sem que, no entanto, tenha alcançado o nível de organização que obteve na Antiguidade helenística e romana.

Por certo, encontramos no século XVI toda uma ética e estética de si que é, aliás, muito explicitamente referida à que encontramos nos autores gregos $\mathrm{e}$ latinos dos quais lhes falo. Penso que seria necessário reler Montaigne nessa perspectiva, como uma tentativa de reconstituir uma estética e uma ética do eu. Penso também que poderíamos retomar a história do pensamento no século XIX um pouco nessa perspectiva. E então tudo seria, sem dúvida, bem mais complicado, bem mais ambíguo e contraditório. Mas podemos reler toda uma vertente do pensamento do século XIX como a difícil tentativa, ou uma série de tentativas, para reconstituir uma ética e uma estética do eu. Tomemos, por exemplo, Stirner, Schopenhauer, Nietzsche, o dandismo, Baudelaire, a anarquia, o pensamento anarquista etc., e teremos uma série de tentativas, sem dúvida inteiramente diversas umas das outras, mas todas elas, creio eu, mais ou menos polarizadas pela questão: é possível constituir, reconstituir uma estética e uma ética do eu? A que preço e a que condições? Ou então: uma ética e uma estética do eu não deveriam finalmente inverter-se na recusa sistemática do eu (como em Schopenhauer)? (FOUCAULT, 2006a, pp. 3056)

Assim, para Foucault, se nos deparamos hoje com o pensamento e a significação, ou com a completa falta de pensamento ou significação, para expressões que nos são tão familiares, como retornar a si, liberar-se de si, ser si mesmo, ser autêntico etc., estamos diante de uma grave dificuldade no que se refere 
à reconstituição de uma ética do eu, que configura para ele um problema ao qual devemos voltar a nossa atenção:

E é possível que nesses tantos empenhos para reconstituir uma ética do eu, nessa série de esforços mais ou menos estanques, fixados em si mesmos, nesse movimento que hoje nos leva, ao mesmo tempo, a nos referir incessantemente a essa ética do eu, sem, contudo, jamais lhe fornecer qualquer conteúdo, é possível suspeitar que haja uma certa impossibilidade de constituir hoje uma ética do eu, quando talvez seja essa uma tarefa urgente, fundamental, politicamente indispensável, se for verdade que, afinal, não há outro ponto, primeiro e último, de resistência ao poder político senão na relação de si para consigo (FOUCAULT, 2006a, p. 306)

Foucault retoma a noção de cuidado de si antigo descrevendo cuidadosamente as transformações que ela opera, desde quando circunscrito ao Alcibíades, destacando desde sua função exclusivamente pedagógica e política, até o ponto em que acaba se transformando em um princípio bem abrangente. Quando atinge o momento em que se torna uma prática de conversão a si, constituindo dessa forma um eu, Foucault passa a trabalhar essa concepção de conversão a si de maneira que possamos refletir sua transposição para o nosso mundo, abarcando assim a necessidade de situarmos a questão do governo no campo da subjetivação. Ele ressalta a transformação do cuidado de si em conversão a si:

Se considerarmos a questão do poder, do poder político, situando-a na questão mais geral da governamentalidade - entendida a governamentalidade como um campo estratégico de relações de poder, no sentido mais amplo do termo, e não meramente político, entendida, pois, como um campo estratégico de relações de poder no que elas têm de móvel, transformável, reversível -, então a reflexão sobre a noção de governamentalidade, penso eu, não pode deixar de passar, teórica e praticamente, pelo âmbito de um sujeito que seria definido pela relação de si para consigo. Enquanto a teoria do poder político como instituição refere-se ordinariamente a uma concepção jurídica do sujeito de direito, parece-me que a análise da governamentalidade - isto é, a análise do poder como conjunto de relações reversíveis - deve referir-se a uma ética do sujeito definido pela relação de si para consigo. Isso significa muito simplesmente que, no tipo de análise que há algum tempo busco lhes propor, devemos considerar que relações de poder/governamentalidade/governo de si e dos outros/relação de si para consigo compõem uma cadeia, uma trama e que é em torno dessas noções que se pode, a meu ver, articular a questão da política e a questão da ética (FOUCAULT, 2006a, pp. 306-7). 
Essa ideia de constituição de um eu em um movimento de conversão a si se apresenta então como uma possibilidade de conferir forma à existência pela via de um determinado fluxo de resistências, como mencionamos acima. Foucault destaca expressões em latim e em grego que indicam a necessidade de o sujeito se voltar para si mesmo, de se consagrar a si mesmo, que evidenciam dois componentes para melhor compreender essa cultura do eu estabelecida nesse período: eph 'heautòn epistréphein, eis heautòn anakhôreîn, ad se recurrere, ad se redire, in se recedere, se reducere in tutum (retornar a si, voltar a si, fazer retorno sobre si etc.), que apontam sempre para um gesto, um movimento real do sujeito em relação a si mesmo:

Não se trata simplesmente, como na ideia, por assim dizer, "nua" do cuidado de si, de prestar atenção a si mesmo, de dirigir o olhar a si ou de permanecer acordado e vigilante em relação a si mesmo. Trata-se, realmente, de um deslocamento, um certo deslocamento - sobre cuja natureza precisaremos interrogar - do sujeito em relação a si mesmo. O sujeito deve ir em direção a alguma coisa que é ele próprio. Deslocamento, trajetória, esforço, movimento: é o que devemos reter nessa ideia de conversão a si. Em segundo lugar, na ideia de conversão a si temos o tema do retorno, tema também importante, difícil, pouco claro, ambíguo. O que significa retornar a si? Que círculo é esse, que circuito, que dobra é essa que devemos operar relativamente a algo que, contudo, não nos é dado, senão apenas prometido ao termo de nossa vida? Deslocamento e retorno - deslocamento do sujeito em direção a ele mesmo e retorno do sujeito sobre si - são dois elementos que tentaremos elucidar (FOUCAULT, 2006a, p. 302).

O problema da subjetivação é complexo porque se parte de uma certa descrença nas verdades e de uma tomada de posição diante da vida a partir de um distanciamento dos saberes dados, portanto, da aposta em um espaço vazio para uma possível construção pela via dos afetos. O cuidado de si é uma proposta de se conduzir de maneira dinâmica na própria vida, de resistir a nossa tendência em encerrar as coisas em conceitos prontos e acabados, mantendo um espaço aberto, operando um constante deslocamento. Podemos dizer que estamos em um momento em que há urgência em se pensar a subjetivação, já que, a partir dos anos 1980, as máquinas produzem as coisas e o trabalho passa a constituir uma esfera imaterial. Assim, o que temos hoje é gente produzindo gente a partir dos investimentos oriundos do sistema capitalista, que, claro, estão voltados para a manutenção das formas de sociabilidade capitalistas. 
Diante desse circuito perverso, faz-se urgente tomar a subjetivação como um desafio - o de pensar a vida que, por questões de estética e de sensibilidade, quer se transformar a si mesma para se salvar, não repetindo aquilo que mais desgosta e, por isso, desgasta. Foucault faz uma obra como pilotagem nos rastros de sua autobiografia, conduzindo sua vida de modo a se liberar dos dissabores. Tal modo de se conduzir é, ao mesmo tempo, um meio de salvação de si, pois se trata de um cuidado para que o ego e a história não obstruam o fluxo dos prazeres da vida, que circunscrevem a forma do cuidado de si consigo mesmo à possibilidade de uma vida que escape, pelo menos em algum nível, do domínio do poder.

No modelo antigo, era fundamental estar atendo à cilada, colocada para todos pela própria cultura, de não se submeter a uma escravidão ao ego no aspecto do tratamento do ego como imagem pública. Se o sujeito não se liberasse das amarras do ego, se tornaria um escravo, pois não teria a chance de se conduzir em direção a algo propriamente seu, já que se manteria voltado para a obtenção de uma imagem que fosse capaz de satisfazer as demandas oriundas da sociedade (não estamos tratando aqui do ego freudiano nem do ego moderno). Para Sêneca, a história forma um saber distorcido, pois transmite os valores de acordo com os grandes feitos, atribuindo valor ao que vem pelo acaso. Por exemplo, César tem valor porque vem de um maquinário ou porque a sorte o bafeja em algum momento. Desse modelo deriva o modelo do corpo conduzido pela alma, ou seja, pela formação cultural.

\subsection{O abuso do poder e o papel do filósofo no Ocidente}

Foucault não se insere na cena política exatamente como um político, e sim como um questionador, que tem como meta agitar o campo, forjando, a partir desse movimento, problemas que não apareceriam por eles mesmos. Em Política e ética: uma entrevista, ele afirma que não trabalhava colocando questões traçadas previamente, da mesma forma que não tinha em mente realizar determinado projeto político, o que o levou a receber várias críticas, por não ter apresentado nenhuma teoria de conjunto. E, na verdade, esse jamais teria sido o objetivo de seu projeto geral, posto que Foucault entendia as formas de totalização estabelecidas pela política como um recurso muito limitado, preferindo, longe disso, abrir problemas que, nas suas palavras: 
[...] viram a política pelo avesso, atravessam as sociedades em diagonal, e são parte constituinte da nossa história e, ao mesmo tempo, constituídos por ela; assim como o problema das relações razão/loucura, a questão da doença, do crime ou da sexualidade. E seria preciso tentar colocá-los como questões da atualidade e da história, como problemas morais, epistemológicos e políticos (FOUCAULT, 2006b, p. 220).

Foucault engendrou recursos para lidar com esse poder que nos intimida como sujeitos ativos e capazes de transformar as coisas. Aliás, diz Foucault, sobre o poder, não o pensamos simplesmente por uma espécie de obstinação sobre o tema:

Não acredito que nossos sucessores, se refletirem um pouquinho, possam espantar-se por muito tempo com o fato de que, justamente nesse final do século XX, as pessoas de nossa geração tenham colocado, com tanta insistência, a questão do poder. Porque, afinal, se a questão do poder se coloca não é absolutamente porque a tenhamos colocado. Ela se colocou, ela nos foi posta. Ela nos foi posta, é claro, por nossa atualidade, mas também por nosso passado, um passado tão recente que mal parece ter terminado. Primeiramente, o século XX conheceu duas grandes doenças do poder, duas grandes epidemias que levaram até muito longe as manifestações exasperadas do poder. Essas duas grandes epidemias que dominaram o âmago, o centro do século XX, são seguramente o fascismo e o stalinismo. [...] Fenômenos singulares consequentemente, porém é preciso não negar que, em relação $a$ muitos pontos, o fascismo e o stalinismo apenas fizeram prolongar toda uma série de mecanismos que já existiam nos sistemas sociais e políticos do Ocidente (FOUCAULT, 2006b, p. 38; grifo meu).

As análises do poder mostraram que o stalinismo e o fascismo, por exemplo, não se instauram em um vazio, eles se dão sobre uma engrenagem previamente estabelecida pelos aparelhos sociais e políticos do Ocidente. Tanto o formato dos grandes partidos, a expansão dos aparatos policiais, os modelos de repressão, como os campos de trabalho, formam o legado firmado pelas sociedades ocidentais liberais, deflagrando o stalinismo e o fascismo. "Epidemias sociais" como o fascismo e o stalinismo impõem a necessidade de refletir a questão do poder no sentido de que ilustra, sem sombra de dúvida, o problema de que o Ocidente promove articulações políticas, rechaçando, nesse jogo, uma ética. Se o panorama em que se faz política não fecunda suas ações de acordo com uma ética, necessariamente vai produzir as mais perversas formas de conduzir os indivíduos. Segundo Foucault: 
Existem permanentemente virtualidades de qualquer modo estruturais, intrínsecas a nossos sitemas, que podem se revelar à menor oportunidade, tornando permanentemente possíveis essas excrescências do poder dentre as quais os sitemas mussoliniano, hitlerista, stalinista, o atual sistema do Chile e o sistema do Camboja são apenas exemplos, e exemplos incontornáveis (FOUCAULT, 2006b, p. 39).

Para Foucault, o maior problema identificado no século XIX, ao menos no contexto europeu, foi a pobreza e a miséria. O que os pensadores do início do século XIX não cessavam de interrogar era o fato de a produção de riquezas, que teve efeitos inquestionáveis para todo o Ocidente, ter ao mesmo tempo o efeito da pauperização daqueles que a geravam. E o que Foucault constata é que esse problema teria perdido urgência em sua abordagem e que teria se duplicado, não mais pela via da privação das riquezas, e sim pelo descomedimento do poder:

As sociedades ocidentais, de modo geral as sociedades industriais e desenvolvidas do fim desse século, são sociedades atravessadas por essa surda apreensão, ou mesmo por esses movimentos de revolta totalmente explícitos que questionam essa espécie de superprodução do poder que o stalinismo e o fascismo seguramente expressaram de forma nua e monstruosa. Assim, tal como o século XIX precisou de uma economia que tivesse como objetivo específico a produção e a distribuição das riquezas, poderíamos dizer que necessitamos de uma economia que não se baseasse na produção e na distribuição das riquezas, mas nas relações de poder (FOUCAULT, 2006b, p. 39).

A história mostra que a epiméleia heautoû traz consigo uma dimensão ética. Um dos efeitos que podemos pensar em relação ao prevalecimento do gnôthi seautón e da destituição da epiméleia heautoû diz respeito ao esvaziamento de uma preocupação ética mais ampla no campo do conhecimento. O conhecimento, ao se manter sob o domínio dos especialistas, acaba circulando de maneira restrita e de acordo com os interesses do poder - hoje, do capital. E, se a ética relacionada ao domínio do conhecimento é produzida nessa atmosfera, ela fica comprometida com os interesses do capital. Além disso, os segmentos da sociedade que não estão vinculados ao campo científico praticamente não têm contato com os discursos e as práticas provenientes desse campo, tendo algum acesso, no máximo, pela mídia, que noticia as "descobertas" da ciência.

Mas, quando a epiméleia heautoû estava ligada ao gnôthi seautón, a dimensão ética não se distanciava da questão do saber e do poder. Por exemplo, no Ocidente, 
um dos principais papéis do filósofo era estabelecer um limite ao abuso do poder, toda vez que o excesso de poder se tornasse pernicioso. Nesse contexto, o filósofo acabou se fixando no lugar de um antidéspota, o que pode ser verificado em várias posições que ele ocupou. Por exemplo, o filósofo legislador, aquele que definia o sistema das leis, delimitando de que forma o poder deveria ser exercido, que, como mostra Foucault, foi o papel de Solon quando a filosofia grega travou sua separação da poesia, na ocasião em que a prosa grega passava a ser concebida: "Foi certamente aquele em que Solon, em um vocabulário ainda poético, formulou as leis que se tornariam a própria prosa da história grega, da história helênica" (FOUCAULT, 2006b, p. 40). Outro papel do filósofo como antidéspota era o do filósofo pedagogo, como conselheiro do príncipe. Platão, na sua peregrinação ao território de Dênis, o Tirano, se prestava a aconselhar a sabedoria, a virtude, a verdade, e não o abuso de poder por parte do governante.

Esse grupo de filósofos antigos já se dava conta de que a cultura não oferece outra coisa que não as discriminações, o desprezo pelas classes sociais menos favorecidas e o preconceito. Uma existência que se orientasse por uma verdade voltada para si mesmo e para o outro seria delineada ao se trabalhar para inventar os próprios valores, ao mesmo tempo em que seria mantido certo distanciamento dos valores proporcionados pela cultura. A verdade aqui não se aproxima do que o cristianismo estabeleceu sobre a exegese e a confissão. Aqui ela serviria como um princípio regulador que pudesse dar um norte à vida, tanto no sentido individual quanto coletivo. A atitude natural da torção que a cultura do vício produz é que o indivíduo se abstém de si próprio para se entregar à sociabilidade da paidéia. $\mathrm{O}$ cuidado de si é um princípio regulador da atividade, é o que está no cerne da orientação do indivíduo, que passa a submeter tudo a seu crivo. Para elucidar esse pensamento, podemos recorrer a Gros, citando o dossiê "Les autres", de Foucault:

Longe de nos isolar da comunidade humana, aparece, ao contrário, como aquilo que mais exatamente nos articula a ela, já que "a relação privilegiada, fundamental consigo mesmo, deve permitir [ao sujeito] descobrir-se como membro de uma comunidade humana que, dos laços mais estreitos de sangue, estende-se a toda espécie". O sujeito, descoberto no cuidado, é totalmente o contrário de um indivíduo isolado: é um cidadão do mundo. O cuidado de si é, pois, um princípio regulador da atividade, de nossa relação com o mundo e com os outros. Ele constitui a atividade, fornece sua medida e sua forma e, até mesmo, a intensifica (FOUCAULT, 2006a, p. 652; grifo do autor). 
O tema do sujeito, se problematizado, levando em conta a influência do poder econômico, como o das forças imperialistas, na formação do campo subjetivo da nossa época, pode abrir um caminho para realizar o que Foucault denominou “diagnóstico do presente”. E um dos diagnósticos possíveis do nosso mundo é essa busca por um sentido totalizante, que acaba nos impedindo de trabalhar e nos mantém passivos, olhando para aquilo que atribuímos ser o sentido de tudo.

Se fizermos uma breve referência à psicanálise delineada por Lacan, podemos tomar como exemplo sua elaboração da ideia freudiana de falo como significante, no sentido de combater a fixidez, o poder e as idealizações. O falo, para Lacan, é um significante em movimento.

Se nos voltarmos um instante para Nietzsche, lembraremos que, para ele, uma espécie de adiamento da conscientização inevitável da ausência de todo sentido totalizante acabou dando lugar ao ideal ascético. O fato é que, diante do fenômeno da morte de Deus, a nossa civilização aferrou-se a preencher com um sentido moral a imensa lacuna aberta. Hoje, além da força que ainda vigora do sentido moral dado às coisas, vemos se instaurar um outro modo de dar sentido - o da fetichização dos objetos. Esse modo de dar sentido às coisas, que se associa ao conceito de falo, cai como uma luva em um mundo onde impera o poder capitalista.

\subsection{A influência da pastoral cristã na formação do indivíduo moderno}

A objetivação do sujeito no mundo ocidental define a sexualidade a partir de um corte, reduzindo-a basicamente ao sexo como esquema biológico. No nosso mundo, os saberes sobre o sexo são delineados no domínio dos especialistas, visto que essa redução da sexualidade ao corpo acaba circunscrevendo-a como um terreno desconectado da atividade reflexiva. Mas esse esquema tem história: a nossa formação subjetiva sofreu forte influência do cristianismo, resultando na apreensão da nossa sexualidade, principalmente, por um arranjo moral pelo qual, no lugar de uma atividade reflexiva sobre si mesmo, o indivíduo se voltava para si mesmo em busca de cercear os pensamentos indevidos, considerados pecaminosos. Esse arranjo desvincula a atividade reflexiva do sujeito consigo mesmo, instaurando uma prática de exame - atividades inteiramente distintas. Esta última, mais pobre, sem sombra de dúvida. 
Já o exemplo grego de subjetivação não divide o psicológico e o orgânico a partir de uma sexualidade destacada e refletida por um crivo moral. Nesse processo de subjetivação, abarcavam-se os afetos por meio da formação de um campo ético, por meio do domínio das paixões de modo geral, para que o sujeito não fosse dominado por elas. A atividade sexual não tinha o caráter de uma prática pecaminosa. Se a ela se dedicava atenção era porque, por meio dela, o sujeito poderia se perder em suas paixões, se tornando escravo de si mesmo, perdendo a qualidade de temperante. Mas esse perigo dizia respeito também aos outros domínios humanos, não só ao do sexo.

Permitindo-nos um salto para o nosso mundo, especificamente para o século XIX, podemos dizer que, quando Freud inaugura a atividade interpretativa da psicanálise, a partir da fala dos sujeitos que apresentavam sintomas corporais, ele modifica o olhar pelo qual se apreendia a sexualidade até aquele momento, produzindo cortes na "mente" - daí a célebre divisão entre id, ego e superego, donde resta ao superego o tom mais moral, inscrito nessa subjetividade organizada pela pastoral cristã. Desse modo, ele reinscreve, por meio de novos recursos, o terreno da sexualidade em um campo ético. Como vimos no capítulo dedicado à interpretação na Modernidade, Freud, tal como Marx e Nietzsche, nos coloca diante de uma nova possibilidade de interpretações, fundando mais uma vez a possibilidade de uma hermenêutica. Se a interpretação pela via de um "corpo sensível e complexo da concuspicência" tem como efeito o engendramento de um corpo racional e científico, ${ }^{30}$ a subjetivação vem resgatar uma atividade reflexiva do sujeito consigo mesmo, no sentido de uma inflexão do sujeito em direção a si, abrindo um campo em que se distancia dos saberes produzidos pelos especialistas, nos moldes do discurso científico da ciência, pautado no exame, que, por sua vez, está totalmente comprometido pelo modelo de interpretação cristã. Se Foucault designa o curso de 1982 como A hermenêutica do sujeito, considerando a sua crítica ao modelo de uma interioridade do sujeito, podemos supor que ele opera algum resgate do aspecto interpretativo que se distancia completamente do exame, mas que permite um giro do sujeito para si mesmo em um movimento de reflexão sobre seus gestos, suas necessidades, suas questões, enfim. A quebra da moral como o

\footnotetext{
${ }^{30}$ Ideia desenvolvida no subcapítulo intitulado "O corpo científico tem base em uma fisiologia moral da carne".
} 
modelo de verdade que norteia as nossas vidas me parece a chave para a subjetivação.

A psicanálise surge no contato com as paixões das pacientes designadas na época como histéricas. ${ }^{31}$ Quando Freud se desloca da posição de observador das manifestações corporais, que, pelo olhar, atribuía significações, para inaugurar um lugar de escuta de um discurso considerado desarrazoado pela ciência da época, ele aborda os sintomas daquelas mulheres a partir da cultura, inaugurando, assim, um campo ético, já que promove o deslocamento de uma abordagem do sujeito apenas pelo recorte da ciência médica. Desenvolve assim a teoria da repressão e recorta a noção de sujeito do inconsciente, abdicando de um olhar exclusivamente voltado para uma natureza biológia, como marchava a ciência no seu tempo, para dar um estatuto de fala a indivíduos que, naquela organização social, tinham lugares estabelecidos por uma sociedade exclusivamente patriarcal. Segundo Foucault:

A importância histórica de Freud vem, sem dúvida, da impureza mesma de seus conceitos: foi no interior do sistema freudiano que se produziu essa reviravolta da psicologia: foi no decorrer da reflexão freudiana que a análise causal se transformou em gênese das significações, que a evolução cede seu lugar à história, e que o apelo à natureza é substituído pela exigência de analisar o meio cultural (FOUCAULT, 2002a, p. 142).

Mesmo com o advento freudiano do inconsciente, não podemos desprezar a força do modelo da racionalidade tradicional, pautado na racionalidade cartesiana, pois essa é uma linha influente no modelo de pensamento ocidental. O homem moderno e sua ciência se constituem com base no deslocamento de uma posição anteriormente ligada à ideia de Deus, passando a se conduzir por uma atitude de livre-arbítrio, de responsabilidade e autonomia. O indivíduo dito "normal" seria então aquele capaz de tomar suas próprias decisões e de arcar com as responsabilidades advindas de seus posicionamentos. Esse homem dotado de mente e corpo possuiria duas estruturas em pleno funcionamento: uma estrutura orgânica e uma psíquica. A estrutura orgânica funcionaria nos moldes de uma máquina, mas, por ser uma máquina humana, não pode dispensar a estrutura psíquica. Essa divisão

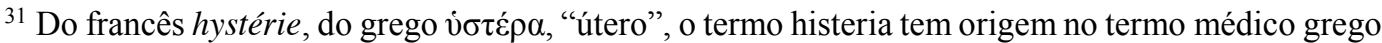
hysterikos, que se referia a uma suposta condição médica peculiar a mulheres, causada por perturbações no útero, hystera em grego. O termo histeria foi utilizado por Hipócrates, que pensava que a causa da histeria fosse um movimento irregular de sangue do útero para o cérebro.
} 
entre corpo e mente tem uma forte carga imaginária - ao mesmo tempo em que se diferenciam, se encontram interligadas.

Se contamos com uma estrutura somática e outra psíquica, e se o psiquismo é formado também por um inconsciente, a estrutura psíquica é formada a partir de uma singularidade ímpar, já que as propriedades subjetivas são próprias a cada ser singular, já que cada um de nós sente, sonha, imagina, delira, pensa, enfim, qualquer propriedade referente à subjetividade é vivida a partir de uma experiência única do próprio indivíduo, uma experiência vivida necessariamente na fronteira entre o indivíduo em jogo e o ambiente. Então não se pode separar o psiquismo do organismo, já que ambos estão imiscuidos, operando simultaneamente. Só há psiquismo se há corpo físico e vice-versa.

Se a influência da cultura sobre nossa formação de sujeito não for refletida, se os saberes produzidos por ela forem simplesmente tomados como verdades, sendo absorvidas como as devidas maneiras pelas quais devem se conduzir, deparamos com uma cultura engendrada pelo poder. Por exemplo, não se problematizam as atitudes referentes ao afeto; elas se educam desde a infância e o que se considera anormal, no nosso mundo, é imediatamente categorizado e medicado. A atividade reflexiva, o exercício do pensamento sobre as nossas atividades mais cotidianas inauguraria, portanto, um campo ético, através do corte do domínio da cultura, que está intimamente ligado ao poder.

O que Foucault vê na organização social dos gregos não caberia na nossa sociedade justamente por este fato: a educação das paixões, que os gregos praticavam em uma relação consigo mesmos, para nós, se afigura um domínio oriundo de verdades externas. Naquele mundo, os gregos tinham a preocupação de dominar suas paixões (enkráteia) (FOUCAULT, 1994, p. 60), pois, como sabemos, eles acreditavam que, se não o fizessem, suas paixões poderiam guiá-los, algo que eles realmente temiam.

Podemos dizer que, hoje, temos uma pedagogia dos afetos de caráter moral. Se tomarmos como base os cursos Os anormais, de 1974-1975, e Segurança, território e população, de 1977-1978, veremos, no primeiro, como o evento da peste, por exemplo, organizou os indivíduos e o espaço de convivência. A partir das ordenações no território e da utilização do exame como instrumento para "cuidar" da vida das pessoas, será inaugurada a categoria de biopoder, ou seja, poder entrelaçado à vida, a vida como o sentido primordial da existência da humanidade. 
Com isso, Foucault mostra que não se pode pensar o indivíduo hoje desprezando o fenômeno da formação das populações. É nosso papel problematizar um campo que, em nome da vida, foi apropriado por um campo de saber-poder, que, como ensina Foucault, não existe separadamente um do outro. Isso posto, no curso de 1978 ele afirma que "a temática do homem deve ser compreendida a partir da emergência da população", porque, em nome da preservação da vida, os afetos foram formatados por esquemas morais que intervieram nos costumes, ditando condições de existência que acabam sendo tomadas como verdades naturais. Como mostra Nietzsche, em A gaia ciência, as paixões e os costumes acabam sendo deixados à parte no que diz respeito ao campo da reflexão (2001, pp. 59-60).

\subsection{A subjetivação como resistência cultural}

Se Foucault não se restringia a forjar seus objetos de pesquisa estritamente no âmbito da filosofia, uma vez que se envolvia com a vida das pessoas, procuramos produzir um material que trate a questão da subjetividade no tocante à dimensão concreta da vida dos indivíduos da nossa época, problemas que indico, já de saída, estarem relacionados a um esvaziamento do campo referente ao plano das subjetividades, no sentido político, dinâmico, do jogo de forças que observamos, por exemplo, nos anos 1960, momento em que Foucault produz suas análises sobre a subjetivação a partir do recorte de um modelo de subjetivação antigo.

Segundo Jaeger, é evidente que a história da personalidade europeia se instala a partir do momento em que os gregos localizaram a questão da individualidade no ápice do desenvolvimento filosófico, no qual Roma e o cristianismo vão operar. É como consequência dessa complexidade que o fenômeno do eu individualizado vai ser desencadeado. Para Jaeger:

Não podemos entender de modo radical e preciso a posição do espírito grego na história da formação dos homens, se tomarmos um ponto de vista moderno. Vale mais partir da constituição rácica do espírito grego. A vivacidade espontânea, a sutil mobilidade, a íntima liberdade (que parecem ter sido as condições do rápido desabrochar daquele povo na inesgotável riqueza de formas que nos surpreende e espanta ao contato com os escritores gregos de todos os tempos, dos mais primitivos aos mais modernos) não têm as suas raízes no cultivo da subjetividade, como atualmente acontece; pertencem à sua natureza. E, quando esse povo atinge a consciência de si próprio, descobre, pelo caminho do espírito, as leis e as normas objetivas cujo 
conhecimento dá ao pensamento e à ação uma segurança antes desconhecida (2013, p. 8).

Para Jaeger, pela perspectiva oriental, não seria possível representar o corpo humano livre e descontraído, tal como fizeram os artistas gregos, simplesmente como uma imitação aleatória de atitudes e movimentos individuais. Os gregos se orientavam pela "intuição das leis que governam a estrutura, o equilíbrio e o movimento do corpo" (2013, p. 8).

Os gregos se diferenciaram dos povos anteriores por se guiarem por uma ideia de legalidade imanente a todas as coisas, o que lhes proporcionava algum conforto. Eles alcançaram a ideia de natureza a partir de sua organização espiritual. Eles tinham ordenado, de antemão, um mundo onde se atribuía às coisas um sentido e um lugar, tudo isso em uma conexão viva em que nada restava. Tal visão de mundo é denominada orgânica, pois qualquer parte tem um lugar no todo. Para Jaeger, a tendência do espírito grego para uma nítida percepção das leis do real, tanto no campo da linguagem, como do pensamento, da ação e da arte, infunde-se nesse entendimento do ser como "estrutura natural, amadurecida, originária e orgânica" (2013, p. 9). Segundo Jaeger:

\begin{abstract}
A palavra alemã Bildung (formação, configuração) é a que designa do modo mais intuitivo a essência da educação no sentido grego e platônico. Contém ao mesmo tempo a configuração artística e plástica, e a imagem, "ideia", ou "tipo" normativo que se descobre na intimidade do artista. Em todo lugar onde essa ideia reaparece mais tarde na História, ela é uma herança dos gregos, e aparece sempre que o espírito humano abandona a ideia de um adestramento em função de fins exteriores e reflete na essência própria da educação (2013, p. 11; grifo meu).
\end{abstract}

Para Jaeger, o fato de os gregos terem se dedicado tão vigorosamente a essa tarefa não é consequência da perspectiva artística, sequer de seu espírito "teórico". Deve-se ao fato de eles terem colocado o homem no centro de seu pensamento. $\mathrm{Na}$ escultura e na pintura, o problema da forma humana; no movimento da filosofia, desde a questão do cosmo até a questão do homem, que atinge seu ponto mais alto em Sócrates, Platão e Aristóteles; na poesia, que, de Homero até os últimos séculos, vai se ocupar do árduo destino do homem; e, por fim, no Estado grego, compreendido somente se considerado pelo prisma da formação do homem e de sua vida como um todo. Segundo Jaeger: 
Tudo são raios de uma única e mesma luz, expressões de um sentimento vital antropocêntrico que não pode ser explicado nem derivado de nenhuma outra coisa e que penetra todas as formas do espírito grego. Assim, entre os povos, o grego é antropoplástico (2013, p. 12).

Esse modelo de subjetivação não cabe exatamente nos moldes do pensamento do nosso mundo, dadas as transformações e evoluções inegáveis que ocorreram na história. Mas o ponto de vista grego, no que se refere à questão do sujeito, articulada à concepção de natureza da época, e à ideia de ordem e forma nas quais se pautavam para refletir a organização social humana, desperta nosso interesse para pensar que o advento do biopoder pode ter como um de seus maiores efeitos hoje a perda de valor estético no que diz respeito à vida em conjunto. No lugar de uma reflexão sobre a vida por algum viés estético, como tanto encantava os gregos, desenhou-se um mundo onde se tem uma comunidade humana que se organiza a partir do medo da morte, que, ao mesmo tempo em que emprega considerável parte de seus esforços para a manutenção da vida, se mantém débil no sentido de fornecer a isso que fica entendido como vida um colorido ético em torno dela e de suas limitações. Se existem forças de resistência ao biopoder irrompendo novos fluxos de afetos na nossa época, é que o biopoder, por ser um modelo de poder, não tem que se resguardar totalmente das forças de resistência - tais forças nos interessam, já que podem se ligar à vida no sentido de uma ética pela vida em suas múltiplas facetas, inclusive a da morte.

\subsection{4 $O$ papel do intelectual na atualidade: o intelectual específico}

Foucault era muito atento ao papel do intelectual, no sentido de seu compromisso ético com a sociedade, de sua atuação voltada para uma problematização sempre a ser relançada, já que não se trataria de conferir soluções aos problemas, mas, ao contrário, de criá-los, abrir crises nas quais nada parece estar acontecendo, fazer aparecer aquilo que não se pode ver por uma perspectiva consensual. Trata-se de uma prática filosófica de engajamento crítico instalada no conjunto social. Foucault era muito sensível ao perigo concernente à posição do intelectual como doutrinador, como modelo daquele que sabe a verdade, que pode ditar o modo certo de pensar, daquilo que se pode ou não fazer. Por isso se designava como "intelectual específico", o pensador que deve pensar os problemas 
singulares de sua época a partir de um distanciamento reflexivo, local e transversal, que não vise dar as direções ou as soluções de determinada questão filosófica (ERIBON, 1996, p. 43). A ideia de intelectual específico decorre do confronto com a ideia de Sartre de intelectual global, universal ou total, pois, para este pensador, o intelectual deveria se elevar como modelo, dizendo quais seriam as boas formas de vida e quais não seriam. Para Foucault, a potência que marca a tarefa do intelectual consiste no fato de ele pensar diferentemente do que se pensa habitualmente e de buscar sempre se diferenciar de si mesmo, se distanciando de si, se transformando. A filosofia foucaultiana se manifesta como modo de vida, um êthos. Todo o seu interesse pelas práticas relacionadas às instituições, diz ele, não foi para "aplicar" ideias, mas para experimentá-las e modificá-las. Em suas palavras:

Acho que é preciso tomar consciência de vários fatos: a pouca ligação "analítica" entre uma concepção fílosófica e a atitude política concreta daquele que a sustenta: as "melhores" teorias não constituem uma proteção eficaz contra escolhas políticas desastrosas; alguns grandes temas, como o "humanismo", podem servir para qualquer coisa, assim como para mostrar com que gratidão Pohlenz teria saudado Hitler. Disso não concluo que seja possível dizer qualquer coisa na ordem da teoria; mas, pelo contrário, que se deve ter uma atitude exigente, prudente, "experimental"; é preciso a cada instante, passo a passo, confrontar o que se pensa e o que se diz com o que se faz e o que se é (FOUCAULT, 2006b, p. 219).

$\mathrm{O}$ intelectual não se prestaria a fornecer as chaves de acesso à verdade. $\mathrm{O}$ seu papel seria o de se instalar na sociedade com o seu ponto de vista crítico, provocando uma certa inquietação nos indivíduos em relação a sua época, despertando-os para a necessidade de exercitar o pensamento crítico, afastando-os das evidências, criando modos singulares de compreensão do nosso mundo. $\mathrm{O}$ fillósofo é aquele que se inscreve no conjunto social produzindo diagnósticos (ERIBON, 1996, p. 128). ${ }^{32}$ Essa atitude em si pode ser vista pelos indivíduos como uma virtude, um gesto de distanciamento do que parece óbvio, como, por exemplo,

\footnotetext{
${ }^{32}$ Eribon destaca uma entrevista de Foucault com Paulo Caruso, em 1969: "É muito possível que aquilo que fiz tenha a ver com a filosofia, principalmente na medida em que, ao menos desde Nietzsche, a filosofia tem como tarefa diagnosticar, e não mais procurar dizer a verdade que possa valer para todos e para todos os tempos. Procuro precisamente diagnosticar, realizar um diagnóstico do presente: dizer o que somos hoje. $O$ trabalho de escavação sob nossos pés caracteriza, a partir de Nietzsche, o pensamento contemporâneo, e nesse sentido posso me declarar filósofo" (ERIBON, 1996, p. 128).
} 
os costumes, a moral, um certo padrão de apreensão das coisas, que constitui nosso modo de ser e de pensar, nossa cultura e nosso tempo:

Mas o que é filosofar hoje em dia - quero dizer, a atividade filosófica - senão o trabalho crítico do pensamento sobre o próprio pensamento? Se não consistir em tentar saber de que maneira e até onde seria possível pensar diferentemente, em vez de legitimar o que já se sabe? Existe sempre algo de irrisório no discurso filosófico quando ele quer, do exterior, fazer a lei para os outros, dizer-lhes onde está a sua verdade e de que maneira a encontrar, ou quando pretende demonstrar-se por positividade ingênua; mas é seu direito explorar o que pode ser mudado no seu próprio pensamento, através do exercício de um saber que lhe é estranho (FOUCAULT, 1994, p. 13).

Esse lugar do filósofo como aquele que realiza diagnósticos pode ser comparado ao lugar do filósofo para Sócrates, se olhamos pelo ângulo do cuidado de si, de que estamos tratando no contexto deste trabalho:

Sócrates diz que, na atividade que consiste em incitar os outros a se ocuparem consigo mesmos, ele desempenha, relativamente a seus concidadãos, o papel daquele que desperta. $\mathrm{O}$ cuidado de si vai ser considerado, portanto, como o momento do primeiro despertar. Situa-se exatamente no momento em que os olhos se abrem, em que se sai do sono e se alcança a luz primeira: este, o terceiro ponto interessante na questão do "ocupar-se consigo mesmo". E, finalmente, o término de uma passagem que também não li: a célebre comparação entre Sócrates e o Tavão, este inseto que persegue os animais, pica-os e os faz correr e agitar-se. O cuidado de si é uma espécie de aguilhão que deve ser implantado na carne dos homens, cravado na sua existência, e constitui um princípio de agitação, um princípio de movimento, um princípio de permanente inquietude no curso da existência (FOUCAULT, 2006a, p. $11)$.

Podemos pensar que esse lugar deve ser constantemente reinstalado para o resgate de uma ética pela vida que ultrapasse o domínio da ciência, que tomou para si a responsabilidade sobre a vida humana. Essa perspectiva se dá a partir de uma ideia de vida diretamente contraposta à ideia de morte, tudo muito restrito ao campo biológico, a uma perspectiva no sentido de natureza fisiológica humana. Isso traz sérios problemas éticos, que estão sendo discutidos na atualidade por um viés conservador, que encontram respaldo justamente nesse arcaboço biológico, que ancora, por exemplo, a questão da identidade e da sexualidade nos moldes de uma moral voltada para a reprodução - da vida biológica. E se começarmos a nos interrogar sobre a vida em um sentido ético? Que discursos poderíamos começar a 
emitir no que diz respeito à vida no seu aspecto mais geral, como, por exemplo, no que diz respeito às minorias, às classes menos favorecidas etc.? Os discursos a respeito do outro são emitidos sem o crivo de uma reflexão voltada para uma ética. Não seria esse o papel da filosofia hoje? O resgate de uma ética da vida em um sentido amplo?

A apreensão dos modos de vida e das relações entre as pessoas por um prisma moral acaba fortificando preconceitos e posicionamentos conservadores, não abrindo espaço para o questionamento sobre os critérios que sustentam tais saberes. A tarefa de questionar o que parece natural deve ser sempre relançada, pois os jogos de força orientados pelo poder sustentam os saberes que vão ao encontro dos seus interesses. Mas, pela via da resistência, ao menos, esses pilares podem sofrer um abalo.

\subsection{O corpo científico tem base em uma fisiologia moral da carne}

O biopoder é uma categoria chave para pensar o cuidado de si na Modernidade. O poder que afirma cuidar da vida, não só da espécie humana, mas também do meio ambiente, do planeta, acaba definindo o horizonte político na atualidade, que tem uma ciência aprisionada pela lógica do capital. Esse poder encontra-se entrelaçado em saberes que estão envolvidos em disputas e que possuem interesses controversos. Assim, da mesma forma que a ciência se transforma em ciência aplicada, em tecnologia, com o surgimento das máquinas industriais em meados do século XVIII, na Inglaterra, o corpo circunscrito por uma carne forjada pelo cristianismo, especificamente pela pastoral cristã, será atravessado pelas práticas, e seus respectivos saberes, próprias a determinadas esferas sociais, transformando-se em outro corpo - o corpo científico.

$\mathrm{O}$ que Foucault descobre no curso Os anormais, quando trata do procedimento e da tecnologia de governamentalidade engendrados pela pastoral cristã, é que o corpo que adentra a ciência moderna é formado por um fragmento da moral engendrado no panorama da penitência. E mostra também, como veremos a partir do recorte que Foucault faz da Antiguidade, que a moral que nos conduz até hoje não foi simplesmente engendrada pelo cristianismo, que seria, por sua vez, a moral triunfante, se comparada a modos anteriores de se conduzir. Nesse curso, deparamos com uma bifurcação bem significativa, que mostra, inclusive, que, para alguns autores, houve um momento em que se verifica uma descristianização e a 
carne que adentra o corpo científico ganha outro desenho. Estamos trazendo essa perspectiva para tornar mais complexa a ideia de que a moral pela qual nos conduzimos hoje seja basicamente delineada pelo cristianismo.

Da mesma maneira que, para Foucault, não existe um sujeito universal, o sujeito é uma invenção, não há uma sexualidade concernente a esse suposto sujeito - sendo a sexualidade também uma invenção. Assim, Foucault não perguntará a esse sujeito ideal sobre "sua" sexualidade. As pesquisas em torno da noção de sujeito, de sexualidade ou de qualquer outro domínio buscarão investigar quais relações convergiram, a partir de uma espécie de conjunto de forças, para, em cada estrato da história, produzir sujeitos. Em vez de investigar nos discursos dos indivíduos quais relações de poder os teriam conduzido a essa ou aquela forma de sujeição, Foucault engendra um ponto de vista das relações de sujeição por uma perspectiva voltada para a produção de subjetividades referentes a uma época determinada, desenhando, entretanto, uma saída para essa relação entre sujeito e sujeição, ao inaugurar o campo da subjetivação.

No curso Os anormais, a partir da análise de uma documentação referente ao procedimento da confissão da Idade Média, Foucault faz um "diagnóstico" referente ao domínio da sexualidade, apontando para uma ligação entre a carne estabelecida a partir da pastoral cristã e a carne que vai se imiscuir ao corpo racional e científico da Modernidade. Ele traça assim um vetor referente à carne característica de um certo sujeito (para Foucault, são várias carnes). É importante lembrar que o enfoque da arqueologia suspende a ideia de um sujeito único, que teria percorrido toda a história, fazendo valer sua dissimetria a partir dos jogos de força que produziram subjetividades. Esse curso mostra que o corpo de prazer e de desejo nasce no cerne das práticas de confissão e direção de consciência da pastoral cristã - a nova pastoral, nascida da Reforma e do Concílio de Trento. Na Idade Média, a pastoral cristã e suas práticas de confissão concebiam o corpo, ou a carne, como sendo a sede do pecado da alma. Aos poucos, as práticas de confissão passariam por transformações que engendrariam um corpo foco de prazer, que, por sua vez, seria objetivado e posto sob a mira das práticas de exame. No século XVII, pode-se observar o irrompimento de um objeto, fruto de uma prática religiosa e moral associada à prática científica - o corpo objetivado e que servirá à prática do exame. Foucault delineia três vetores principais que conduziram a pesquisa desse livro. O nosso interesse aqui se volta para o momento em que ele trata do 
surgimento desse "corpo sensível e complexo da concupiscência", que vai acarretar a formação de um determinado corpo racional e científico:

Do corpo dessa materialidade corporal à qual a teologia e a prática penitencial da Idade Média referiam simplesmente a origem do pecado, começa a se destacar esse domínio ao mesmo tempo complexo e flutuante da carne, um domínio ao mesmo tempo de exercício de poder e de objetivação. Trata-se de um corpo que é atravessado por toda uma série de mecanismos chamados "atrações", "titilações" etc.; um corpo que é a sede das intensidades múltiplas de prazer e deleitação; um corpo que é animado, sustentado, eventualmente contido por uma vontade que consente ou não consente, que se compraz ou se recusa a comprazer. Em suma: o corpo sensível e complexo da concupiscência. É isso, creio eu, que é o correlativo dessa nova técnica de poder. E, justamente, o que eu queria lhes mostrar era que essa qualificação do corpo como carne, que é ao mesmo tempo uma desqualificação do critério como carne; essa culpabilização do corpo pela carne, que é ao mesmo tempo uma possibilidade de discurso e de investigação analítica do corpo; essa consignação, ao mesmo tempo da falta no corpo e da possibilidade de objetivar esse corpo como carne - tudo isso é correlativo do que podemos chamar de um novo procedimento de exame (FOUCAULT, 2011b, p. 174).

Esse corpo objeto do exame vai funcionar a partir de então como sede, como campo de formação da noção de anomalia, sendo totalmente superposto ao campo da sexualidade. Essa relação entre o problema do anormal e da sexualidade se estabelece, em parte, pela via da codificação, já que esse campo geral de anomalia vai sendo reportado aos fenômenos da herança e da degeneração. Isso resulta no fato de o campo de análise médica e psiquiátrica das funções da reprodução passar a ser tratado a partir do instrumental utilizado na análise da anomalia. A outra parte cabe à associação entre anomalia e anomalia sexual, isso pela via da reprodução. $\mathrm{O}$ que será reconhecido como anomalia sexual se apresenta inicialmente como um grupo de casos particulares de anomalia e, rapidamente, em torno do período de 1880-1890, ganhará lugar e função de alicerce no campo geral da anomalia, a anomalia sexual funcionando como princípio etiológico geral de qualquer anomalia que venha a aparecer desde então (FOUCAULT, 2011b, p. 143).

A partir dessas duas associações, Foucault vai sustentar que os discursos referentes à sexualidade pertinentes ao campo da medicina não emergiram devido a algum tipo de avanço técnico e médico que teria combatido gradualmente um interdito da sexualidade desde os séculos XVII ou XVIII. O que ocorre quando se passa a falar de sexualidade não é a eliminação de uma censura ( $A$ vontade de 
saber). Nessa perspectiva, trabalhada nessa fase de sua obra, um pouco antes de fazer o giro para a Antiguidade, em que associa a carne desenhada pelas práticas de confissão forjadas pela pastoral cristã, ele vai mostrar que, no Ocidente, a sexualidade não vem de uma interdição, e sim da obrigação de se revelar. E quando se era obrigado a calar, era para que em algum lugar determinado se fosse obrigado a falar desta ou daquela maneira. Foucault vai se ater ao poder que sustenta a prática da revelação forçada:

Foi sempre em correlação com esta ou aquela técnica da revelação obrigatória que foram impostas certas regiões de silêncio, certas condições e certas prescrições de silêncio. O que, a meu ver, é primeiro, o que é fundamental é esse procedimento de poder que é a revelação forçada. É em torno desse procedimento que é necessário identificar, cuja economia é necessário ver, que a regra de silêncio pode atuar. Em outras palavras, não é a censura que é o processo primário e fundamental. Quer se entenda a censura como um recalque, quer simplesmente como uma hipocrisia, trata-se em todo caso de um processo negativo ordenado a uma mecânica positiva, que tentarei analisar (FOUCAULT, 2011b, p. 145).

Foucault, a partir de uma série de casos, aponta que, na ocasião em que eclodem os campos da anomalia, vemos emergir logo em seguida o problema da sexualidade cumprindo funções de policiamento. Essa fusão começa a aparecer entre 1845 e 1850 e as principais referências na psiquiatria são Griesinger, na Alemanha, e Baillarger, na França. Os títulos de seus artigos ilustram a associação entre anormalidade e sexualidade, como, por exemplo, em um artigo de Baillarger, de 1857, intitulado "Imbecilidade e perversão do senso genésico" (FOUCAULT, 2011 b, p. 144). Então, quando o campo da anomalia passa a fazer parte do domínio de ingerência legítima da psiquiatria, a sexualidade também é transposta para esse domínio, ou seja, esse vínculo tem data de nascimento e história, pois nem sempre foi assim. Na medicina da alienação mental, os elementos referentes à sexualidade não tinham expressividade: a descoberta dos instintos ocorre posteriormente, se articulando a outros saberes, convergindo na medicina da anomalia.

A trajetória de Foucault persegue, portanto, a prática da revelação. Ele identifica que o ritual da penitência não contava em sua origem com essa prática e seu papel se transformará no decorrer do período que vai da Idade Média ao século XVII. A exigência da revelação não estava colocada no panorama da penitência do cristianismo primitivo. A revelação funcionava apenas como um estatuto que podia 
ser utilizado ou não pelas pessoas em determinado momento da vida, fazia parte de uma espécie de código dos costumes, podemos dizer assim. Então, por exemplo, as razões que levavam as pessoas a adotar a penitência estavam ligadas aos mais diversos fatores - podiam estar relacionadas a um pecado enorme e escandaloso, ou não. Sua principal característica é que funcionava como estatuto que, uma vez adotado, se tornava definitivo:

Só se podia ser penitente uma vez na vida. Era o bispo, e somente o bispo, que tinha o direito de conferir, a quem o pedia, o estatuto de penitente. $\mathrm{E}$ isso numa cerimônia pública, durante a qual o penitente era ao mesmo tempo repreendido e exortado. Depois dessa cerimônia, o penitente entrava nessa ordem da penitência, que implicava o uso do cilício, de hábitos especiais, a interdição dos cuidados de limpeza, a exclusão solene da igreja, a não participação nos sacramentos, em todo o caso na comunhão, a imposição de jejuns rigorosos, a interrupção de toda a relação sexual e a obrigação de sepultar os mortos. Quando o penitente saía do estado de penitência (às vezes, ele não saía e permanecia até o fim da vida), era em consequência de um ato solene de reconciliação, que suprimia seu estatuto de penitente, não sem deixar certo número de vestígios, como a obrigação de castidade, que em geral durava até o fim da vida (FOUCAULT, 2011b, p. 146).

Fica evidente que se trata aqui de um ritual em que não está demarcada a exigência de uma revelação pública dos erros, nem mesmo no que diz respeito ao que o penitente relatava ao bispo - os motivos e as justificativas que exprimiam a finalidade de se alcançar o estatuto de penitente -, não se tratava da ideia de uma confissão geral dos pecados de uma vida inteira. Nesse esquema, a ideia de uma revelação não era apresentada em uma direção de remissão dos pecados.

A partir desse antigo sistema emergirá, em torno do século VI, o que se denominou penitência tarifada, relacionada com uma operação chamada satisfação. Cada pecado encontra no catálogo de penitências obrigatórias uma penitência correspondente, daí a designação penitência tarifada. Nesse sistema, o pecado só podia ser redimido a partir de uma satisfação que correspondesse a ele, não havia nenhuma cerimônia suplementar. Foucault mostra que o "pequeno núcleo da revelação" começa a se organizar nesse panorama da penitência tarifada, de origem irlandesa, e não latina, e de origem judiciária e leiga.

Esse núcleo de revelação vai se sobressair por volta do século VIII, até o século $\mathrm{X}$, pelo fato de o ato de revelar, por si só, manifestar um sentimento de vergonha, ainda que não tivesse o poder de redimir pecados. Desse modo, acabava 
funcionando como uma expiação, já que a revelação feita ao padre era um tanto penosa. É a partir dessa importância dada ao gesto de confessar os pecados que serão produzidos alguns deslizamentos significativos, uma espécie de estreitamento em torno da revelação, com a humilhação (erubescentia), que passa a desempenhar o papel de eixo da pena. Com a força que o gesto de humilhação ganha, outro esquema de confissão vai irromper em torno dos séculos IX, X, XI: a confissão entre leigos. Como o sentimento de humilhação próprio da revelação produzia a remissão dos pecados, o foco da confissão entre leigos vai se voltar para ela, roubando a cena da confissão sob o poder do padre e do bispo. Mas, posteriormente, do século XII ao início do Renascimento, o poder eclesiástico, já fortalecido, vai resgatar para si o procedimento da revelação, organizando uma série de operações, como a imposição de uma regularidade da confissão, a exigência de uma continuidade e de uma exaustividade no ato da confissão:

A essa extensão considerável vai corresponder um poder do padre que é ampliado nas mesmas proporções. [...] O que vai garantir a exaustividade é que o padre não vai mais se contentar com a revelação espontânea do fiel, que vem vê-lo depois de ter cometido uma falta e por ter cometido uma falta. O que vai garantir a exaustividade é que o padre vai controlar pessoalmente o que o fiel diz: ele vai pressioná-lo, vai questioná-lo, vai precisar sua revelação, por toda uma técnica de exame de consciência (FOUCAULT, 2011b, p. 150).

Desse modo, no século XII, a revelação estará por completo sob domínio do padre, que não terá mais como referência a aplicação da tarifa das satisfações. Ele passa a determinar as penas de acordo com os pecados das pessoas como the convém, dando peso também aos fatores circunstanciais. O relato dos pecados, com o enrubescer que lhe é característico, perde importância. O padre se torna o único que pode obter a remissão dos pecados e, desse modo, a penitência se transforma em um sacramento:

A penitência se torna, nesse momento, em sentido estrito, um sacramento. É somente no século XII-XIII que se forma essa teologia sacramental da penitência. Até então a penitência era um ato pelo qual o pecador pedia a Deus que o redimisse de seus pecados. A partir do século XII-XIII é o próprio padre que, dando livremente sua absolvição, vai provocar essa operação de natureza divina, mas com mediação humana, que será a absolvição. Daí em diante, podemos dizer que o poder do padre é firmemente ancorado no interior do procedimento da revelação das faltas (FOUCAULT, 2011b, p. 151). 
Essa economia central e geral da penitência, que se constitui sacramental no decorrer da Idade Média, é a mesma que funciona até hoje. O que a simboliza é a obrigatoriedade de uma revelação completa - onde nada pode ser suprimido -, a ênfase conferida à extensão - tudo deve ser relatado, não apenas os pecados graves - e, por fim, o incremento do poder e do saber do padre - já que é ele quem, no interior do sacramento da penitência, vai controlar o que se diz e vai interrogar daí por diante a partir das balizas de saber definidas por ele, a partir de sua experiência e seus conhecimentos morais e teológicos.

Essa fase da história admite opiniões divergentes. Para alguns historiadores, a datar do século XVI, dá-se início a um processo de descristianização. Outros historiadores tratam essa fase como uma fase de cristianização profunda. Esse esquema em voga em torno da prática da confissão/absolvição acarretará a proliferação de técnicas adjacentes relativas ao procedimento geral do exame. É assim que vai se desenvolver a prática da direção de consciência, colada a esses procedimentos gerais de confissão.

Para Foucault, é o estabelecimento, no interior do aparato religioso, desse vasto campo discursivo - na forma de um relato total da existência - que servirá como panorama para a instalação das técnicas de exame e medicalização que serão desenvolvidas posteriormente. Esse novo aparato, vinculado ao poder empírico do olho, do olhar, do ouvido, da audição do padre, é o que ele nomeia de governo das almas:

No momento em que os Estados estavam se colocando o problema técnico do poder a exercer sobre os corpos e dos meios pelos quais seria efetivamente possível pôr em prática o poder sobre os corpos, a Igreja, de seu lado, elaborava um governo das almas, que é a pastoral, a pastoral definida pelo Concílio de Trento e retomada, desenvolvida em seguida por Carlos Borromeu (FOUCAULT, 2011b, p. 152).

Ao mesmo tempo em que a prática da penitência se expandia e ganhava cada vez mais peso, no interior dessa pastoral uma literatura dirigida para os confessores, e outra para os penitentes, foi sendo produzida paralelamente - literatura, mostra Foucault, de "partidas dobradas", ou seja, uma funcionando como reverso da outra. Mas tal literatura se sobressai pelo lado do padre por ele possuir o domínio técnico de governo das almas. É nesse material que será encontrada a análise do 
procedimento do exame que diz respeito ao padre, e somente a ele, e que gradativamente vai dominar o território da penitência, expandindo-se além de suas fronteiras. Essa literatura indica ao padre algumas virtudes essenciais à prática da confissão, tais como o poder e o zelo. O poder concernindo ao caráter sacerdotal e à autorização fornecida pelo bispo; e o zelo, concernindo ao desejo. Essa literatura demarca que o zelo, ${ }^{33}$ ou o desejo, ou o amor, no que diz respeito ao padre, se distanciava do amor da concupiscência, tratava-se de um amor de benevolência, capaz de distanciar o confessor do interesse pelos outros e de combater aqueles que resistem a Deus. É esse tipo de amor que deve estar presente no ato da confissão, no sacramento da penitência. O padre deve ser santo, no sentido de que não deve estar em estado de pecado mortal. Essa santidade do padre é entendida aqui como o fato de ele estar obstinado na prática da virtude devido ao contato com as tentações a que a atividade da penitência vai exigir.

Assim, a santidade do confessor se torna necessária como uma espécie de armadura de proteção, como garantia de que, ao escutar o pecado no momento mesmo de sua enunciação, ele não se impregnará. Então, no nível do enunciado, o confessor é preservado do contato com os sentimentos de culpa de quem enuncia a confissão pelo distanciamento afetivo em relação a seu objeto. $\mathrm{O}$ confessor se mantém como alguém impermeável ao desejo manifestado pelo confessor, daí o princípio de santidade.

É necessário, enfim, que o padre que confessa tenha um santo horror dos pecados veniais. E isso não apenas no que concerne aos pecados dos outros, mas aos seus próprios. Porque, se o padre não possui, se não é animado pelo horror aos pecados veniais, no que concerne a si mesmo, sua caridade vai se apagar como o fogo é apagado pela cinza. De fato, os pecados veniais cegam o espírito, grudam na carne (FOUCAULT, 2011 b pp. 153-4; grifo meu).

Esse curso, em cima de tratados da época tão específicos, mostra que o conjunto de regras que passa a fazer parte da nova prática da penitência produz uma extensão dos mecanismos de discurso, das técnicas de exame e de análise no âmago do sacramento da penitência. A vida inteira dos indivíduos se imiscui no procedimento do exame geral, para além das estreitas fronteiras da absolvição, tal como se deu na época da penitência tarifada. E, nos meios mais cristianizados, a

\footnotetext{
${ }^{33}$ Foucault toma como base um tratado de prática penitencial escrito por Habert no final do século
} XVII. 
figura do diretor de consciência ganha forma e função - orientar aqueles que pretendem se aperfeiçoar por meio de um filtro discursivo no qual os mais ínfimos detalhes de toda a vida do indivíduo devem ser relatados.

Foucault indica também um deslizamento que ocorre a partir desses procedimentos gerais do exame. Trata-se do lugar que a luxúria vai ocupar no espaço do exame. $\mathrm{O}$ que feria basicamente o sexto mandamento estava relacionado aos vínculos jurídicos entre as pessoas: o adultério, o incesto e o rapto. Desde o século XVI, o que Foucault vai denominar de aspecto relacional da sexualidade sofrerá uma transformação relevante. A ênfase dada ao aspecto relacional se desloca para o corpo do penitente. Conforme Foucault sublinha, "seus gestos, seus sentidos, seus prazeres, seus pensamentos, seus desejos, a intensidade e a natureza do que ele próprio sente é que vai estar agora no foco mesmo desse interrogatório sobre o sexto mandamento" (FOUCAULT, 2011b, p. 160). Trata-se agora de um esquadrinhamento do corpo, uma espécie de cartografia pecaminosa do corpo, um recentramento geral do pecado da carne no corpo, onde a carne adentra o corpo. $\mathrm{O}$ pecado da carne que se estabelecia ao se violar a regra da união, doravante, passa para o próprio corpo. Assim, deve-se interrogar o corpo, persegui-lo em suas instâncias mais sensíveis para deter o pecado da carne.

O problema que anteriormente se colocava para os escolásticos sofre uma modificação - o ato real e o pensamento dão lugar a novas instâncias de controle: o desejo e o prazer. O problema da intenção e da realização, no que concerne ao pecado, se torna insuficiente nesse novo panorama.

\subsection{0 sujeito da psicanálise como inventor de si mesmo}

A nós, filósofos, não nos é dado distinguir entre corpo e alma, como faz o povo, $e$ menos ainda diferenciar alma de espírito. Não somos batráquios pensantes, não somos aparelhos de objetivar e registrar, de entranhas congeladas - temos de continuamente parir nossos pensamentos em meio a nossa dor, dando-lhes maternalmente todo o sangue, coração, fogo, prazer, paixão, tormento, consciência, destino e fatalidade que há em nós. Viver - isso significa, para nós, transformar continuamente em luz e flama tudo o que somos, e também tudo o que nos atinge; não podemos agir de outro modo.

Nietzsche, A gaia ciência

No campo psicanalítico, o analista se autoriza, por si mesmo, a partir de um crivo ético instaurado na relação do sujeito consigo mesmo, dada sua condição de 
sujeito analisante, antes de sua passagem ao lugar de analista. Tal gesto pode parecer um escândalo para a comunidade científica tradicional, pautada em um modelo de ética positivista própria ao campo científico. O que pretendemos mostrar a partir de agora é que, nesse sentido, a psicanálise vai se orientar por outra perspectiva ética, também rigorosa, só que estabelecida por elementos provenientes do âmbito do cuidado de si, terreno do sujeito.

Por exemplo, quando hoje falamos sobre alguém que dá início a um processo terapêutico, imediatamente se tem a ideia, proveniente do que se concebe como cuidado moderno, de que o indivíduo em questão está com problemas pessoais dos quais não consegue dar conta sozinho. Isso leva certo senso comum a entender como evidente a necessidade de existir na área de saúde - que, como vimos no decorrer deste trabalho, é o mesmo que dizer no mercado de saúde - um campo de especialistas voltados para o atendimento das demandas dos problemas ditos psicológicos e psiquiátricos, dando maior enfoque às dores da existência por critérios científicos. O especialista codifica, a partir dos saberes médicos, a saúde e a doença dos indivíduos às vezes de modo reducionista. $\mathrm{O}$ que nos interessa neste ponto não é destituir de valor os conhecimentos adquiridos no campo da medicina, mas abrir uma reflexão sobre esse campo no sentido de uma análise do uso que os sujeitos podem fazer desses saberes, que, historicamente, segundo Foucault, se confundem com o poder de polícia.

Hoje somos estimulados por uma cultura que aponta para um ideal individualista, no qual aquele que se mostra como se bastando a si próprio é considerado forte e o interesse pela vida em coletivo torna-se esvaziada, em que parece haver espaço só para alguns, o que gera um sentimento de disputa, concorrência, perdendo-se de vista o gosto pela multiplicidade, que tanto pode abrilhantar a vida.

É claro que a crise e o pedido de socorro são uma direção de trabalho de si, mas o que queremos dizer aqui é que, na verdade, se um indivíduo voltar o olhar para si mesmo, já será capaz de sentir algum impacto diante do fato da existência e, no contato consigo mesmo, pode vir a refletir sobre aquilo que está realmente fazendo com sua própria vida. Tal caminho pode ser, digamos, uma entrada opcional em uma crise estabelecida pelo próprio indivíduo, ao constatar, por exemplo, traço típico da nossa época, estar vivendo em um estado de anestesia, pois em tempos que nos levam a viver como que sob o efeito de narcóticos, no sentido 
concreto e metafórico do termo, a nos conduzir como robôs, um trabalho que nos direcione à percepção de que somos criaturas e que nos criamos a partir de nossas limitações, que somos sensíveis, por isso sentimos alegria e podemos apreciar as coisas belas da vida, mas também por esse motivo sofremos, é um trabalho de subversão que ultrapassa a esfera da rebeldia, ou seja, passa por ela, claro, mas instaura, a partir da experiência humana, elementos, recursos, sensações, coisas que digam respeito à experiência de estar vivo - uma experiência estética. A partir do fato de que, como aprendemos com Marx, somos seres sociais autoproducentes, ${ }^{34}$ pois o mundo do trabalho produz a nós mesmos, talvez a nossa transformação em seres obedientes tenha sido facilitada no que diz respeito a vários aspectos bem complexos, como pudemos ver no decorrer deste trabalho. Mas é essa mesma determinação, de que somos seres que vivemos em sociedade e que nos produzimos a nós mesmos, que pode nos levar a encontrar saídas frutíferas e, portanto, mais potentes.

A questão do desejo, reiteradamente colocada por Lacan, pode ser problematizada na linha da hermenêutica, apresentada criticamente por Foucault. Com isso queremos dizer que as linhas traçadas por Nietzsche, Freud e Marx apontam para a constituição de um olhar voltado para técnicas de interpretação de si e do coletivo, no sentido de "técnicas de cura" da sociedade, em Marx; do indivíduo, em Freud; e da humanidade, em Nietzsche, tal como citado anteriormente na ocasião do colóquio sobre Nietzsche, Freud e Marx (FOUCAULT, 2008, p. 40).

Se o sujeito se permite um movimento de inflexão de si para si mesmo, tornase possível desmistificar o desejo, ou seja, em vez de apreendê-lo como aquilo que deve necessariamente ser realizado - segundo a ditadura do consumo, relacionada ao individualismo próprio à nossa época -, traçando para si uma direção de trabalho, no sentido de dar à vida um certo movimento, pode passar a enfrentá-la a partir de uma ótica mais complexa, que comporta a sua dimensão trágica. Lembremos que quando Foucault se refere à vida, ao afirmar a importância de retomarmos a noção

\footnotetext{
${ }^{34}$ Jacob Gorender, na apresentação de $O$ Capital I, diz que, "do ponto de vista da antropologia, o que sobreleva é a relação do homem com a natureza por meio do trabalho e a humanização sob o aspecto de autocriação do homem no processo de transformação da natureza pelo trabalho. As mudanças das formas de trabalho constituem os indicadores básicos da mudança das relações de produção e das formas sociais em geral do intercurso humano. O trabalho é, portanto, o fundamento antropológico das relações econômicas e sociais em geral. Ou seja, em resumo, o que Marx propõe é a antropologia do homo faber" (2013, p. 32).
} 
de cuidado de si para refletirmos os problemas da nossa época, ele traz à baila o caráter de incerteza e de perigo:

Vemos como, nessa prática de si, tal como aparece e se formula nos últimos séculos da era chamada pagã e nos primeiros séculos da era cristã, o eu surge fundamentalmente como a meta, o fim de uma trajetória incerta e eventualmente circular que é a perigosa trajetória da vida (FOUCAULT, 2006a, p. 304).

Na prática psicanalítica, o sujeito do inconsciente é aquele que aparece para, no instante seguinte, desaparecer. Aqui, com Foucault, podemos construir uma aproximação, no sentido de que nos interessa pensar um sujeito que ganhe determinada forma para que, no instante seguinte, possa se transformar, já que a vida é múltipla, inconstante e dinâmica - uma estética da existência. Isso vai contra o ideal de fornecer à vida um sentido monumental. A vontade, no campo psicanalítico, pode ser pensada em uma direção de trabalho que se volte a dar formas à existência, a fazer da vida algo produtivo e belo.

Nietzsche apresenta a ideia de "adoecimento da vontade", que aponta para um anseio de comando (NIETZSCHE, 2001, pp. 240-1). Lacan trabalha a noção de sujeito como sendo um sujeito em conflito com o desejo, formulado a partir dos diversos discursos de autoridade que ganharam força em um mundo delineado pela moral cristã, que não elaborou a morte de Deus e a decorrente lacuna aberta com esse fenômeno.

O discurso analítico é produzido a partir de uma profundidade, não no sentido da ideia de interioridade, pois esta foi engendrada pela tradição cristã, como vimos no subcapítulo intitulado "O corpo científico tem base em uma fisiologia moral da carne”. Trata-se de uma profundidade no sentido de uma volta para si mesmo, uma certa desmistificação da cultura, da ordem estabelecidada de fora, da ditadura capitalista que hoje estimula os sujeitos consumidores a um gozo excessivo de bens materiais, produzidos pelo circuito capitalista, exterior ao campo do sujeito.

O trabalho analítico de produção de discursos por meio da emergência do sujeito do inconsciente é obviamente disruptivo. Rompe as barreiras dos discursos forjados pela consciência, que, como vimos no decorrer deste trabalho, relacionamse com a demanda social, embasada, por sua vez, no biopoder. Desse modo, o discurso que emerge do inconsciente, por não ser assimilado por completo pelo 
conjunto social, já que diz da esfera singular do sujeito, pode ser considerado como elemento de uma salvação de si na nossa época, salvaguardando uma série de questões, mas, ao mesmo tempo, entendendo que a descontinuidade nos permite forjar essa linha de pensamento, aproximando as técnicas de si antigas com uma técnica de si atual.

Pela via do discurso, tal como nos antigos, porém com os elementos modernos, entendemos que o trabalho da subjetivação deve ser feito em uma dimensão de profundidade, a partir de um processo de enunciação de si. Essa direção é oposta à ideia de que a enunciação de discursos verdadeiros se dá muitas vezes como um trabalho de resistência a uma série de demandas estipuladas por determinadas convenções sociais.

A produção do discurso sobre si mesmo instiga uma direção de atividade no campo do sujeito, no contexto de uma ética de si e do outro, em um contexto de produção afetiva para além dos mecanismos de recompensa e punição característicos da disciplina que ainda vigora hoje, em que os indivíduos encontram suas bases: ora se sentindo potentes, devido ao aparato de recompensa, ora se sentido humilhados pelos mecanismos de punição, já que a cultura que nos constitui é uma cultura de valores. Mas, se o sujeito pode se constituir a partir de uma produção sua, ao abrir um campo de produção de discursos em meio a uma crise existencial, por exemplo, instaurando um campo da subjetividade, ele começa a se orientar a partir de outros valores, a partir de uma perspectiva de mundo sua.

Em certo grau, esse processo pode contribuir para despotencializar as fantasias paranoicas dos indivíduos neuróticos, geralmente doentes por serem muito autorreferentes, por possuírem um mundo girando em torno de um si mesmo produzido pelas instâncias legitimadas pelo biopoder. $O$ processo de autofinalização do eu pode nos levar a pensar na questão do narcisismo, noção chave para a psicanálise. Na nossa época, o processo de subjetivação se ancora em um conjunto de forças individualizantes, desviando o indivíduo da alteridade. É preciso resgatar o interesse pelo outro, pelo diferente, inaugurar uma dimensão de trabalho que extrapole a esfera dos interesses narcísicos, que possa gerar uma vontade de participação ativa, uma micropolítica na qual nossa vontade de transformar as coisas seja levada em conta, ganhando lugar e formando coisas que possam vir a existir ou não. Fazer política não precisa ser uma atitude vinculada a um partido político, ou seja, a política não precisa ser necessariamente um objeto 
que entendemos como pertencente ao campo da política. Fazer política pode ser outra coisa. Por exemplo, pode ser como determinados pais se apresentam em uma reunião da escola do filho - se pensando apenas no sucesso de seu filho, ou lançando um olhar mais voltado para o seu filho como parte de um coletivo, que, enquanto coletivo, faz parte de outro ainda maior etc.

O governo de si e o governo do outro acabaram se tornando atribuições da gestão pública, governamental, passando para as mãos dos gestores consagrados pelas instituições estabelecidas. Por esse caminho, os indivíduos acabam não se implicando como parte do processo, geralmente esgotando sua participação no gesto político de votar nas eleições, inquestionável, claro, mas que os faz sujeitos passivos diante da expectativa de que toda a imensa problemática própria a qualquer conjunto social seja resolvida pelos ditos responsáveis. E, como qualquer expectativa idealizada não se realiza na dimensão concreta, vimos a emergência de discursos insatisfatórios e acalorados reivindicando os direitos que todos creem ter. $^{35}$

A prática psicanalítica indica a urgência de se pensar uma direção de trabalho que vise a um redimensionamento do eu na nossa época. Lacan se preocupou em indicar, em vários momentos, a preocupação de que a psicanálise não se voltasse para uma prática burguesa de silenciar os discursos, de que não se abafassem nos limites dos consultórios os discursos que podem formular objetos de luta. A dimensão do conflito é a mina de ouro do trabalho analítico, mas não para ser silenciado, e sim para ser trabalhado para além dos ideiais burgueses, como, por exemplo, a família tradicional. Deparamos, em vários momentos de sua obra, com essa preocupação, tendo em vista o impulso recorrente dos psicanalistas em formação na sua época de fechar as discussões nos conceitos forjados pela psicanálise. Lacan se ocupou em abrir os conceitos da psicanálise, como conceitos chave que visassem operar um trabalho frutífero. Em suas palavras:

O homem contemporâneo cultiva uma certa ideia de si próprio que se situa num nível meio ingênuo, meio elaborado. A crença de que ele tem de ser constituído assim e assado participa de um certo medium de noções difusas, culturalmente admitidas. Ele pode imaginar que ela é oriunda de uma propensão natural, quando, no entanto, no atual estado da civilização ela the é ensinada, de fato, por todos os lados. Minha tese é a de que a técnica de

\footnotetext{
${ }^{35}$ Esse pensamento se aproxima da ideia de minoriade desenvolvida por Kant.
} 
Freud, em sua origem, transcende essa ilusão, que, concretamente, excede uma ação sobre a subjetividade dos indivíduos. A questão é, portanto, saber se a psicanálise vai pouco a pouco se relaxando até abandonar o que foi por um instante entreaberto ou se, pelo contrário, ela vai tornar a patentear seu relevo, e de maneira que o renove (LACAN, 1985, p. 10).

Os efeitos dessa empreitada é que toda essa energia voltada para o eu acabe revertendo em uma abertura para o outro, já que a quebra dessa ideia ilusória que o indivíduo tem sobre si mesmo pode liberar uma energia que se volte para o outro. A clínica psicanalítica, desde Lacan, potencializa o combate aos ideais individualistas pautados nas promessas do capital, já que elas alimentam a suposição da classe burguesa de que os sentimentos mais profundos de satisfação, ligados basicamente à sensação de desamparo, podem ser supridos pela aquisição de bens materiais.

Fazer uma análise crítica desse tipo de expectativa é fundamental para indicar o desvio da questão da constituição de uma subjetividade atada a expectativas materiais, encobertas pelos objetos-fetiche, o que acaba gerando um fenômeno de consumo compulsivo, produzido artificialmente pelas campanhas publicitárias, moduladas pelos ideiais vindos dos veículos midiáticos.

Essas questões são muito graves, principalmente por serem desdenhadas na nossa época. Tudo começa na infância, um momento muito importante, no qual a criança forma sua estrutura psíquica, quando, ao se desenvolver física e psiquicamente, ela se vê diante da tarefa de responder às mais diversas demandas sociais, o que a leva à estruturação de uma subjetividade, um modo seu de se apresentar diante das exigências do grupo social no qual está instalada. Isso faz com que, em vez de se dar um passo à frente em direção à vida, se permaneça fixado às demandas sociais, que mantêm os indivíduos em um circuito narcísico de recompensa e punição desde infância. A tarefa pedagógica efetuada pela escola opera nesse circuito e esse modelo infantil acaba se vertendo para outros lugares sociais. E, muitas vezes, perde-se de vista a importância de se libertar desse circuito perverso e infantil.

Lacan, ao falar do sujeito para a psicanálise, delineou esquemas de formação subjetiva em relação à questão do Outro como dimensão imaginária em que entram as figuras idealizadas - como a figura de Deus ou seus representantes; o próprio sujeito nesse jogo de forças; e as insígnias ligadas às figuras de peso legitimadas 
pela sociedade - como o falo, o desejo, no plano das fantasias - e relacionadas às frustrações inevitáveis da vida, que projetamos automaticamente fora de nós mesmos, responsabilizando um outro. A partir do manejo do modo pelo qual um sujeito foi instaurado, opera-se uma transformação e uma perda narcísica imprescindível que tornam possível um redimensionamento de si mesmo na direção da realidade concreta da vida.

A cultura de si, transportada para os dias de hoje como uma prática de si, consistiria em um trabalho de combate às ilusões, de uma desmistificação daquilo que o indivíduo absorve para si a partir do conjunto de ideais sustentados no campo social. Tais ideais tendem a fazer com que cada um de nós possa se identificar com algo produzido fora do campo do si mesmo. Isso é perfeito para o capitalismo, um sistema que se sustenta daquilo que as pessoas consomem. Se hoje fabricam-se ilusões, se os indivíduos acabam se tornando consumistas compulsivos em busca de concretizar uma imagem de si, que, por se tratar de uma ilusão, não poderá ser concretizada, temos como efeito a produção de uma série de frustações que, advindas desse processo vivido pelos indivíduos, acabam não sendo assimiladas e transformadas em alguma coisa pertencente ao sujeito. $O$ trabalho de formação de uma cultura de si consistiria em um trabalho subjetivo de resistência contra um bloco esmagador e frustante de ilusões.

Nossa proposta aqui não é de modo algum apresentar o que é a psicanálise, apenas pretendemos mostrar uma linha de pensamento que associa seu campo de prática - onde o sujeito formula a si mesmo pelos discursos sustentados na transferência entre analisando e analista - como uma espécie de técnica de si que o sujeito opera consigo, mesmo a partir da postura que assume enquanto sujeito que empreende uma análise. Queremos dizer com isso que encontramos elementos oriundos da epiméleia heautoû no campo psicanalítico, no sentido de que o modo pelo qual se instala o ouvido do analista na situação analítica tem total relação com a direção do tratamento do material produzido pelo analisando, com suas queixas, suas demandas, sua vontade de se transformar a partir do trabalho analítico.

A perspectiva psicanalítica diz de um sujeito que precisa se formular a partir de qualquer evento ocorrido. Para Freud, a culpa inconsciente, que se instala principalmente pelo modo como nossa civilização, pautada no cristianismo, formula as subjetividades - pelos mecanismos de julgamento, culpa ou idealização ligados ao narcisismo -, acaba delineando sentidos para boa parte dos 
acontecimentos vividos pelos indivíduos. E, a nosso ver, esse jogo de culpa assola o indivíduo, esmagando a possibilidade de emergência de um sujeito com mais possibilidades de se realizar, de formular objetos de luta, e o fixa em posições vitimizadas. Devido a esse fato, temos como efeito o sentimento de frustação, e esse afeto, por sua vez, acaba resultando no investimento em um monumento narcísico, em vez de se voltar para o sujeito na dimensão concreta de sua existência, ou seja, de abertura para os acontecimentos, de luta e de obtenção de prazer pela vida, pelo acontecimento de estar vivo. Isso pode gerar um campo de forças voltado para a criação de uma perspectiva de vida na qual, a partir de nossas limitações, possamos entender que, ao construir recursos para lidar com as circunstâncias da vida, obtemos prazer em construir virtudes, criando assim um modo de enfrentar a vida que ultrapasse os limites da moral, no sentido de combate à ideia de constituição de uma subjetividade passiva, aprisionada em si mesma, sob os tormentos inevitáveis do percurso de cada um. Essa passividade é fruto do ideal cristão, que modela as subjetividades de acordo com um ideal de humildade, mediante o investimento em uma vida rica no reino dos céus, ao qual só os mais modestos terão acesso.

Se, no lugar de um posicionamento de enfrentamento da vida, o sujeito passar a esperar da vida um sentido pleno, qualquer espécie de grande sentido, ele acabará voltando suas forças para o investimento em grandes monumentos imaginários, encarando, inclusive, a si mesmo como monumento narcísico. Como efeito, deparamos com um ideal de eu fadado a ilusões e à perda da dimensão ética da vida no coletivo.

Não é à toa que Nietzsche critica a ideia de atribuir à vida qualquer grande sentido que tenha dado lugar ao ideal ascético. Em Função e campo da fala e da linguagem em psicanálise, Lacan trabalha um ponto que nos interessa aqui e que tem total relação com o problema da questão da objetivação do sujeito, levantado no corpo desta tese. Não é de agora que nos deparamos com esse problema, como pudemos observar. Ele tem suas raízes fincadas no solo da ciência, solo cultivado pelos saberes científicos, que, por sua vez, como mostra Foucault, é o poder científico.

A psicanálise nasce na contracorrente do saber científico e deve se manter assim, já que seu objeto, o inconsciente, e o sujeito que emerge desse campo não condizem com o sujeito da consciência e da ciência. Ou seja, ela não se encaixa nos interesses da comunidade científica em voga. É conhecido o fato de que Lacan tem 
sua produção marcada pela preocupação com o desvio dos psicanalistas em relação à doutrina freudiana. E, a partir dessa preocupação, ele denuncia em vários momentos os desvios de rumo observados na prática dos psicanalistas e nos saberes que eles instituíam. Nesse relatório, proferido no congresso de Roma, em 1957, ele está devidamente ocupado com a questão do campo psicanalítico e com o uso específico dado ao discurso nesse mesmo campo. Não é qualquer fala que atravessa os ouvidos de um analista. O analisante deve fazer um trabalho de formulação de si que passe pelos ouvidos do analista pelo suporte da transferência, suporte esse que conta com algum nível de atividade daquele que se propõe a começar uma análise. Lacan apresenta esse problema pela via das distorções que os psicanalistas conferiram à prática psicanalista e que passa pela forte influência do grupo norteamericano na história do movimento psicanalítico.

Lacan lembra o destaque dado ao setor $C$ no Congresso de Psiquiatria de 1950 como um aspecto recorrente de determinado meio cultural, qual seja, a tendência anti-historicista bem característica da "comunicação" (Lacan coloca o termo entre aspas) própria aos EUA, que vai em uma direção completamente contrária à da psicanálise, como ele diz: "Ao que vem se somar uma forma mental bastante autóctone, que, sob o nome de behaviorismo, domina a tal ponto a noção psicológica na América que está claro que, doravante, supera por completo, na psicanálise, a inspiração freudiana" (LACAN, 1998, p. 246). Lacan está discutindo a questão da formação, apontando para um equívoco a respeito do rigor em relação ao acesso do iniciante no exercício da psicanálise - uma disciplina "que só pode sobreviver ao se manter no nível de uma experiência integral", ou seja, a necessidade de cumprimento de um rigor se estende durante toda a vida daquele que se autoriza psicanalista -, com formalismo enganador, como diz Lacan:

[...] que desencoraja a iniciativa ao penalizar o risco, e que faz do reino da opinião dos doutos o princípio de uma prudência dócil onde a autenticidade da pesquisa se embota antes de se esgotar? A extrema complexidade das noções empregadas em nosso campo faz com que em nenhum lugar um espírito, ao expor seu julgamento, corra mais totalmente o risco de descobrir sua medida. Mas isso deveria trazer a consequência de transformar em nosso propósito primordial, senão único, o franqueamento das teses pela elucidação dos princípios. A severa seleção que se impõe, com efeito, não poderia ficar a cargo dos adiamentos indefinidos de uma cooptação minudente, mas da fecundidade da produção concreta e à prova dialética de argumentações contraditórias (LACAN, 1998, pp. 239-40). 
Lacan reitera o aspecto subversivo inerente à psicanálise, que é justamente o de tratar a dimensão da fala pelo viés da sexualidade e do inconsciente, ou seja, por aquilo que não pode ser capturado pelo meio social, que não pode ser assimilado pela demanda do grupo social. Interessa-nos abordar a ideia de fala sob o prisma do não saber, principalmente por manter viva a dimensão de força capaz de sustentar o sujeito do inconsciente. É justamente sobre aquilo que não se sabe que vai se formar o campo de forças próprias ao uso do sujeito.

Tais forças terão sua potência preservada na medida em que não forem assimiladas pelo prisma empobrecido das demandas sociais, que não cessam de produzir ilusões, que, por sua vez, demandam dos membros desse conjunto social o exato cumprimento das expectativas suscitadas por essas mesmas ilusões. Para Lacan, a psicanálise se descaracteriza quando absorvida pelas exigências advindas do corpo social. Em suas palavras:

De qualquer modo, evidencia-se de maneira incontestável que a concepção da psicanálise pendeu ali para a adaptação do indivíduo ao meio social, para a busca dos patterns de conduta e para toda a objetivação implicada na noção de human relations, e é realmente uma posição de exclusão privilegiada com respeito ao objeto humano que se indica na expressão nascida lá mesmo, human engineering. Portanto, é à distância necessária para manter tal posição que podemos atribuir o eclipse, na psicanálise, dos termos mais vívidos de sua experiência - o inconsciente, a sexualidade -, dos quais parece que a própria menção logo deverá apagar-se (LACAN, 1998, pp. 246-7).

Nossa proposta aqui não é de maneira alguma fazer uma aproximação grosseira entre a psicanálise e a ideia de cuidado de si antigo. O que pretendemos indicar é que a pesquisa de Foucault serve de alerta para tratar de alguns problemas levantados por Lacan. Apostamos que traçar diagnósticos voltados para o manuseio da técnica analítica é uma tarefa ética, e Foucault nos proporciona chaves pertinentes e originais para pensar uma técnica que dialoga com a ciência e que entende operar por uma via que não utiliza os recursos próprios ao campo científico. 


\section{Conclusão}

Ele não via nada e, longe de ficar aflito, fez dessa ausência de visão o ponto culminante de seu olhar. O seu olho, inútil para ver, ganhava proporções extraordinárias, desenvolvendo-se de uma maneira desmesurada e, estendendo-se sobre o horizonte, deixava a noite penetrar no seu centro para receber dela o dia.

Maurice Blanchot, Tomás, o obscuro

A pesquisa foucaultiana das técnicas de si antigas, de governo das almas e de poder modernos nos conduziu a uma experiência ora de intensa aflição, ora de um alívio inexplicável. Foucault nos remete a experiências em torno do saber que deslocam o tempo todo as balizas pelas quais nos orientamos a partir da tradição do pensamento ocidental. Assim, as lentes pelas quais costumávamos enxergar o horizonte a nossa frente se tornaram ineficazes. É aí que precisamos dar um passo adiante e ter coragem de caminhar no escuro. E ter ainda mais coragem para nos guiarmos norteados pelo que conseguimos formular a partir dos nossos próprios pensamentos. Para Foucault, pensamento está relacionado com o percurso do sujeito em direção a sua verdade. É o que ele designa por exercício do pensamento, que, como procuramos mostrar, pode se dar quando o sujeito faz uma dobra em si mesmo, cultivando a si próprio.

Como vimos no decorrer deste trabalho, os filósofos dos séculos I e II instauraram um campo de subjetivação em que o cultivo das virtudes norteava sua existência a partir de técnicas de si que lhes permitiam buscar uma salvação de si muito específica, bem diferente da habitualmente conhecida por nós pela formulação cristã. Tanto o modelo de salvação helenístico-romano quanto o cristão levavam em conta as estruturas de espiritualidade do sujeito, mas de modo bem diferente. No primeiro modelo, como pudemos verificar, havia múltiplas possibilidades de modos de se relacionar do sujeito consigo mesmo e com o outro no que diz respeito ao governo de si e ao governo do outro. Vale lembrar o exemplo de Sêneca, no momento em que vai para o exílio: consola sua mãe, orienta um primo distante e se torna conselheiro de Nero. Nessa ocasião, ele governa a si mesmo ao mesmo tempo em que governa o outro, transformando o contexto do exílio em um campo frutífero de si mesmo. Nesse modelo, pressupõe-se uma ampla atividade do sujeito em direção a si mesmo. 
O modelo cristão de salvação se assenta em estruturas de espiritualidade anteriores, só que a partir de uma manobra, que, em nome de uma salvação de si, vai criar uma carne da concupiscência, desarticulando a relação outrora estabelecida do sujeito consigo mesmo. Essa desarticulação vai compor uma relação consigo em que, doravante, faz-se necessário referir-se a um Outro, introduzindo o critério da purificação para se acessar o que é estabelecido como verdade. Isso funda um novo campo de subjetivação, uma relação do sujeito com a verdade limitada a esses pressupostos de conhecimento de si, pela qual o sujeito vai se tornando cada vez mais passivo, visto que o governo de si mesmo passa a ser delegado ao detentor das técnicas de governo das almas. Nesse modelo, investe-se na figura de um outro idealizado, e a verdade seria um elemento dentro desse circuito, mas não uma virtude do sujeito. Nesse sentido, Castro diz que:

Nos séculos III-IV formou-se o modelo cristão do cuidado de si mesmo. Ainda que em um sentido geral se possa falar de modelo cristão, seria mais correto chamá-lo modelo ascético-monástico. Nele, o conhecimento de si está ligado ao conhecimento da verdade tal como nos é dada no Texto da Revelação. Encontramos uma relação circular entre o conhecimento de si, ou conhecimento da verdade, e o cuidado de si mesmo: não é possível conhecer a verdade nem conhecer a si mesmo sem a purificação de si mesmo, do coração. Em segundo lugar, as práticas de si mesmo têm como função essencial dissipar as ilusões interiores, reconhecer as tentações que se formam dentro da alma, desatar as seduções das quais se pode ser vítima. Em terceiro lugar, o conhecimento de si mesmo não persegue o voltar-se para si mesmo, em um ato de reminiscência, mas a renúncia a si mesmo (CASTRO, 2009, p. 95).

Por essa via, as estruturas de espiritualidade, antes fundamentais para a relação do sujeito com sua verdade, ficam resumidas a esse filtro de purificação e, assim, a possibilidade de o sujeito gerir sua própria existência, o cuidado de si, isto é, o governo de si, perde força - ao contrário da época helenística-romana, em que se priorizava o governo de si em relação ao governo do outro. $\mathrm{O}$ campo de conhecimento, do sujeito relacionado a sua verdade, vai dar lugar ao ideal ascético, nessa relação do sujeito com o Outro. Esse contexto de negação da relação do sujeito consigo mesmo abriu campo para a proliferação de técnicas de exame inaugura-se um novo campo de saber.

O saber, como mostra Marx, nasce no mundo do trabalho, numa organização social em que o homem, a partir da reunião de forças provenientes do grupo, pode 
dominar em parte a natureza e, assim, criar. No entanto, essa capacidade criativa se potencializa de acordo com uma organização que tem a forma de saberes. É aqui que nossa análise entra em cena: o mundo, hoje, mostra que esses saberes podem acabar se tornando puro ornamento, vazios, propícios a tomar rumos bastante obscuros.

A questão do niilismo nos oferece alguma direção nesse aspecto. A falta de sentido própria da Modernidade estaria encoberta por um excesso de sentido moral, engendrado pelo cristianismo, que desenhou um modelo de subjetividade pautado no sofrimento, numa ideia de humildade e passividade que foi associada à ideia de bondade. Desse modo, uma subjetividade ativamente direcionada para uma produção de si, que tenha, por exemplo, um tom de crítica social, acaba sendo associada, na nossa sociedade, a ideias pejorativas como egoísmo, subversão, rebeldia e coisas afins, e recebida com violência pelo senso comum. Aqui deparamos com mais uma noção de Nietzsche - de homem do ressentimento. O homem do ressentimento não parte para a luta, não parte para conquistar o que é seu a seu gosto. Ele entra em acordo com o aparato social, justifica sua dor de existir inerente ao contato do indivíduo com a realidade, culpabilizando o outro, o diferente dele, e alimenta discursos de ódio, preconceituosos etc.

Tudo isso cria uma rigidez, um modo padrão de ser, um individualismo em sociedade em que se perde de vista que tudo o que existe tem relação com o grupo social como um todo. Perde-se a noção básica de responsabilidade pela vida individual e conjunta, desfaz-se a importância de refletir sobre a pólis com gosto, com vontade de fazer da vida uma experiência bela. Acostuma-se com a grosseria da guerra, com a violência e, pior, habitua-se a olhar para as maiores atrocidades produzidas pelo avanço da tecnologia com olhos grosseiros, a partir de uma perspectiva retrógrada e sem espanto. Condicionamo-nos a viver sem a necessidade de criar um espaço de reflexão comprometido com uma ética pela vida em conjunto. Sabe-se, mas finge-se não saber, que aquilo que a mídia nos reporta como informação opera a serviço de uma trama poderosa e obscura, em que um grupo social marginalizado paga com a própria vida, o tempo todo, pelos absurdos que fazem parte de uma organização social como a nossa. Cria-se o hábito de fingir, sem cessar, que um ponto de vista maniqueísta, como o dos meios de comunicação de massa, poderia dar conta de reportar com seriedade, comprometimento e neutralidade os mais diversos problemas sociais. Será que não podemos começar a 
pensar a vida em outros termos? Neste trabalho pensamos que sim, a partir da ideia foucaultiana tão atual de diagnóstico do presente.

A grande mídia informa uma reflexão pronta, cheia de preconceitos estabelecidos, veiculando os mais diversos interesses do poder, hoje, capitalista. Não é à toa que verificamos o êxito do sensacionalismo sobre os fatos mais trágicos. Como mostra Nietzsche, como homens do ressentimento, podemos ser passivos e ávidos por grandes sentidos, o que dá margem para que se explorem tragédias sociais, ou fatos comuns da vida das pessoas eleitas especiais, como as celebridades, por exemplo, um espetáculo sem fim e bem lucrativo, aliás.

Faz-se urgente refletirmos sobre como o modelo individualista em voga hoje, e que não cessa de ser investido pelo poder capitalista, nos faz viver nesse mundo de guerras e lutas sociais, sem que possamos nos lançar em uma experiência estética da vida. Seria uma forma de colocar a questão ética em jogo, mas não pela via da moral. Por essa via já gastamos todas as fichas, a moral deve ser pensada e ampliada. Aqui Freud nos ajuda, pois ele mostra que nossa sociedade absorveu a moral como uma instância crítica (superego) que nos pressiona como sujeitos, da mesma forma que o aparato social. Diante disso, resta-nos ousar mais, lançar mão de recursos mais criativos.

Pensamos pela via de uma resistência a essa produção excessiva de ilusões que é a pedra angular do capitalismo. O fetiche em cima das coisas concretas, a mercadoria enfeitiçada, inclusive nossos próprios corpos, nossa saúde, enfim, as coisas mais básicas da vida são apreendidas hoje pela ótica do mercado. Como resistência a esse fenômeno, propomos a ideia de uma estética da existência refletida, no lugar de um mundo de ilusões, que se possa articular à ideia de gosto pela vida concreta: gosto pela vida em sua concretude, a partir do que ela nos oferece e nos tira. Não podemos conceber uma experiência ética separada de uma estética, no sentido de que, em primeiro lugar, precisamos aceitar e visualizar nossa condição de animal social, pois dependemos uns dos outros, estamos todos no mesmo planeta e precisamos dele também. O horror da condição de dependentes uns dos outros nos faz perder de vista o justamente o caráter ético da vida em conjunto. E se pararmos de recusá-la e pudermos tratá-la com bom gosto?

Falo a partir do meu percurso pela psicanálise, que começa, no que diz respeito à teoria, com a leitura do texto A questão da análise leiga, no qual são abordadas questões sobre quem pode ou não se tornar psicanalista - questão de 
poder, de campo, domínio e lei. Foucault, trazendo essas questões a partir de uma análise crítica das instituições, ou seja, pela via do domínio em nome da razão, do biopoder etc., me forneceu as chaves para cuidar da minha formação no sentido de manter uma formação rigorosa, mas que não perdesse a fertilidade, a capacidade de gerar novas linhas de pensamento, sempre atenta para não cair no engodo de uma pseudoproteção, "garantida" pela "segurança" advinda dos muros conceituais. Lembrando sempre do que Nietzsche diz a respeito de como nos quer a sabedoria: “corajosos, descuidados, zombeteiros, violentos - assim nos quer a sabedoria: ela é uma mulher, ela ama somente um guerreiro". A psicanálise desloca os lugares clássicos do saber principalmente porque parte do princípio de que os saberes se sustentam pelo edifício afetivo de cada um. Assim, ela pode ser vista a partir de um alinhamento com uma perspectiva ética da subjetivação.

Acreditamos ser urgente abrir espaço de reflexão sobre uma política da felicidade vinculada à ideia de atribuir sentido à vida pela via criativa. Essa visão não cabe na concepção de vida pequeno-burguesa, que apreende qualquer objeto como objeto de consumo, que se compra no final de uma cadeia de cuja criação o indivíduo não participa. Muito diferente desse tipo simplificado de experiência, a tarefa com a qual me vi envolvida nesse curso foi a de empreender um trabalho artesanal, pois, como curso, ele oferece um recorte cronológico, algumas indicações, determinadas comparações entre diferentes modos de subjetivação, mas, como em toda a obra de Foucault, precisamos, a partir de nossa singularidade, fabricar nossa própria chave.

Hoje fica mais claro que, para pensarmos a questão do sujeito na nossa época, é necessário abrir espaço para novas relações no âmbito coletivo que, mesmo contando com o apoio do aparato institucional, possam ultrapassar seu modelo, até mesmo para escapar da armadilha de captar as forças humanas para a manutenção do mesmo aparato - espaço de aposta na vida, de ver aquilo que não pode ser descartado: que estar vivo gera angústia e que é a partir dessa angústia que encontramos o motor que pode vir a criar as coisas.

Esta tese pretendeu dar forma a pontos de vista, angústias, linhas de pensamento, saberes e não saberes, enfim, a elementos os mais variados dentro da ideia de dar forma a determinados aspectos da vida, apostando sempre em uma estética da existência. 


\section{Referências bibliográficas}

ARAÚJO, Inês Lacerda. Foucault e a crítica do sujeito. Curitiba: Editora da UFPR, 2001.

BIRMAN, Joel. Entre cuidado e saber de si: sobre Foucault e a psicanálise. Rio de Janeiro: Relume Dumará, 2000.

CASTRO, Edgardo. Vocabulário de Foucault. Belo Horizonte: Autêntica, 2009.

DEBORD, Guy. A sociedade do espetáculo: comentários sobre a sociedade do espetáculo. Tradução de Estela dos Santos Abreu. Rio de Janeiro: Contraponto, 1997.

DREYFUS, H.; RABINOW, P. Michel Foucault. Beyond structuralism and hermeneutics. Chicago: Chicago Press, 1982.

. Michel Foucault, un parcours philosophique. Au delà de l'objectivité et de la subjectivité. Paris: Gallimard, 1984.

. Michel Foucault, uma trajetória filosófica. Para além do estruturalismo e da hermenêutica. Rio de Janeiro: Forense Universitária, 1995.

ERIBON, Didier. Michel Foucault: 1926-1984. São Paulo: Companhia das Letras, 1990.

. Michel Foucault e seus contemporâneos. Rio de Janeiro: Zahar, 1996.

EWALD, François. Um poder sin un afuera. In: DELEUZE, G.; BALBIER, E. Michel Foucault, filósofo. Barcelona: Gedisa, 1999.

FOUCAULT, Michel. Les Mots et les choses. Paris: Gallimard, 1966.

. L'Archéologie du savoir. Paris: Gallimard, 1969.

. L'Ordre du discours. Leçon inaugurale au Collège de France prononcée le 2 décembre 1970. Paris: Gallimard, 1971.

. Histoire de la folie à l'Âge Classique. Paris: Gallimard, 1972.

. Surveiller et punir: naissance de la prison. Paris: Gallimard,1975.

. Histoire de la sexualité I: la volonté de savoir. Paris: Gallimard,1976.

. Histoire de la sexualité II: l'usage des plaisirs. Paris: Gallimard, 1984a.

. Histoire de la sexualité III: le souci de soi. Paris: Gallimard, 1984b.

. As palavras e as coisas: uma arqueologia das ciências humanas. Tradução

de Salma Tannus Muchail. 7. ed. São Paulo: Martins Fontes, 1995. 
. A arqueologia do saber. Tradução de Luiz Felipe Baeta Neves. 5. ed. Rio de Janeiro: Forense Universitária, 1997a.

. Resumo dos cursos do Collège de France (1970-1982). Tradução de Andréa Daher. Rio de Janeiro: Zahar, 1997b.

. Microfísica do poder. Tradução de vários. Organização, introdução e revisão técnica de Roberto Machado. 13. ed. Rio de Janeiro: Graal, 1998.

. A verdade e as formas jurídicas. Tradução de Roberto Machado e Eduardo Jardim Morais. 2. ed. Rio de Janeiro: Nau, 1999a.

. Em defesa da sociedade: curso no Collège de France (1983-1984).

Tradução de Maria Ermantína Galvão. 1. ed. São Paulo: Martins Fontes, 1999b.

. História da loucura na Idade Clássica. Tradução de José Teixeira Coelho.

6. ed. São Paulo: Perspectiva, 1999c.

. História da sexualidade I: a vontade de saber. Tradução de Maria Thereza da Costa Albuquerque e José Augusto Guilhon de Albuquerque. 12. ed. Rio de Janeiro: Graal, 1999d.

A ordem do discurso: aula inaugural no Collège de France. Tradução de Laura Fraga de Almeida Sampaio. 6. ed. São Paulo: Loyola, 2000.

. L'Herméneutique du sujet. Cours au Collège de France 1981-1982. Paris: Seuil/Gallimard, 2001a.

. Dits et écrits (1954-1988). Paris: Gallimard, 2001b. (Coleção Quarto).

. Ditos e escritos I: problematização do sujeito: psicologia, psiquiatria e psicanálise. Organização e seleção de textos de Manoel Barros da Motta. Tradução de Vera Lucia Avellar Ribeiro. 2. ed. Rio de Janeiro: Forense Universitária, 2002a. . Vigiar e punir: nascimento da prisão. Tradução de Raquel Ramalhete. 26. ed. Petrópolis: Vozes, 2002b.

A hermenêutica do sujeito. Curso no Collège de France (1981-1982).

Tradução de Marcio Alves da Fonseca e Salma Tannus Muchail. São Paulo: Martins Fontes, 2006a.

Ditos e escritos V: ética, sexualidade, política. Organização e seleção de textos de Manoel Barros da Motta. Tradução de Elisa Monteiro e Inês Autran Dourado Barbosa. 2. ed. Rio de Janeiro: Forense Universitária, 2006b.

Ditos e escritos IV: estratégia, poder-saber. Organização e seleção de textos de Manoel Barros da Motta. Tradução de Vera Lucia Avellar Ribeiro. 2. ed. Rio de Janeiro: Forense Universitária, 2006c. 
História da sexualidade II: o uso dos prazeres. Tradução de Maria Thereza da Costa Albuquerque e José Augusto Guilhon de Albuquerque. 7. ed. Rio de Janeiro: Graal, 2006d.

. História da sexualidade III: o cuidado de si. Tradução de Maria Thereza da Costa Albuquerque e José Augusto Guilhon de Albuquerque. 9. ed. Rio de Janeiro: Graal, 2007.

Ditos e escritos II: arqueologia das ciências e história dos sistemas de pensamento. Organização e seleção de textos de Manoel Barros da Motta. Tradução de Elisa Monteiro. 2. ed. Rio de Janeiro: Forense Universitária, 2008.

. O governo de si e dos outros. Curso no Collège de France (1982-1983).

Tradução de Eduardo Brandão. 1. ed. São Paulo: Martins Fontes, 2010a.

. Ditos e escritos VI: repensar a política. Organização e seleção de textos de Manoel Barros da Motta. Tradução de Ana Lúcia Paranhos Pessoa. 1. ed. Rio de Janeiro: Forense Universitária, 2010b.

. A coragem da verdade: o governo de si e dos outros II. Curso no Collège de France (1975-1976). Tradução de Eduardo Brandão. 1. ed. São Paulo: Editora Martins Fontes, 2011a.

. Os anormais. Curso no Collège de France (1974-1975). Tradução de Eduardo Brandão. 2. ed. São Paulo: Martins Fontes, 2011 b.

. Aulas sobre a vontade de saber. Curso no Collège de France (1970-1971).

Tradução de Rosemary Costhek Abílio. 1. ed. São Paulo: Martins Fontes, 2014a.

Ditos e escritos IX: genealogia da ética, subjetividade e sexualidade.

Organização, seleção de textos e revisão técnica de Manoel Barros da Motta. Tradução de Abner Chiquieri. 1. ed. Rio de Janeiro: Forense Universitária, 2014b. FREUD, Sigmund. Obras completas XVIII. Tradução de Paulo César de Souza. São Paulo: Companhia das Letras, 2010.

. Obras completas IX. Tradução de Paulo César de Souza. São Paulo:

Companhia das Letras, 2013.

. Obras completas XVII. Tradução de Paulo César de Souza. São Paulo:

Companhia das Letras, 2014.

GROS, Frédéric. Michel Foucault. Paris: PUF, 1996.

. Foucault et la folie. Paris: PUF, 1997.

(Org.). Foucault: le courage de la vérité. Paris: PUF, 2002. 
(Org.). Foucault: a coragem da verdade. Tradução de Marcos Marcionilo.

São Paulo: Parábola, 2004.

O cuidado de si em Michel Foucault. In: RAGO, Margareth; VEIGA-

NETO, Alfredo (Orgs.). Figuras de Foucault. São Paulo: Autêntica, 2006.

GOLDMAN, Márcio. Objetivação e subjetivação no último Foucault. In:

CASTELO BRANCO, G; BAETA NEVES, L. F. (Orgs.). Michel Foucault: da arqueologia do saber à estética da existência. Rio de Janeiro: Nau; Londrina: Cefil, 1998.

GRONDIN, Jean. Introdução à hermenêutica filosófica. Tradução de Benno Dischinger. São Leopoldo: Unisinos, 1999.

HADOT, Pierre. Reflexiones sobre la noción de "cultivo de si mismo". In:

DELEUZE, G.; BALBIER, E. Michel Foucault, filósofo. Barcelona: Gedisa, 1999.

JAEGER, Werner. Paideia: a formação do homem grego. Tradução de Artur M.

Parreira. São Paulo: Martins Fontes, 2013.

JUNIOR, Durval Muniz de Albuquerque et al. Cartografias de Foucault. Belo Horizonte: Autêntica, 2008.

KANT, Immanuel. Crítica da razão pura. São Paulo: Abril Cultural, 1974.

. “O que é esclarecimento?”. In: Kant: textos seletos. Petrópolis:

Vozes, 1985.

MACHADO, Roberto. Ciência e saber: a trajetória da arqueologia de Foucault. Rio de Janeiro: Graal, 1982.

Foucault, a filosofia e a literatura. Rio de Janeiro: Zahar, 2000.

MAIA, Antônio. A questão da Aufklärung: mise au point de uma trajetória. In: CASTELO BRANCO, G.; PORTOCARRERO, V. (Orgs.). Retratos de Foucault. Rio de Janeiro: Nau, 2000.

- Deleuze leitor de Foucault: elementos para uma crítica da cultura contemporânea. In: RAGO, Margareth; VEIGA-NETO, Alfredo (Orgs.). Figuras de Foucault. São Paulo: Autêntica, 2006.

LACAN, Jacques. O eu na teoria de Freud e na técnica da psicanálise. Rio de Janeiro: Zahar, 1985. Escritos. Tradução de Vera Ribeiro. Rio de Janeiro: Zahar, 1998.

MARTON, Scarlett. Foucault leitor de Nietzsche. In: RIBEIRO, Renato Janine (Org.). Recordar Foucault - os textos do Colóquio Foucault. São Paulo: Brasiliense, 1985. 
MARTON, Scarlett. Nietzsche, um "francês" entre franceses. São Paulo: Barcarolla; Discurso, 2009.

MARX, Karl. Manuscritos econômico-filosóficos. Tradução, apresentação e notas de Jesus Ranieiri. 1. ed. São Paulo: Boitempo, 2010.

. O capital: crítica da economia política. Livro I: O processo de produção do capital. Tradução de Rubens Enderle. 1. ed. São Paulo: Boitempo, 2013.

NIETZSCHE, Friedrich. Além do bem e do mal: prelúdio a uma filosofia do futuro. Tradução, notas e posfácio de Paulo César de Souza. São Paulo: Companhia das Letras, 1992.

. Genealogia da moral: uma polêmica. Tradução, notas e posfácio de Paulo César de Souza. São Paulo: Companhia das Letras, 1998.

A gaia ciência. Tradução, notas e posfácio de Paulo César de Souza. São Paulo: Companhia das Letras, 2001.

Crepúsculo dos ídolos, ou Como se filosofa com o martelo. Tradução e notas de Paulo César de Souza. São Paulo: Companhia das Letras, 2006.

Assim falou Zaratustra: um livro para todos e para ninguém. Tradução, notas e posfácio de Paulo César de Souza. São Paulo: Companhia das Letras, 2011. ORTEGA, Francisco. Amizade e estética da existência em Foucault. Rio de Janeiro: Graal, 1999.

PORTOCARRERO, Vera. Foucault: a história dos saberes e das práticas. In: (Org.). Filosofia, história e sociologia das ciências: abordagens contemporâneas. Rio de Janeiro: Fiocruz, 1994.

Representação e constituição do objeto na modernidade. In: CASTELO BRANCO, G.; PORTOCARRERO, V. (Org.). Retratos de Foucault. Rio de Janeiro: Nau, 2000.

. Práticas sociais de divisão e constituição do sujeito. In: RAGO, Margareth; VEIGA-NETO, Alfredo (Orgs.). Figuras de Foucault. São Paulo: Autêntica, 2006. RAJCHMAN, John. Foucault: a liberdade da filosofia. Rio de Janeiro: Zahar, 1987.

REVEL, Judith. Le Vocabulaire de Foucault. Paris: Ellipses, 2002.

. Michel Foucault: expériences de la pensée. Paris: Bordas, 2005.

. Dictionnaire Foucault. Paris: Ellipses, 2008.

RIBEIRO, Renato Janine. O discurso diferente. In: (Org.). Recordar Foucault - os textos do Colóquio Foucault. São Paulo: Brasiliense, 1985. 
SILVEIRA, Nise da. Imagens do inconsciente. Brasília: Alhambra, 1981.

VAZ, Paulo. Um pensamento infame: história e liberdade em Michel Foucault. Rio de Janeiro: Imago, 1992.

VEYNE, Paul. Le Dernier Foucault et la morale. Critique, Paris, n. 471-472, ago.set. 1986.

Como se escreve a história e Foucault revoluciona a história. Brasília: $\mathrm{UnB}, 1998$.

. Foucault y la superación (o remate) del nihilismo. In: DELEUZE, G.; BALBIER, E. Michel Foucault, filósofo. Barcelona: Gedisa, 1999.

. Foucault: seu pensamento, sua pessoa. Rio de Janeiro: Civilização Brasileira, 2011. 